DOE/RL-99-83

Revision 7

\title{
Environmental Management Performance Report August 2000
}

\section{RECORD COPY}

Prepared for the U.S. Department of Energy

Assistant Secretary for Environmental Management

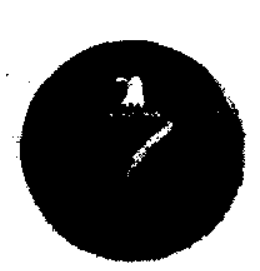

\author{
United States \\ Department of Energy \\ Richland Operations Office \\ P.O. Box 550 \\ Richland, Washington 99352
}

Approved for Public Release; Further Dissemination Unlimited 


\section{Environmental Management Performance Report August 2000}

www. hanford.gov/empr/toc. htm

\section{RECORD COPY}

Prepared for the U.S. Department of Energy

Assistant Secretary for Environmental Management

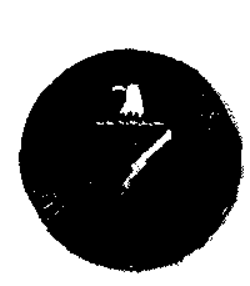

\section{United States}

Department of Energy

Richland Operations Office

P.O. Box 550

Richland, Washington 99352

Approved for Public Release; Further Dissemination Unlimited 


\section{TRADEMARK DISCLAIMER}

Reference herein to any specific commercial product, process, or service by trade name, trademark, manufacturer, or otherwise, does not necessarily constitute or imply its endorsement, recommendation, or favoring by the United

States Government or any agency thereof or its contractors or subcontractors.

This report has been reproduced from the best available copy. Available in paper copy and microfiche.

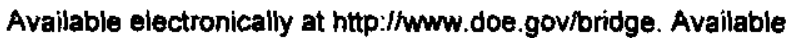
for a processing fee to the U.S. Department of Energy and its contractors, in paper, from:

U.S. Department of Energy

Office of Scientific and Technical Information

P.O. Box 62

Oak Ridge, TN 37831-0062

phone: 865-576-8401

fax: 865-576-5728

email: reports@adonis.osti.gov(423) 576-8401

Available for sale to the public, in paper, from:

U.S. Department of Commerce

National Technical Information Service

5285 Port Royal Road

Springfield, VA 22161

phone: 800-553-6847

fax: 703-605-6900

email: orders. ntis,fectworld.gov

online ordering: http:/hwww.ntis.gov/ordering.htm

Printed in the United States of Americe

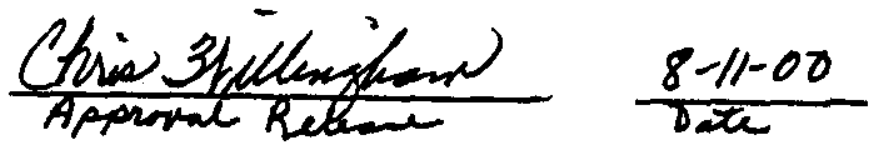




\section{INTRODUCTION}

The purpose of the Environmental Management Performance Report (EMPR) is to provide the Department of Energy Richland Operations Office's (DOE-RL's) report of Hanford's Environmental Management (EM) performance by:

- Project Hanford Management Contract (PHMC) through Fluor Hanford, Inc. (FH) and its subcontractors,

- Environmental Restoration Contract through Bechtel Hanford, Inc. (BHI), and its subcontractors,

- Pacific Northwest National Laboratories (PNNL) for Science and Technology support to the EM Mission, and

- Office of Safety Regulation of the TWRS Privatization Contractor.

This report is a monthly publication that summarizes EM Site performance under RL Operations Office. It is organized by the four sections listed above, with each section containing an Executive Summary and Area Performance Summaries. A glossary of terms is provided at the end of this report for reference purposes.

The report date on the cover reflects the month in which the report is released. 


\section{Project Hanford Management Contractor}

Environmental Management Performance Report to

\section{DOE Richland Operations Office August 2000}

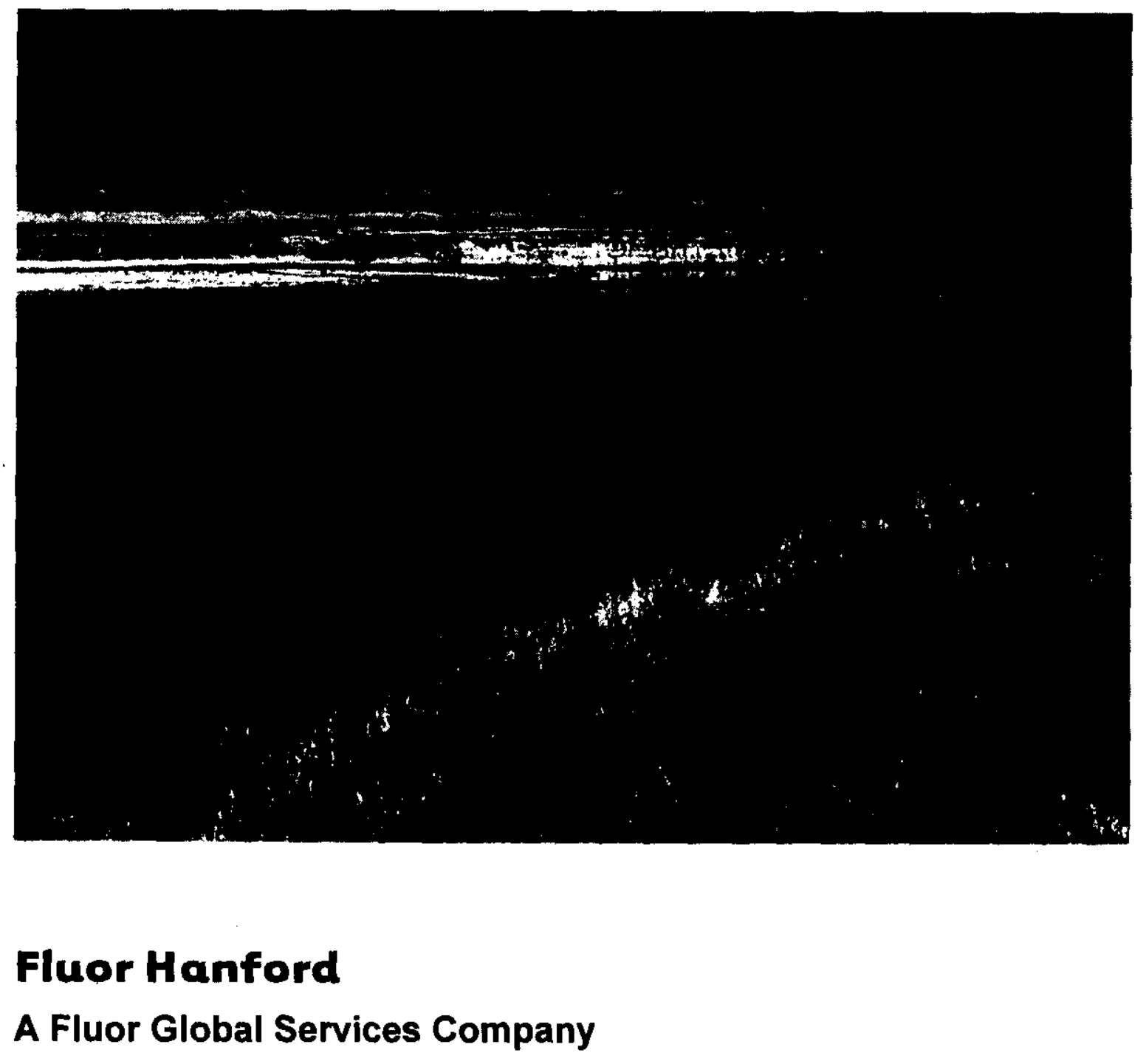




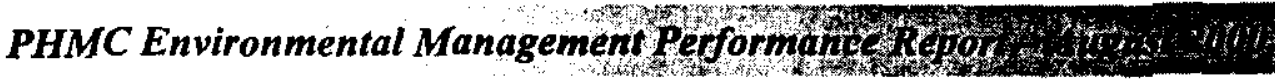

\section{Table of Contents}

Section

Executive Summary A

The Plateau

Waste Management. B: 1

Analytical Services (222-S, HASP, WSCF) B: 2

Nuclear Material Stabilization. C: 1

\section{The River}

River Corridor C: 2

Spent Nuclear Fuel

Advanced Reactors Transition E

EM - 50 Science \& Technology Activities F

\section{The Future}

HAMMER G

\section{Multiple Outcomes}

Landlord. H

Support ....................................................................................................... I

National Programs................................................................................... J 


\section{INTRODUCTION}

$\mathrm{T}$ he purpose of this report is to provide the Department of Energy Richland Operations Office (DOE-RL) a monthly summary of the Project Hanford Management Contractor's (PHMC) Environmental Management (EM) performance by Fluor Hanford (FH) and its subcontractors. In addition to project-specific information, it includes some PHMC-level data not detailed elsewhere in the report.

Section A, Executive Summary, provides an executive level summary of the cost, schedule, and technical performance described in this report. It summarizes performance for the period covered, highlights areas worthy of management attention, and provides a forward look to some of the upcoming key performance activities as extracted from the PHMC baseline.

The remaining sections provide detailed performance data relative to each individual Project (e.g., Waste Management, Spent Nuclear Fuels, etc.), in support of Section A of the report. Unless otherwise noted, the Safety, Conduct of Operations, Metrics, and Cost/Schedule data contained herein is as of June 30,2000 . All other information is updated as of July 24, unless otherwise noted. 


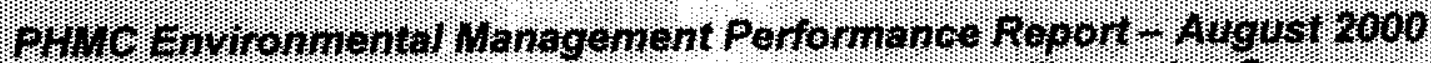

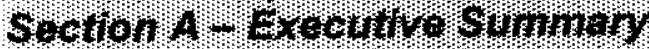
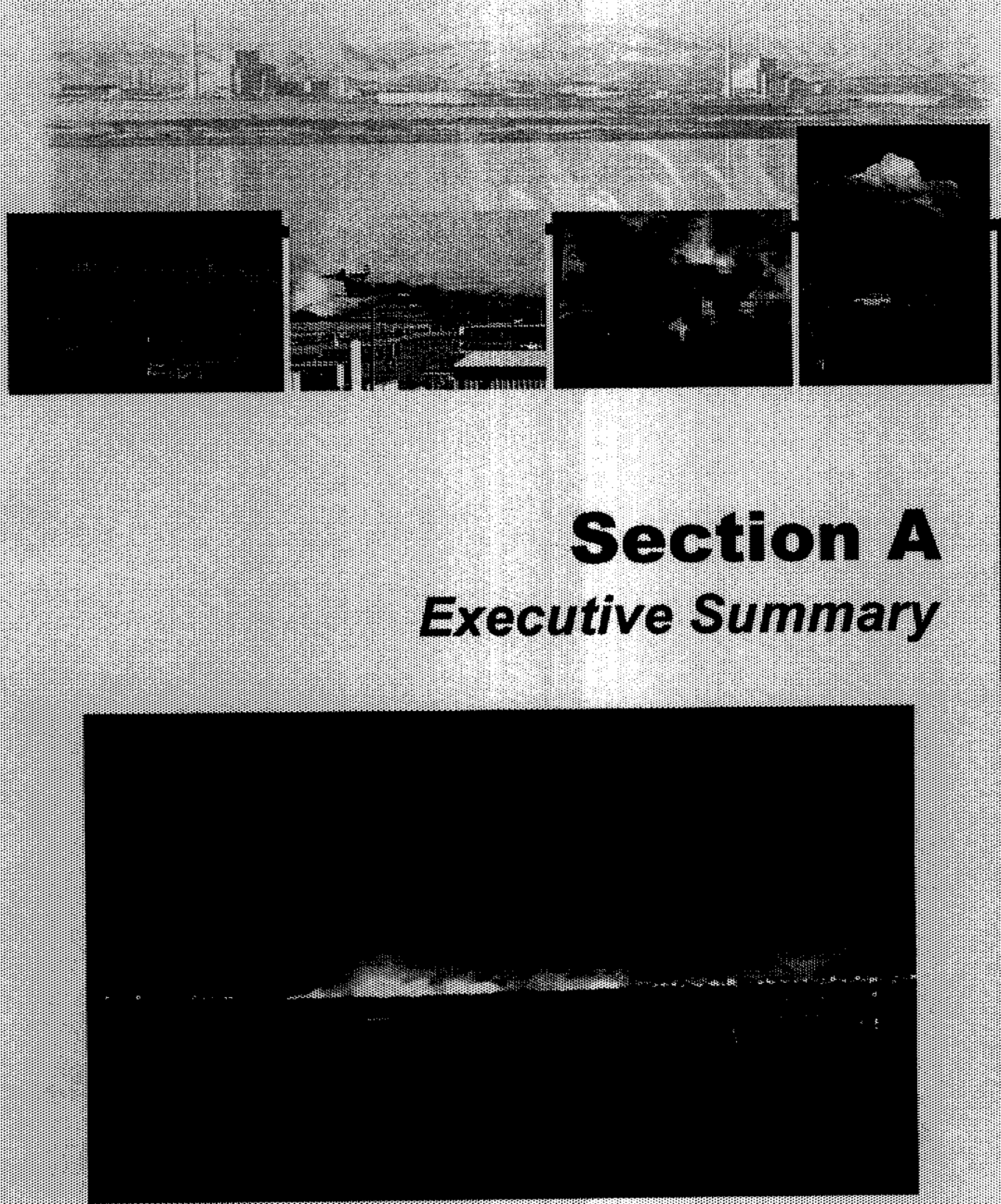


\section{INTRODUCTION}

This section provides an executive level summary of the performance information covered in this report and is intended to bring to Management's attention that information considered to be most noteworthy. All cost, schedule, milestone commitments, performance measures, and safety data is current as of June 30 . Accomplishments, Issues and Integration items are current as of July 24 unless otherwise noted.

The section begins with a description of notable accomplishments that have occurred since the last report and are considered to have made the greatest contribution toward safe, timely, and costeffective clean up. Following the accomplishment section is an overall fiscal year-to-date summary analysis addressing cost, schedule, and milestone performance. Overviews of safety ensue. The next segment of the Executive Summary, entitled Critical Issues, is designed to identify the high-level challenges to achieving cleanup progress.

The next section includes FY 2000 EM Management Commitment High Visibility Project Milestones and Critical Few Performance Measures.

The Key Integration Activities section follows next, highlighting PHMC activities that cross contractor boundaries and demonstrate the shared value of partnering with other Site entities to accomplish the work. Concluding the Executive Summary, a forward-looking synopsis of Upcoming Planned Key Events is provided.

\section{NOTABLE ACCOMPLISHMENTS}

- The first shipment of Hanford transuranic waste left for the Waste Isolation Pilot Plant (WIPP) on July 12, 2000. The shipment was received at WIPP on July 14, 2000 and unloaded with no issues reported.

- The Remote-Handled TRU Project Management Plan (PMP) was completed on June 29, 2000, satisfying TPA milestone M-91-03, which was due June 30, 2000.

- As of July 13,2000 a total of 317 cans of Plutonium oxides and sludges have been stabilized through thermal stabilization ( 27 additional items since last report).

- The closeout activities for the B Plant transfer to the Environmental Restoration Contractor (Bechtel Hanford, Inc.) were completed 10 days ahead of the Washington State Department of Health (WDOH) due date of July $28,2000$.

- All seventeen 324 B Cell grout containers scheduled for shipment this fiscal year have now been shipped to the Low-level Burial Grounds in the 200 Area. Shipment of this waste is critical to meeting TPA milestone M-89-02, "Complete Removal of 324 Building Radiochemical Engineering Cell (REC) B Cell Mixed Waste (MW) and Equipment," due November 2000.

- The third and fourth shipments of Multi-Canister Overpacks (MCOs) were received from Joseph Oat, Inc. ahead of schedule. A total of $32 \mathrm{MCO}$ save been received at the Hanford Site as of July $14,2000$. 
- The River Corridor Project and other Fluor Hanford projects successfully completed the Integrated Safety Management System Phase II Verification following a multi-facility review led by the U.S. Department of Energy (DOE), Richland Operations Office (RL).

\section{Performance Data and Analysis}

The following provides a brief synopsis of overall PHMC Environmental Management (EM) cost, schedule, and milestone performance.

\section{FY 2000 Cost and Schedule Performance}

Cost Performance - Fiscal-year-to-date (FYTD) cost performance reflects a one percent ( $\$ 4.8$ million) unfavorable cost variance that is within the established $+10 /-5$ percent threshold.

Schedule Performance - There is a FYTD five percent ( $\$ 20.2$ million) unfavorable schedule variance that is at the established $+10 /-7.5$ percent threshold. 


\section{Baseline Performance Status \\ FY 2000 Cost / SChedule Performance - All Fund TyPes Cumulative to Date Status (\$M)}

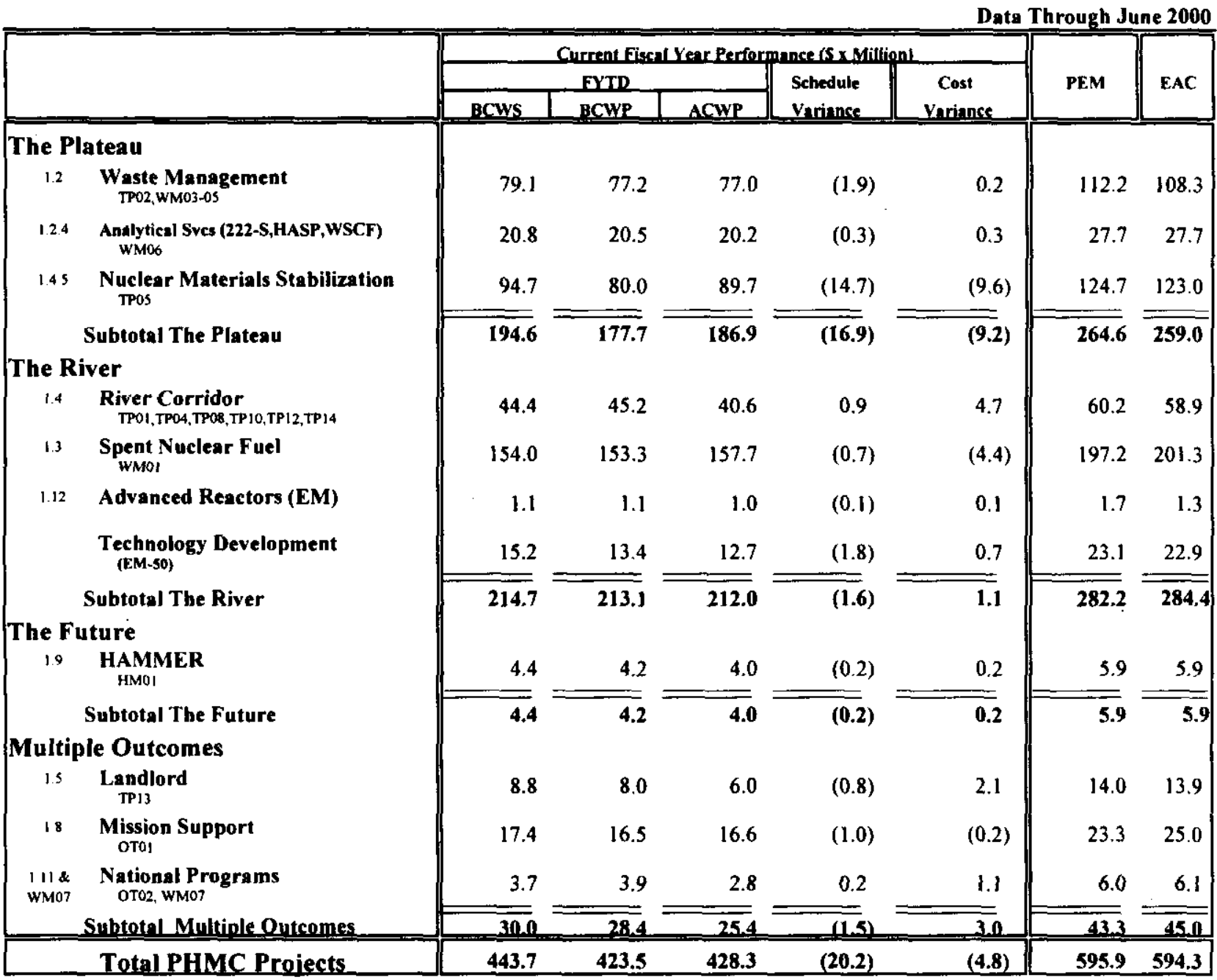

Notes: Column headings (BCWS, BCWP, FYSF, EAC, etc.) are defined in the glossary at the end of the report. Calculations are based on Project Baseline Summary detail. Waste Management, Analytical Services, River Corridor, and Nuclear Materials Stabilization have included RLDirected costs (e.g. steam and laundry) in the PEM BCWS. Advanced Reactors (EM) have included steam. Technology Development does not include ORP/RPP TTPs currently reported in the RL Dataset in the HQ-IPABS-PEM.

Funds Management - Although earned value measures are currently close to or within established thresholds, the PHMC is currently projecting a potential overrun in the Project Completion Control Point. Project Fiscal Year Spend Forecast (FYSF) data continues to be analyzed in comparison to available funds, and recent trends indicate that without continued action, costs could exceed funds. Management has taken aggressive steps designed to correct this situation and preliminary data indicate that the actions are making significant contributions toward cost reductions. In addition, an internal reprogramming package was submitted that transfers \$5M from the Post 2006 control point to the Project Completion control point. This transfer will help 
balance the cost problem between the control points, but will not totally resolve the overall funds management problem. The PHMC will monitor costs very closely and it is expected the issue will be resolved by fiscal year end.

\section{FUNDS AVAILABILITY VS. SPENDING FORECAST (\$M) (FLUOR HANFORD, INC. ONLY)}

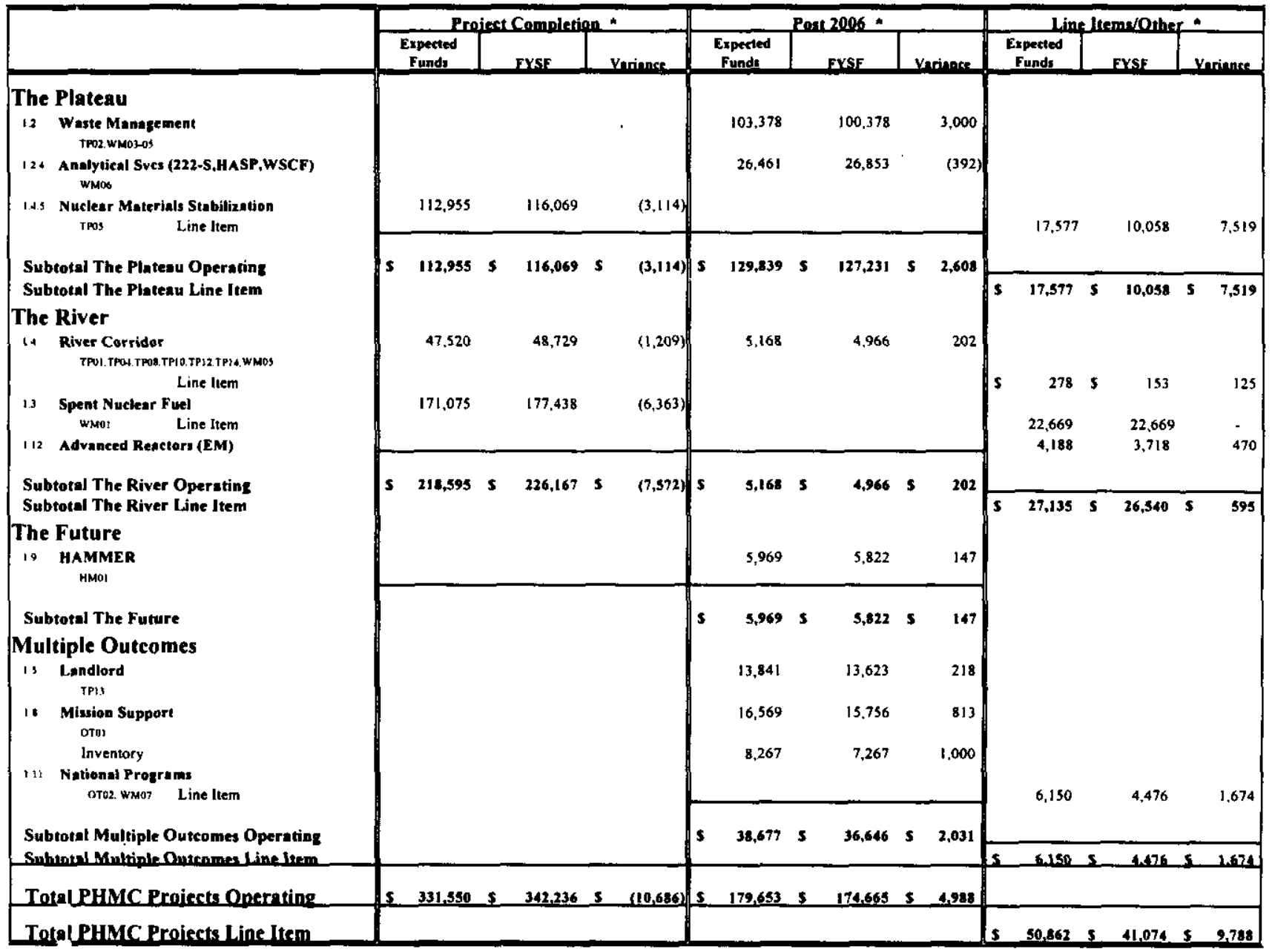

* Control Point

The above chart depicts data presented to RL on July 28, 2000. Funds management splits WM05 between River Corridor and Waste Management, and TP12 between River Corridor and Nuclear Materials Stabilization.

Note: As of July, a \$5 million internal reprogramming from a RPP Line Item and other Post 2006 funds to the Project Completion control point has been approved by DOE-HQ, and will be implemented in the August financial plan. 
The following Cost/Schedule and Variance to Plan chart provides an overall graphical view of fiscal year to date performance and cost and schedule performance indicators.

\section{fy 2000 Cost / Schedule Performance Cumulative to Date Status}

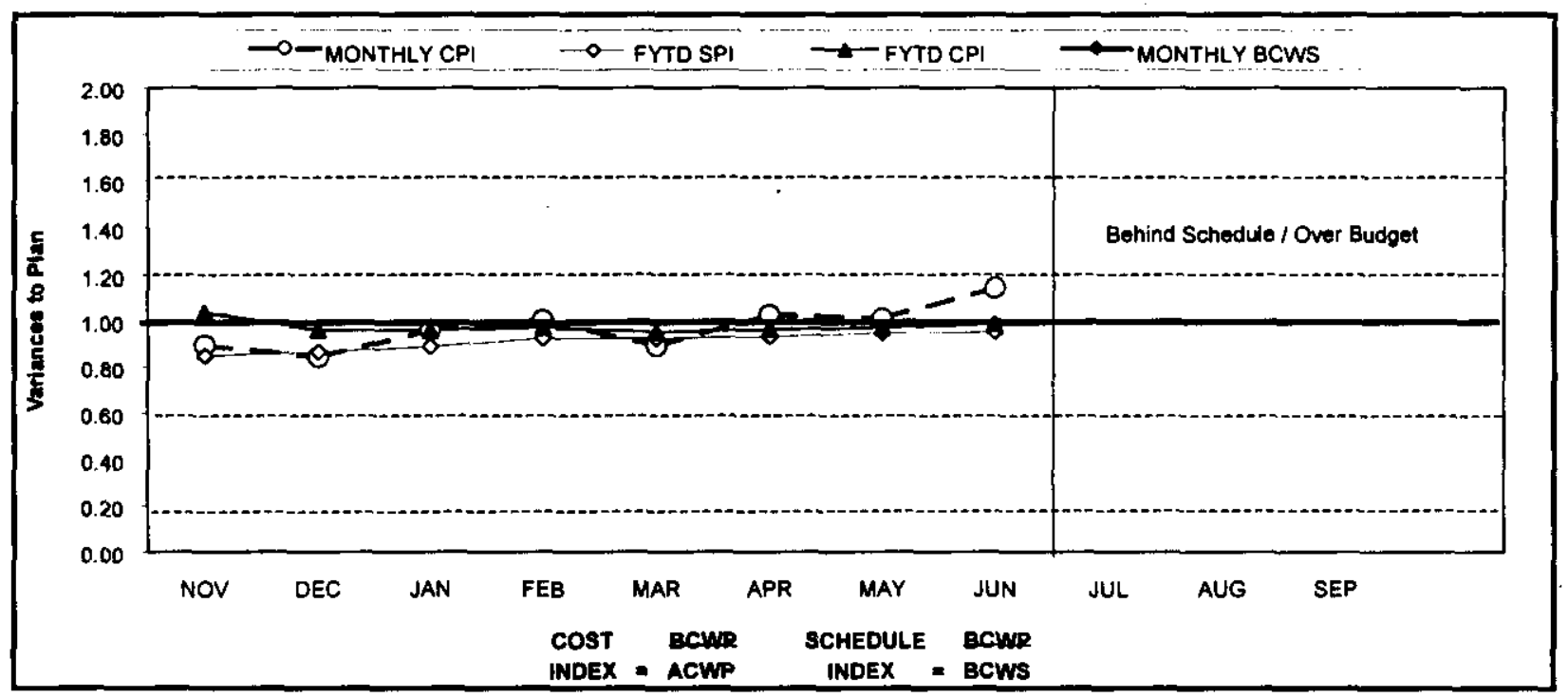

\begin{tabular}{|c|c|c|c|c|c|c|c|c|c|c|c|c|}
\hline FY 20,00 & OCT & NOV & DEC & JAN & FER & MAR & APR & MAY & JiN & Jul & AUG & SEP \\
\hline MONTHLYSPL & 090 & 0.82 & 0.90 & 0.95 & 106 & 0.97 & 0.97 & 1.04 & 100 & & & \\
\hline MONTHLY CPL & 1.36 & 0.90 & 0.84 & 0.96 & 100 & 0.89 & 103 & 101 & 4.1. & & & \\
\hline EYTD SPL & 0,90 & 0.85 & 0.87 & 0.89 & 093 & 092 & 0.93 & 0.95 & 0.95 & & & \\
\hline FYTD CPL & 130 & 104 & 0,96 & 0.96 & 0.97 & 0.95 & 0.26 & 0.97 & 0.99 & & & \\
\hline MONTHLYACWS & $5 \quad 32,549$ & $5 \quad 53.749$ & 43.002 & 46.580 & 47.280 & 59.420 & 51.912 & 61.994 & 46,499 & 44,301 & 55,003 & 52.946 \\
\hline MONTHLY BCWP & 529438 & 543.853 & 38.748 & $5 \quad 44.295$ & 50.297 & $5 \quad \$ 4,698$ & 50.587 & 64610 & $5 \quad 46.292$ & & & \\
\hline MONTHIY LACWP & $5 \quad 21.598$ & 549006 & $5 \quad 45.973$ & $5 \quad 46,037$ & $5 \quad 50.745$ & $5 \quad 61.462$ & $5 \quad 49,200$ & $5 \quad 63.799$ & s $\quad 40,480$ & & & \\
\hline FYTD BCWS & $5 \quad 32.549$ & 5.86 .298 & $5 \quad 129.299$ & $5 \quad 175.880$ & $5.223,860$ & 5283.280 & $5 \quad 335.193$ & 5. 397.187 & $5 \quad 443.686$ & $5 \quad 487.987$ & s 542.990 & $5 \quad 595.936$ \\
\hline EYTDACWP & $5 \quad 29.438$ & $5,23,202$ & 5112.049 & $5 \quad 156,244$ & 1.207 .291 & $s \quad 261.900$ & $5 \quad 212.577$ & s. 372187 & s. 423,478 & & & \\
\hline FYTD ACWP & $5 \quad 21.598$ & 570.604 & 5116.577 & $5 \quad 162.614$ & is 213,399 & S. 274.821 & s. 324,021 & 5 387820 & $5 \quad 428.301$ & & & \\
\hline
\end{tabular}

\section{Milestone Performance}

Milestones represent significant events in project execution. They are established to provide a higher level of visibility to critical deliverables and to provide specific status about the accomplishment of these key events. Because of the relative importance of milestones, the ability to track and assess milestone performance provides an effective tool for managing the PHMC EM cleanup mission.

FYTD milestone performance (Enforceable Agreement [EA], U.S. Department of EnergyHeadquarters [DOE-HQ], and RL) shows that 45 of 59 (76 percent) approved baseline milestones were completed on or ahead of schedule, 7 milestones (12 percent) were completed late, and 7 milestones (12 percent) are overdue. The seven overdue milestones are associated with two projects: Nuclear Material Stabilization-six and River Corridor-one. These overdue milestones do not share a common cause. 
In addition to the FY2000 milestones described above, there are four overdue milestones from the prior fiscal year (FY1999). Further details regarding these milestones may be found in the Project Sections.

FY 2000 information is depicted graphically below and on the following page. For additional details related to the data in the graphs and prior year milestones, refer to the relevant project section titled "Milestone Exception Report."

FY 2000 information reflects the current approved baseline. Changes in both the number and type of milestones from month to month are the result of Baseline Change Requests (BCRs) approved during the year.

\begin{tabular}{|c|c|c|c|c|c|c|c|c|}
\hline \multirow[b]{2}{*}{ MILESTONE TYPE } & \multicolumn{4}{|c|}{ FISCAL YEAR-TO-DATE } & \multicolumn{3}{|c|}{ REMAINING SCHEDULED } & \multirow[b]{2}{*}{$\begin{array}{c}\text { TOTAL } \\
\text { FY } \\
2000 \\
\end{array}$} \\
\hline & $\begin{array}{c}\text { Completed } \\
\text { Early }\end{array}$ & $\begin{array}{c}\text { Completed } \\
\text { On } \\
\text { Schedule } \\
\end{array}$ & $\begin{array}{c}\text { Completed } \\
\text { Late }\end{array}$ & Overdue & $\begin{array}{c}\text { Forecast } \\
\text { Early }\end{array}$ & $\begin{array}{c}\text { Forecast On } \\
\text { Schedule }\end{array}$ & $\begin{array}{c}\text { Forecast } \\
\text { Late }\end{array}$ & \\
\hline Enforceable Agreement & 22 & 4 & 0 & 0 & 0 & 7. & $\underline{0}$ & 33 \\
\hline DOE-HQ & 0 & 0 & 0 & 1 & 0 & 3 & $\underline{0}$ & 4 \\
\hline$\quad \mathbf{R}$ & 13 & 6. & 7 & 6 & 0 & 37 & $\underline{0}$ & 69 \\
\hline Total Project & 35 & 10 & 7 & 7 & 0 & 47 & 0 & 106 \\
\hline
\end{tabular}

\section{Total Project}

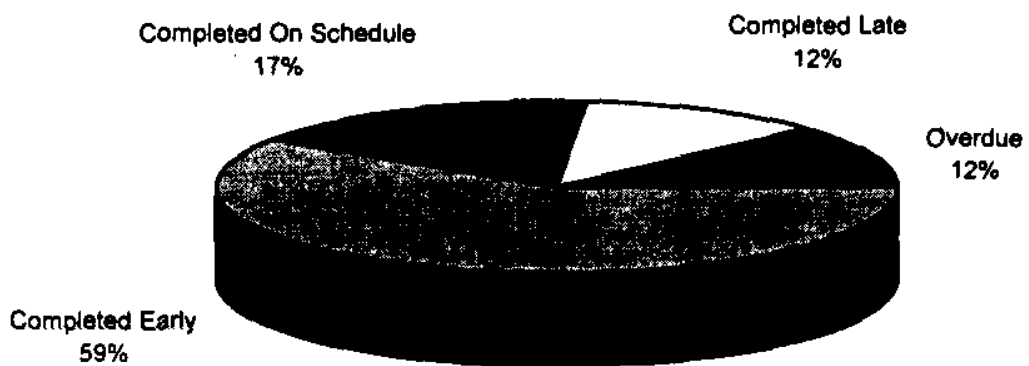

RL

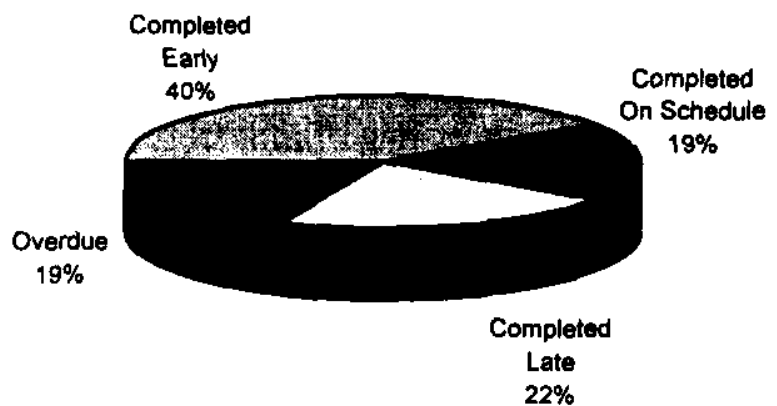

Enforceable Agreement

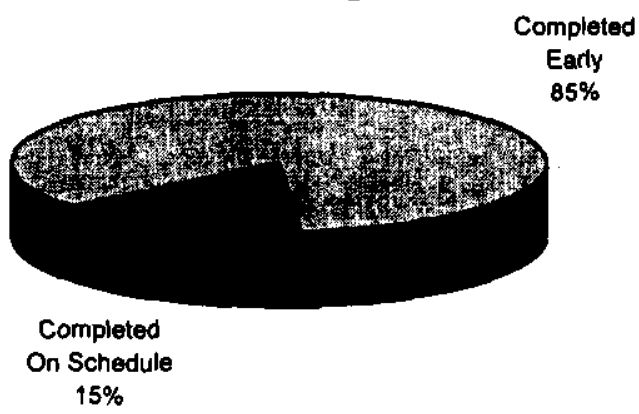


MILESTONE EXCEPTIONS
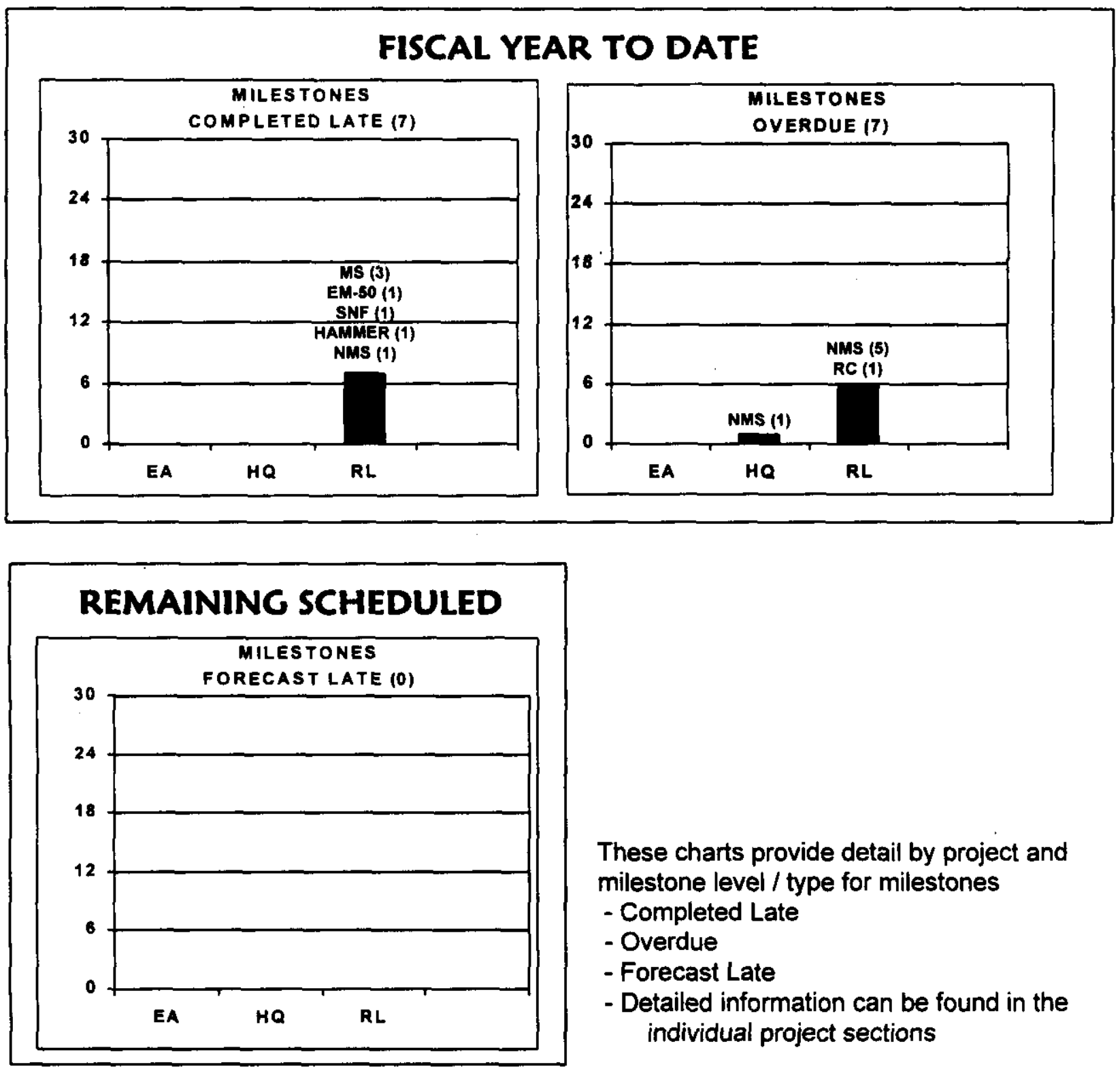

These charts provide detail by project and milestone level / type for milestones

- Completed Late

- Overdue

- Forecast Late

- Detailed information can be found in the individual project sections 


\section{SAFETY OVERVIEW}

The focus of this section is to document trends in occurrences. Improvements in these rates are due to the efforts of the PHMC workforce as they implement the Integrated ES\&H Management System (ISMS), work towards achieving Voluntary Protection Program (VPP) "star" status, and accomplish work through Enhanced Work Planning (EWP). Safety and health statistical data is presented in this section.

\section{Significant Safety and Health EVENTS}

Rates have been stable for over two years. This safety performance plateau has been recognized by the safety organizations, and Fluor Hanford kicked off its Integrated Safety Approach initiative on December 6, 1999 in order to take safety performance to a new level. This initiative focuses on the "people side" of accident prevention. Due to space constraints, FY1996 data is not portrayed on the following graphs.

\section{Total OSHA Recordable Case Rate}

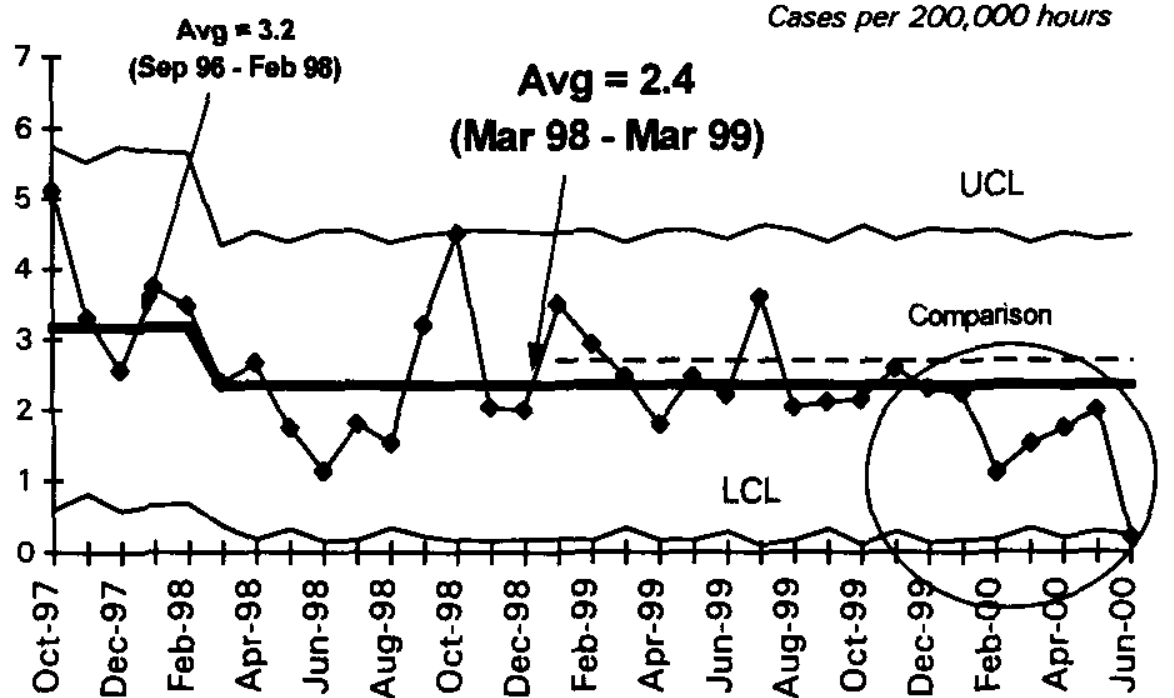

Green
FY $1999=2.6$

FY $2000=1.8$

Contractor Comparison

Average $=2.7(\mathrm{CY} 99)$

The past seven months have been below average, a statistically significant decrease.

FH is implementing a corrective action program to target an OSHA Recordable Case Rate of 0.9. The Fluor Global Services goal is 1.0 . This is in line with Fluor's corporate value of safety and our commitment to the safe clean-up of the Hanford Site.

Six of FH's major projects and service organizations are achieving OSHA Recordable Case Rates of less than 1.0. 


\section{OSHA LOST/RESTRICTED WORKDAY CASE RATE}

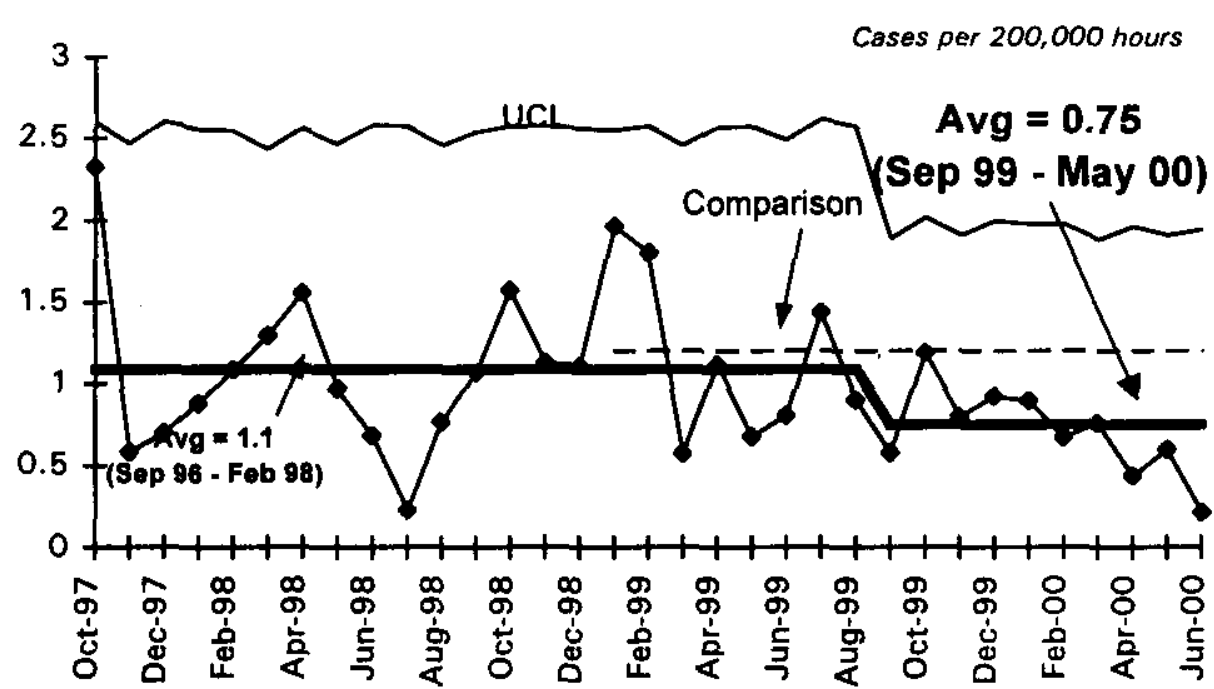

First Aid Case Rate

Cases per 200,000 haurs

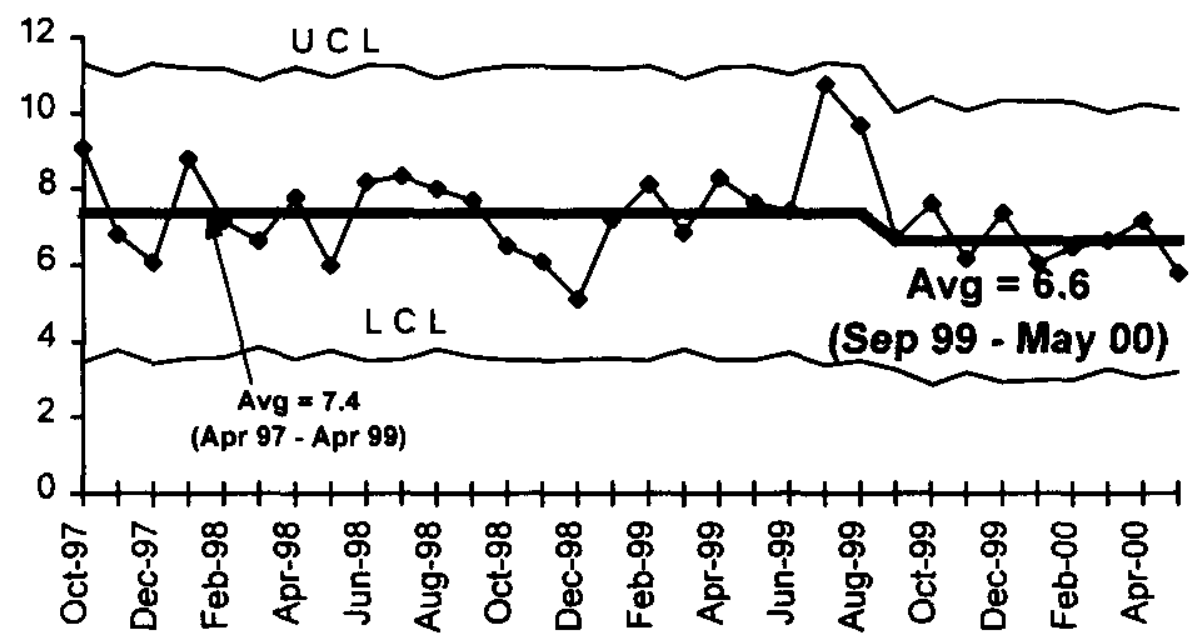

Green

FY $1999=1.1$

FY 2000 to date $=0.71$

Contractor Comparison

Average $=1.2($ CY99)

A new, reduced, average and control limit have been established due to the significant decrease noted last month. Six million hours have been worked since the last lost away workday injury.

\section{Green}

First Aid Rate undergoes seasonal cycles. Increases occur in warmer weather due to insect and animal encounters, and due to wind related minor injuries. First Aid case rate has remained relatively stable, a good indicator that injuries are not being underreported. There are currently 7 months in a row below average, due to the normal winter decrease. 


\section{DOE Safety Cost Index}

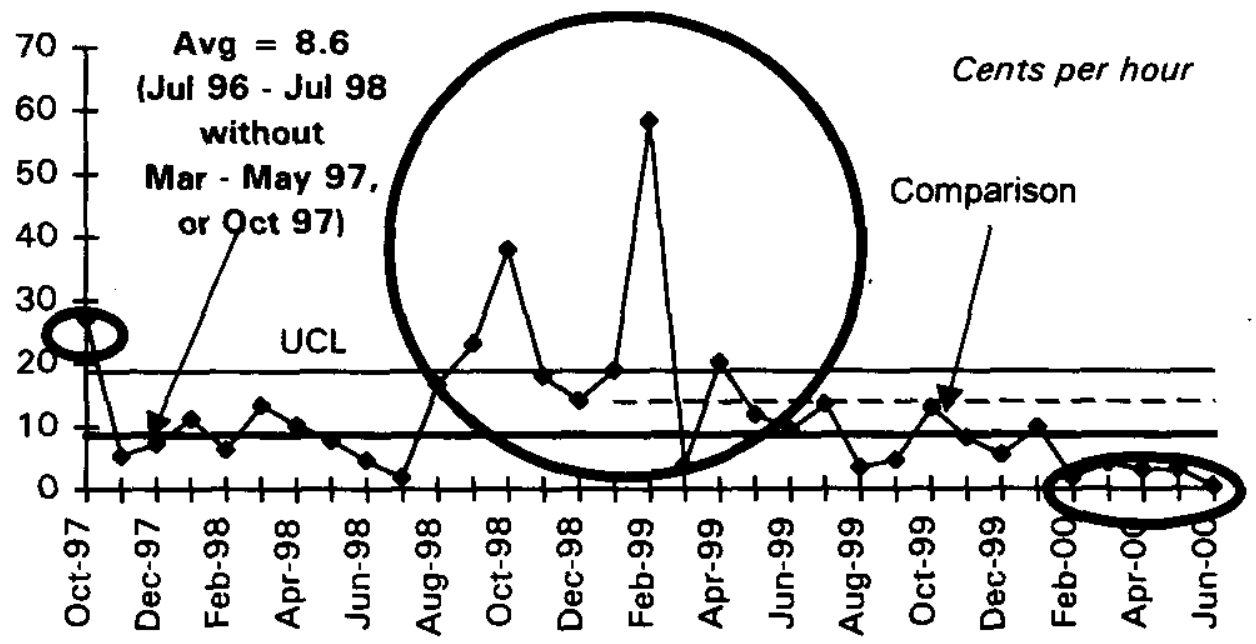

\section{Green}

FY $1999=17$

FY 2000 to date $=\mathbf{5 . 3}$ Contractor Comparison Average $=13.9$ (CY99) There has been a long term cycle over the past three years of decreases for 7 to 9 months, followed by increases. The past five months have been one standard deviation below average. However, recent data may gain further lost or restricted days.

This indicator has been tracked by Fluor Hanford since the beginning of its contract (October 1996). The baseline average was established in 1998, and there has not been a sufficiently stable set of statistical data to change the baseline average since it was initially established.

\section{Critical issues}

On June 27, the Hanford Fire Department (HFD) received a report of a vehicle accident, explosion, and fire on State Route 24. The accident ignited dried weeds/grasses on both sides of the road. With support from the U.S. Fish and Wildlife Service (US F\&WS), DynCorp Heavy Equipment, and Yakima Army Training Center, the HFD deployed all assets to fight the fire.

The fire threatened many facilities and HFD crews concentrated on protecting facilities on the Site.

On July 1 , the fire was officially contained and declared extinguished. Significantly, no major injuries were sustained by the $850+$ firefighters involved in fighting this fire.

A cost estimate was developed and submitted to RL on July 28 that calls for recovery actions over FY2000 and beyond and is estimated to cost $\$ 20.774 \mathrm{M}$. These actions are being further developed. 


\section{EM Corporate Performance Measures}

\begin{tabular}{|c|c|c|c|c|}
\hline Performance Measures & $\begin{array}{c}\text { EN Management } \\
\text { Cormimiment }\end{array}$ & $\begin{array}{c}\text { FY } 2000 \text { Current } \\
\text { Baseline }\end{array}$ & $\begin{array}{l}\text { FYTD } \\
\text { planned }\end{array}$ & $\begin{array}{l}\text { Fxto } \\
\text { Actual }\end{array}$ \\
\hline \multicolumn{5}{|l|}{ Focilitios Deactivated/Decomenissioned } \\
\hline Facilitise deactivated & 21 & 21 & 13 & 25 \\
\hline Facilities deconmuissioned & 13 & 13 & 11 & \\
\hline \multicolumn{5}{|l|}{ TRanuranic oTRULWaste } \\
\hline Stored-totalinventory $\left(\mathrm{m}^{3}\right)$ & 16.333 & 16.316 & 16,323 & 16,372 \\
\hline Disnosed /shipped to DOE site $\mathrm{m}^{3}$ ) & 55 & 55 & 0 & \\
\hline \multicolumn{5}{|l|}{ High Level Waste } \\
\hline Stored-tolal inventory $(\mathrm{m} 3)$ & 4 & 2 & 2 & \\
\hline Treated $\left(\mathrm{m}^{3}\right)$ & 3600 & 3.600 & 3600 & 5,070 \\
\hline \multicolumn{5}{|l|}{ Mixed Low Level Waste } \\
\hline Stored-total inventory (min) & 7.852 & .7852 & 8.178 & 2779 \\
\hline Treated $\left(\mathrm{m}^{3}\right)$ & 1,060 & 1,060 & 810 & 568 \\
\hline Disposed & 835 & 835 & 610 & 301 \\
\hline \multicolumn{5}{|l|}{ Low Lexel Waste } \\
\hline Stored - total inventory $\left(\mathrm{m}^{3}\right)$ & 180 & 180 & 180 & 180 \\
\hline Disposed (on-site commercial) $\left(\mathrm{m}^{3}\right)$ & 6936 & 6,936 & 5.595 & 4.882 \\
\hline \multicolumn{5}{|l|}{ Material Stabilized } \\
\hline Plutonium Oxide (cans) & 400 & 140 & 140 & 307 \\
\hline Plutonium Solution(1) & 255 & 255 & 0 & 13 \\
\hline Plutonium Residue (kg) & 29 & 39 & 0 & \\
\hline Technology Deoloyments & 2 & 9 & 5 & 5 \\
\hline \multicolumn{5}{|l|}{ Pollution Previstion } \\
\hline HAZ MT & 45 & 45 & 45 & 14 \\
\hline SANOMD & 1.781 & 1281 & 1.781 & 775 \\
\hline$L L W(\mathrm{~m} 3)$ & 470 & 470 & .470 & 173 \\
\hline $\mathrm{MLLW}(\mathrm{m} 3)$ & 138 & 138 & 138 & 101 \\
\hline \multicolumn{5}{|l|}{ Cleanun/Stabilized Waste Avoided } \\
\hline BY 2000 planned baseline amount $\mathrm{m}^{3}$ & 1920 & 1920 & 1920 & 4.483 \\
\hline FY 2001 planned baseline amount ( $m$ ) & 1,926 & 1.926 & $N / A$ & $\mathrm{NA}$ \\
\hline
\end{tabular}

All of the above reflect the quarter end status. For deviations $+/-10 \%$, see the following projects sections: Facilities Deactivated (Landlord); HLW Treated, MLLW Treated, MLLW Disposed, LLW Disposed (Waste Management Project); Materials Stabilized, Plutonium Oxide and Solution (Nuclear Materials Stabilization Project). 


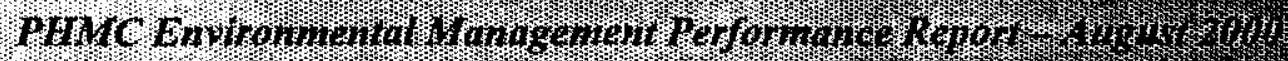

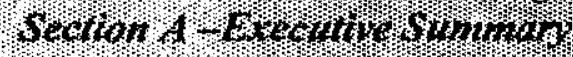

\section{MAnagement Commitment Milestones as of June 30,2000}

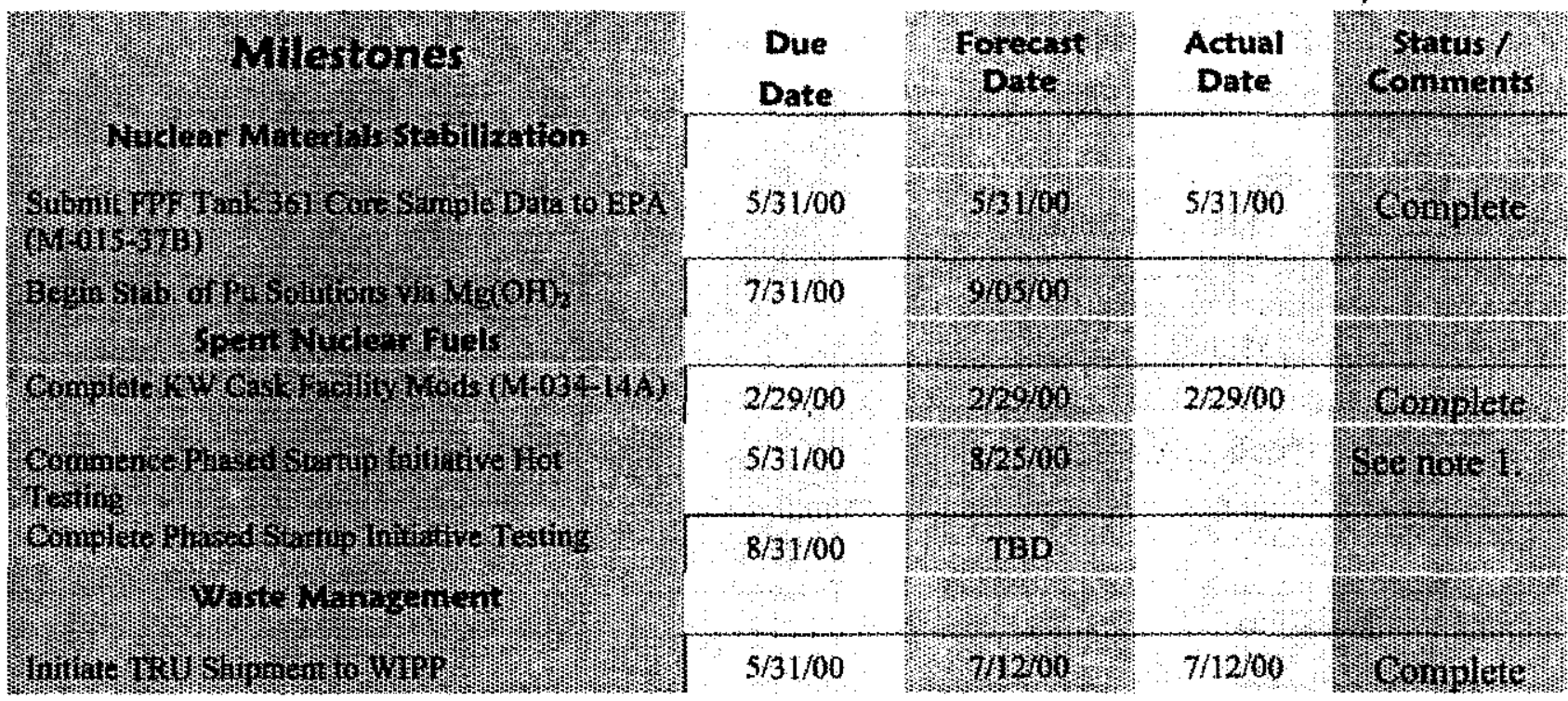

'Increased Management attention has been placed on this due to the delays in completing Phase I and II.

\section{Critical few Performance Measures}

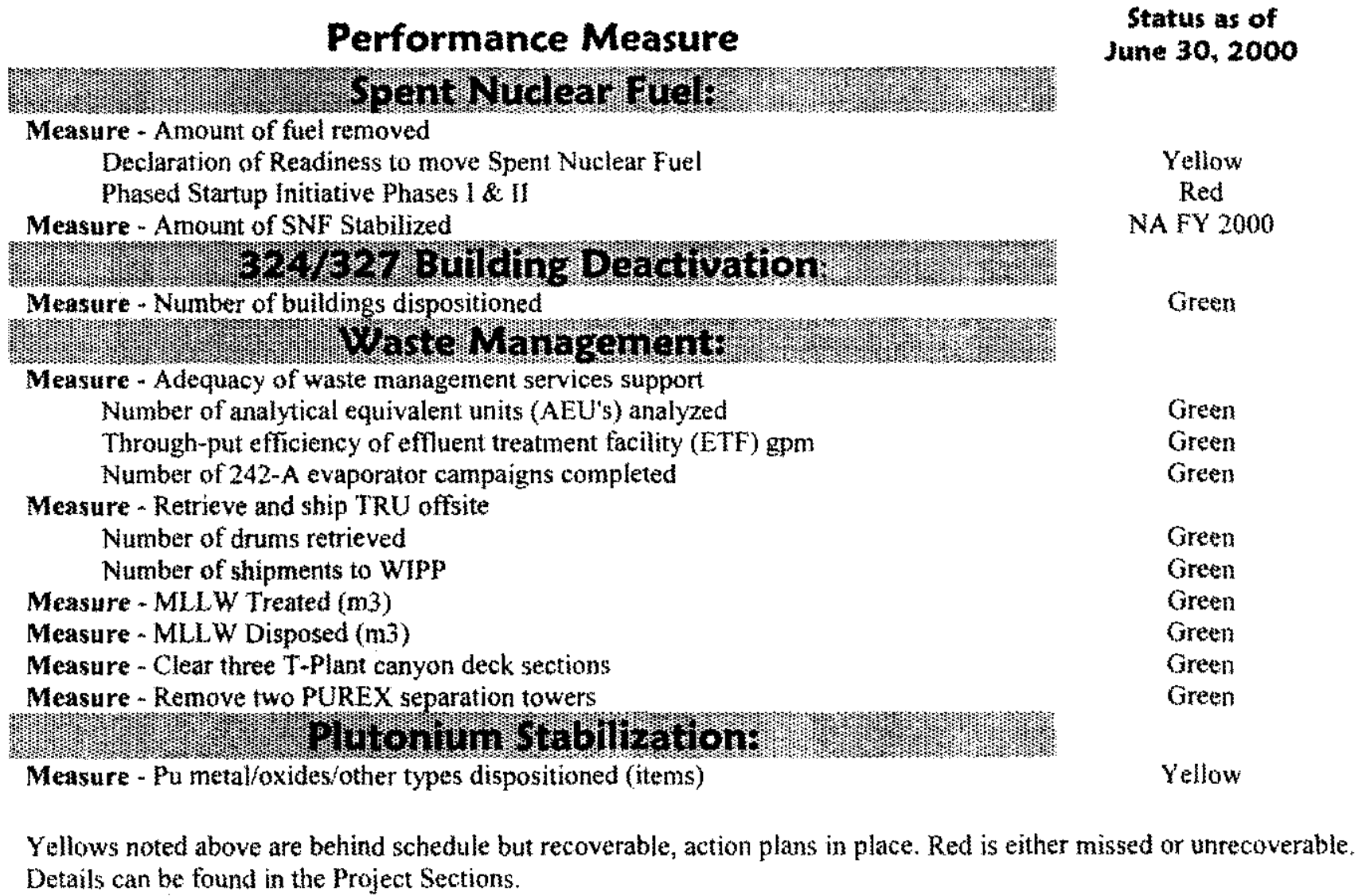




\section{KEY INTEGRATION ACTIVITIES}

7 he following are the key technical integration activities that are currently underway and cross project/contractor lines. These activities are being addressed by inter-discipline and interproject groups and demonstrate that Hanford Site contractors are working together to accomplish the EM Clean up mission.

- Spent nuclear fuel (SNF) final disposition interface activities, including Office of Civilian Radiation Waste Management (OCRWM) Quality Assurance (QA) Program implementation, ongoing with National SNF Program.

- $\quad$ SNF Project fuel removal acceptance criteria and conceptual design reviews for 324 Building (B Cell) ongoing with River Corridor Project.

- $\quad$ K Basins sludge removal and Shippingport (PA) Pressurized Water Reactor Core 2 SNF removal implementation activities ongoing with Waste Management Project.

- WM continues working with DOE-RL, DOE-HQ and other Sites to develop and define Hanford's role in disposing of waste from other sites. Hanford's role as one of the identified LLW/MLLW disposal sites for the Complex is yet to be fully defined.

- WM continues working with PNNL, EM-50 and Mixed Waste Focus Area (MWFA) to obtain funding in support of mixed waste processing.

- Nuclear Material Stabilization Project continues working with PNNL on activities associated with the $\mathrm{Mg}(\mathrm{OH})_{2}$ process in order to accelerate the plutonium solution stabilization process, and polycube stabilization issues (gathering data for the SAR).

- Analytical Services continues to support ORP efforts to establish required analytical support for Waste Treatment Plant (WTP) operations.

- In the longer term, ORP could utilize unused space at WSCF for cold run test support and process laboratory analytical equipment testing.

- $\quad$ The 222-S laboratory, with some refurbishment might become a low cost option to a new large-scale laboratory associated with the WTP.

- A white paper is being prepared for RPP to address the potential support that 222-S and WSCF could provide to the WTP.

- Landlord Project is establishing a Hanford Site Planning Advisory Board made up of cooperating agencies and Tribal representatives to support implementation of the Comprehensive Land Use Plan (CLUP).

- Landlord Project is supporting the RL reality officer in developing and administering Real Estate documents (e.g., licenses, leases, easements, and permits) for both onsite and offsite contractors, agencies such as the U.S. Fish and Wildlife Service. 


\section{Upcoming Planned Key Events}

The following Key events are extracted from the authorized baseline and are currently expected to be accomplished during the next eight months. Most are Enforceable Agreement (EA), HQ or DNFSB Milestones.

\section{Waste Management:}

- Treat 1,160 cubic meters (includes 100 cubic meters stretch) of MLLW at ATG by August 2000; dispose of Land Disposal Restriction compliant waste by September 2000.

- $\quad$ Retrieve 425 drums of suspect TRU waste from the Low-Level Burial Grounds by September 2000.

- $\quad$ Accelerate Readiness to Receive Spent Nuclear Fuel K Basin Sludge.

- $\quad$ Clear three sections of the T Plant Canyon deck in FY 2000.

- $\quad$ Complete entire deck clearing by the end of FY 2001.

\section{Nuclear Materials Stabilization:}

- $\quad$ Begin Pu solution stabilization via $\mathrm{Mg}(\mathrm{OH})_{2}$ in September 2000.

- Complete glovebox installation in July 2000.

- Complete ORR and training activities for stabilization activities in room 230-C in September 2000.

- $\quad$ Continue metal stabilization processing in November 2000.

- Initiate polycube stabilization in 1st quarter of FY 2001.

\section{River Corridor Project:}

- Issue the final report for the 300 Area Waste Acid Treatment System (WATS) Resource Conservation and Recovery Act (RCRA) Closure Activities by September 2000.

- $\quad$ Complete Removal of 324 Building Radiochemical Engineering Cell (REC) B Cell Mixed Waste (MW) and Equipment by November 2000.

\section{Spent Nuclear Fuels:}

- $\quad$ Complete Cask Loadout System (CLS) startup testing by mid-August 2000.

- Complete integrated subsystem testing of the Cold Vacuum Drying facility by the end of August.

- Begin DOE Operational Readiness Review (ORR) for fuel removal by late-September 2000.

- $\quad$ Begin K West Basin fuel removal, drying and storage operations by November 30, 2000.

\section{Landlord}

- $\quad$ Complete Project L-292, Emergency Preparedness Control Station (EPCS) in July 2000. This project retrofits the $100 \mathrm{~K} / \mathrm{D}$ Sirens to the new control system and changes the frequency for all the outdoor Site sirens so they can be controlled from a central point.

- Complete Project L-312, "2101M, MO-235, and Associated Buildings Storm Drainage Resolution" in July 2000. 


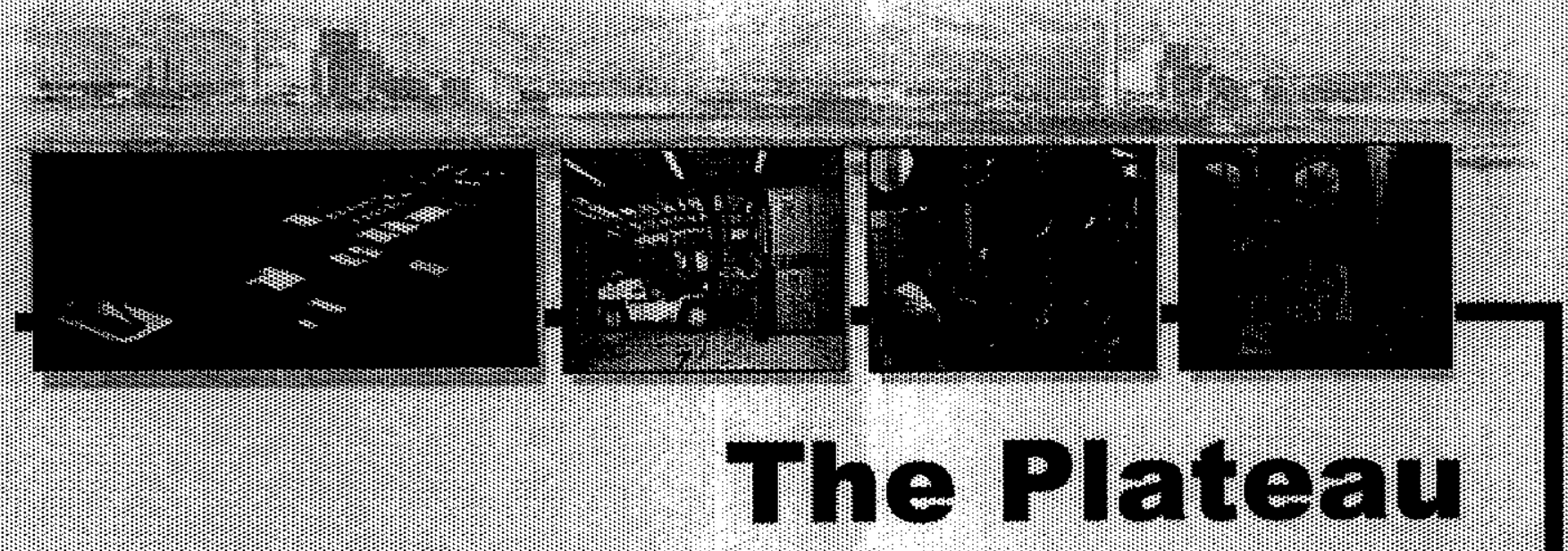

Transition ing the central plateau for long-term waste management Is a key part of the Wanford vision. Betermining the dispostrion of the reanyon. Wacilites, deactivating the Plutonium Finishing Plant and disposing of solid waste are the desired outcomes. prodects included wn The Plateau are Waste Wanagement, Analy tical SeNices. and Nuclear Material Stabilization. 


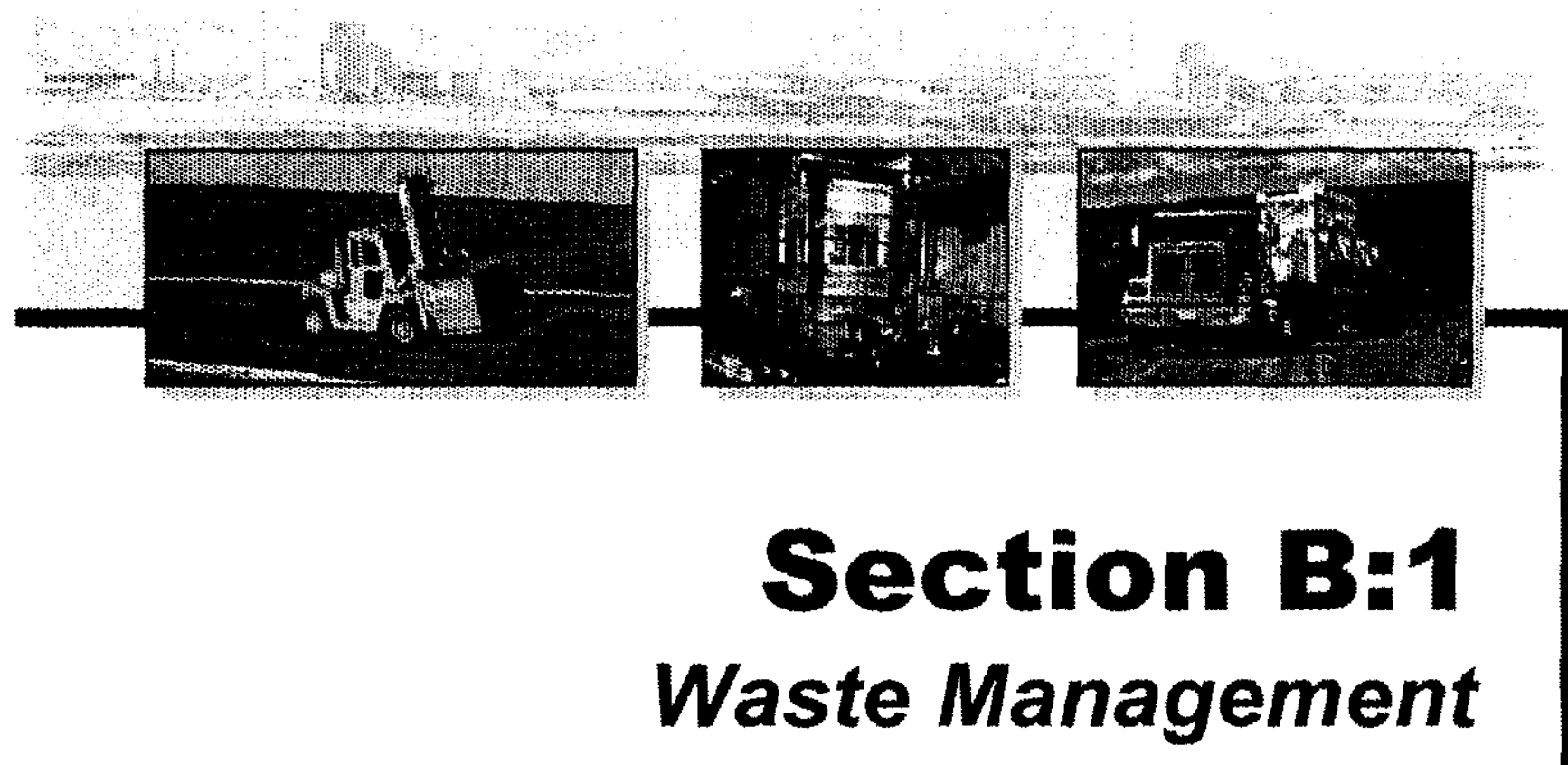

PROJECT MANAGERS

G.H. Sanders, RL (509) 376-6888

E.S. Aromi Jr., WMH

(509) $372-1033$ 


\section{SUMMARY}
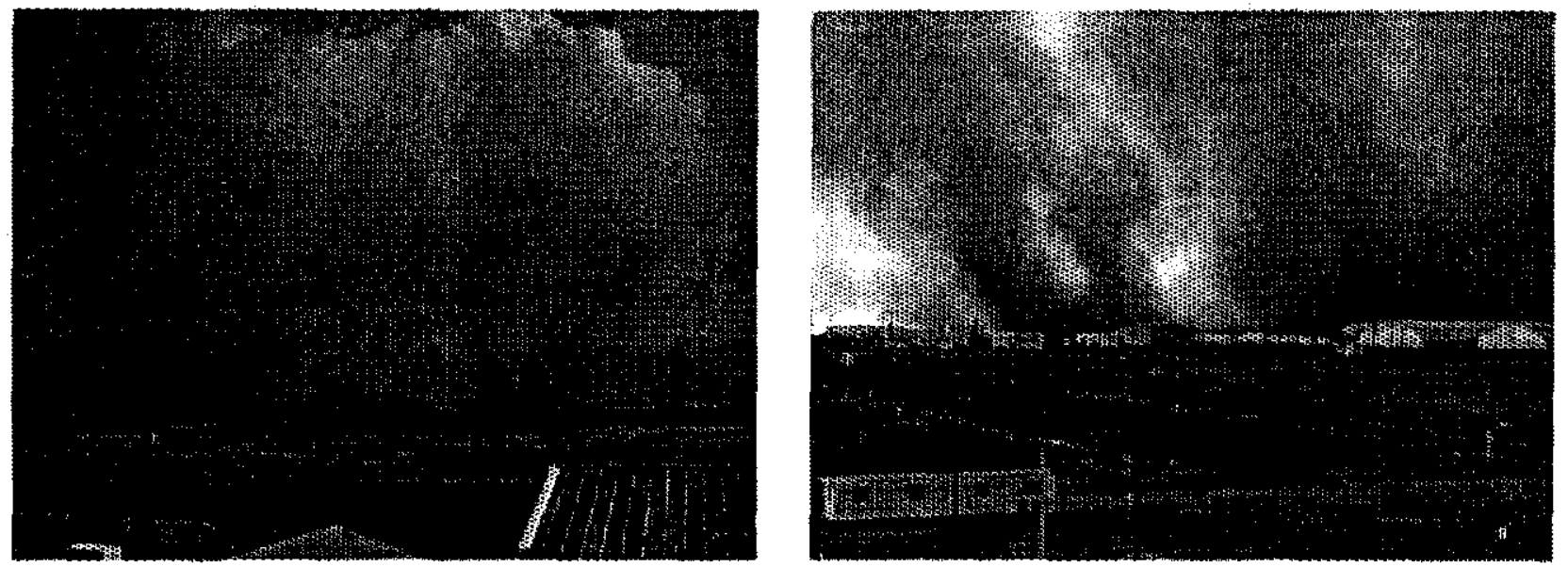

"Work delays of up to 1.5 weeks to various waste management operations in the $200 \mathrm{~W}$ Area resulted from the fire. However, fiscal year end commitments will not be impacted. Potential financial impacts of $\$ 400 \mathrm{~K}$ have been identified."

Waste Management consists of the Solid Waste Storage and Disposal, Project Baseline Summary (PBS) WM03, Work Breakdown Structure (WBS) 1.2.1; Solid Waste Treatment, PBS WM04, WBS 1.2.2; Liquid Effluents - 200 Area, PBS WM05, WBS 1.2.3.1; and the Waste Encapsulation and Storage Facility, PBS TP02, WBS 1.4.2.

PBS WM05 is divided between WBS 1.2.3.1, Liquid Effluents (200 LEF) and WBS 1.2.3.2,310 TEDF/340 Facility ( $300 \mathrm{LEF})$. The $310 \mathrm{TEDF} / 340$ Facility work scope is now included in the River Corridor Project, whereas the Liquid Effluents (200 LEF) work scope has remained in Waste Management. For the purpose of performance analysis, PBS WMOS is reported in its entirety in the Waste Management Project, which has the majority of the work scope and funding.

NOTE: Unless otherwise noted, the Safety, Conduct of Operations, Milestone Achievement, and Cost/Schedule data contained herein is as of June 30,2000. Other data is updated as noted.

Fiscal-year-to-date milestone performance (EA, DOE-HQ and RL) shows that two milestones (100 percent) were completed ahead of schedule. Overall Project performance continues to be excellent. Cost and schedule goals are on track to be met.

\section{ACCOMPLISHMENTS}

- The first shipment of Hanford transuranic waste left for the Waste Isolation Pilot Plant (WIPP) on July 12,2000. The shipment was received at WIPP on July 14, 2000 and unloaded with no issues reported. 
- $\quad$ The Remote-Handled TRU Project Management Plan (PMP) was completed on June 29, 2000, satisfying TPA milestone M-91-03, which was due June 30, 2000.Shipped 870 containers totaling 1,070 cubic meters of mixed low-level waste to Allied Technology Group, Inc. (ATG), which represents 92 percent of the FY 2000 target. This waste volume represents an effective Central Waste Complex (CWC) storage volume reduction of 1,750 cubic meters. ATG has treated 569 cubic meters of waste (FYTD), which represents 49 percent of the FY 2000 treatment target. Hanford has accepted back for disposal, 114 containers totaling 300 cubic meters, which represents 43.2 percent of the FY 2000 disposal target. (Data as of July 19, 2000.)

Waste Receiving and Processing (WRAP) production this reporting period:

- Nondestructive examination of 101 drums

- $\quad$ Nondestructive assays of 128 drums

- On June 23, 2000 during relocation and assay of uncovered suspect TRU waste drums in 218-W-4C Burial Ground Trench 29, it was discovered that more unvented drums exist than had been estimated in the project safety basis. An Unreviewed Safety Question (USQ) was declared and Trench 29 was placed in "Standby" mode. Suspect TRU waste drum relocation and assay in Trench 29 was stopped. Following an analysis of the safety basis relative to the actual number of unvented suspect TRU drums encountered, a Justification for Continued Operation (JCO) in Trench 29 was submitted to DOE-RL on July 18, 2000. DOE-RL approved the JCO and authorized resumption of suspect TRU waste drum relocation and assay operations in Trench 29 on July 20, 2000. Trench 29 was returned to "Operation" mode on July 24, 2000.

Since the last reporting period, processed 3.5 million gallons of wastewater through the 200 Effluent Treatment Facility (through July 20, 2000) supporting River Protection Project (RPP), Environmental Restoration Contract (ERC) 200-UP-1 Groundwater, NBasin Water, Mixed Waste Trench Leachate, and Environmental Restoration Disposal Facility (ERDF) Leachate.

- The three volume "Interim Report for Hanford Land Disposal Restrictions for Mixed Wastes" was delivered to DOE-RL on July 18,2000. The report consists of an Implementation Plan, a Progress Report, and the M-26-01 J Deliverable. The report is now going through the DOE-RL concurrence process so that it can be issued to Ecology by July 31 . Per the Tri-Party Agreement primary document process, Ecology will then have 45 days to review the document and submit comments. certified by Keith Klein on July 13, 2000 and delivered to Ecology on the same day. This met Ecology's corrective action due date specified in the June 12, 2000 Notice of Correction letter.

- T Plant and Burial Ground draft Part B submitted to Ecology on July 7, 2000. 


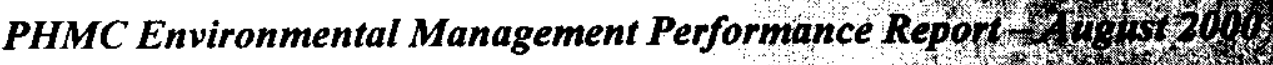

Section B: 1 - Waste Management

\section{Safety}

The project's safety rates are stable. The WMP Safety Council has taken actions to work with the various project safety councils and management to review past events and identify corrective actions.

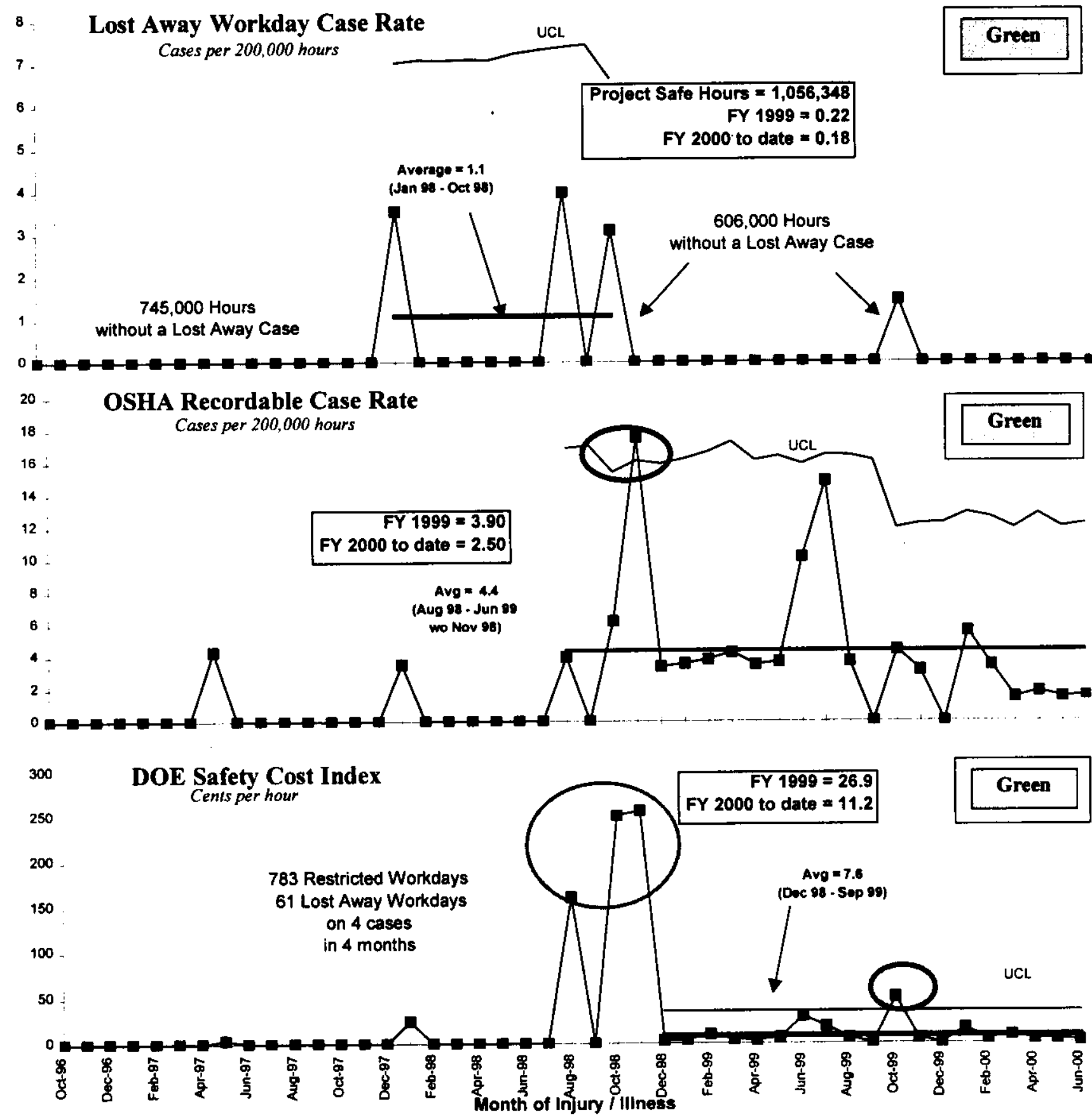




\section{CONDUCT OF OPERATIONS / ISMS STATUS CONDUCT OF OPERATIONS Events per 200,000 hours}

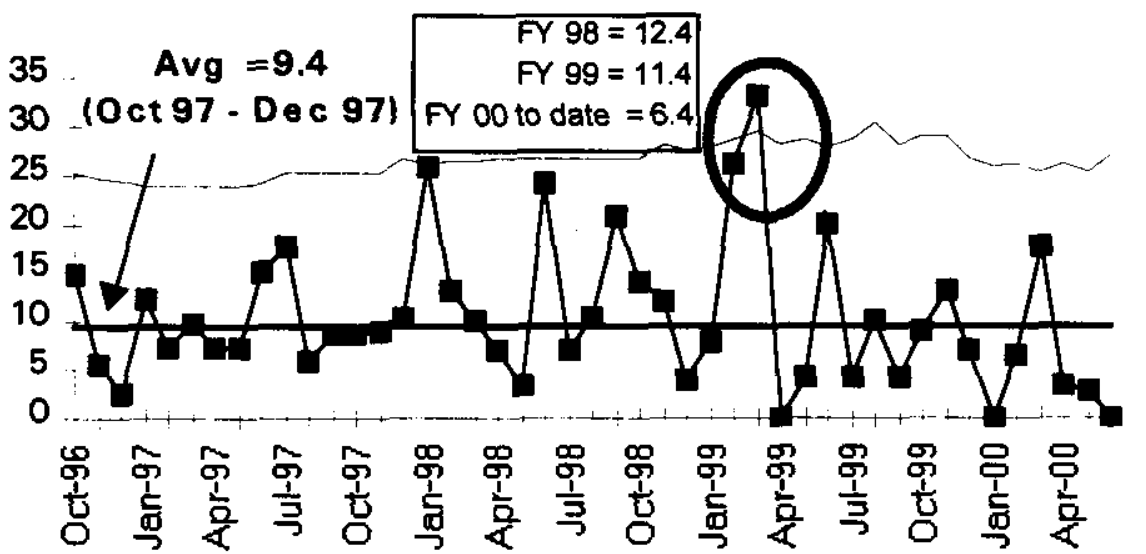

No. of Reports Past 12 Months

18

16

14

12

10

8

6.

4

2 .

ISMS STATUS

Green

Completed Activities:

- Supported successful completion of the Phase II verification of ISMS.

Planned Actions:

- Generate and implement out-year plan to sustain and maintain ISMS effort, including addressing the ten Opportunities for Improvement identified in the Phase II Verification effort.

\section{BREAKTHROUGHS / OPPORTUNITIES FOR IMPROVEMENT}

\section{Breakthroughs}

Green

CAO Project/Treatment Facility: Radiological control techniques were implemented at the Treatment Facility to increase the efficiency of headspace gas sampling operation. Based on the radiological data from sampling over 200 headspace gas samples (no detectable contamination collected on the in-line sample filter), the requirement to use a glove bag over every drum during sampling was eliminated allowing the Treatment Facility Personnel to greatly increase the number of samples collected in a given time. 
Liquid Waste Processing Facility (LWPF) support to ORP: The 200 LWPF prepared a strategy for modifying their permits to begin accepting liquid effluents from the RPP vitrification facility. The strategy identifies the affected permits, the required actions by the PHMC and RPP, and includes a resource-loaded schedule. The strategy provides the basis for our planning input to RPP for out-year support. The strategy was reviewed by Environmental Services who provided valuable input.

\section{Opportunities for Improvement}

Green

Waste and Materials Disposition [except Plutonium (Pu)] Team: RL is assessing the framework under which it can maximize its cleanup while working to incorporate a "realistic" funding profile over the next ten to fifteen years. Consistent with the RL outcomes, the priority is on achieving its River Corridor Outcome by 2010 or shortly thereafter. That necessitates a probable re-sequencing of the current baseline activities in the 200 Areas. The Waste Management Project is leading the Waste and Materials (except Pu) Disposition Team to identify opportunities for improvement.

\section{UPCOMING ACTIVITIES}

WIPP Certification and Waste Shipments - Ramp-up shipment of Hanford TRU waste to the Waste Isolation Pilot Plant (WIPP). Establish recovery path of the NDE/VE data generated prior to the WIPP Permit.

Remote-Handled TRU Project Management Plan (PMP) - Support DOE-RL during the 45day regulator comment period.

MLLW Treatment - Treat 1,160 cubic meters (includes 100 cubic meters stretch) of Mixed Low-Level Waste (MLLW) at Allied Technology Group (ATG) by August 2000; dispose of the Land Disposal Restriction compliant waste by September 2000.

Suspect TRU Waste Retrieval - Retrieve 425 drums of suspect TRU waste from the LowLevel Burial Grounds by September 2000.

Accelerate Readiness to Receive Spent Nuclear Fuel K Basin Sludge - Clear three sections of the T Plant Canyon deck in FY 2000 and complete entire deck clearing by FY 2001.

Complete Project Execution Plan and Conceptual Design Documents for removal of Shippingport Fuel from T Plant in FY 2000.

Land Disposal Restriction Report - Support DOE-RL during the 45-day regulator comment period.

616 Facility Closure - Work to close 616 facility to start in August. 


\section{Cost Performance ( $\$ M)$ :}

\begin{tabular}{|l|c|c|c|}
\hline & BCWP & ACWP & VARIANCE \\
\hline Waste Management & $\$ 77.2$ & $\$ 77.0$ & $\$ 0.2$ \\
\hline
\end{tabular}

The $\$ 0.2$ million (0 percent) favorable cost variance is within the established threshold. Further information at the PBS level can be found in the following Cost Variance Analysis details.

\section{SCHedule Performance (\$M):}

\begin{tabular}{|l|c|c|c|}
\hline & BCWP & BCWS & VARIANCE \\
\hline Waste Management & $\$ 77.2$ & $\$ 79.1$ & $-\$ 1.9$ \\
\hline
\end{tabular}

The $\$ 1.9$ million ( 2 percent) unfavorable schedule variance is within established threshold. Further information at the PBS level can be found in the following Schedule Variance Analysis details.

\section{FY 2000 Cost/Schedule Performance - All Fund Types Cumulative to Date Status - $(\$ 000)$}

\begin{tabular}{|c|c|c|c|c|c|c|c|c|c|c|c|c|c|c|c|c|c|}
\hline \multirow{3}{*}{$\begin{array}{l}\text { PBS WM03 } \\
\text { WBS 1.2.1 }\end{array}$} & \multirow{3}{*}{$\begin{array}{l}\text { By PBS } \\
\text { Solid Waste Storage \& } \\
\text { Disposal }\end{array}$} & \multicolumn{12}{|c|}{ FYTD } & \multirow{2}{*}{\multicolumn{2}{|c|}{ PEM }} & \multirow{2}{*}{\multicolumn{2}{|c|}{ EAC }} \\
\hline & & \multicolumn{2}{|r|}{ BCWs } & \multicolumn{2}{|r|}{ BCWP } & \multicolumn{2}{|c|}{ ACWP } & \multicolumn{2}{|r|}{$\mathbf{S V}$} & \multicolumn{2}{|l|}{$\%$} & cV & $\%$ & & & & \\
\hline & & $\$$ & 25,350 & $s$ & 25,241 & $\$$ & 24,815 & $\$$ & (109) & $0 \%$ & $\mathbf{s}$ & 426 & $2 \%$ & $\mathbf{s}$ & 35,415 & $\mathbf{\$}$ & 34,893 \\
\hline $\begin{array}{l}\text { PBS WM04 } \\
\text { WBS } 1.2 .2\end{array}$ & Solid Waste Treatment & $\$$ & 24,634 & $\$$ & 23,961 & $\$$ & 24,477 & $\$$ & $(672)$ & $-3 \%$ & $\mathbf{s}$ & (515) & $-2 \%$ & $\$$ & 36,073 & $\$$ & 34,595 \\
\hline $\begin{array}{l}\text { PBS WM05* } \\
\text { WBS } 1.2 .3\end{array}$ & $\begin{array}{l}\text { Liquid Effluents - } \\
200 / 300 \text { Area }\end{array}$ & $\$$ & 19,890 & $\mathbf{s}$ & 19,089 & $\$$ & 18,521 & $\$$ & (801) & $-4 \%$ & $\$$ & 567 & $3 \%$ & $\mathbf{S}$ & 28,042 & $\mathbf{S}$ & 26,099 \\
\hline $\begin{array}{l}\text { PBS TP02 } \\
\text { WBS } 1.4 .2\end{array}$ & WESF & $\$$ & 9,203 & $\$$ & 8,923 & $s$ & 9,173 & $\mathbf{S}$ & $(280)$ & $-3 \%$ & $\$$ & $(250)$ & $-3 \%$ & $\$$ & 12,652 & $\$$ & 12,714 \\
\hline & Total & $\mathbf{S}$ & 79,076 & $\$$ & 77,214 & $\mathbf{s}$ & 76,985 & $\$$ & $(1,862)$ & $-2 \%$ & $\$$ & 229 & $0 \%$ & $\$$ & 112,182 & $\$$ & 108,301 \\
\hline
\end{tabular}

- $\quad$ PBS WM05 includes the 300 Area Liquid Effluent, which is part of the River Corridor Project.

- $\quad$ RL-Directed costs (steam and laundry) are included in the Project Execution Module (PEM) BCWS. 


\section{Cost/Schedule Performance Indices (MONTHLY AND FYTD)}

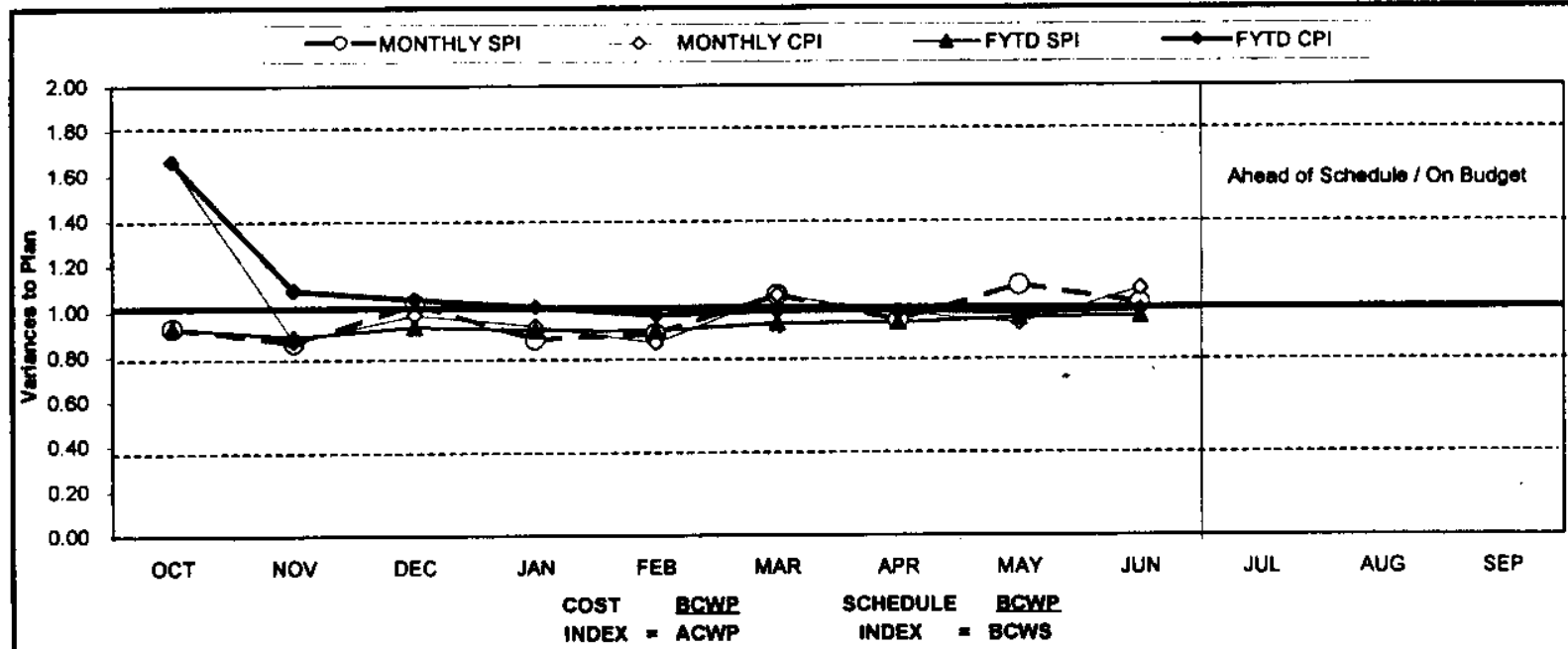

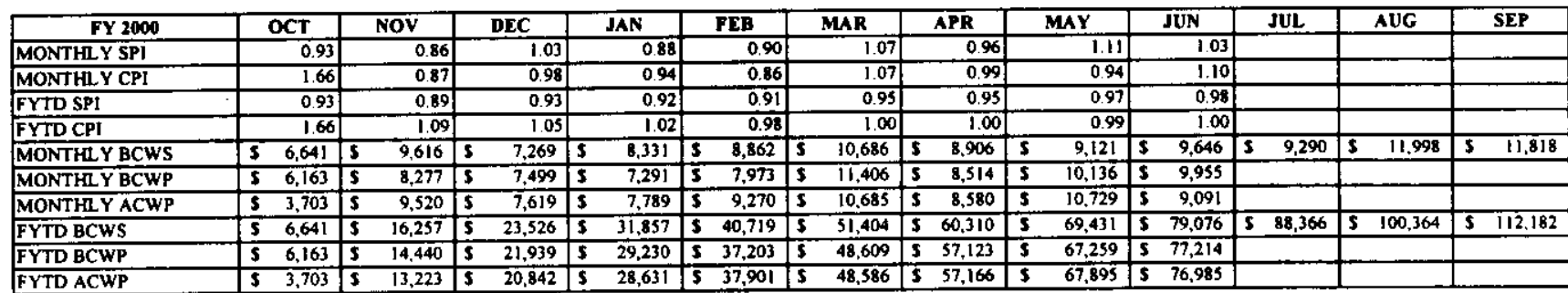

\section{COST VARIANCE ANALYSIS: $(\$ 0.2 \mathrm{M})$}

WBS/PBS

1.2.1/WM03

Solid Waste Storage \& Disposal

Description/Cause: The favorable cost variance of $\$ 0.4 \mathrm{M}$ ( 2 percent) is within the established threshold.

Impact: No impact.

Corrective Action: No action required.

\subsection{2/WM04}

Solid Waste Treatment

Description/Cause: The unfavorable cost variance of $\$ 0.5 \mathrm{M}(2$ percent) is within the established threshold.

Impact: No impact.

Corrective Action: No action required. 
PHMC Environmental Management Performance Report w wh wh, 200

Section B: 1 - Waste Management

\subsubsection{1/WM05 Liquid Effluents}

Description/Cause: The favorable cost variance of $\$ 0.6 \mathrm{M}$ ( 3 percent) is within the established threshold.

Impact: No impact.

Corrective Action: No corrective action required.

1.4.2/TP02

WESF

Description/Cause: The unfavorable cost variance of $\$ 0.3 \mathrm{M}(3$ percent $)$ is within the established threshold.

Impact: No impact.

Corrective Action: No corrective action required.

\section{SCHEDUle VARIANCE ANALYSIS: (-\$1.9M)}

$\underline{\text { WBS/PBS }}$

1.2.1/ WM03

established threshold.

Impact: No Impact.

Corrective Action: No corrective action required.

\subsection{2/ WM04}

Solid Waste Treatment

Description /Cause: The unfavorable schedule variance of $\$ 0.7 \mathrm{M}$ ( 3 percent) is within the established threshold.

Impact: No Impact.

Corrective Action: No corrective action required.

\subsubsection{1/ WM05}

Liquid Effluents

Description /Cause: The unfavorable schedule variance of $\$ 0.8 \mathrm{M}$ (4 percent) is within the established threshold.

Impact: No Impact.

Corrective Action: No corrective action required.

1.4.2/ TP02

WESF

Description /Cause: The unfavorable schedule variance of $\$ 0.3 \mathrm{M}$ ( 3 percent) is within the established threshold.

Impact: No Impact.

Corrective Action: No corrective action required. 


\section{FUNDS MANAGEMENT FUNDS VS SPENDING FORECAST $(\$ 000)$ FY TO DATE THROUGH JUNE 2000 (FLUOR HANFORD, INC. ONLY)}

\begin{tabular}{|c|c|c|c|c|c|c|c|c|c|}
\hline & \multicolumn{3}{|c|}{ Project Completion " } & \multicolumn{3}{|c|}{ Post 2006 * } & \multicolumn{3}{|c|}{ Line ttems * } \\
\hline & $\begin{array}{l}\text { Expoctod } \\
\text { Funde }\end{array}$ & FYSF & Verlance & Expectad Funds & FYSF & Variance & $\begin{array}{l}\text { Expoctor } \\
\text { Funds }\end{array}$ & FYSF & Varience \\
\hline $\begin{array}{l}\text { The Plateas } \\
1.2 \text { Waste Management } \\
\text { TP02,WM03-05 }\end{array}$ & & & & 103,378 & 100,378 & 3.000 & & & \\
\hline Line Item & & & & & & & & & \\
\hline Total Waste Mgt. Operating & & & & 103,378 & $\$ 100,378$ & $\$ 3,000$ & & & \\
\hline Total Waste Mgt. Line Item & & & & & & & & & \\
\hline
\end{tabular}

- Control Point

\section{ISSUES}

\section{Technical Issues}

Nothing to report at this time.

\section{DOE/Regulator/External Issues}

The Waste Management Programmatic Environmental Impact Statement (PEIS) was issued on February 25, 2000. These Records of Decision (ROD) for LLW and MLLW will affect Hanford's disposal role for the Complex and the ROD outcomes may have a significant impact on disposal volumes and rates at Hanford. DOE-HQ and WDOE negotiations continue; impacts depend upon results of these negotiations.

Hanford's TRU Project continues working with the Carlsbad Area Office (CAO), the Environmental Protection Agency (EPA) and the New Mexico Environment Department (NMED) to determine the appropriate path forward for recovery of the NDE/VE data generated prior to the WIPP Permit. CAO commitments to provide compliance matrices necessary to initiate the Hanford data evaluations were not met. The lack of consistency from $\mathrm{CAO}$ and failure to provide needed information has delayed initiation of the data recovery. When CAO concurred with the proposed Hanford path forward for data recovery, NDE data recovery efforts were initiated immediately. The method requires review of the original videotape and data by a qualified operator, completion of new batch data reports in accordance with current procedures, and validation of the batch data reports in accordance with current CAO Weekly Report for Week Ending July 14, 2000 procedures. Schedules for bringing all the "old" data forward are being developed based on the accepted method. 
Substantial areas of disagreement still exist between DOE-RL and Ecology on the required scope and content of the Annual LDR Submittal as delineated in the Final Determination issued by the Director of Ecology on March 29, 2000. DOE-RL is appealing certain aspects of the Ecology requirements, with formalized hearings scheduled for early in calendar year 2001.

Ecology continues to delay issuance of Modification $E$ of the Hanford Facility RCRA Permit. Ecology has stated that the permit will not be issued in July and probably not in August. Modification E will incorporate the CWC and the 616 NRDWSF Closure Plan into the RCRA Permit.

\section{Baseline Change Requests Currently in Process $(\$ 000)$}

\begin{tabular}{|c|c|c|c|c|c|c|c|c|c|}
\hline $\begin{array}{c}\text { PROJECT } \\
\text { CHANGE } \\
\text { NUMBER }\end{array}$ & $\begin{array}{c}\text { DATE } \\
\text { ORIGIN. }\end{array}$ & BCR TITLE & $\begin{array}{c}\text { FY00 COST } \\
\text { IMPACT } \\
\text { S000 }\end{array}$ & SCH & TECH & $\begin{array}{c}\text { DATE TO } \\
\text { CCB }\end{array}$ & $\begin{array}{c}\text { CCB } \\
\text { APR'VD }\end{array}$ & $\begin{array}{c}\text { RL } \\
\text { APR'VD }\end{array}$ & $\begin{array}{c}\text { CURRENT } \\
\text { STATUS }\end{array}$ \\
\hline WM-2000-006 & $3 / 21 / 00$ & $\begin{array}{c}\text { TRU Project } \\
\text { Rebaselining }\end{array}$ & $S-$ & & & $06 / 08 / 00$ & $06 / 08 / 00$ & & At DOE-RL \\
\hline & & & & & & & \\
\hline
\end{tabular}

\section{MiLestone ACHIEVEMENT}

\begin{tabular}{|c|c|c|c|c|c|c|c|c|}
\hline \multirow[b]{2}{*}{ MILESTONE TYPE } & \multicolumn{4}{|c|}{ FISCAL YEAR-TO-DATE } & \multicolumn{3}{|c|}{ REMAINING SCHEDULED } & \multirow[b]{2}{*}{$\begin{array}{l}\text { TOTAL } \\
\text { FY } 2000\end{array}$} \\
\hline & $\begin{array}{c}\text { Completed } \\
\text { Earty }\end{array}$ & $\begin{array}{c}\text { Completed } \\
\text { On Schedule }\end{array}$ & $\begin{array}{c}\text { Completed } \\
\text { Late }\end{array}$ & Overdue & $\begin{array}{l}\text { Forecast } \\
\text { Early }\end{array}$ & $\begin{array}{c}\text { Forecast On } \\
\text { Schedule }\end{array}$ & Forecast Late & \\
\hline Enforceable Agreement & 2 & 0 & 0 & 0 & 0 & 이 & 0 & 2 \\
\hline DOE-HQ & 0 & 요 & of & 0 & 0 & 0 & 0 & 0 \\
\hline $\begin{array}{r}\mathbf{R L} \\
\end{array}$ & 0 & 요 & 요 & 0 & 0 & 8 & $\overrightarrow{0}$ & 8 \\
\hline Total Project & 2 & 0 & 0 & 0 & 0 & 8 & 0 & 10 \\
\hline
\end{tabular}




\section{Green}

\section{Tri-Party Agreement / EA Milestones}

\begin{tabular}{|l|l|l|}
\hline \multicolumn{1}{|c|}{ Number } & \multicolumn{1}{|c|}{ Milestone Title } & \multicolumn{1}{c|}{ Status } \\
\hline $\begin{array}{l}\text { M-91-03 } \\
\text { (WMH-00- } \\
\text { 001) }\end{array}$ & $\begin{array}{l}\text { Issue TRU/TRUM } \\
\text { Waste PMP }\end{array}$ & due 06/30/00 - Completed 6/29/2000 (stretch) \\
\hline $\begin{array}{l}\text { M-91-04 } \\
\text { (A2J-00-001) }\end{array}$ & $\begin{array}{l}\text { Complete Construction } \\
\text { of CH TRU/TRUM } \\
\text { Retrieval Facility }\end{array}$ & $\begin{array}{l}\text { due 09/29/00 - DOE-RL issued a letter to Ecology on February 29, } \\
\text { initiated and is planned to continue, even without construction of } \\
\text { Project W-113 facilities. }\end{array}$ \\
\hline & & \\
\hline
\end{tabular}

\section{DNFSB Commitments}

\begin{tabular}{|l|l|l|}
\hline & Nothing to report. & \\
\hline & & \\
\hline
\end{tabular}

\section{MILESTONE EXCEPTION REPORT}

Number/WBS Level Milestone Title $\quad \begin{array}{ll}\text { Baseline } & \begin{array}{l}\text { Forecast } \\ \text { Date }\end{array}\end{array}$

\section{OVerdue - 0}

\section{FORECAST LATE - 0}

\section{FY 1999 OVERDUE - 1}

$\begin{array}{llll}\text { TRP-98-709 RL Complete Hot Cell Deactivation } & 03 / 31 / 99 & 09 / 30 / 00\end{array}$

\subsubsection{WESF Facility (A-E)}

Cause: This milestone is not complete due to not being supported at the current funding level.

Impact: No overall impact is expected.

Corrective Action: Return-on-Investment (ROI) funding has been identified for this work scope and a new forecasted completion date of September 30, 2000 established. 


\section{Performance Objectives MLLW TREATMENT}

\section{Green}

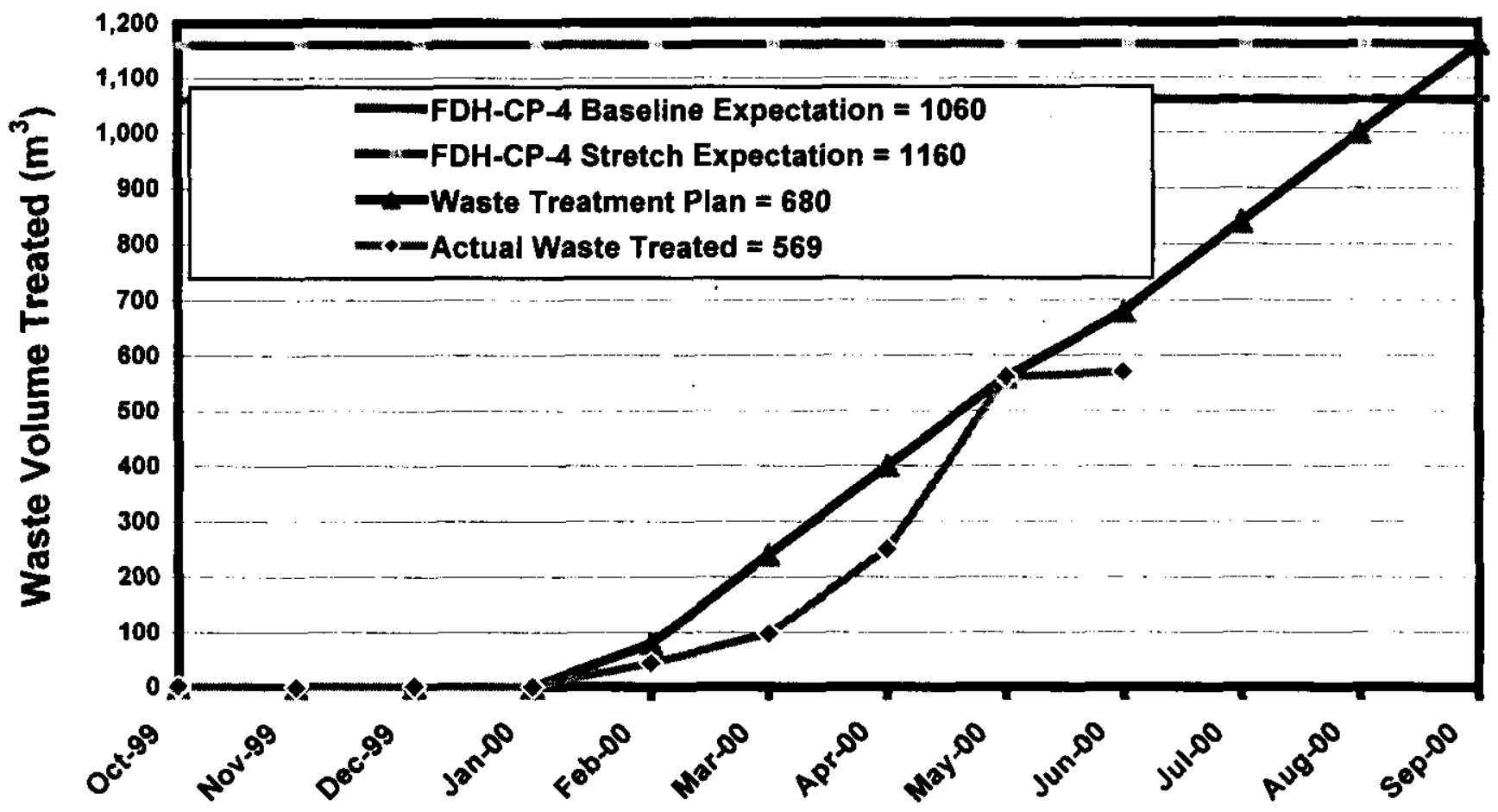

Action Plans: Minimum requirement of $560 \mathrm{~m} 3$ treated completed in June 2000 . Behind schedule to treat the remaining $500 \mathrm{~m} 3$ due to paperwork issues; recovery expected in August 2000.

MLLW DISPOSAL

Green

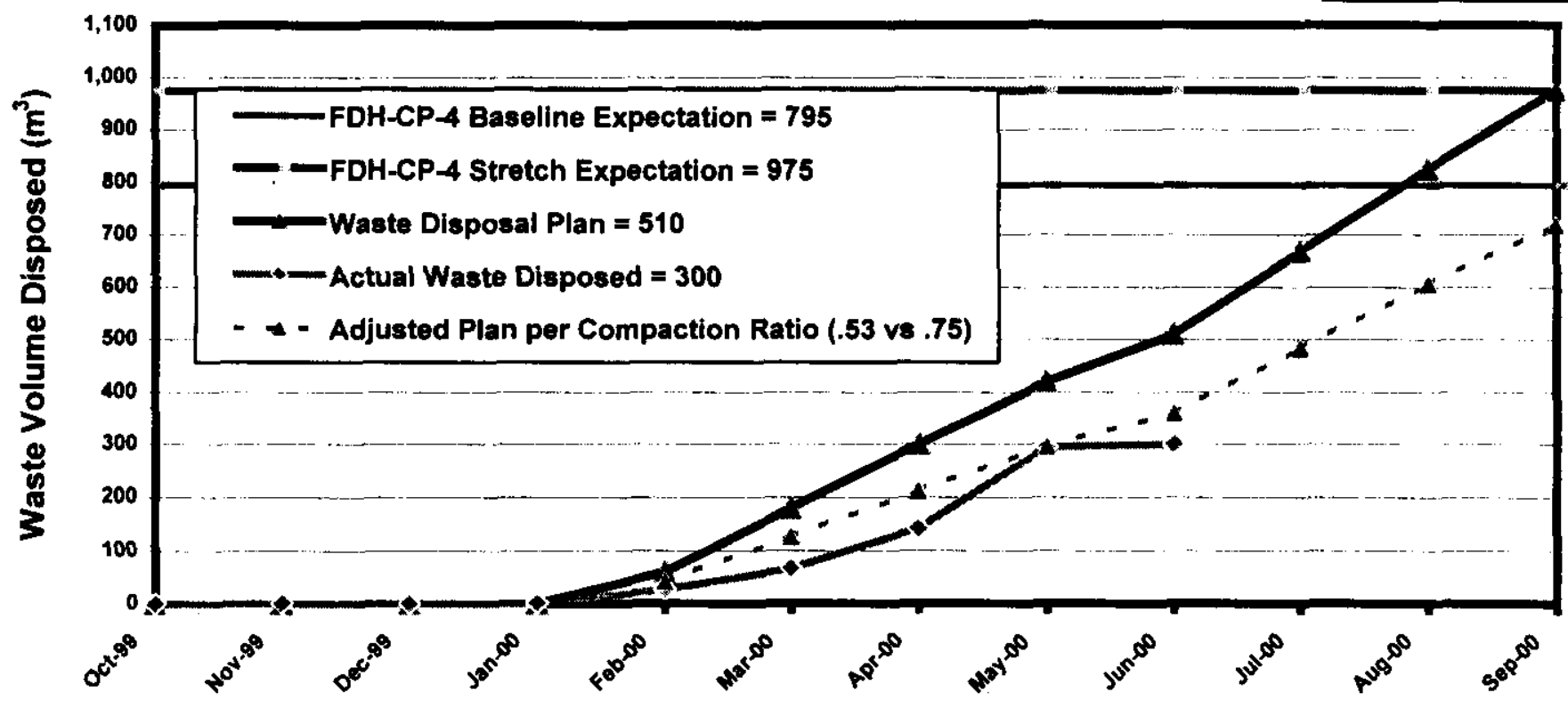

Action Plans: Behind due to treatment slippage. Recovery expected in August 2000. 
PHMC Environmental Management Performance Repord +148 ust 2000

Section B: 1 - Waste Management

TRU RETRIEVAL

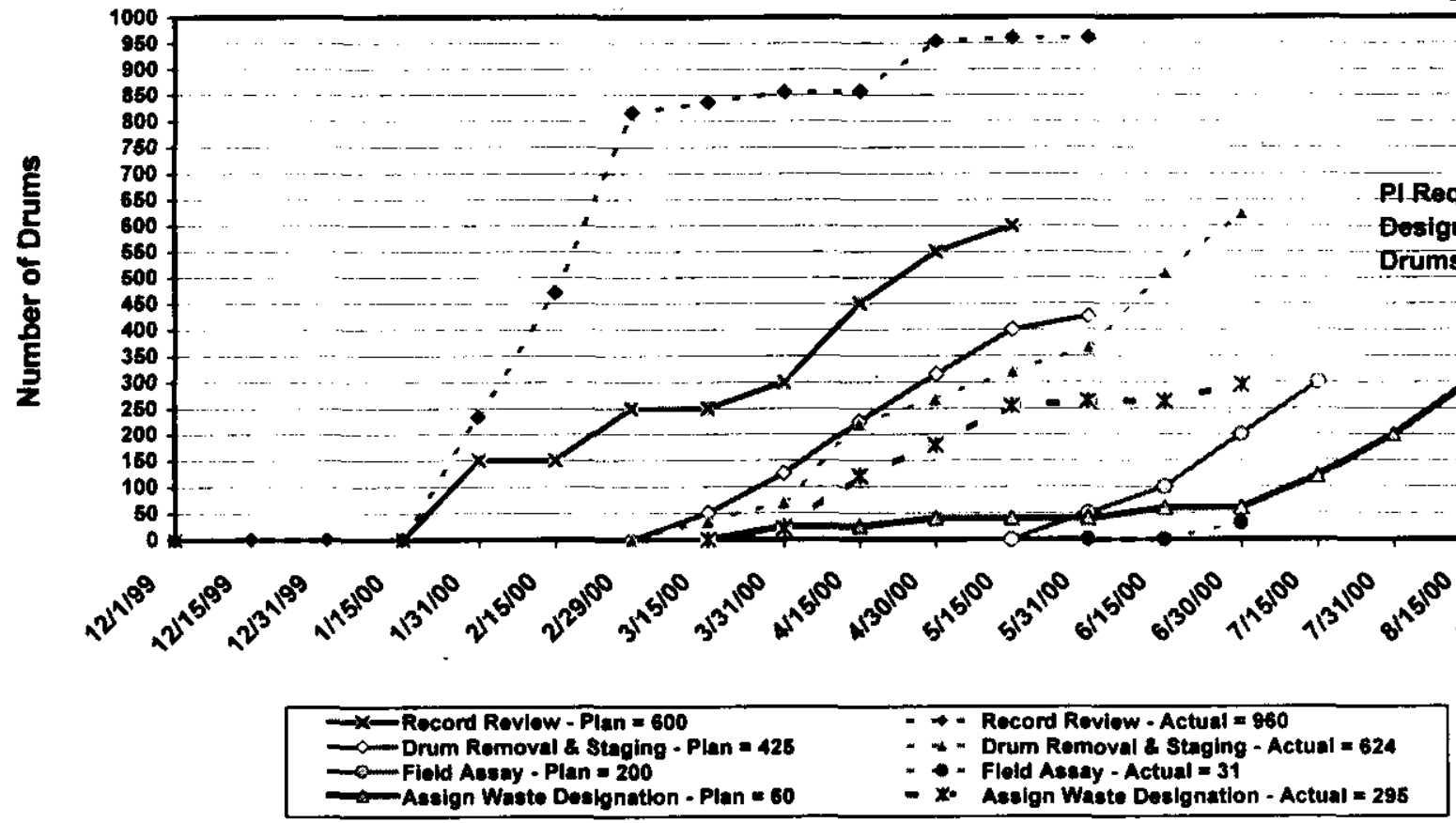

Action Plans: On track to meet the new stretch goal of 425 drums

\section{tru Container Processing}

\section{Green}

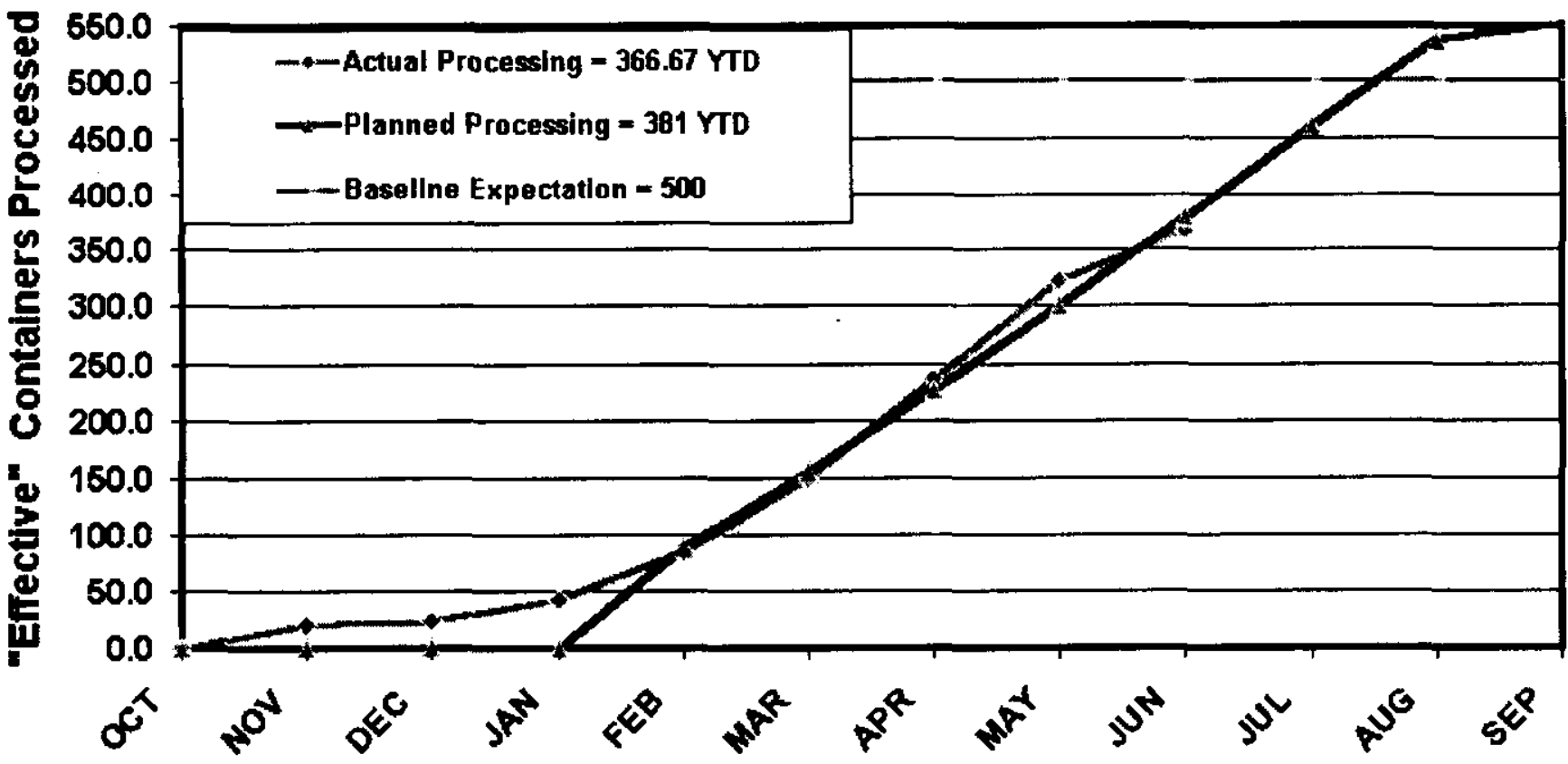

Action Plans: On track. 


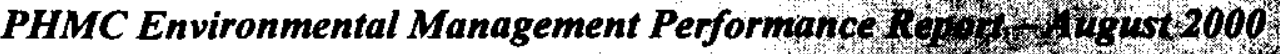

Section B: 1 - Waste Management

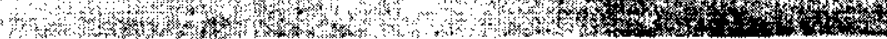

\section{TRU Certification for SHIPPING}

\section{Green}

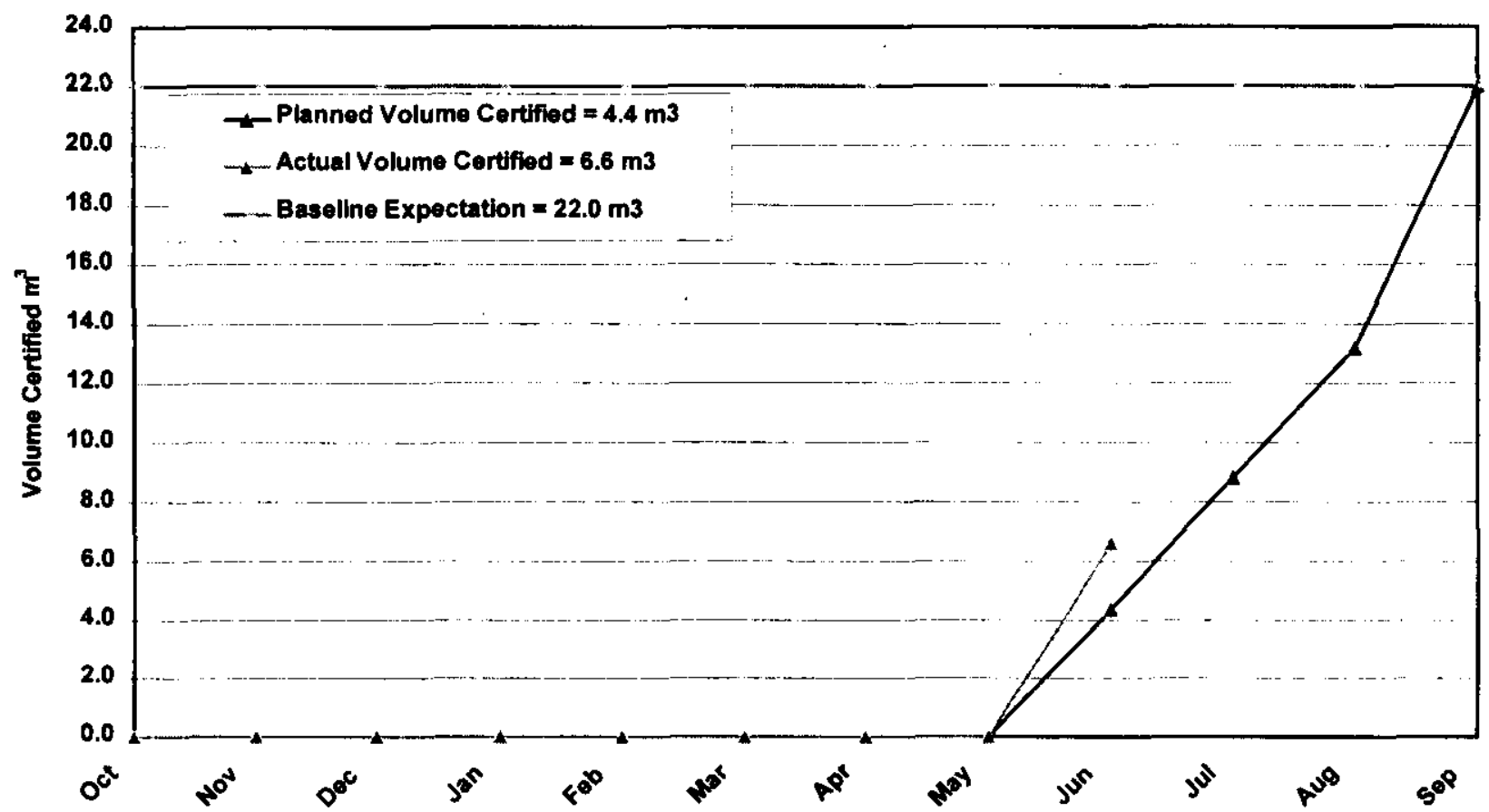

Action Plans: PI renegotiation in process.

\section{LIQUid WASTE Processing}
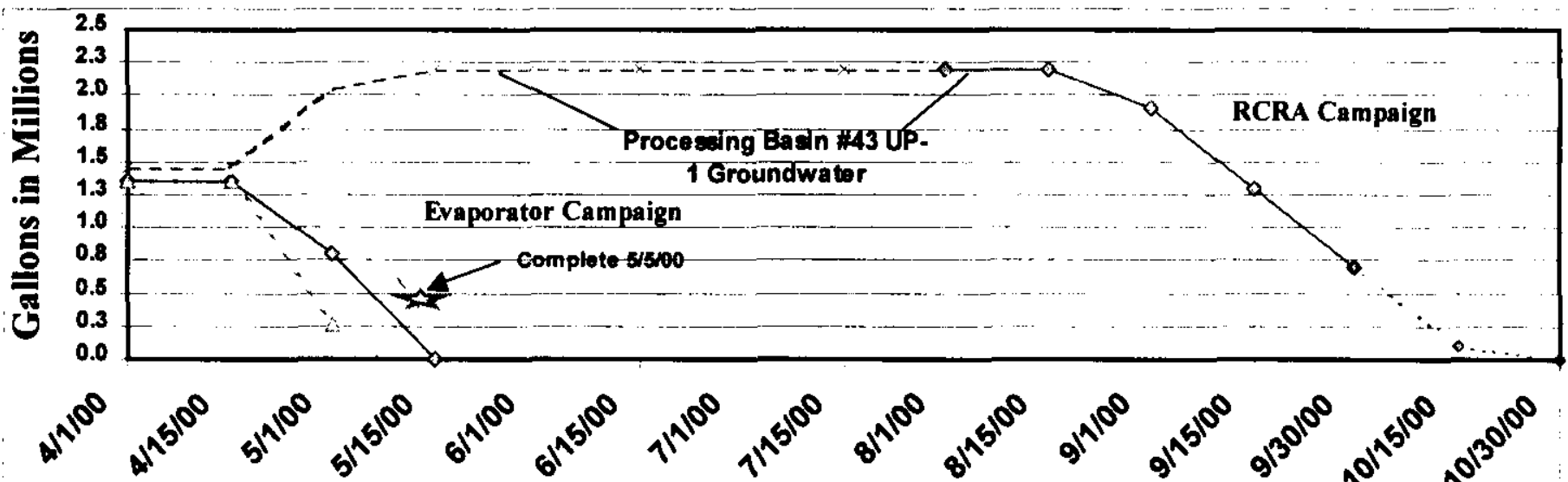

$\sim 242$ Avaporator Campaign Plan

_- Basin 442 RCRA Campaign Plan

. . ... Completion of Campaign (Not PI requirement)
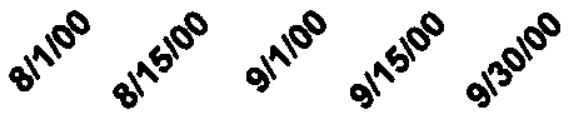
- 242-A Eva porator Campajgn Actual
Basin \#42 RCRA Campaign Actual - - Basin \#42 RCRA Estimated Volume

Action Plans: On track. The RCRA campaign scheduled to begin in mid-August 2000 . 


\section{T Plant Deck Clearing (RC-4-1-1)}

\section{Green}

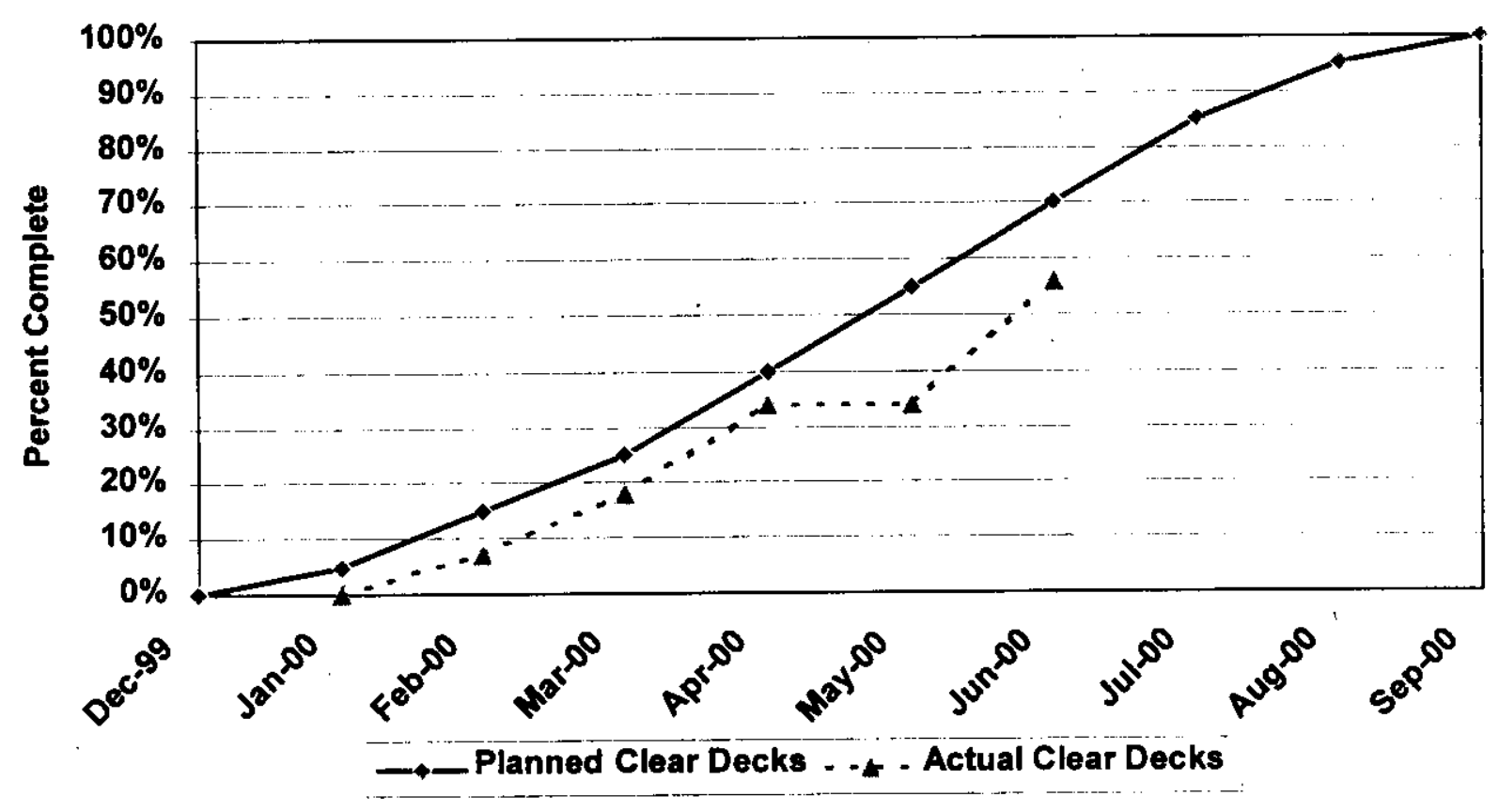

Action Plans: Ramping up for completion in September 2000.

T PLANT PEP AND CDD

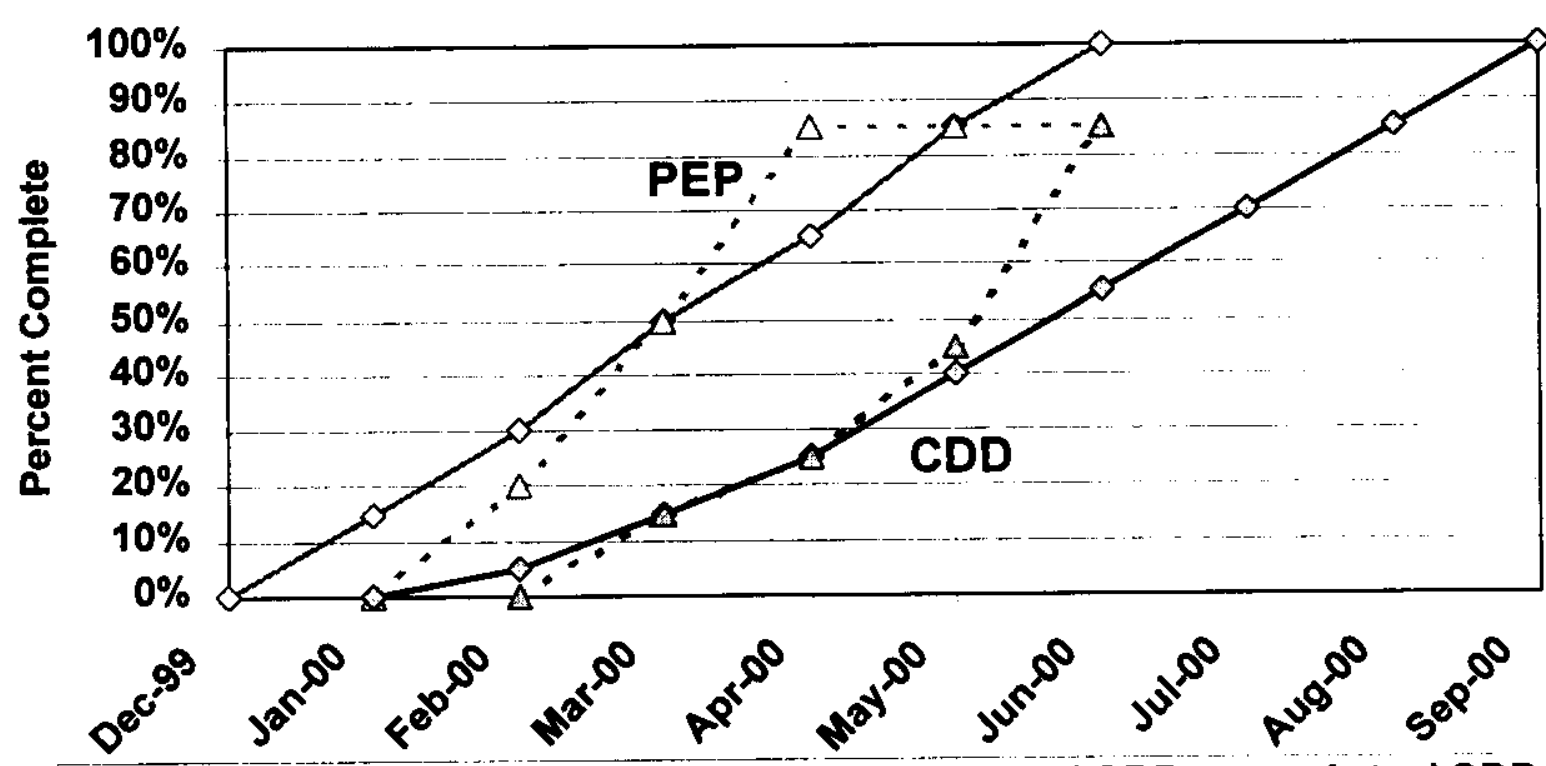
$\sim$ Planned PEP . $-\Delta$ - Actual PEP $\sim$ Planned CDD - $-\Delta$ - Actual CDD

Action Plans: On track for completion in fiscal year 2000. The Project Execution Plan (PEP) and the Conceptual Design Document (CDD) are both 85 percent complete. PEP completion is tied to required CDD inputs; both will be completed by September 30, 2000. 


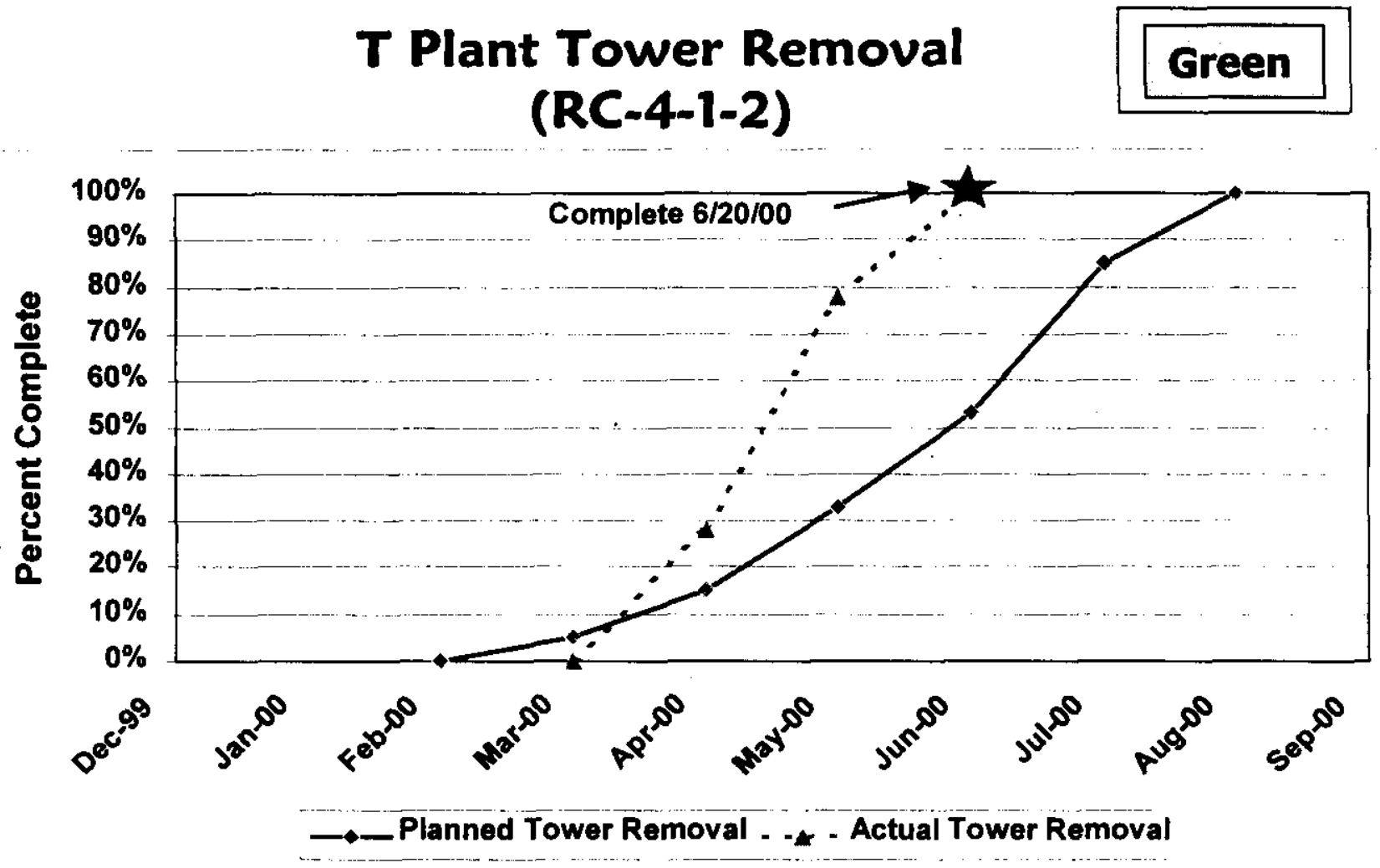

Action Plans: Complete. Two towers removed and disposed of in the low level burial grounds (LLBG).

\section{KEY INTEGRATION ACTIVITIES}

- $\quad$ Preparing T Plant to receive Spent Nuclear Fuel K Basin sludge.

- Issuance of Records of Decision for LLW and MLLW is expected to affect Hanford's role in disposing of waste from other sites. Working with DOE-RL, DOE-HQ and other Sites to develop and define Hanford's role as one of the identified LLW/MLLW disposal sites for the Complex.

- $\quad$ Support continued UP-1 Groundwater treatment.

- $\quad$ Support River Corridor Project in cleanup and removal of waste from 324 and 327 buildings.

- $\quad$ Continue working with PNNL, EM 50 and Mixed Waste Focus Area (MWFA) to obtain funding in support of mixed waste processing (M-91 Facility Project).

- Continue to work with DOE- RL, -Oakland, and -Ohio to support resolution of TRU small quantity site disposition issues. 


\section{High LeVel. WASTE (HLW): Storage AND TREATMENT}

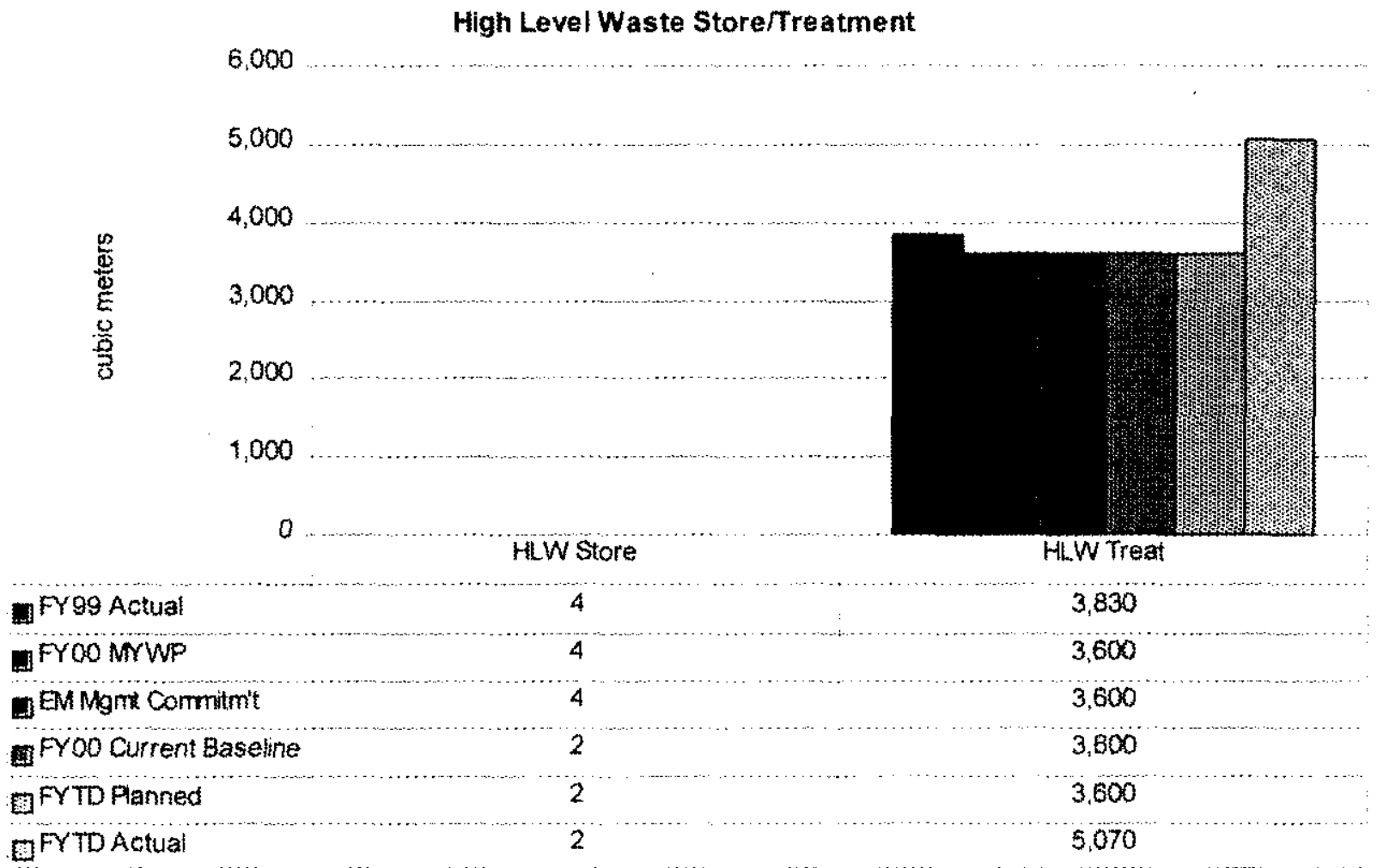

Storage: The HLW inventory of the Cesium (Cs) and Strontium 90 ( $\mathrm{Sr}$ ) stored in the Waste Encapsulation and Storage Facility (WESF) pool cells has been adjusted to provide a consistent reporting basis. The previously reported four cubic meters was based on the capsule dimensions. However, the reported HLW inventory should have included the volume that is HLW (i.e., the Cs and Sr salt) which is two cubic meters. The HLW Cs and Sr salt volume will be the basis for future reporting.

Treatment: The FY00 evaporator campaign for treatment of high-level tank waste was completed during the third quarter, treating more than 34 percent more than planned. Additional volume treated through the evaporator was necessary to support RPP in achieving a Performance Incentive for waste volume reduction in the Tank Farms underground storage tanks. 


\section{TransUranic (TRU) Waste: Storage, Treatment and Disposal}

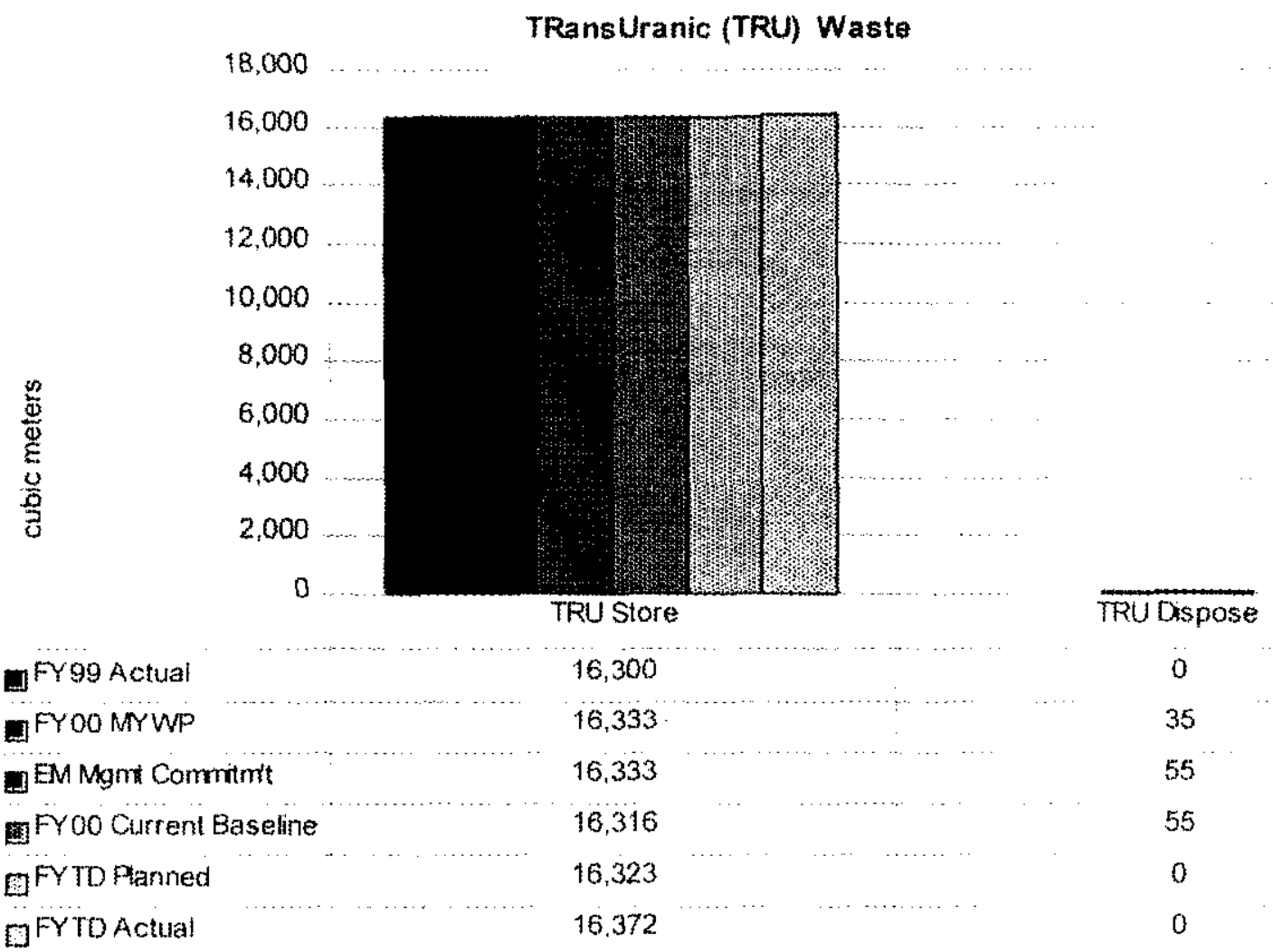

Storage: Storage continues to be provided for existing and newly generated TRU waste. The current volume of TRU in storage is within 10 percent of the planned amount.

Treatment: Based on DOE/RL interpretation, TRU processing at WRAP does not meet the revised TRU treatment definition. Therefore, TRU treatment volumes previously identified in the FYOO MYWP have been set to zero.

Disposal: None scheduled this period. 


\section{Mixed Low level Waste: Storage, Treatment, and Disposal}

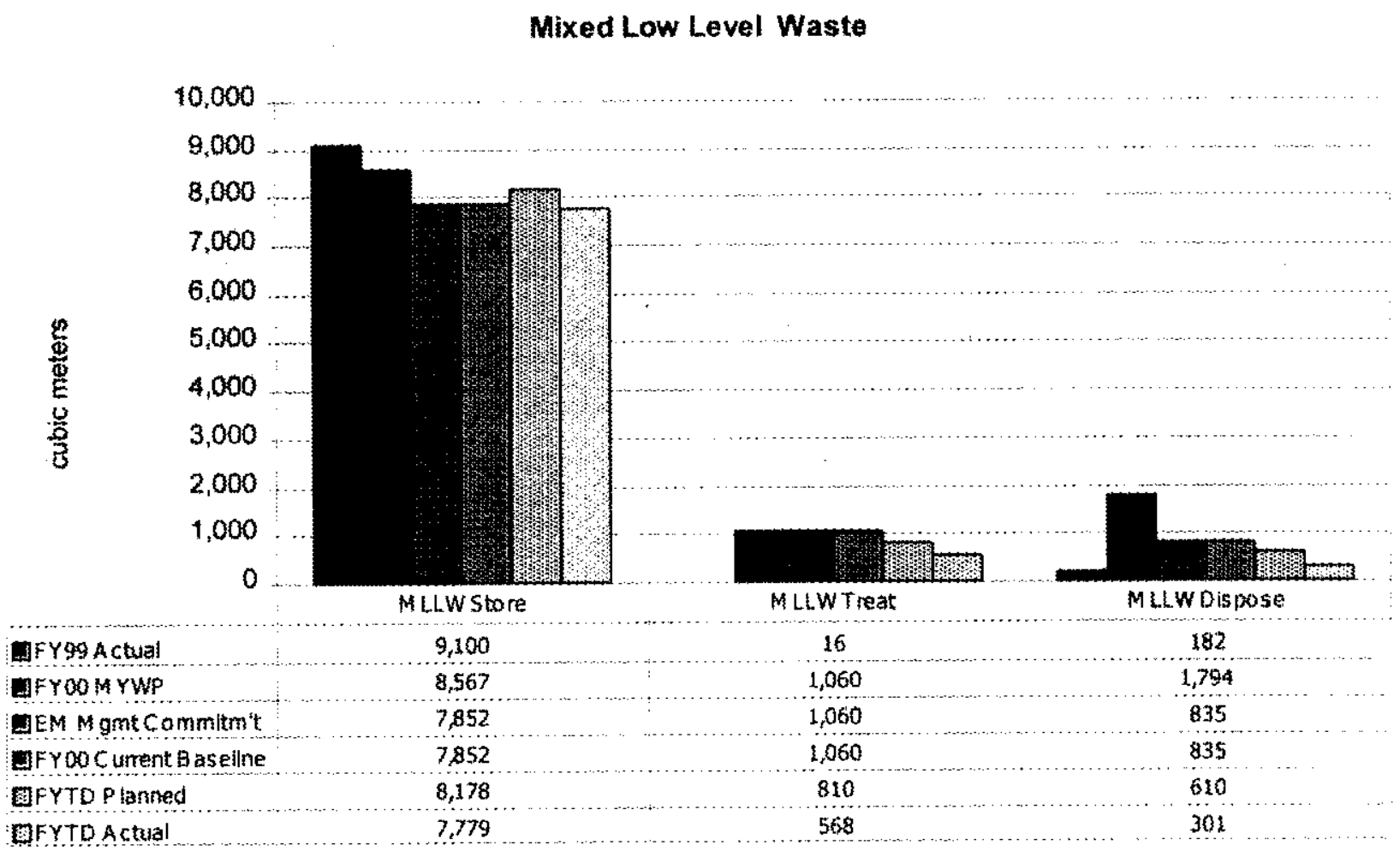

Storage: Storage continues to be provided for existing and newly generated MLLW waste. The current volume of MLLW in storage is within 10 percent of the planned amount.

Treatment: Treated volumes are currently running lower than projected as Allied Technology Group (ATG) received their treatment permit later than originally anticipated causing a domino effect to the treatment volumes. A second impact to the treatment volumes is, at the time of planning a reduction rate of $1: .75$ was assumed. Currently the actual reduction rate is $1: 5$. ATG has ramped up and plan to meet the year-end planned amount.

Disposal: Disposed volumes lag as treatment has a direct impact on the disposal volumes. Based on the current volume reduction rate discussed above, the disposed volume for the end of the year will be less than planned. 


\section{LOW LEVEL WASTE (LLW): STORAGE, TREATMENT, AND DISPOSAL}

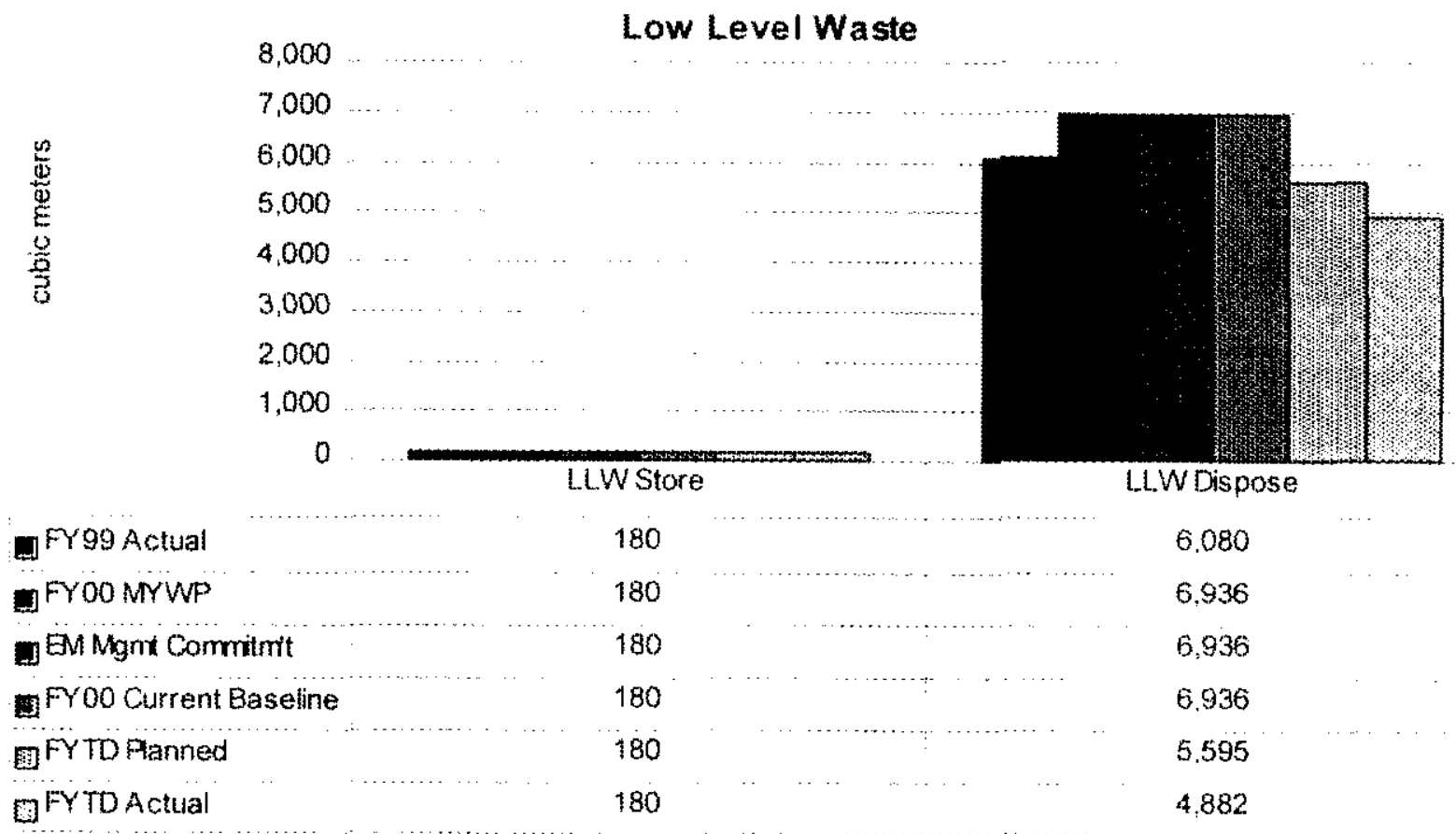

Storage: Storage remains unchanged for LLW not suitable for disposal. Contracting for commercial treatment of this waste is planned for FY2007.

Treatment: No treatment of LLW is planned until after FY2006 when a treatment alternative has been selected. All newly generated LLW receipts are prepared and packaged to the waste acceptance criteria for disposal of LLW in the burial grounds and no further treatment is required.

Disposal: Scheduled slipped for several LLW generators therefore actual volume of LLW disposed is below planned. One high volume generator is behind their projected volume due to excavation activities taking longer than anticipated. LLW disposal is expected to be with 10 percent of the planned year end volume as generators make up their schedule slippages. 


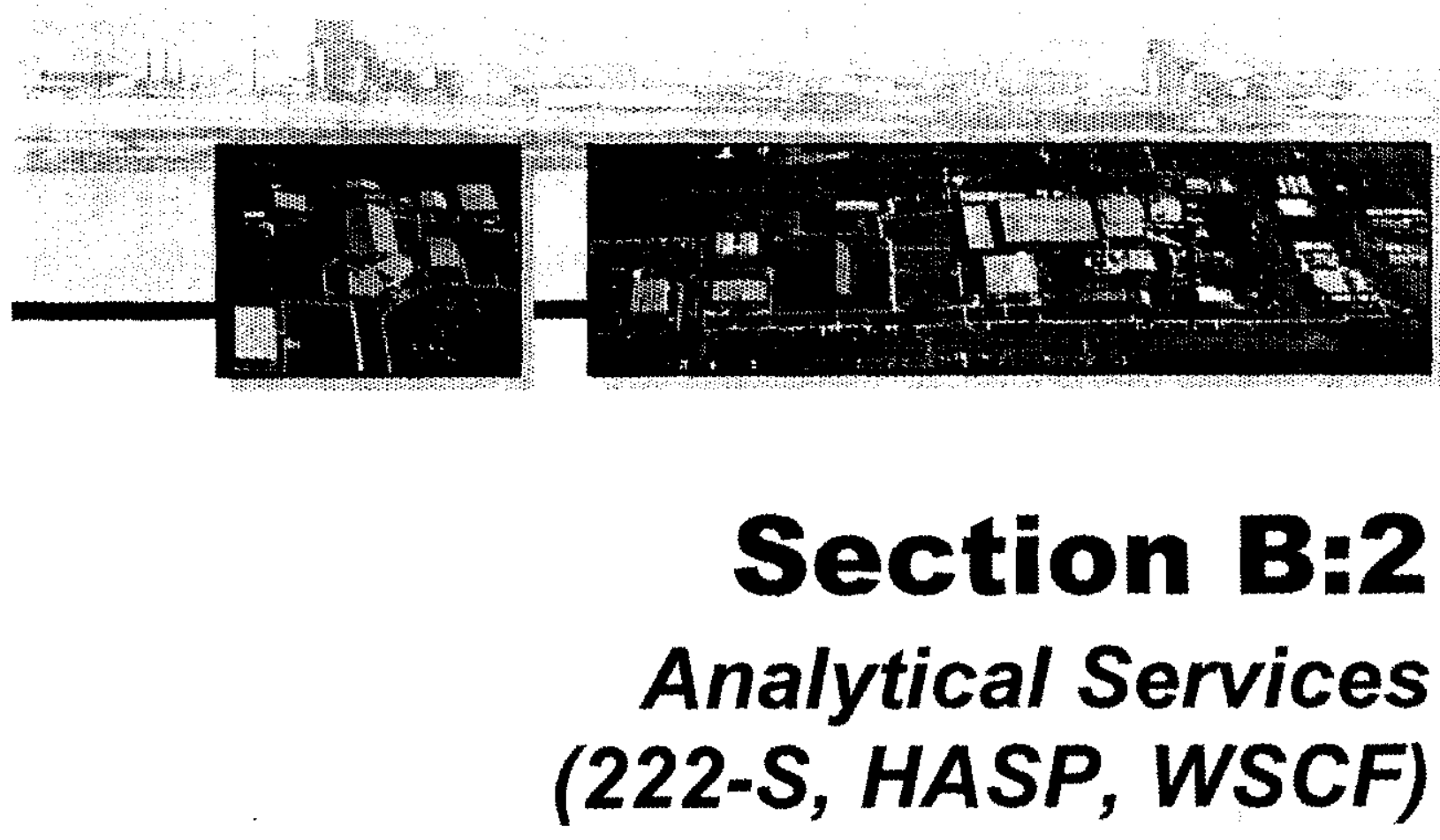

PROJECT MANAGERS S.H. Wisness, RL (509) 373-9337

D.L. Renberger, FH (509) 372-0877 


\section{SUMMARY}

Analytical Services [222-S, Hanford Analytical Services Program (HASP), Waste Sampling and Characterization Facility (WSCF)] consists of Analytical Services, PBS WM06, WBS 1.2.4.

NOTE: Unless otherwise noted, the Safety, Conduct of Operations, Milestone Achievement, and Cost/Schedule data contained herein is as of June 30,2000. Other information is updated as noted.

Fiscal-year-to-date-milestone performance (EA, DOE-HQ and RL) shows no milestones are due this reporting period.

\section{ACCOMPLISHMENTS}

- A total of 1.1 Analytical Equivalent Unit (AEUs) processed at the 222-S Laboratory in June 2000 (FYTD) versus the planned 1.2 AEUs in support of the RPP (TWRS) tank characterization program. Production FYTD through July 14, 2000 is 9.7 AEUs. On track to meet the $11 \mathrm{AEU}$ commitment. Agreement was reached with the River Protection Project on remaining support needed for FY 2000.

- $\quad$ Performed 1500 analyses in June at Waste Sampling and Characterization Facility (WSCF) for a wide variety of customers as planned. FYTD production through July 19, 2000 is 13,900 analyses.

- Analytical Services Training identified a method to simplify the tracking of the Chemical Technologist Training Program that significantly decreases the number of qualification cards. Job scope specific training can be tracked using an existing database instead of through Qualification Cards. This method greatly simplifies tracking requirements and increases the flexibility of the program.

\section{SAFETY}

In June, there were no Occupational Safety and Health Act (OSHA) recordable or lost/restricted days, and one first aid cases. OSHA recordable case rate is stable at a rate higher than the Project Hanford Management Contract (PHMC) goal of 0.9. For the past six months the Lost Away Case Rate have been below average; a seventh month will be a significant improvement. The project continues to focus on safety and personal and team accountability. A safety council sponsored, employee-lead task team is working to develop near-term and long-term improvements in the ergonomics of handling small casks (called T-handled carriers). Ergonomic self-assessments are occurring for all Analytical Services staff in June and July 2000.

Ergonomics have been a source of injuries that need to be prevented. 
12

10

8

6 - $1,600,000$ hours without
a Lost Away Work Day Case
(Oct 96 - Apr 99)

4

2

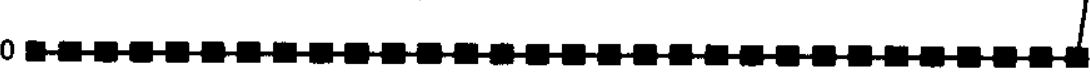

12: OSHA Recordable Case Rate Cases per 200,000 hours
Project Safe Hours $=351,591$

FY $1999=0.4$

FY 2000 to date $=0.9$
Green

7

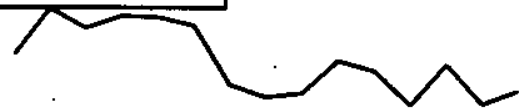

Average $\square 1.4$

(Apr 99 - Nov 99)

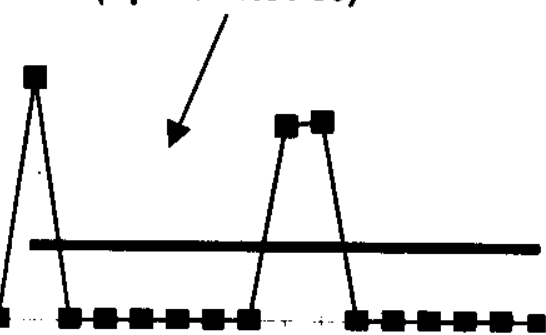

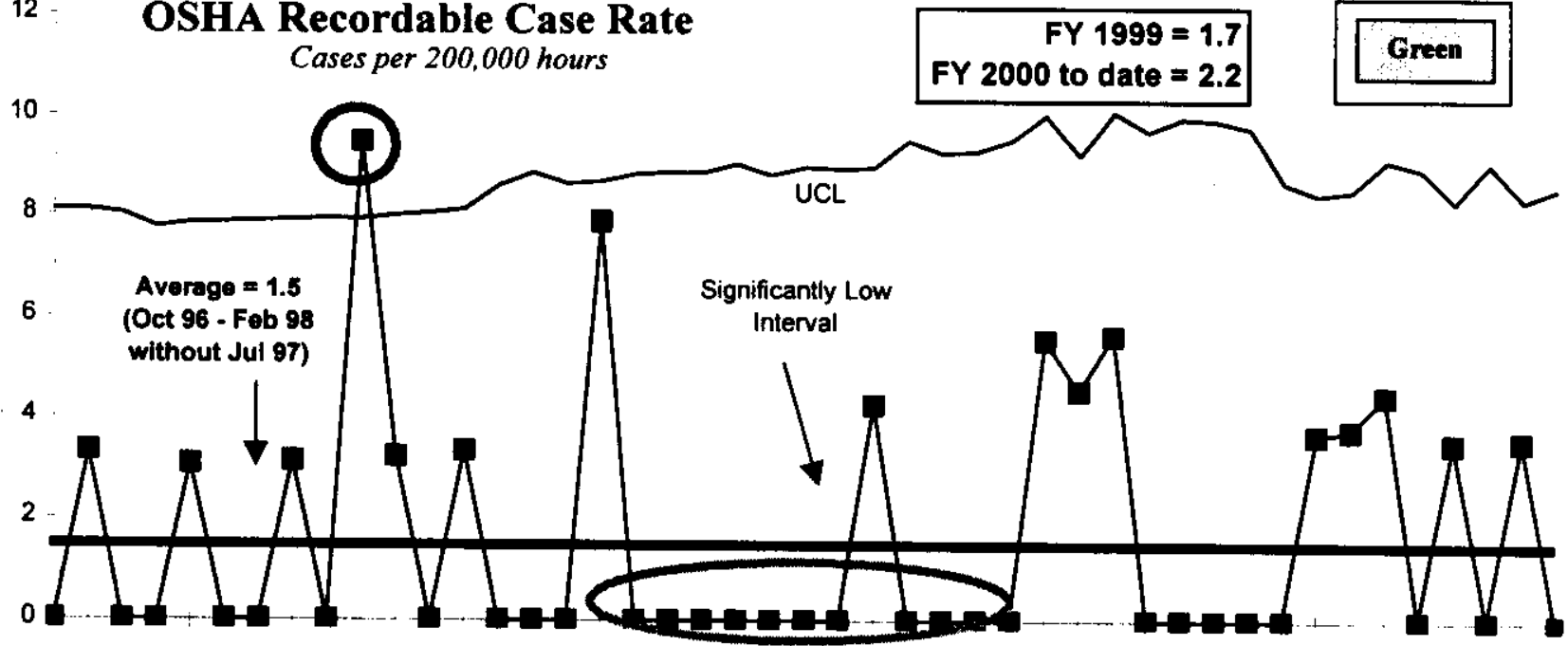

DOE Safety Cost Index

Cents per hour
Average $=4.4$
(Oct $96-$ Fob 98
wthout Jul 97 )

100

90

80

70

60

50

50

40

30

20

10

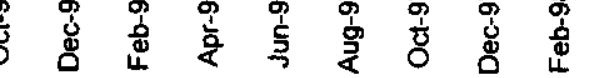

DOE/RL-99-83, Rev. 7
FY $1999=7.5$

2000 to date $=18.3$

UCL

交 Month of Injury / IIIness
Green
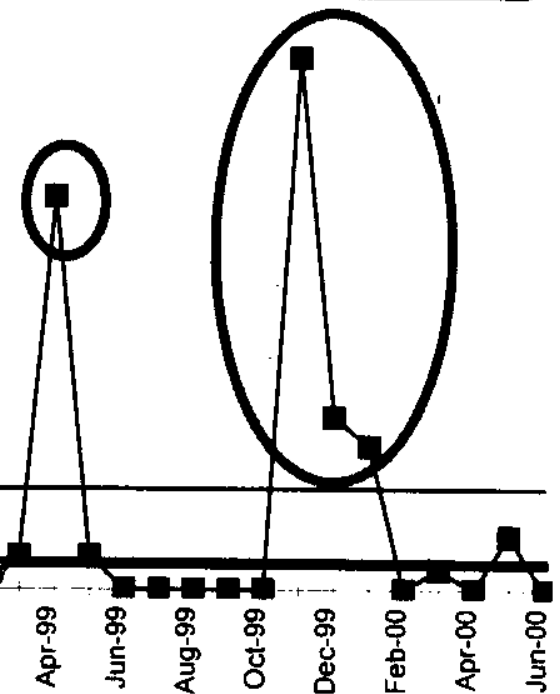

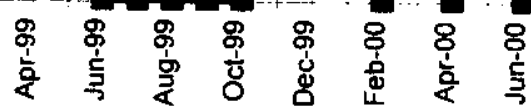




\section{CONDUCT OF OPERATIONS / ISMS STATUS CONDUCT OF OPERATIONS EVENTS PER 200,000 HOURS}

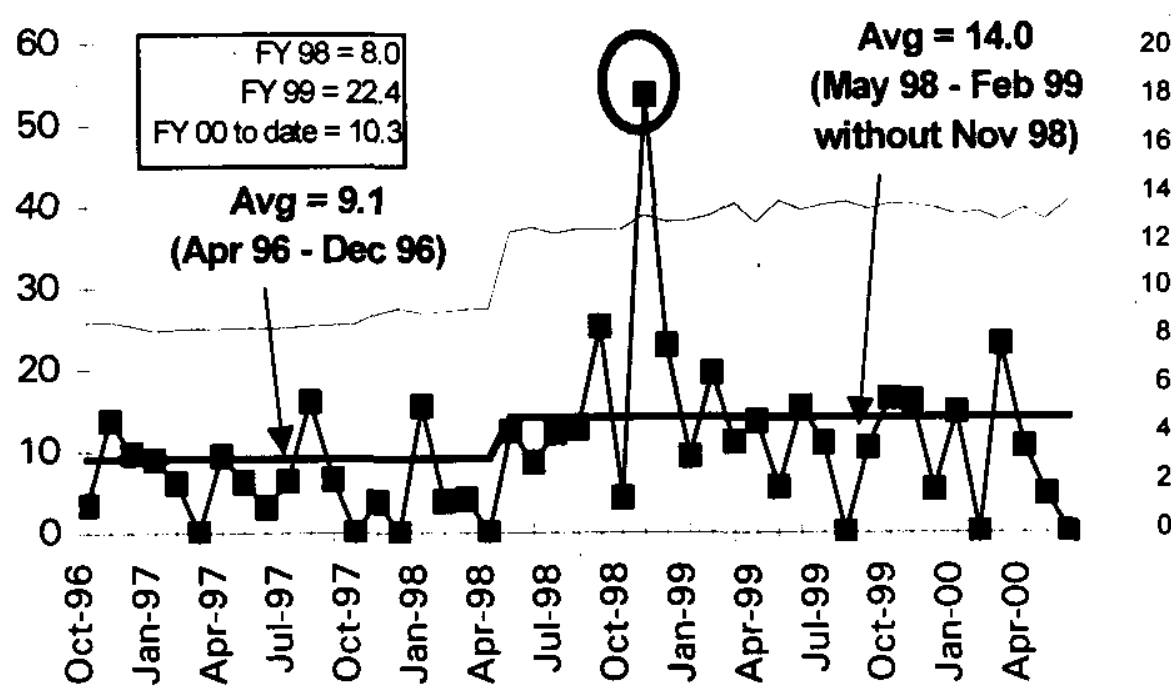

No. of Reports

Past 12 Months

ISMS STATUS

Analytical Services ISMS status is included in the Waste Management

Project Section of this report. Supported successful completion of the Phase II verification.

\section{BREAKTHROUGHS}

Nothing to report.

\section{OPPORTUNITIES FOR IMPROVEMENT}

Analytical Services Facility and Equipment Upgrades Team: RL is assessing the framework under which it can maximize its cleanup while working to incorporate a "realistic" funding profile over the next ten to fifteen years. Consistent with the RL outcomes, the priority is on achieving its River Corridor Outcome by 2010 or shortly thereafter. That necessitates a probable re-sequencing of the current baseline activities in the 200 Areas. An Analytical Services Facility and Equipment Upgrades Team is working to identify opportunities for improvement.

\section{UPCOMING ACTIVITIES}

WIPP Waste Shipments - Continue to support the production goal of headspace analysis in support of waste shipment to WIPP. 
ORP Readiness to Proceed - It has been determined that Analytical Services is prepared to support the readiness to proceed decision for the Office of River Protection (ORP) Waste Treatment Plant. Key follow-up actions are:

- Formal specification of requirements from ORP to RL and then to FH

- Stable funding of needed equipment and facility repair in Multi-Year Work Plans (RL and ORP) - (see Opportunities for Improvement section)

- Funding replacement of obsolete laboratory support systems (Information Management)

- Funding of staff to maintain core competency.

\section{Cost Performance (\$M):}

\begin{tabular}{|l|c|c|c|}
\hline & BCWP & ACWP & VARIANCE \\
\hline Analytical Services & $\$ 20.5$ & $\$ 20.2$ & $\$ 0.3$ \\
\hline
\end{tabular}

The $\$ 0.3$ million ( 1 percent) favorable cost variance is within established thresholds.

\section{SChedule Performance (\$M):}

\begin{tabular}{|l|c|c|c|}
\hline & BCWP & BCWS & VARIANCE \\
\hline Analytical Services & $\$ 20.5$ & $\$ 20.8$ & $-\$ 0.3$ \\
\hline
\end{tabular}

The $\$ 0.3$ million ( 2 percent) unfavorable schedule variance is within the established threshold.

\section{FY 2000 Cost/Schedule Performance - All Fund Types Cumulative to Date Status - $(\$ 000)$}

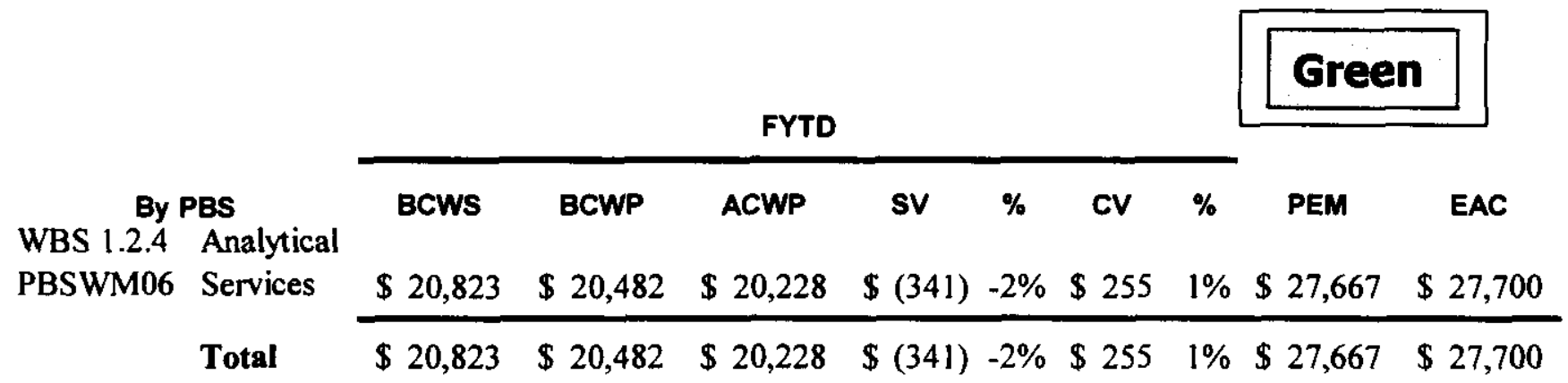

*Note: RL-Directed costs (steam and laundry) are included in the PEM BCWS/ACWP. 
PHMC Environmental Management Performance Report 1407,2000

Section B: 2 - Analytical Services (222-S, HASP, WSCH)

\section{Cost/Schedule Performance Indices (MONTHLY AND FYTD)}

Green

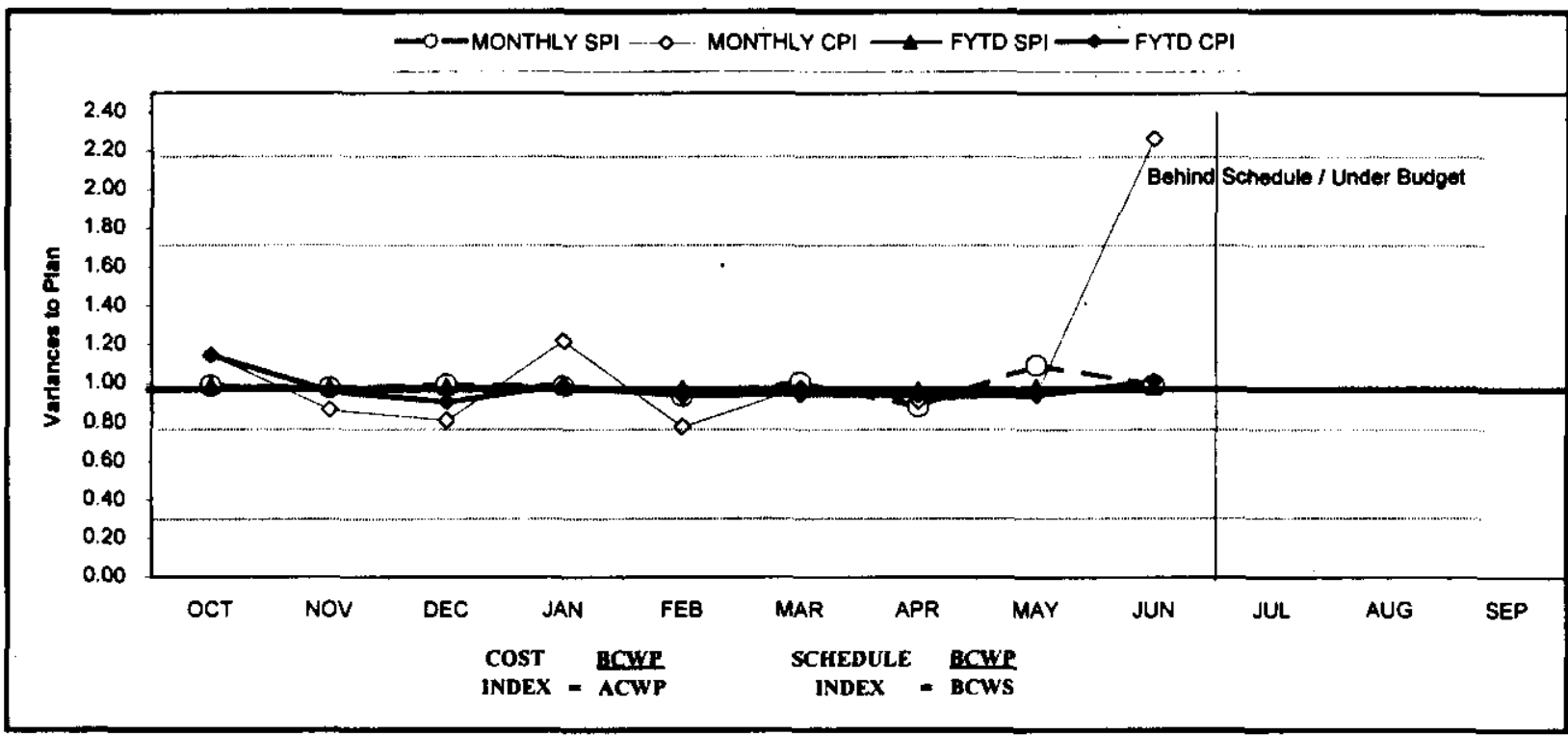

\begin{tabular}{|c|c|c|c|c|c|c|c|c|c|c|c|c|}
\hline FY 2000 & OCT & NOV & DEC & JAN & FEB & MAR & APR & MAY & JUN & JUL & AUG & SEP \\
\hline MONTHLY SPI & 0.99 & 0.98 & 0.99 & 0.98 & 0.94 & 1.00 & 0.88 & 1.09 & 0.99 & & & \\
\hline MONTHLY CPI & 1.14 & 0.87 & 0.81 & 1.22 & 0.78 & 0.98 & 0.91 & 0.94 & 2.26 & & & \\
\hline FYTD SPI & 0.99 & 0.98 & 0.99 & 0.98 & 0.97 & 0.98 & 0.97 & 0.98 & 0.98 & & & \\
\hline FYTD CPI & 1.14 & 0.96 & 0.91 & 0.99 & 0.94 & 0.95 & 0.94 & 0.94 & 1.01 & & & \\
\hline MONTHLY BCWS & 51,588 & $\$ 2,340$ & $\$ 1,973$ & $\$ 2,896$ & $\$ 2,283$ & $\$ 2,613$ & $\$ 2,279$ & $\$ 2,358$ & $\$ 2,493$ & 51,893 & $\$ 2,507$ & $\$ 2,444$ \\
\hline MONTHLY BCWP & S1,566 & $\$ 2,288$ & $\$ 1,960$ & 52,848 & $\$ 2.135$ & $\$ 2,624$ & $\$ 2,010$ & 52,578 & $\$ 2,473$ & & & \\
\hline MONTHLY ACWP & $\$ 1,369$ & $\$ 2,640$ & $\$ 2,414$ & $\$ 2,342$ & $\$ 2.741$ & 52.686 & $\$ 2,208$ & 52,733 & $\$ 1,093$ & & & \\
\hline FYTD BCWS & $\$ 1,588$ & $\$ 3,928$ & 55,901 & 58,797 & $\$ 11,080$ & 513,693 & $\$ 15,973$ & $\$ 18,330$ & 520,823 & $\$ 22,716$ & $\$ 25,224$ & $\$ 27,667$ \\
\hline FYTD BCWP & $\$ 1,566$ & $\$ 3,854$ & 55,814 & 58,662 & $\$ 10,797$ & $5 \longdiv { 3 , 4 2 1 }$ & 515,431 & $\$ 18,009$ & $\$ 20,482$ & & & \\
\hline FYTD ACWP & $\$ 1,369$ & $\$ 4,009$ & 56,423 & $\$ 8,765$ & $\$ 11,506$ & $\$ \longdiv { 1 4 , 1 9 3 }$ & $S 16,401$ & $\$ 19,134$ & $\$ 20,228$ & & & \\
\hline
\end{tabular}

\section{COST VARIANCE ANALYSIS: $(\$ 0.3 \mathrm{M})$}

\section{WBS/PBS}

\subsection{4/WM06}

\section{Title}

\section{Analytical Services}

.

Impact: Current yearend spending projections indicate a $\$ 0.3 \mathrm{M}$ overrun.

Corrective Action: Corrective actions have been identified and implemented to control spending. 


\section{SCHedule VARIANCE ANalysis: (-\$0.3M)}

\section{WBS/PBS}

1.2.4/WM06
Title

Analytical Services

Description /Cause: The unfavorable schedule variance of $\$ 0.3 \mathrm{M}$ (2 percent) is within established threshold.

Impact: None.

Corrective Action: None required.

\section{FUNDS MANAGEMENT FUNDS US SPENDING FORECAST $(\$ 000)$ FY TO DATE THROUGH JUNE 2000 (FLUOR HANFORD, INC. ONLY)}

\begin{tabular}{|c|c|c|c|c|c|c|c|c|c|}
\hline & \multicolumn{3}{|c|}{ Project Complajon } & \multicolumn{3}{|c|}{ Post2006 } & \multicolumn{3}{|c|}{ Lanolems } \\
\hline & $\begin{array}{l}\text { Expinivis } \\
\text { Funds }\end{array}$ & FYSF & Variance & $\begin{array}{l}\text { Expincinde } \\
\text { Funde }\end{array}$ & FYSF & Verience & $\begin{array}{l}\text { Eqpiciad } \\
\text { Funds }\end{array}$ & FYSF & Variance \\
\hline 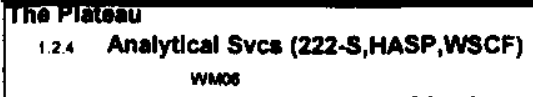 & & & & 28,461 & 26,853 & $\begin{array}{r}(392) \\
0\end{array}$ & & & \\
\hline LIne Item & & & & & & & & & \\
\hline 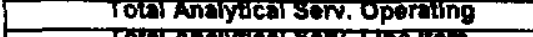 & & & & 26,461 & 26,803 & (352) & & & \\
\hline
\end{tabular}

- Control Point

\section{ISSUES}

\section{Technical Issues}

Nothing to report.

\section{DOE/Regulator/External Issues}

PCB Management - ORP is establishing a new PCB management approach. Impacts to 222-S and WSCF could be significant, depending on the final approach taken by ORP. DOE-RL plans to seek funding from ORP to assess impacts and implementation costs of ORP changes in regulation approach. Provided input and supported a FH team to respond to the ORP negotiations being held with EPA on the PCB status of the tank farms.

222-S RCRA Part B Application - DOE-RL received letter notification from Ecology granting a delay in submittal of the 222-S Laboratory Part B RCRA Application until August 31, 2000. This delay is shorter than requested. Analytical Services is on schedule for delivery on the accelerated date. Analytical Services will deliver the Part B to DOE-RL by August 1, 2000 for certification review. 


\section{Baseline Chance Requests Currently in Process (\$000)}

\begin{tabular}{|l|c|c|c|c|c|c|c|c|c|}
\hline $\begin{array}{c}\text { PROJECT } \\
\text { CHANGE } \\
\text { NUMBER }\end{array}$ & $\begin{array}{c}\text { DATE } \\
\text { ORIGIN. }\end{array}$ & BCR TITLE & $\begin{array}{c}\text { FYo0 } \\
\text { COST } \\
\text { IMPACT } \\
\text { S000 }\end{array}$ & SCH & TECH & $\begin{array}{c}\text { DATE TO } \\
\text { CCB }\end{array}$ & $\begin{array}{c}\text { CCB } \\
\text { APR'VD }\end{array}$ & $\begin{array}{c}\text { RL } \\
\text { APR'VD }\end{array}$ & $\begin{array}{c}\text { CURRENT } \\
\text { STATUS }\end{array}$ \\
\hline & & Nothing to report at this time. & & & & & & \\
\hline
\end{tabular}

\section{ANALYTICAL SERVICES - WBS 1.2.4 Milestone ACHIEVEMENT}

\begin{tabular}{|r|r|r|c|r|r|r|r|r|}
\hline & \multicolumn{4}{|c|}{ FISCAL YEAR-TO-DATE } & \multicolumn{3}{c|}{ REMAINING SCHEDULED } & \\
\cline { 2 - 9 } MILESTONE TYPE & $\begin{array}{c}\text { Completed } \\
\text { Early }\end{array}$ & $\begin{array}{c}\text { Completed } \\
\text { On } \\
\text { Schedule }\end{array}$ & $\begin{array}{c}\text { Completed } \\
\text { Late }\end{array}$ & Overdue & $\begin{array}{c}\text { Forecast } \\
\text { Early }\end{array}$ & $\begin{array}{c}\text { Forecast } \\
\text { On } \\
\text { Schedule }\end{array}$ & $\begin{array}{c}\text { Forecast } \\
\text { Late }\end{array}$ & $\begin{array}{c}\text { TOTAL } \\
\text { FY 2000 }\end{array}$ \\
\hline Enforceable Agreement & 0 & 0 & 0 & 0 & 0 & 0 & 0 & 0 \\
\hline DOE-HO & 0 & 0 & 0 & 0 & 0 & 0 & 0 & 0 \\
\hline FO & 0 & 0 & 0 & 0 & 0 & 0 & 0 & 0 \\
\hline RL & 0 & 0 & 0 & 0 & 0 & 1 & 0 & 1 \\
\hline Total Project & 0 & 0 & 0 & 0 & 0 & 1 & 0 & 1 \\
\hline
\end{tabular}

\section{Tr-Party Aoreement / EA Milestones}

Nothing to report.

DNFSB Commitments

Nothing to report.

\section{MILESTONE EXCEPTION REPORT}

\begin{tabular}{|c|c|}
\hline Number/NWBS Level & Milestone Title \\
\hline
\end{tabular}

Overdue - 0

FORECAST LATE - 0 


\section{Performance Objectives}

FY 2000 RPP SUPPORT AEU PROCESSING (FDH-CP-I-I.A)
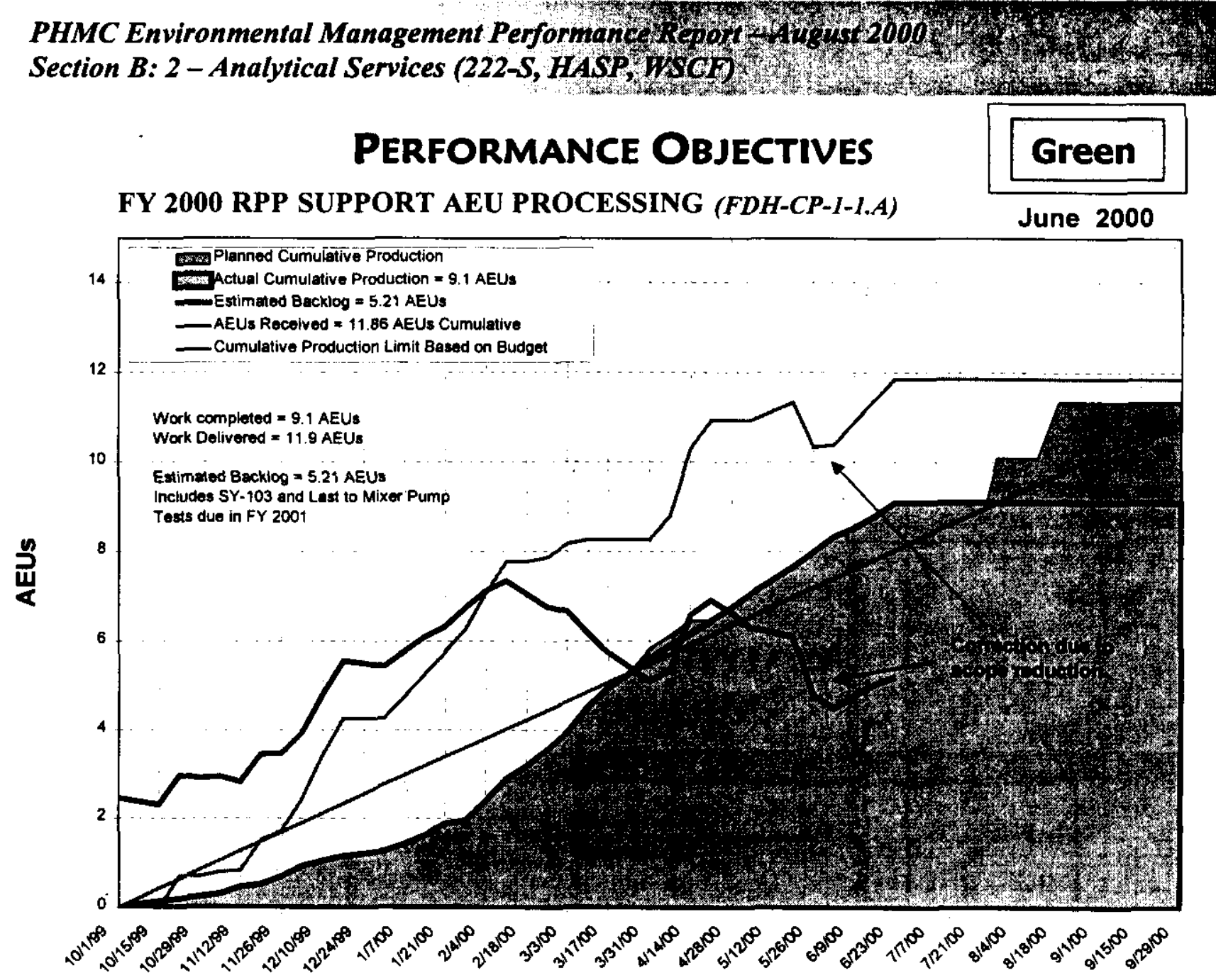

Continue working with RPP on 222-S laboratory production integration. Will meet the September 2000 commitment of eleven AEUs. Production through June 2000 is 9.1 AEUs, versus a planned 9.3 AEUs. Production through July 14, 2000 is 9.7 AEUs.

\section{KEY INTEGRATION ACTIVITIES}

- $\quad$ Continue to support ORP efforts to establish required analytical support for Waste Treatment Plant (WTP) operations.

- In the longer term, ORP could utilize unused space at WSCF for cold run test support and process laboratory analytical equipment testing.

- The 222-S laboratory, with some refurbishment, might become a low cost option to a new large-scale laboratory associated with the WTP.

- A white paper is being prepared for RPP to address the potential support that 222-S and WSCF could provide to the WTP. 


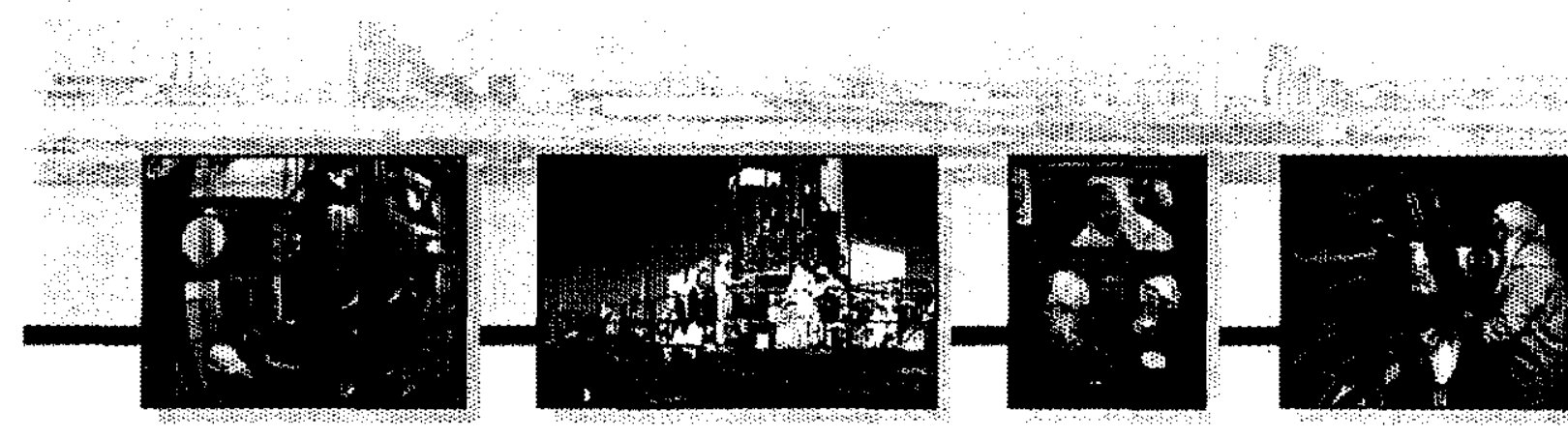

\section{Section C:1 Nuclear Material Stabilization}

\section{PROJECT MANAGERS P.M. Knollmeyer, RL (509) 376-7435}

G.W. Jackson, FH (509) 373-6622 


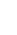




\section{SUMMARY}
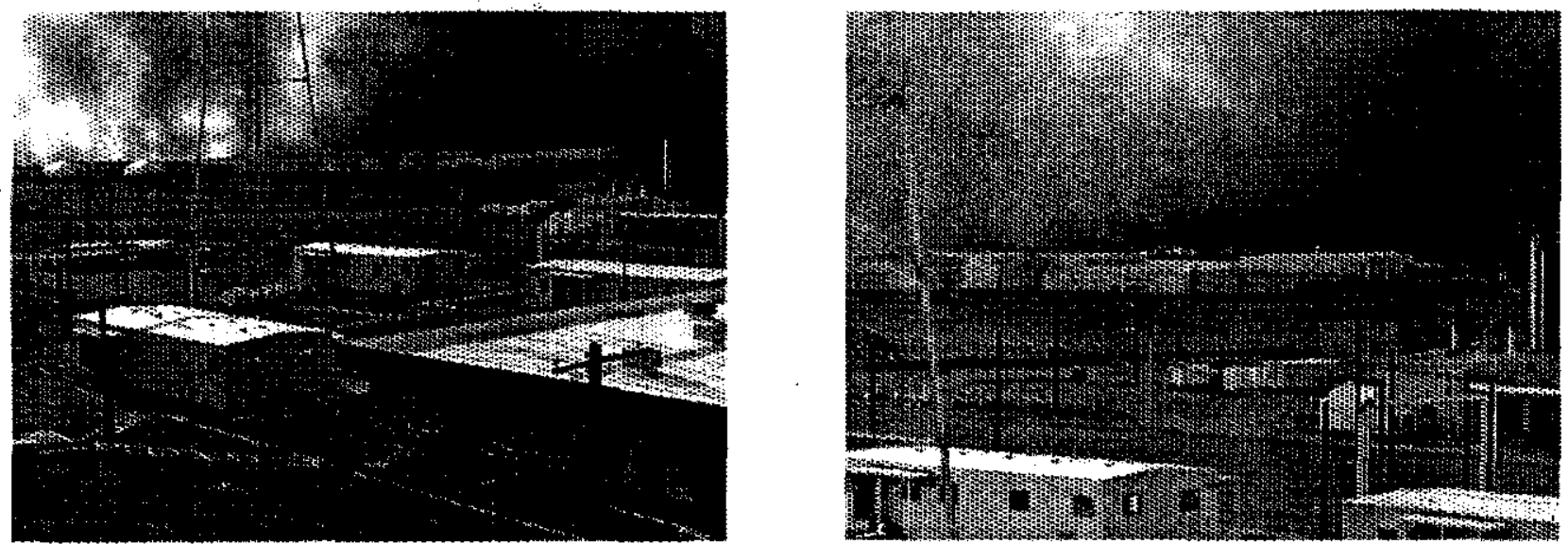

"The June 27-30 Hanford fire resulted in a \$1.3M impact to the Nuclear Materials Stabilization Project."

The Nuclear Material Stabilization mission consists of the Plutonium Finishing Plant (PFP), WBS 1.4.5, PBS TP05.

NOTE: Unless otherwise noted, the Safety, Conduct of Operations, Milestone Achievement, and Cost/Schedule data contained herein is as of June 30,2000. All other information is as of July 13,2000 unless otherwise stated.

As of July 13,2000 a total of 317 cans of Plutonium oxides and sludges have been stabilized through thermal stabilization (27 additional items since last report). A total of 13 liters of Plutonium nitrate solution have been stabilized in the prototype vertical denitration calciner [no change since December 1999 due to focus on $\mathrm{Mg}(\mathrm{OH})_{2}$ Precipitation Process installation activities].

As of July 13, 2000, there have been 227 days without a lost workday injury, attributed to following Integrated Safety Management System (ISMS) principles.

Fiscal-year-to-date milestone performance (EA, DOE-HQ, and RL) shows that three of ten milestones ( 30 percent) were completed on or ahead of schedule, one completed late ( 10 percent), and six ( 60 percent) are overdue. No milestones were scheduled for completion during this report period. Further details can be found in the milestone exception report following the cost and schedule variance analysis.

\section{ACCOMPLISHMENTS}

\section{Maintain Safe and Compliant PFP}

- As of July 13, 2000, there have been 227 days without a lost workday injury.

- Corrective actions for systematic items identified by the Deficiency Evaluation Group are being addressed and completed.

- Completed the Integrated Safety Management System (ISMS) verification process and presented subsequent briefing to DOE-RL. Results indicated there were no opportunities for improvement requiring immediate action. 
- Developed and completed initial Hanford Site fire recovery plan and assisted other facilities with their recovery plan development.

- Transferred heat source to electricity for plant sanitary water to reduce reliance on steam.

\section{Maintain Safe \& Secure SNM}

- Increased material transfers and Non Destructive Assays (NDA) to support enhanced thermal stabilization processing.

\section{Oxides/Metals/Polycubes Stabilization}

- Completed stabilization of 317 Plutonium (Pu) oxide items as of July 13,2000 including seven (7) oxidized metal items and four (4) oxides that were shipped offsite.

- Successfully restarted the stabilization process after the Hanford Site fire and subsequent material inventory.

\section{Solution Stabilization}

- Received RL approval of the Plan of Action for the $\mathrm{Mg}(\mathrm{OH})_{2}$ Operations Readiness Review (ORR).

\section{Residue Stabilization}

- Submitted revised Part A permit to Ecology to provide for RCRA permitted storage at the Plutonium Finishing Plant (PFP).

- Designation of Sand Slag and Crucible as debris eliminates WIPP sampling requirements.

- Completion of Notice of Construction review for Pipe-n-Go.

- Eighty-eight (88) Pipe Overpack Containers (POCs) are now ready for shipment to Hanford

- Repair of the existing foor in room 1920 was successfully completed July 17, 2000 avoiding impact to schedule, radiological concerns, and waste disposal costs. The epoxy coating used in lieu of removal and replacement of the floor, resulted in a cost savings of approximately $\$ 220,000$.

\section{Project $W-460$}

- Approval of the Notice of Construction (NOC) for the 234-5 Bagless Transfer System (BTS) was received from the Washington State Department of Health.

- Completed RL revalidation of Project W-460-authorizing funding for F $Y 2002$.

- Rl approved Critical Decision \#2, to complete design and long lead procurement, for project W-460.

\section{SAFETY}

Lost Away Workday Case Rate has had a significant decrease, with 11 of 12 months in a row below average. Current rate is exceptionally low. Occupational Safety and Health Act (OSHA) recordable case rate has significantly improved in comparison to the adverse trend of Spring 1999.

FY 2000 OSHA case rate and DOE Safety Cost Index are very favorable. DOF Safety Cost Index has been six months in a row below average. The Index has both a new average and control limits reflecting the significant decrease noted earlier in the year. 
12. Lost Away Workday Case Rate

$10:$

Cases per 200,000 hours
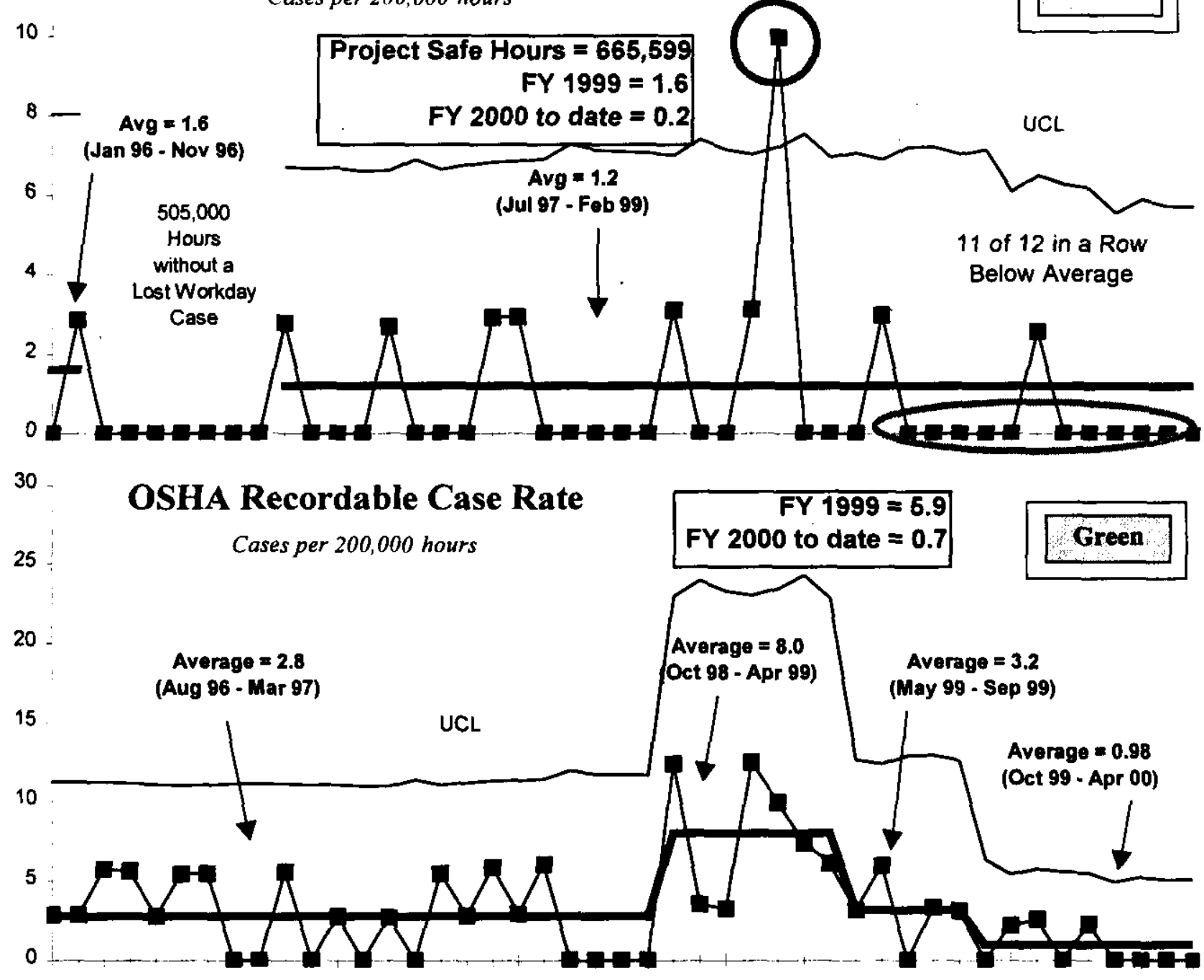

400 DOE Safety Cost Index

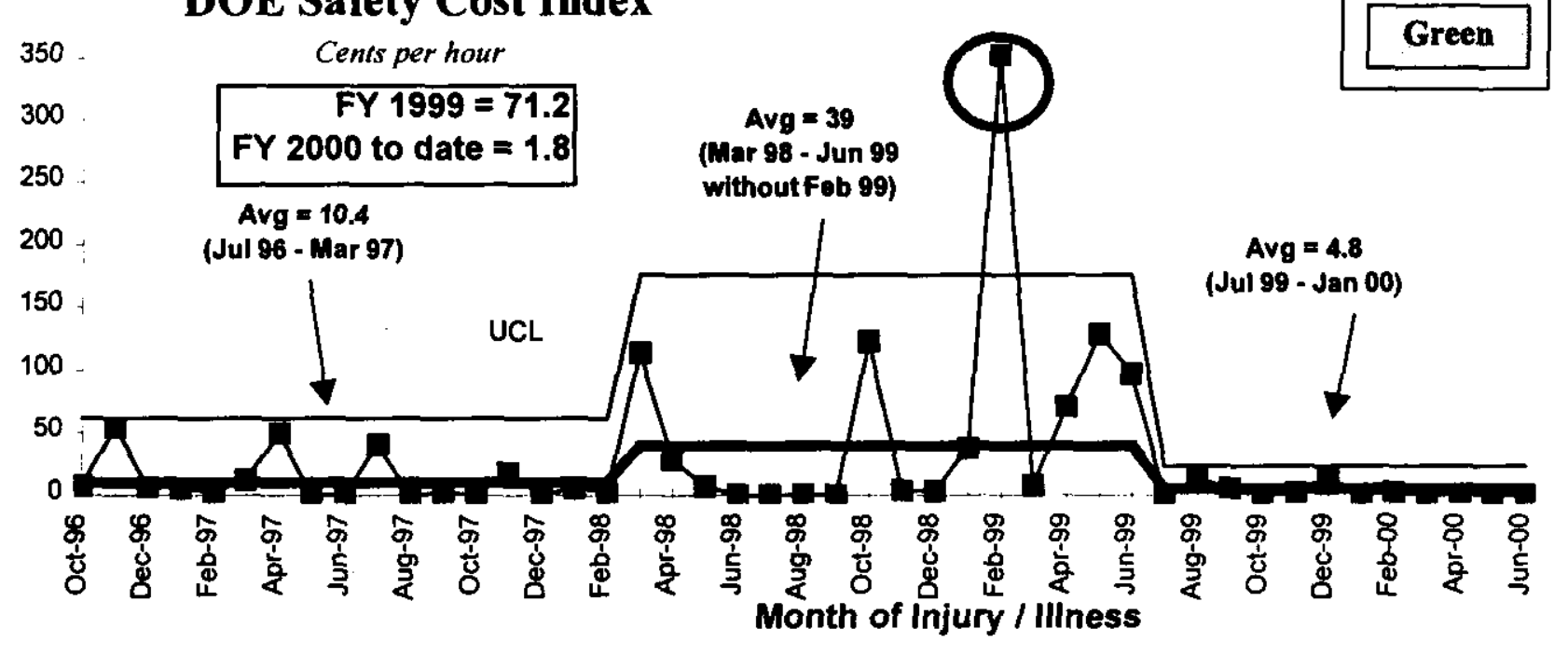




\section{CONDUCT OF OPERATIONS / ISMS STATUS CONDUCT OF OPERATIONS Events per 200,000 Hours}

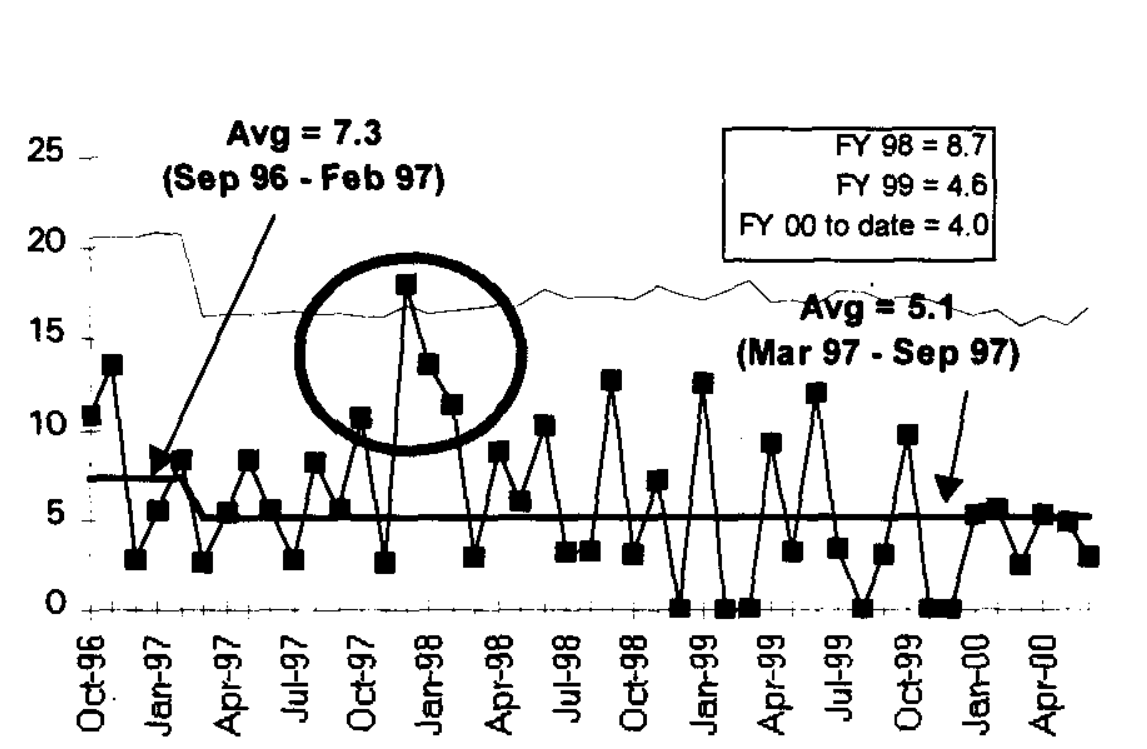

\section{ISMS STATUS}

Green

No. of Reports

Past 12 Months

- NMS project has met the objectives established for Phase II ISMS verification.

\section{BREAKTHROUGHS / OPPORTUNITIES FOR IMPROVEMENT}

\section{Breakthroughs}

- WIPP-Validated NDA System -- Implementation of a Waste Isolation Pilot Plant (WIPP) "validated" plutonium-measuring NDA system in FY 2000 continues. The equipment necessary to upgrade the Segmented Gamma Scanner has been delivered and upgrades have been initiated.

- $\quad$ Time/Temperature Test Results for PFP Thermal Stabilization Furnaces - This document provides the test results of the process currently used at the Plutonium Finishing Plant (PFP) for producing stable plutonium dioxide. The testing results show that the materials fed into the furnaces are being heated to at least $950^{\circ} \mathrm{C}$ for at least two hours as required by the Department of Energy Standard 3013-99.

Green

- $\quad$ Rocky Flats Ash - Identification of existing Rocky Flats ash sources that should eliminate the need to fabricate new-segmented gamma scanner source standards. 


\section{Opportunities for Improvement}

- Project Baseline Control - A number of cost control measures are in place, and actively managed, to mitigate the current budget deficit.

These include reductions in contract costs, overtime, material procurements, and suspension of non-critical hiring.

- $\quad$ Exposure Reduction - Methods are being implemented to reduce exposure to $2736-\mathrm{ZB}$ vault staff. These As Low As

Reasonably Achievable (ALARA) reduction methods include: remote surveillance (robotic), additional shielding, and full scale mock up vault cubicles.

- $\quad$ Second Brazilian Thorium Sludge (BTS) and Outer Can

Welder for Project W-460- Discussions are underway with

Green

Westinghouse Savannah River Company to provide an accelerated delivery date for the Second BTS and Outer Can Welder for Project W-460. Funding has been allocated to Savannah River for design, construction, and delivery of the outer can welder.

- Preventive Maintenance/Surveillance Activities - A recovery plan is being developed to reduce the backlog caused by the Hanford Site fire.

\section{UPCOMING ACTIVITIES}

- Begin Pu solution stabilization via $\mathrm{Mg}(\mathrm{OH})_{2}$ in September 2000.

- $\quad$ Complete glovebox installation in July 2000.

- Complete ORR and training activities for stabilization activities in room 230-C in September 2000.

- $\quad$ Startup Residues operations in fourth quarter of FY 2000.

- $\quad$ Complete installation and startup of the 234-5Z Bagless Transfer System (BTS) in fourth quarter of FY 2000.

- $\quad$ Begin metal stabilization processing in November 2000 .

- Initiate polycube stabilization in first quarter of FY 2001 . 


\section{Cost Performance ( $\$ M):$}

\begin{tabular}{|l|c|c|c|}
\hline & BCWP & ACWP & VARIANCE \\
\hline Nuclear Material Stabilization & $\$ 80.0$ & $\$ 89.7$ & $(-\$ 9.6)$ \\
\hline
\end{tabular}

The $\$ 9.6$ million (12 percent) unfavorable cost variance is mostly driven by overruns in Solution Stabilization, Maintenance, and Training. Increased resources for the $\mathrm{Mg}(\mathrm{OH})_{2}$ glovebox design, procurement and installation have been necessary to maintain the aggressive schedule demands. The cost overruns are somewhat offset by underruns in other areas due to a shortage of staff.

\section{Schedule Performance (\$M):}

\begin{tabular}{|l|c|c|c|}
\hline & BCWP & BCWS & VARIANCE \\
\hline Nuclear Material Stabilization & $\$ 80.0$ & $\$ 94.7$ & $(-\$ 14.7)$ \\
\hline
\end{tabular}

The $\$ 14.7$ million (15 percent) unfavorable schedule variance is due to the behind status on Project W-460, the Plutonium Stabilization and Packaging System, capital activities, such as the elimination of trailers and vault modification design. Facility construction modifications have not started as scheduled due to deviations in the definitive design, required changes to the National Environmental Policy Act (NEPA) Supplemental Analysis and approval of the Notice of Construction by the Washington State Department of Health. Residues and solution stabilization activities are also the behind schedule. Solution stabilization construction activities are two months behind schedule, with startup now planned for September 2000. Restart activities for residues are behind schedule and additional NDA equipment necessary for WIPP validation has been ordered. Restart of residue disposition activities (i.e., Pipe-n-Go of ash) is now anticipated in the fourth quarter of FY 2000, versus the planned April 2000 restart. Oxide stabilization activities continue significantly ahead of schedule.

\section{FY 2000 Cost/Schedule Performance - All. Fund Types Cumulative to Date Status - $(\$ 000)$}

\begin{tabular}{|c|c|c|c|c|c|c|c|c|c|c|}
\hline & & \multicolumn{7}{|c|}{ FYTO } & \multicolumn{2}{|c|}{ L } \\
\hline \multicolumn{2}{|c|}{ By PBS } & Bcws & BCWP & ACWP & sv & $\%$ & cV & $\%$ & PEM & EAC \\
\hline \multirow[t]{2}{*}{$\begin{array}{l}\text { WBS } 1.4 .5 \\
\text { PBS TP05 }\end{array}$} & $\begin{array}{l}\text { PFP } \\
\text { Deactivation }\end{array}$ & \$ 94,711 & $\$ 80,038$ & S 89,675 & $\$(14,674)$ & $-15 \%$ & S $(9,637)$ & $-12 \%$ & $\$ 124,750$ & \$ 122,994 \\
\hline & Total & $\$ 94,711$ & $\$ 80,038$ & $\$ 89,675$ & $\$(14,674)$ & $-15 \%$ & $\$(9,637)$ & $-12 \%$ & $\$ 124,750$ & $\$ 122,994$ \\
\hline
\end{tabular}

RL-Directed costs (steam) are included in the PEM BCWS. 


\section{Cost/SChedule Performance Indices (MONTHLY AND FYTD)}

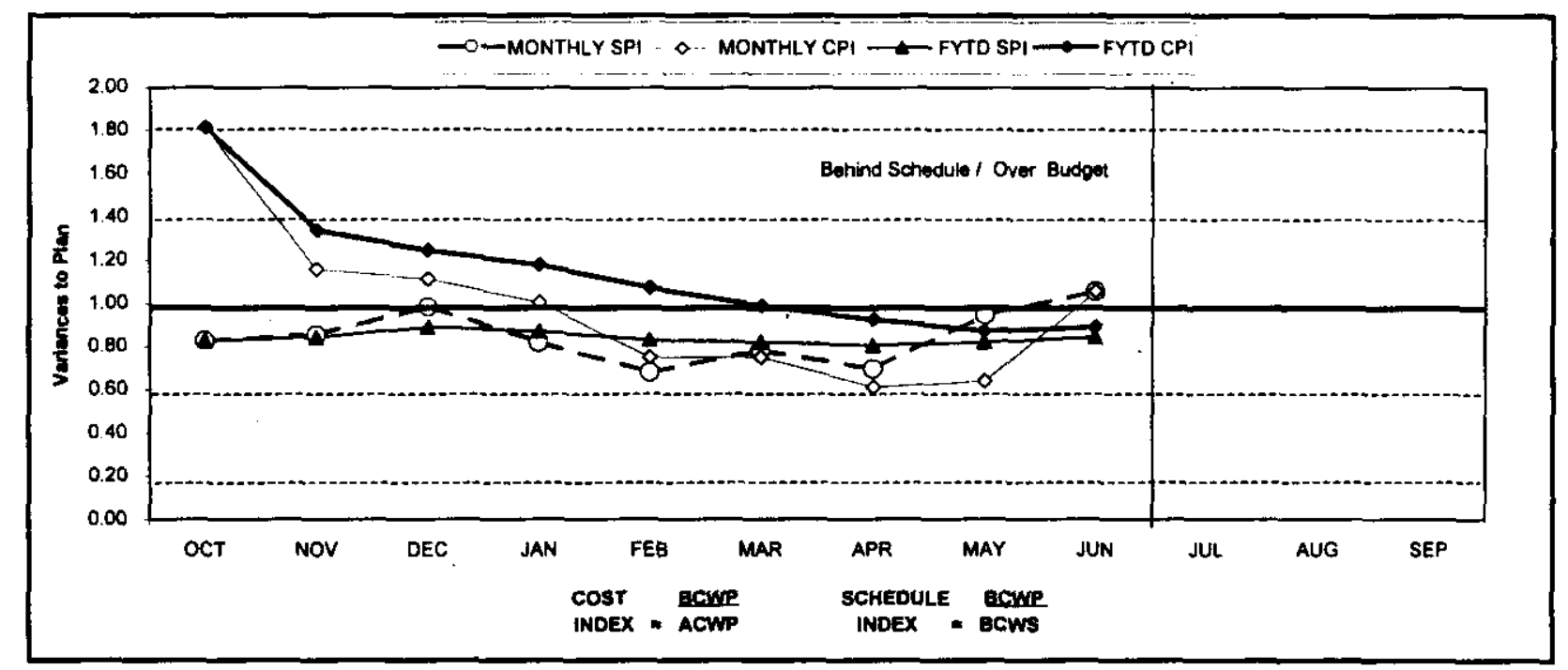

\begin{tabular}{|c|c|c|c|c|c|c|c|c|c|c|c|c|}
\hline FY 2000 & OCT & NOV & DEC & JAN & FEB & MAR & APR & MAY & JUN & JUL & AUG & SEP \\
\hline MONTHLY SPI & 0.83 & 0.85 & 0.98 & 0.82 & 0.68 & 0.78 & 0.70 & 0.95 & 1.06 & & & \\
\hline MONTHLY CPI & 1.81 & 1.16 & 1.11 & 1.01 & 0.75 & 0.75 & 0.61 & 0.64 & 1.06 & & & \\
\hline FYTD SPI & 0.83 & 0.84 & 0.89 & 0.87 & 0.83 & 0.82 & 0.81 & 0.82 & 0.85 & & & \\
\hline FYTD CPI & 1.81 & 1.34 & 1.25 & 1.18 & 1.07 & 0.99 & 0.93 & 0.87 & 0.89 & & & \\
\hline MONTHLY BCWS & 57,913 & 512.725 & 59,999 & 510,540 & $\$ 11,128$ & $\$ 13,401$ & 59,632 & 59,999 & $\$ 9,375$ & 59,170 & 511,161 & 59,707 \\
\hline MONTHLY BCWP & $\$ 6.543$ & 510,873 & 59,849 & 59,638 & 57,567 & $\$ 10,480$ & 56,704 & 59,474 & $\$ 9,910$ & & & \\
\hline MONTHLY ACWP & 53,613 & 59.386 & $\$ 8,845$ & 58,587 & $\$ 10,085$ & $\$ 13,961$ & $510, \overline{988}$ & $\$ 14,826$ & 59,383 & & & \\
\hline FYTD BCWS & 57,913 & 520,638 & 530,637 & $\$ 41,177$ & $\$ 32,305$ & 565,706 & 575,338 & 585,336 & 594,711 & 5103,882 & 5115,043 & $\$ 124,750$ \\
\hline FYTD BCWP & 56,543 & 517,416 & $\$ 27,265$ & $\$ 35,903$ & $\$ 43,470$ & 553,950 & 560.654 & 570,128 & 580,038 & & & \\
\hline FYTD ACWP & 53,613 & $\$ 12,999$ & 521,844 & $\$ 30,431$ & $\$ 40,516$ & 554,477 & 565.465 & $\$ 80,292$ & $\$ 89,675$ & & & \\
\hline
\end{tabular}

\section{COST VARIANCE ANALYSIS: $(-\$ 9.6 \mathrm{M})$}

\section{$\underline{\text { WBS/PBS }}$}

\subsection{3/TP05} needed for procurement and installation of the $\mathrm{Mg}(\mathrm{OH})_{2}$ glovebox and equipment, and other construction activities, and use of subcontract staff augmentation.

Impact: Construction not started on time; cost overruns can hurt overall plant project funding. Corrective Action: Acceleration of schedule for procurement, construction is now complete and startup has been implemented.

\subsection{5/TP05 Transition PFP (-\$0.4M)}

Description and Cause: Carryover scope from FY99 (Sampling follow-on, NDA); unforeseen lab costs due to PCBs; evaluation of remedial alternatives Impact: Deferred tank characterization until FY 2001, no major impact identified.

Corrective Action: BCR funding $\$ 395 \mathrm{~K}$, using FY 1999 carryover funds was implemented this month creating the positive cost variance. Balance is on funds management. Stopped work on largest remaining contract, minimal effort and cost for balance of FY. 


\subsection{2/TP05 PFP Fee Allocation (-S.9M)}

Description and Cause: Unfavorable cost variance due to point adjustment $(-\$ 471 \mathrm{~K})$ in May to adjust for delay in staff hiring ramp-up at the beginning of FY 2000. An increase in the fee accrual rate from 90 percent to 100 percent also is a contributory factor.

Impact: No impact.

Corrective Action: None required.

\section{SCHEDUle VARIANCE ANALYSIS: $(-\$ 14.7 M)$}

\section{WBS/PBS}

1.4.5.1.14/TP05 Item Project W-460, Plutonium Stabilization and Packaging System, definitive design and construction. Facility construction modifications have not yet started as scheduled, due to deviations to the Definitive Design, required changes to the NEPA Supplement Analysis and approval of the Notice of Construction (NOC) by the Washington State Department of Health (WSDOH).

Impact: Potential delay in the startup of the Bagless Transfer and Stabilization system in 2736-ZB, which can impact stabilization activities in FY 2001.

Corrective Action: To assist in the recovery, a second BTS unit is being installed in the 234-5Z facility, which will enable BTS unit operation in FY 2000 as originally planned. Project W-460 management and WSDOH staffs are aggressively working to approve the NOC, which will enable construction to begin.

\subsection{3/TP05 Stabilize SNM (-\$5.3M)}

Description and Cause: The unfavorable schedule variance is due to the behind status on Project W-460, the Plutonium Stabilization and Packaging System, capital activities, such as the elimination of trailers and vault modification design. Facility construction modifications have not started as scheduled due to deviations in the definitive design, required changes to the NEPA Supplemental Analysis and approval of the Notice of Construction by the WSDOH. The negative schedule variance is also due to the behind schedule status on residues and solution stabilization activities. Solution stabilization construction activities are two months behind schedule, with startup now planned for September 2000. Restart activities for residues are behind schedule and the need for additional NDA equipment necessary for Waste Isolation Pilot Plant (WIPP) validation has been ordered. Restart of residues is now anticipated in August of FY 2000, versus the planned April 2000 restart. Oxide stabilization activities continue significantly ahead of schedule.

Impact: Potential delay in the startup of the Bagless Transfer and Stabilization System in 2736ZB which could impact stabilization activities in FY 2001.

Corrective Action: To assist in the recovery, a second BTS unit is being installed in the 234-5Z facility, which will enable BTS unit operation in FY 2000 as planned. 


\section{FUNDS MANAGEMENT FUNDS VS. SPENDING FORECAST $(\$ 000)$ FY TO DATE THROUGH JUNE 2000 (FLUOR HANFORD, INC. ONLY)}

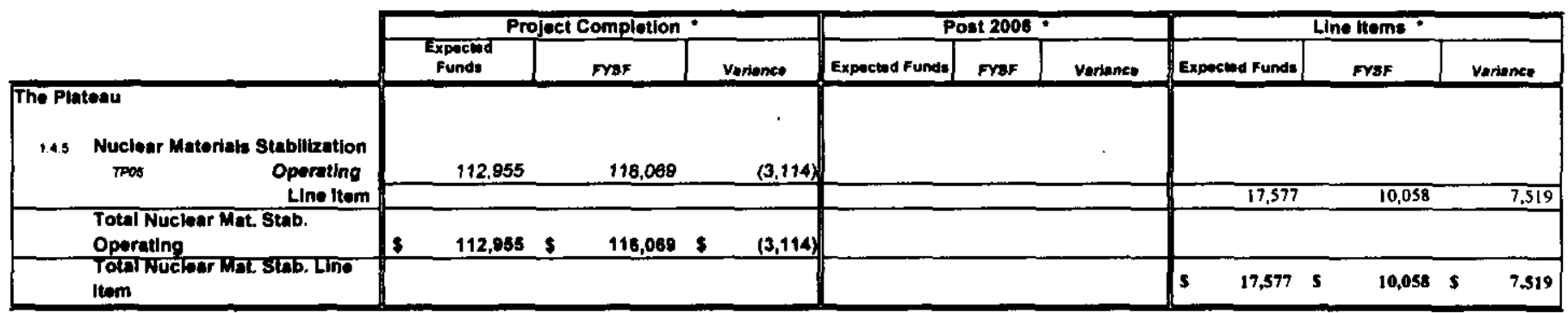

- Control Point

\section{Technical Issues}

\section{ISSUES}

Sixty-three (63) items have not met Loss On Ignition criteria for repackaging. Impact: Reprocessing/retest of material could potentially impact the overall processing schedule and increase employee dose rates.

Corrective Action: A supercritical fluid extraction system designed specifically for moisture measurements has been purchased and is expected to be operational in September, 2000 .

\section{DOE/Regulator/External Issues}

- $\quad$ RCRA Permitting Part A revision for adding ignitability waste code was submitted to Ecology in support of Cementation startup.

- RCRA Permitting in support of Pipe-N-Go:

- A revised Notice of Intent (NOI) to define storage locations at Plutonium Finishing Plant (PFP) was released for public review.

- The required interim status Cementation documents, necessary to work under a Part A RCRA permit, have been completed and were submitted by RL to Ecology on July 20, 2000. These documents include inspection, waste analysis, training, emergency/contingency and closure plans.Revised Part $\mathrm{A}$ to provide permitted storage at PFP has been transmitted to Ecology. Approval of Part A by Ecology is required prior to startup.

- Update interface agreement between PFP and Waste Management to define requirements and responsibilities to support CWC and Waste Isolation Pilot Plant acceptance of packaged residues. 
- $\quad$ The PFP has requested DOE-RL to assist in expediting development of the Safety Analysis for Packaging Report (SARP) or Safety Evaluation for Packaging (SEP) required for transporting pipe overpack containers (POCs) from PFP to the Central Waste Complex.

\section{Baseline Change Requests Currently in Process}

\begin{tabular}{|c|c|c|c|c|c|c|c|c|c|}
\hline $\begin{array}{l}\text { PROMECT } \\
\text { CHANGE } \\
\text { NUMBER }\end{array}$ & $\begin{array}{c}\text { DATE } \\
\text { ORIGINAL }\end{array}$ & $\begin{array}{l}\text { BASELINE CHANGE REQUEST } \\
\text { TITLE }\end{array}$ & $\begin{array}{l}\text { COST } \\
\text { IMPACT } \\
\text { (S000s) }\end{array}$ & SCH & TECH & $\begin{array}{l}\text { DATE TO } \\
\text { FHI CCB }\end{array}$ & $\begin{array}{c}\text { CCB } \\
\text { APR'VD }\end{array}$ & RL APR'VD & CURRENT STATUS \\
\hline FSP22000-001 & 13-0ct-99 & $\begin{array}{l}\text { Deicte TRP-99-419, Complete Instal. } \\
\text { of Production Scale Vertical Calciner }\end{array}$ & 250 & & & & & & On hold \\
\hline FSP:2000-005 & $30-$ Nov- 99 & $\begin{array}{l}\text { Templement PFP Int Proj Mgerm Pan } \\
\text { Addendum I }\end{array}$ & 5659 & $x$ & $\mathrm{x}$ & & & & Tn work \\
\hline FSP-2000-032 & 5-Aprovo & 2nd Bagless Transier System at PFP & (\$1,500) & $\mathbf{x}$ & $x$ & $6-A p r-00$ & 7-Apr-do of & T6-jun-00 & Complete \\
\hline FSP:2000-043 & T-May-00 & Video Control Camera & 350 & $\mathrm{x}$ & $\mathrm{x}$ & & & & $\begin{array}{l}\text { On hold due to budget } \\
\text { constraints }\end{array}$ \\
\hline FSP-2000-049 & 8-Jun-00 & $\begin{array}{l}\text { Submit hantord. Materals Forecast to } \\
\text { RL } \\
\text { TRP-00-103 date) }\end{array}$ & & $\mathbf{X}$ & & T6-Jun-00 & 2I-Jun-00 & & At DOE-RL for approval \\
\hline FSP-2000-050 & 9-Jun- -00 & $\begin{array}{l}\text { W-460; procure calorimeters/outer } \\
\text { can welder }\end{array}$ & $\mathbf{5 2 , 6 0 0}$ & $\mathbf{X}$ & $\mathrm{x}$ & T6-Jun-00 & & & At FHTCCB for approval \\
\hline FSP-2000-05T & 16-3un-00 & HEPA Fiter Vutherability Assesment & 538 & $\mathrm{X}$ & $\mathbf{x}$ & & & & Tn Work \\
\hline FSP-2000-033 & T-May-00 & Backtlow Preventers & $\$ 160$ & $\mathbf{x}$ & $x$ & & & & Tn work \\
\hline FSP-2000-045 & $30-$ Nov-99 & $\begin{array}{l}\text { Implement PFP Tnt Proj Mgmi Plan } \\
\text { Addendum l }\end{array}$ & 30 & $\mathbf{X}$ & $\bar{x}$ & & & & In work at PFP \\
\hline
\end{tabular}

\section{Milestone ACHievement}

\begin{tabular}{|c|c|c|c|c|c|c|c|c|}
\hline \multirow[b]{2}{*}{ MILESTONE TYPE } & \multicolumn{4}{|c|}{ FISCAL YEAR-TO-DATE } & \multicolumn{3}{|c|}{ REMAINING SCHEDULED } & \multirow[b]{2}{*}{$\begin{array}{l}\text { TOTAL } \\
\text { FY } 2000\end{array}$} \\
\hline & $\begin{array}{c}\text { Completed } \\
\text { Early }\end{array}$ & $\begin{array}{l}\text { Completed } \\
\text { On } \\
\text { Schedule }\end{array}$ & $\begin{array}{l}\text { Completed } \\
\text { Late }\end{array}$ & Overdue & $\begin{array}{c}\text { Forecast } \\
\text { Early }\end{array}$ & $\begin{array}{l}\text { Forecast } \\
\text { On } \\
\text { Schedule }\end{array}$ & $\begin{array}{c}\text { Forecast } \\
\text { Late }\end{array}$ & \\
\hline Enforceable Agreement & 1 & 1 & 0 & $\overline{0}$ & $\overline{0}$ & 0 & $\overline{0}$ & 2 \\
\hline DOE-HQ & 0 & 0 & 0 & 1 & 0 & 0 & 0 & 1 \\
\hline$\overline{R L}$ & $\overline{1}$ & 0 & 1 & 5 & 0 & 4 & 0 & 11 \\
\hline Total Project & 2 & 1 & 1 & 6 & 0 & $\overline{4}$ & 0 & 14 \\
\hline
\end{tabular}


PHMC Environmental Management Performance Report-August 2000

Section C: 1 - Nuclear Material Stabilization

Tri-Party Agreement / EA Milestones

Tri-Party Agreement Milestone M-15-37A (TRP-00-501), "Deliver Two (2)

Tank Z-241-Z-361 Core Samples to 222-S", due 10/30/99

Green

- $\quad$ Completed 1 month early (9/28/99)

Tri-Party Agreement Milestone (TRP-00-511), "Deliver Two (2)

Tank 241-Z-361 Core Sample Validated Data Packages to EPA", due 5/31/00

Green

- $\quad$ Completed On Schedule

\section{DNFSB Commitments}

DNFSB Milestone IP-113 (TRP-00-500), “Install 2 LANL Pyrolysis Units for Stabilization of Polycubes at PFP", due $12 / 31 / 99$

Green

- $\quad$ A BCR to remove pyrolysis stabilization of polycubes and implement thermal stabilization in its stead has been approved by $\mathrm{RL}$ and implemented into the baseline.

\section{MILESTONE EXCEPTION REPORT}

Number/WBS Level

OVERDUe - 6

TRP-00-103 RL

\subsection{6}

Submit Hanford Materials Forecast to

DOE-RL

Baseline Forecast Date Date

\section{$05 / 15 / 00 \quad 06 / 02 / 00$}

Cause: RL established a later completion date of June 16.

Corrective Action: A BCR has been prepared to change the baseline date to June 16. The milestone was completed on June 2.

\section{$\begin{array}{llll}\text { TRP-00-504 RL } & \text { Restart Cementation Operations } & 04 / 21 / 00 & \text { FY } 2001\end{array}$}

\subsection{5}

Cause: Stabilization processing has been re-sequenced.

Corrective Action: None, as the global stabilization end point will remain the same.

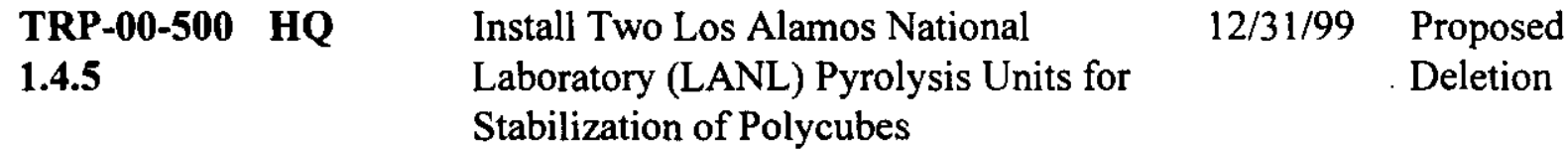

Cause: See DNFSB Commitment above.

Corrective Action: A BCR to remove pyrolysis stabilization of polycubes and implement thermal stabilization in its stead has been approved by RL and implemented into the baseline. However, this is a HQ milestone and cannot be removed from the list. 
TRP-00-510 RL Complete Annual Revision to IPMP $\quad$ 05/31/00 07/31/00

\subsection{5}

Cause: Comment resolution has taken longer than anticipated.

Corrective Action: None.

$\begin{array}{llll}\text { TRP-00-508 RL } & \begin{array}{l}\text { Complete } 2 \text { of } 5 \text { Criticality Alarm Panel } \\ \text { (CAP) Upgrades }\end{array} & 06 / 30 / 00 & \begin{array}{l}\text { Proposed } \\ \text { Deletion }\end{array}\end{array}$

Cause: Pending deletion upon approval of Baseline Change Request

Corrective Action: None

TRP-00-502 RL Complete Criticality Analysis \& Issue 06/30/00 07/31/00

\subsubsection{Spec. for Metal Processing}

Cause: Delayed by higher priority solutions analysis.

Corrective Action: None

\section{FY 1999 OVERDUE - 2}

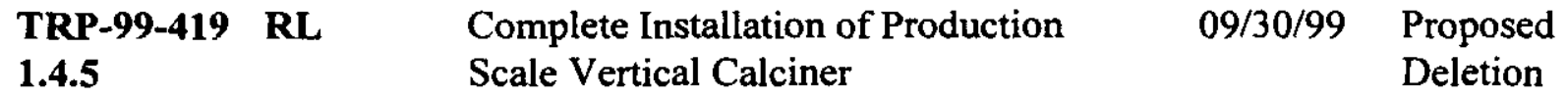

Cause: The production scale vertical calciner has been replaced with the Magnesium Hydroxide Precipitation process.

Impact: No impact. This milestone is obsolete.

Corrective Action: Since installation and testing of the production scale vertical calciner is an EM-65 Management Commitment, the Department of Energy, Richland Office (DOE-RL) change control process cannot remove this milestone.
TRP-99-500 HQ
Complete Installation \& Testing of
$09 / 30 / 99$
Proposed
1.4.5
Production Vertical Calciner
Deletion

Cause: The production scale vertical calciner has been replaced with the Magnesium Hydroxide Precipitation process.

Impact: No impact. This milestone is obsolete.

Corrective Action: Since this milestone is a DOE-HQ milestone and is part of the DOE-HQ 1998 DNFSB Recommendation 94-1 Implementation Plan, the Department of Energy, Richland Office change control process cannot remove this milestone. However, this milestone will be removed upon approval of the revised DOE-HQ DNFSB Recommendation 94-1 Implementation Plan. 


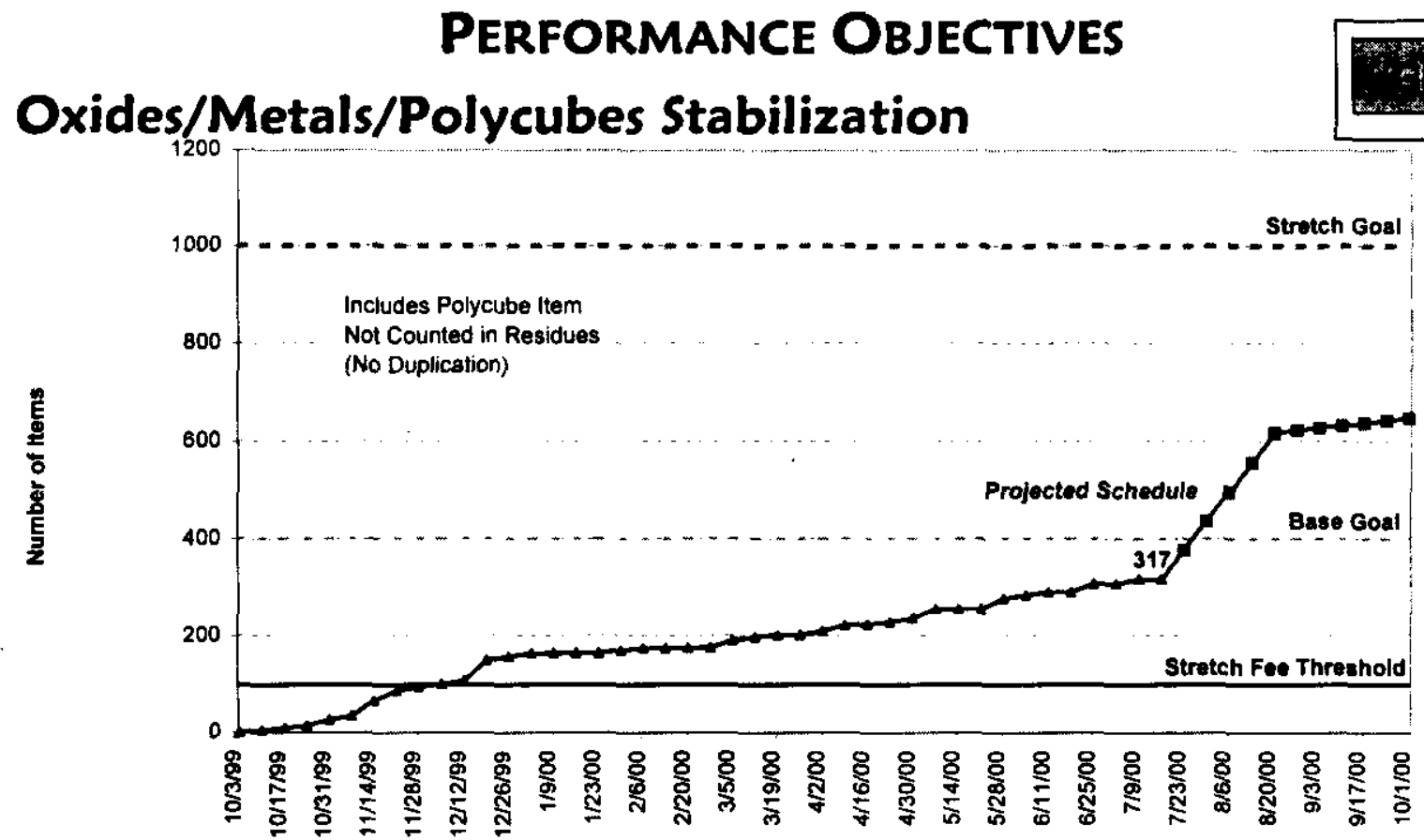

\begin{tabular}{|c|c|c|c|c|c|c|c|c|c|c|c|c|c|c|c|c|c|c|c|c|c|c|c|c|}
\hline & \multirow{2}{*}{\multicolumn{4}{|c|}{$10 / 3: 10 / 17,10 / 3111 / 21$}} & \multirow{2}{*}{\multicolumn{2}{|c|}{$12 / 5 \cdot 12 / 19$}} & \multirow{2}{*}{\multicolumn{2}{|c|}{$1 / 2 \cdot 1 / 16$}} & \multirow[b]{2}{*}{28} & \multirow[b]{2}{*}{2220} & \multirow[b]{2}{*}{$3 / 5$} & \multirow[b]{2}{*}{$\overrightarrow{3 / 19}$} & & \multirow[b]{2}{*}{$5 / 7$} & & \multirow{2}{*}{\multicolumn{2}{|c|}{2579}} & \multirow{2}{*}{\multicolumn{2}{|c|}{$7 / 23$}} & \multirow{2}{*}{\multicolumn{2}{|c|}{$10^{\circ}$}} & \multirow[b]{2}{*}{$2 / 24$} \\
\hline & & & & & & & & & & & & & $4 / 9$ & $\sqrt{1 / 23}$ & & $5 / 21$ & $8 / 4$ & & & & & & & \\
\hline & 1000 & 1000 & 1000 & 1000 & 1000 & 1000 & 1000 & 1000 & 1000 & 1000 & 1000 & 1000 & 1000 & 1000 & 1000 & 1000 & 1000 & 1000 & 1000 & 1000 & 1000 & $1000^{\circ}$ & 1000 & 1000 \\
\hline Oxides Bese Gool & 400 & 400 & 400 & 400 & 400 & 400 & 400 & $400 !$ & 400 & 400 & 400 & 400 & $400^{\circ}$ & 400 & 400 & 400 & 400 & 400 & 400 & 400 & $400^{\circ}$ & 400 : & 400 & 400 \\
\hline Oxides Actual & 0 & 10 & 27 & 87 & 101 & 148 & 164 & 164 & 974 & 174 & 189 & 201 & 221 & 228 & 255 & 255 & 284 & 307 & 317 & & & & & \\
\hline Dxides Projected Schedul & & & & & & & & & & & & & & & & & & & & 377 & 487 & 617 & 632 & 642 \\
\hline Stretch Foe Throuhold & 100 & 100 & $100^{\circ}$ & 100 & 100 & 100 & 100 & 100 & 100 & 100 & 100 & 100 & 100 & 100 & 100 & 100 & 100 & 100 & 100 & 100 & 100 & 100 & 100 & $\overline{100}$ \\
\hline
\end{tabular}

\section{Solution Stabilization}

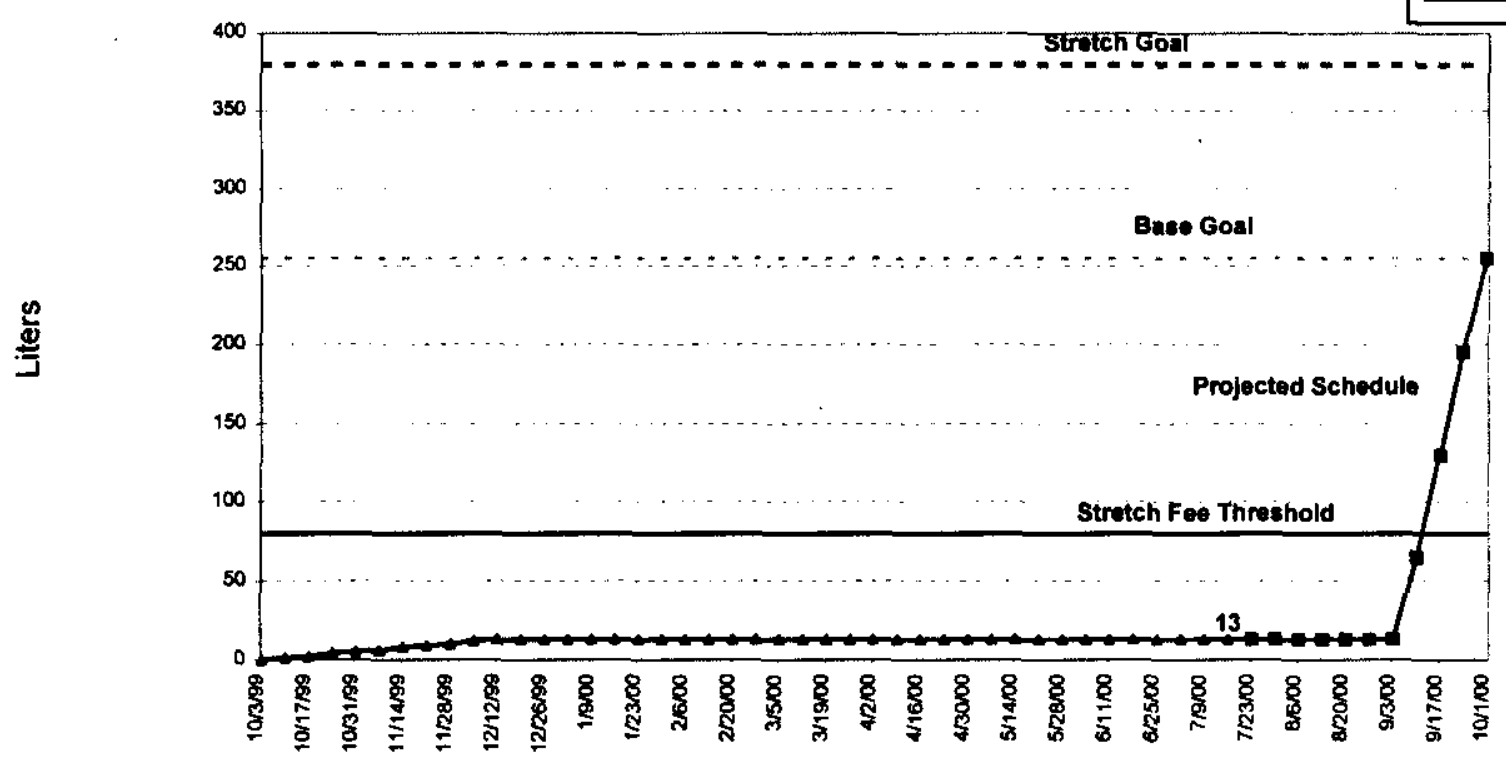

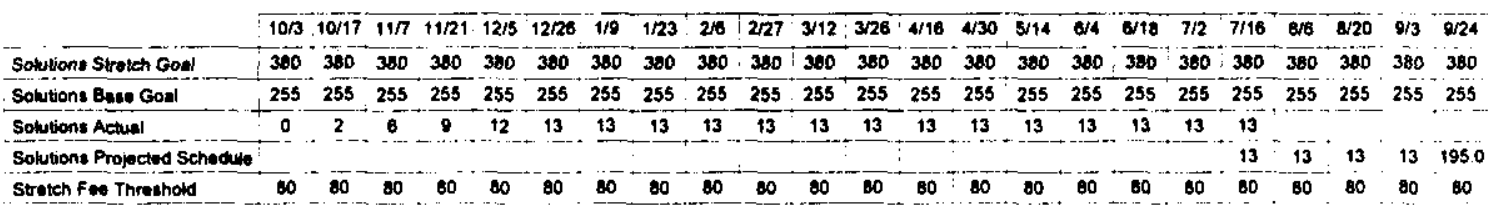

Aggressively pursuing construction completion in support of stabilization activities. 


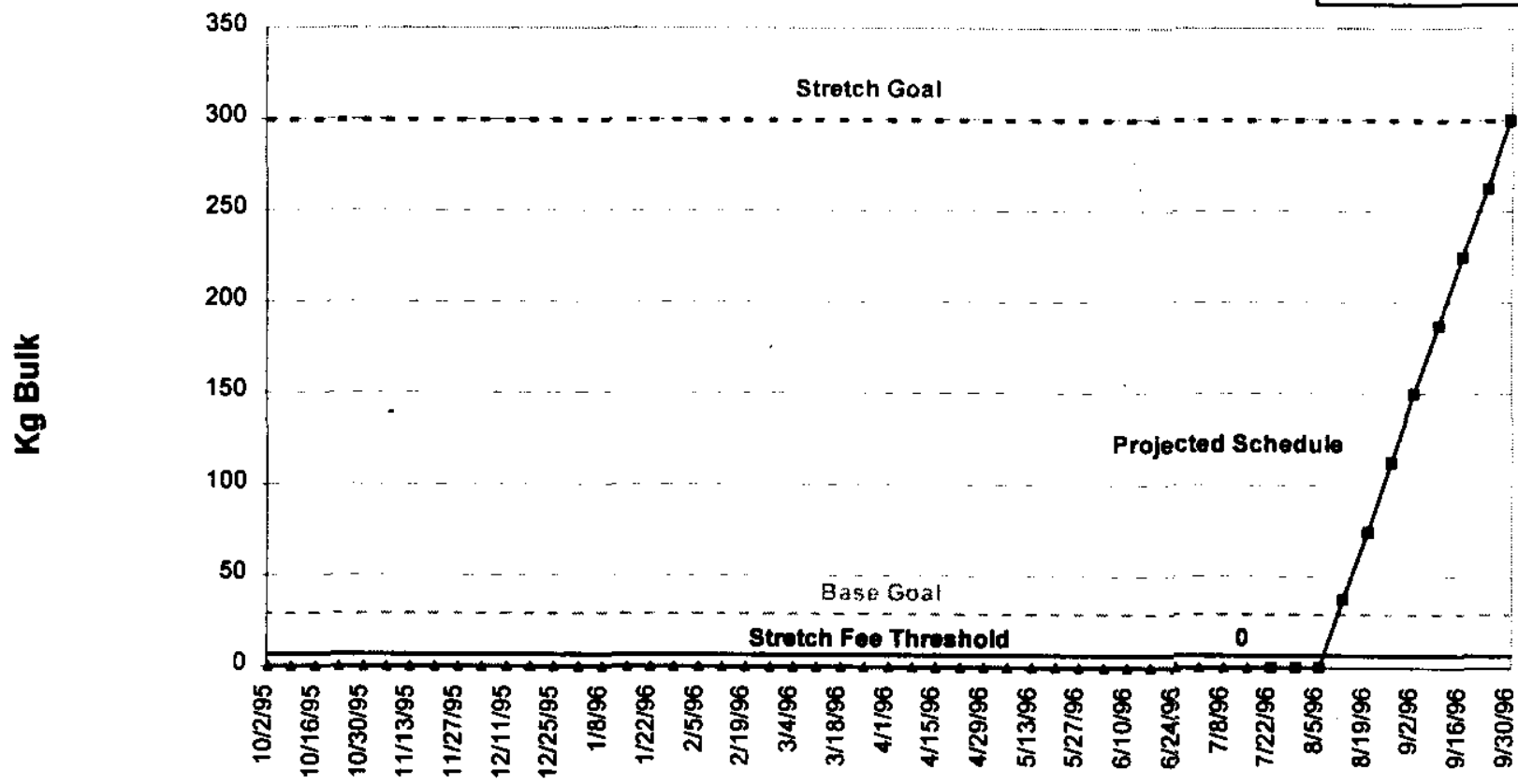

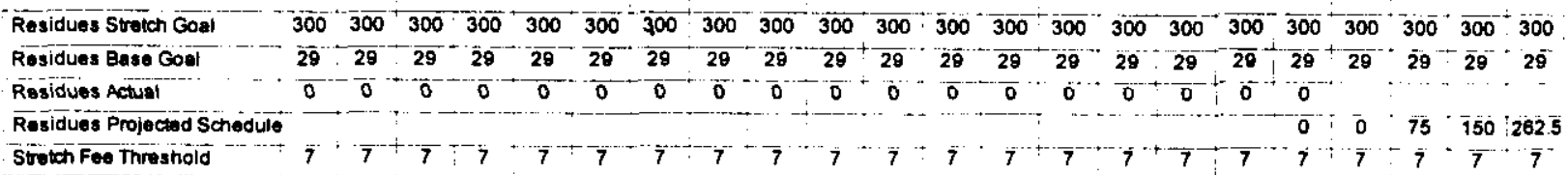

Update baseline schedule for new cementation start-up date and adjust ash schedule for preparatory work.

\section{KEY INTECRATION ACTIVITIES}

- Working on interface agreement between PFP and Waste Management to define requirements and responsibilities to support Central Waste Complex (CWC) and WIPP acceptance of packaged residues.

- $\quad$ Continue work with Rocky Flats to procure containers (Pipe-n-Go) to support PFP Residue Stabilization without the need for another procurement action. Work continues with Rocky Flats to reach a joint resolution to PFP stabilization heating process.

- Joint PNNL/Plutonium Process Support Laboratories (PPSL) $\mathrm{Mg}(\mathrm{OH})_{2}$ continues:

- $\quad$ Status meeting with PNNL, PFP and DOE RL.

- $\quad$ PPSL preparing to conduct scale testing with test set up developed by PNNL.

- Downloaded solutions (1 product receiver (PR) container) in room 227 to support Phase II testing by PPSL. 


\section{Nuclear Materials Stabilized during the CurRent Period}

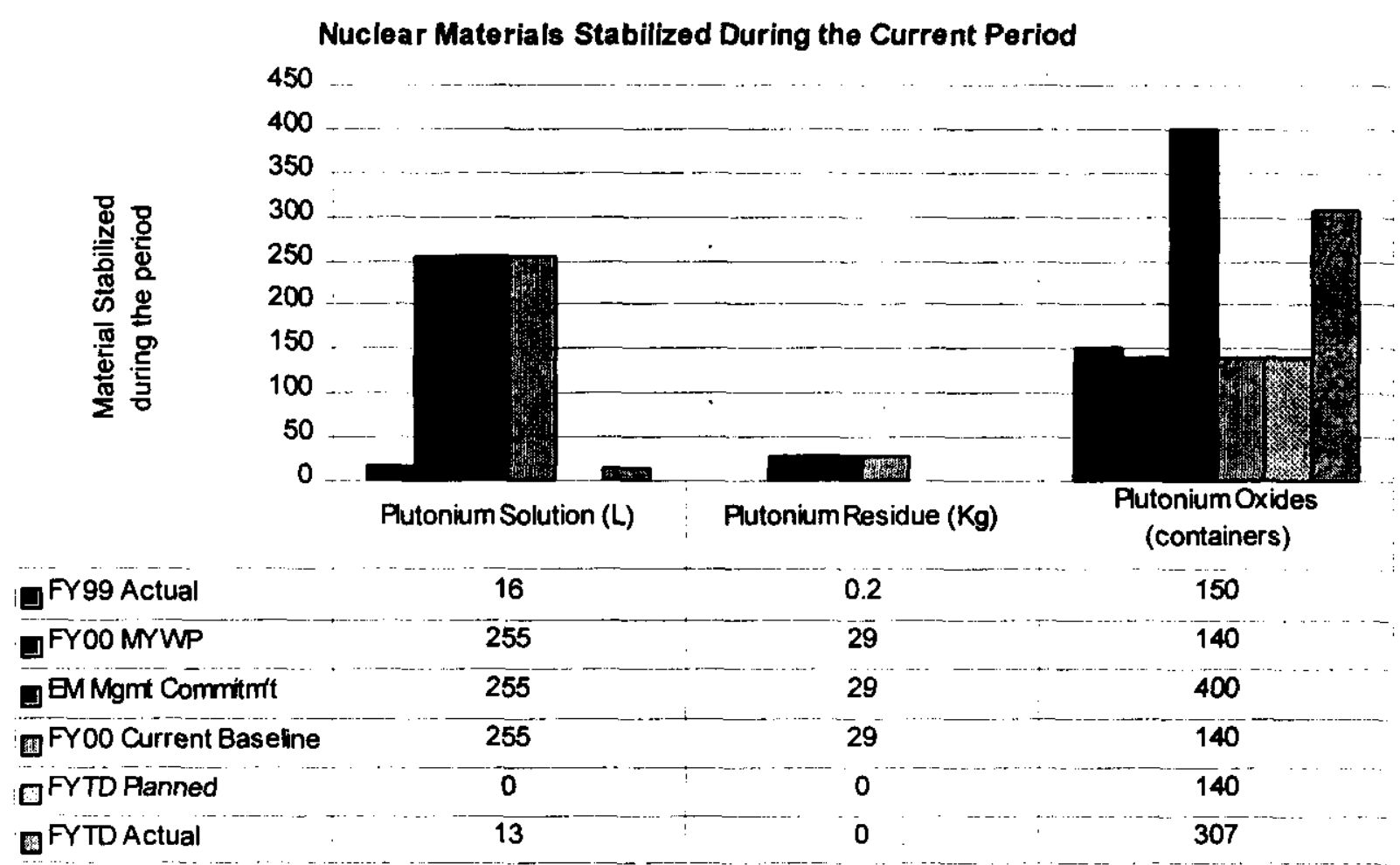

Plutonium Solution: Laboratory testing resulted in early stabilization of 13 liters of Plutonium solution during first quarter FY00. As planned no additional stabilization of plutonium solutions were made during the second and third quarters.

Plutonium Residue: Metal/oxide stabilization was extended thru the third quarter, whereupon the focus will now be switched towards the stabilization of the solutions and residues. It is currently expected that planned quantities of stabilization of residue, solution and metal oxide will be met or exceeded for FY2000.

Plutonium Oxides: 307 cans of metal/oxides have been stabilized to date exceeding the planned quantity of 140. Approval of EIS via supplement analysis increasing charge size of furnaces by a factor of four and increasing the number of furnaces from two to five has allowed the actual stabilization to proceed faster than planned. Metal/oxide stabilization was extended through the third quarter, whereupon the focus will now be switched towards the stabilization of the solutions. 


\section{BUILDING DEACTIVATION}

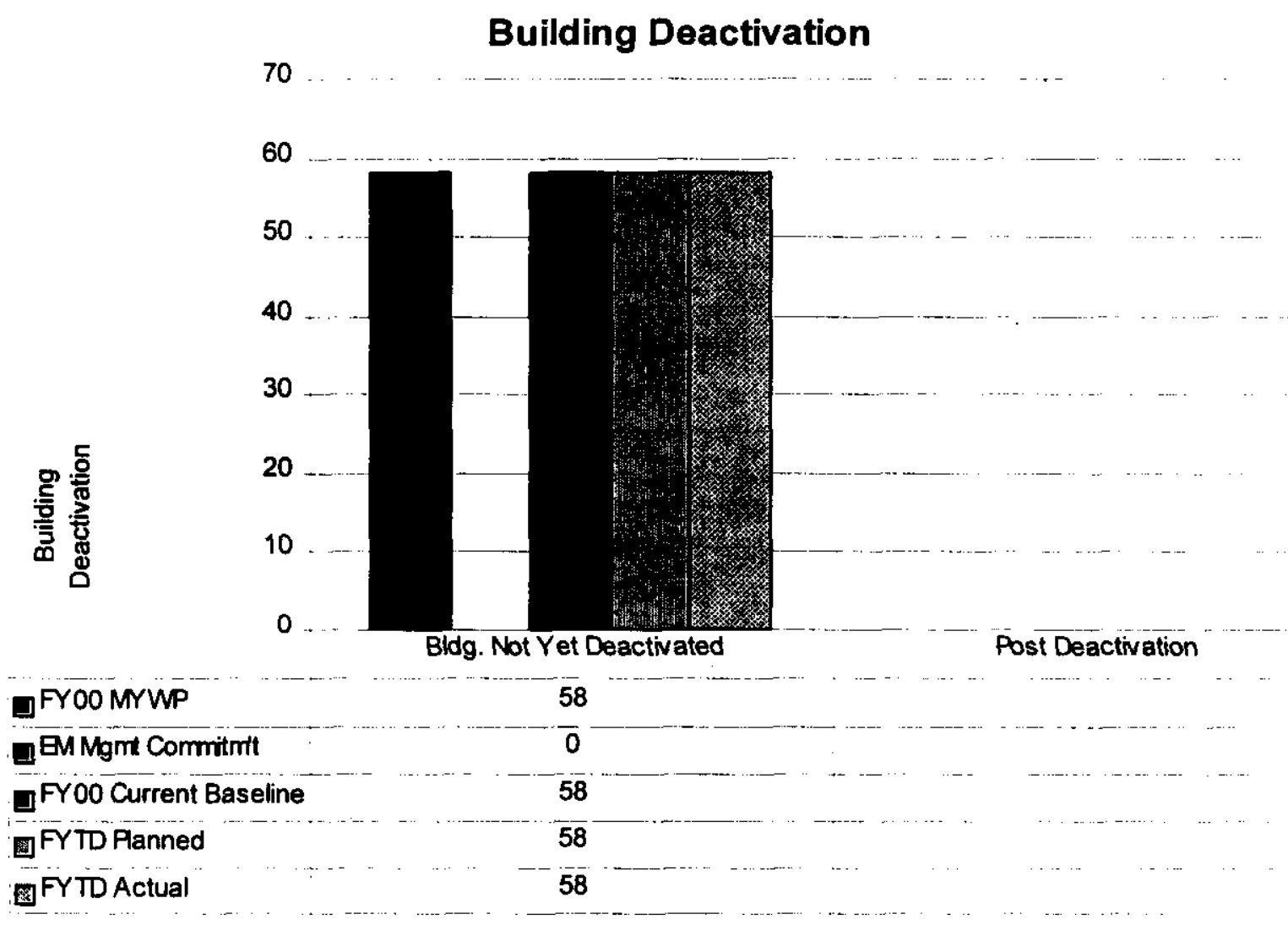

Buildings Not Yet Deactivated: Deactivation of buildings will not begin until FY2009 as documented in the Integrated Project Management Plan for the River Corridor

Post Deactivation: There are no buildings in post deactivation. 


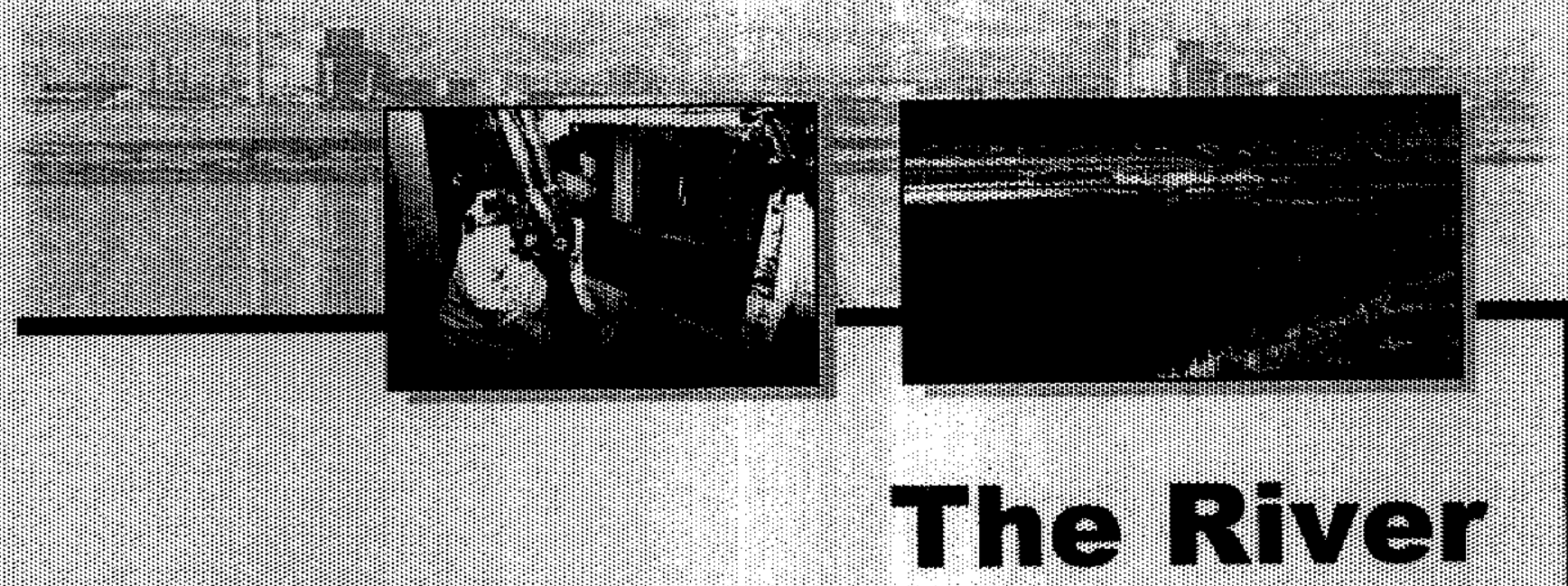

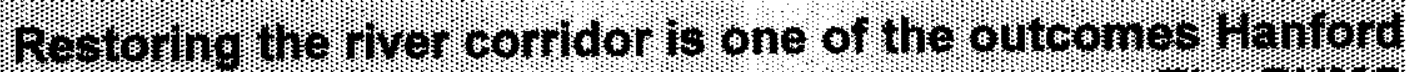

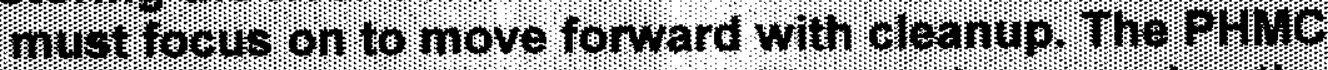

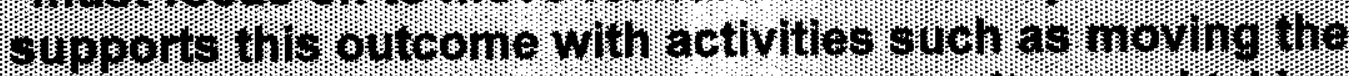

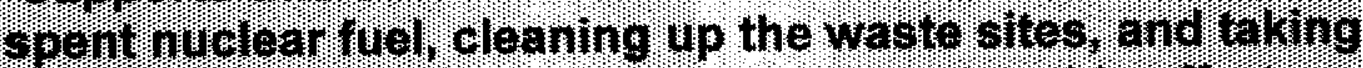

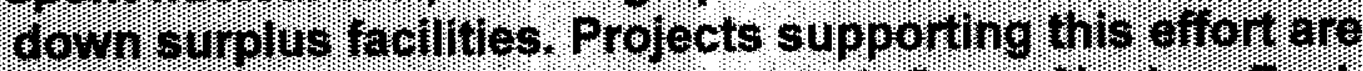

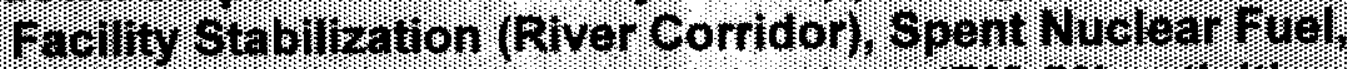

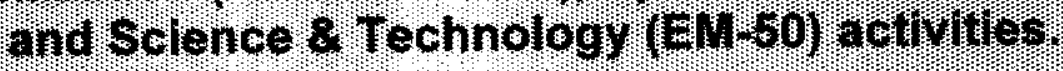




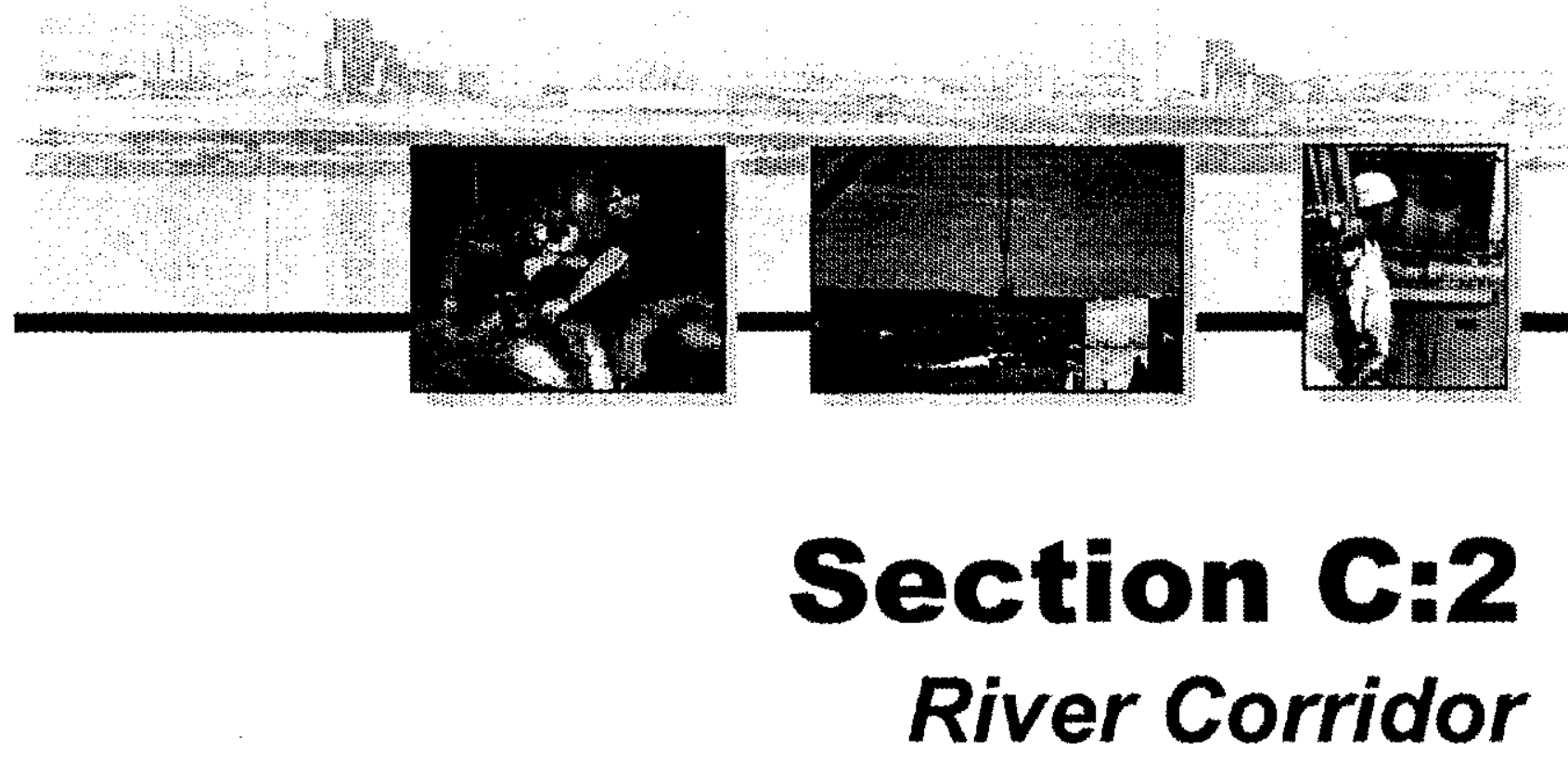

PROJECT MANAGERS

P.M. Knollmeyer, RL

(509) 376-7435

N. Boyter, FH

(509) $373-3725$ 


\section{SUMMARY}

The River Corridor Project consists of the following projects: 300 Area Liquid Effluent Facility (LEF) WBS 1.2.3.2, Project Baseline Summary (PBS) WM05; B-Plant, WBS 1.4.1, PBS TP01; 300 Area/Special Nuclear Materials, WBS 1.4.4, PBS TP04; Transition Project Management, WBS 1.4.6, PBS TP12; Accelerated Deactivation, WBS 1.4.8, PBS TP10; 324/327 Facility Transition, WBS 1.4.10, PBS TP08; and Hanford Surplus Facility Program (300 Area Revitalization), WBS 1.4.11, PBS TP14.

PBS WM05 is divided between WBS 1.2.3.1, Liquid Effluents (200 LEF) and WBS 1.2.3.2, 310 TEDF/340 Facility (300 LEF). The $310 \mathrm{TEDF} / 340$ Facility work scope is now included in the River Corridor Project, whereas the Liquid Effluents (200 LEF) work scope has remained in Waste Management. For the purpose of performance analysis, PBS WM05 is reported in its entirety in the Waste Management Project, which has the majority of the work scope and funding incorporated in their baseline.

NOTE: Unless otherwise noted, the Safety, Conduct of Operations, Milestone Achievement, Metrics and Cost/Schedule data contained herein is as of June 30,2000. All other information is as of July 27,2000 .

The River Corridor Project and other Fluor Hanford projects successfully completed the Integrated Safety Management System Phase II Verification following a multi-facility review led by the U.S. Department of Energy (DOE), Richland Operations Office (RL). The Phase II Verification is the final step in establishing and implementing a safety management system that meets established contractual requirements based in 48 CFR 970. After completion of initial verification, organizational efforts will be directed at maintaining the system so that work is performed safely, and the criteria for maintaining and sustaining the management system are met.

Good progress was made toward closeout of the actions required by the B Plant transfer Memorandum of Agreement (MOA). The closeout activities for the B Plant transfer to the Environmental Restoration Contract (Bechtel Hanford, Inc.) were completed 10 days ahead of the Washington State Department of Health (WDOH) due date of July 28, 2000.

Progress continues toward Accelerated Deactivation of the 327 Facility with an additional 23 specimen containers transferred to the 327 A Cell (packaging cell) for a total of 225 of the planned 294 containers. Also, four concrete lined drums containing 19 waste buckets were shipped to the Central Waste Complex (CWC), and $3.6 \mathrm{~m}^{3}$ of bulk waste were packaged.

An additional 20 backlog Low Level Waste drums have been shipped from the 324 Building for a total of 70 out of 88 . In-cell work is under way to pick up and package loose granular mixed waste from the B Cell floor. This is a major requirement in satisfying Tri-Party Agreement Milestone M-89-02.

All 17 grout containers scheduled for shipment this fiscal year have now been shipped to the Low-level Burial Grounds in the 200 Area. Shipment of this waste is critical to meeting TPA 
milestone M-89-02, "Complete Removal of 324 Building Radiochemical Engineering Cell (REC) B Cell Mixed Waste (MW) and Equipment," due November 2000.

On June 30, 2000, the 300 Area Accelerated Closure Project Plan was submitted to RL. The submittal completes the deliverable for Performance Incentive FH-RC-5SS (PBS TP-14) to develop an innovative and integrated plan, schedule, and cost estimate for the accelerated closure of a significant portion of the 300 Area.

The Accelerated Deactivation project is making good progress in planning for the disposition of approximately 1,865 metric tons (MT) of Hanford Unirradiated Uranium. The Environmental Assessment Approval for Uranium Disposition was obtained. This was a critical path item, essential for any of the Uranium disposition paths. The first shipment of T-Hoppers to Portsmouth began July 27, 2000. Some of the steps taken in preparation were:

- $\quad$ Painting the $78 \mathrm{~T}$-Hoppers to correct a problem with contaminated peeling paint.

- The Shipper/Receiver plan for the transfer of materials to Portsmouth, Ohio, was approved by the U.S. Department of Energy, Richland Operations Office (RL) and U.S. Department of Energy, Oak Ridge Operations (ORO) management.

Fiscal-year-to-date milestone performance (EA, DOE-HQ, and RL) shows that four of five milestones (80 percent) were completed on or ahead of schedule and one milestone is overdue. The Milestone Achievement details, found following cost and schedule variance analysis, provide further information on all milestone types.

\section{ACCOMPLISHMENTS}

The River Corridor Project and other Fluor Hanford projects successfully completed the Integrated Safety Management System Phase II Verification following a multi-facility review led by the U.S. Department of Energy (DOE), Richland Operations Office (RL).

An additional 20 backlog Low Level Waste drums have been shipped from the 324 Building for a total of 70 out of 88 . Also, in-cell work is under way to pick up and package loose granular mixed waste from the B Cell floor. This is a major requirement in satisfying Tri-Party Agreement Milestone M-89-02.

All 17 grout containers scheduled for shipment from the 324 Building this fiscal year have now been shipped.

In support of the sulfuric acid unloading effort at the 310 Treated Effluent Disposal Facility (TEDF, a contingency waste analysis plan was established which would allow for "Treatment by Generator" activities in the event that spills or equipment washing resulted in corrosive wastes being collected in the 310 TEDF sump. The plan was not needed but will be maintained for future use.

Washington State Department of Health (WDOH) provided verbal approval for the 300 Area Process Sewer Notice of Construction on July 12, 2000, with written approval to follow. Environmental Protection Agency approval is pending. 
An additional 23 specimen containers from the 327 Building Dry Storage were transferred to the 327 A Cell (packaging cell) for a total of 225 of the planned 294 containers. Also, four concrete lined drums containing 19 waste buckets were shipped to the Central Waste Complex (CWC), and $3.6 \mathrm{~m}^{3}$ of bulk waste were packaged.

On June 30, 2000, the 300 Area Accelerated Closure Project Plan was submitted to RL. The submittal completes the deliverable for Performance Incentive FH-RC-5SS (PBS TP-14) to develop an innovative and integrated plan, schedule, and cost estimate for the accelerated closure of a significant portion of the 300 Area.

Environmental Assessment Approval for Uranium Disposition was obtained. This was a critical path item, essential for any of the Uranium disposition paths. Seventy-eight T-Hoppers were painted which corrected a problem with contaminated peeling paint. The Shipper/Receiver plan for the transfer of materials to Portsmouth, Ohio, has been approved by the U.S. Department of Energy, Richland Operations Office (RL) and U.S. Department of Energy, Oak Ridge Operations (ORO) management. The first shipment of T-Hoppers to Portsmouth began July 27, 2000.

A biological clean-up procedure for 200 Area Accelerated Deactivation Project facility support was approved and released. The procedure was cited as a major strength by ISMS assessors, and a positive observation per a DOE- RL surveillance.

The closeout activities for the B Plant transfer to Environmental Restoration Contract (Bechtel Hanford, Inc.) were completed 10 days ahead of the Washington State Department of Health WDOH due date of July 28, 2000.

\section{SAFETY}

Significant decreases in Occupational Safety and Health Act (OSHA) recordable case rate and in DOE Safety Cost Index have recently occurred. The project has exceeded 750,000 hours without an OSHA recordable. The project has an overall green rating - stable at excellent rates. 


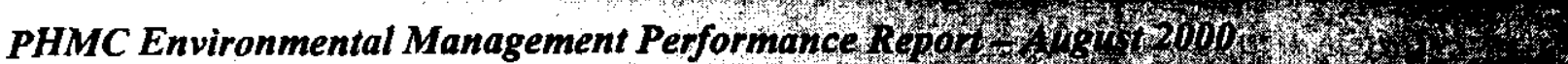

Section C: 2 - River Corridor

12

Lost Away Workday Case Rate

Cases per 200,000 hours

10

8

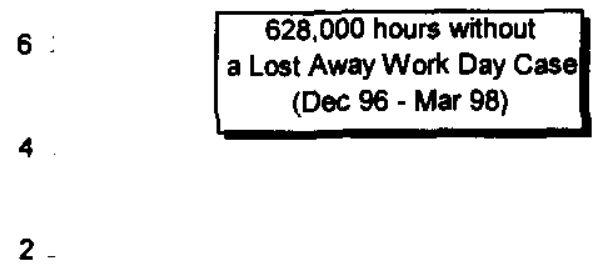

4

2

0

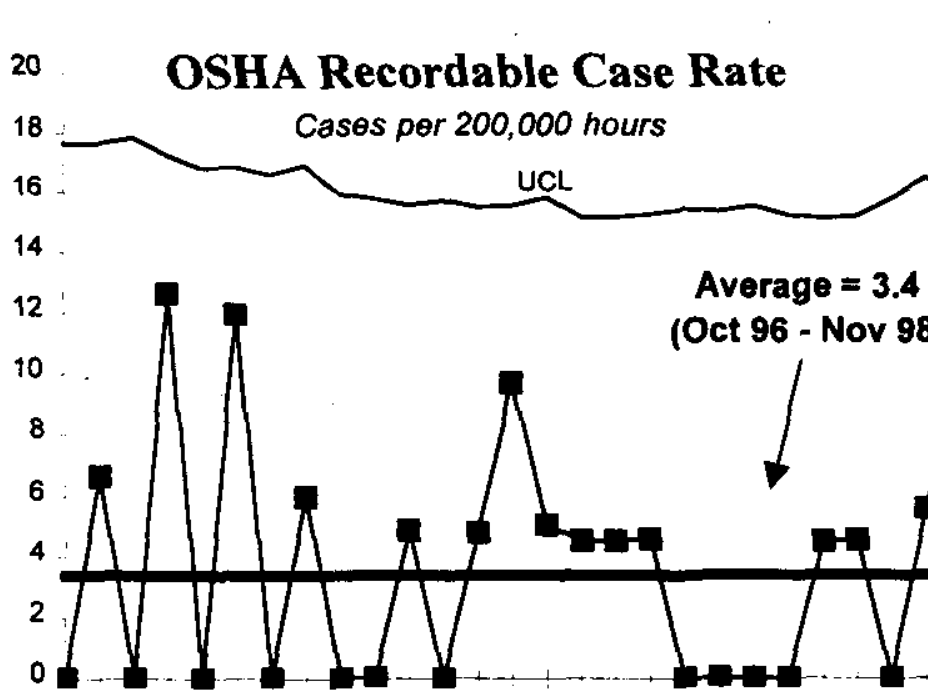

628,000 hours without a Lost Away Work Day Case (Dec 96 - Mar 98)

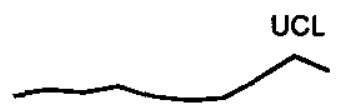

Average $=1.4$

(Mar 98 - Dec 98)

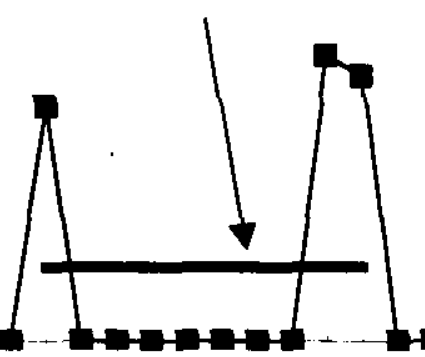

Green

Project Safe Hours $=\mathbf{9 4 4 , 4 0 0}$ FY $1999=0.7$ FY 2000 to date $=0.0$ 


\section{CONDUCT OF OPERATIONS / ISMS STATUS CONDUCT OF OPERATIONS \\ EVENTS PER 200,000 HOURS}

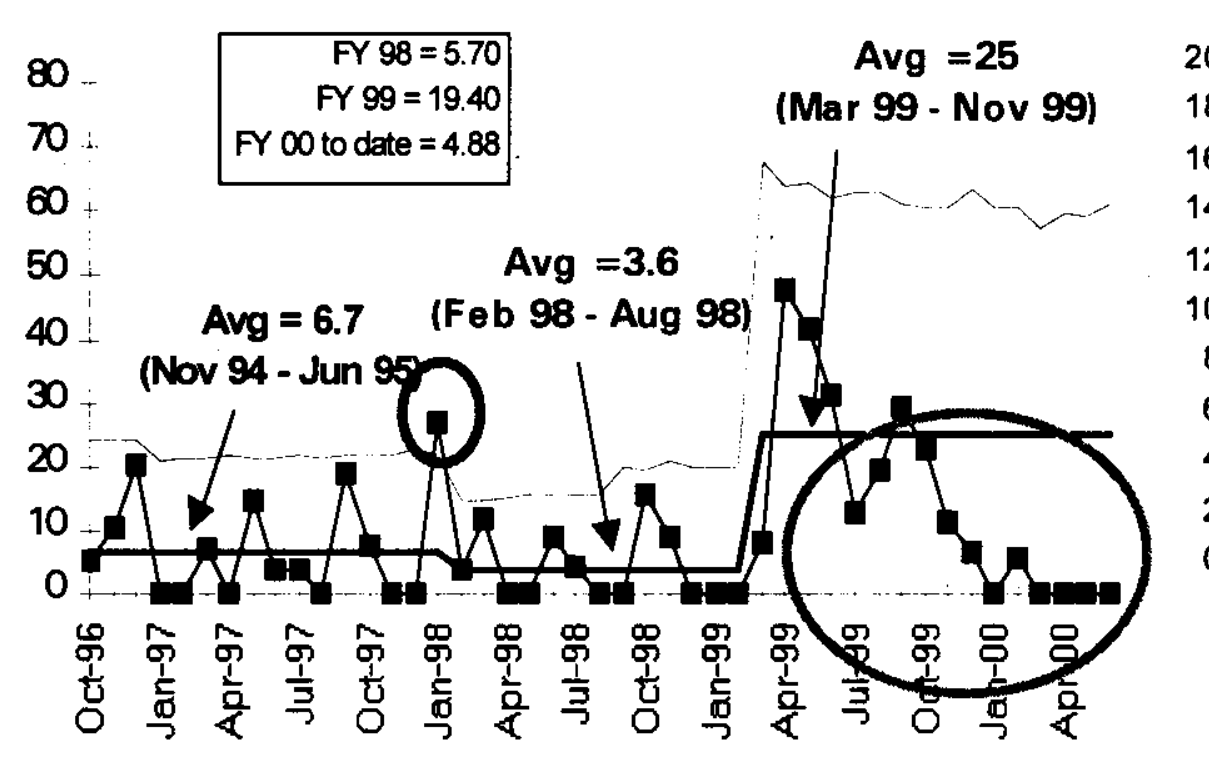

No. of Reports

Past 12 Months

\section{ISMS STATUS}

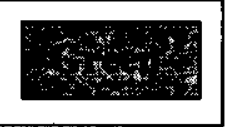

- $\quad$ ISMS Internal Readiness Review (IRR) completed; closure plan in progress

- $\quad$ Phase I Verification successfully completed April 28, 2000

- Declared Readiness for ISMS Phase II Verification May 2, 2000

- ISMS Phase II Verification successfully completed July 13,2000

\section{BREAKTHROUGHS / OPPORTUNITIES FOR IMPROVEMENT}

\section{Breakthroughs}

- $\quad$ Savings Through Alternative Disposition Strategy - Final disposition of Unirridiated Uranium fuel elements to low-level waste burial grounds vs. packaging and transportation to Portsmouth, Ohio for interim storage will save in excess of $\$ 1 \mathrm{M}$.

- 300 Area Accelerated Closure Plan - Based on the preparation of the 300 Area Accelerated Closure Plan an opportunity to accelerate closure of a significant portion of the 300 Area nearly four decades ahead of the current deactivation plan for an estimated savings of over $\$ 1.0 \mathrm{~B}$.

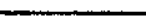




\section{Opportunities for Improvement}

- 324 Project Planning/Execution - An emphasis on improved schedule management to ensure that critical path negative float is recovered to positive float continues. Critical path method analysis of baseline

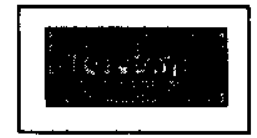
schedule has lead to several schedule sequence changes devised to improve baseline performance. As work progresses, the need to re-sequence will continue to be assessed.

- 327 Building Conduct of Operations - Deactivation project work activities were temporarily curtailed by the facility management to focus efforts on procedure upgrades and Conduct of Operation concerns.

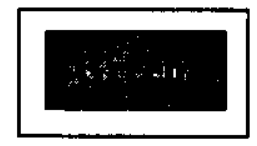
After a five-week effort, the deactivation work was reinstituted utilizing new procedures. Senior management oversight has been implemented to review the daily work plans and oversee work evolutions in the facility.

\section{UPCOMING ACTIVITIES}

- 300 Area Waste Acid Treatment System (WATS) Resource Conservation and Recovery Act (RCRA) Closure Activities - The final report due to RL has been delayed until September 2000 due to the review and comment cycle with Washington Department of Ecology (WDOE). A baseline change request has been submitted to delete the milestone, TRP-99-301, "Submit Final Report on WATS Closure Activities to $R L$."

- $\quad$ TPA Milestone M-89-02 - Complete Removal of 324 Building Radiochemical Engineering Cell (REC) B Cell Mixed Waste (MW) and Equipment by November 2000.

\section{Cost Performance (\$M):}

\begin{tabular}{|l|c|c|c|}
\hline & BCWP & ACWP & VARIANCE \\
\hline River Corridor Project & $\$ 45.2$ & $\$ 40.6$ & $\$ 4.7$ \\
\hline
\end{tabular}

The $\$ 4.7$ million (10.0 percent) favorable cost variance is primarily due to performing 327 accelerated deactivation work scope and the Fluor Project Management Team re-structuring. Further information at the PBS level can be found in the following Cost Variance Analysis details. 
Schedule Performance (\$M):

\begin{tabular}{|l|c|c|c|}
\hline & BCWP & BCWS & VARIANCE \\
\hline River Corridor Project & $\$ 45.2$ & $\$ 44.4$ & $\$ .9$ \\
\hline
\end{tabular}

The $\$ 0.9$ million ( 2.0 percent) favorable schedule variance is within the established threshold. Further information at the PBS level can be found in the following Schedule Variance Analysis details.

\section{FY 2000 Cost/Schedule Performance - All Fund Types Cumulative to Date STATUS - (\$000)}

\begin{tabular}{|c|c|c|c|c|c|c|c|c|c|c|c|c|c|c|c|c|c|}
\hline & & & & & & & FYTD & & & & & & & & & & \\
\hline & By PBS & & CWS & & CWP & & CWP & & SV & $\%$ & & $\mathrm{CV}$ & $\%$ & & PEM & & EAC \\
\hline $\begin{array}{l}\text { PBS TP01 } \\
\text { WBS } 1.4 .1\end{array}$ & B-Pfant & $\$$ & 460 & S & 455 & $\$$ & 522 & \$ & (5) & $0 \%$ & $\$$ & (67) & $0 \%$ & $\$$ & 460 & $\mathbf{S}$ & 575 \\
\hline $\begin{array}{l}\text { PBS TP04 } \\
\text { WBS } 1.4 .4\end{array}$ & $\begin{array}{l}300 \text { Area/ Special Nuclear } \\
\text { Materials }\end{array}$ & s & 1,953 & $\$$ & 1,944 & $\$$ & 1,919 & S & (9) & $0 \%$ & $\mathbf{s}$ & 26 & $1 \%$ & $\mathbf{S}$ & 2,654 & $\$$ & 2,994 \\
\hline $\begin{array}{l}\text { PBS TP12 } \\
\text { WBS } 1.4 .6\end{array}$ & $\begin{array}{l}\text { Transition Program } \\
\text { Management }\end{array}$ & $\mathbf{s}$ & 12,499 & $\mathbf{s}$ & 12,446 & $\$$ & 10,443 & \$ & $(52)$ & $0 \%$ & $\$$ & 2,003 & $16 \%$ & $\mathbf{S}$ & 16,792 & $\$$ & 13,617 \\
\hline $\begin{array}{l}\text { PBS TP10 } \\
\text { WBS } 1.4 .8\end{array}$ & Accelerated Deactivation & $\mathbf{s}$ & 1,556 & $\$$ & 1,556 & $\$$ & 1,529 & $\$$ & $(0)$ & $0 \%$ & s & 27 & $2 \%$ & $\$$ & 2,107 & $\mathbf{S}$ & 3,388 \\
\hline $\begin{array}{l}\text { PBS TP08 } \\
\text { WBS } 1.4 .10\end{array}$ & 324/327 Facility Transition & s & 25,365 & $\$$ & 26,269 & $\$$ & 24,129 & $\$$ & 904 & $4 \%$ & $\$$ & 2,140 & $8 \%$ & S & 35,304 & $\$$ & 35,417 \\
\hline $\begin{array}{l}\text { PBS TP14 } \\
\text { WBS } 1.4 .11\end{array}$ & $\begin{array}{l}\text { Hanford Surplus Facility } \\
\text { Program (300Area } \\
\text { Revitalization) }\end{array}$ & $\$$ & 2,530 & S & 2,574 & $\$$ & 2,042 & S & 44 & $2 \%$ & $\$$ & 532 & $21 \%$ & $\mathbf{S}$ & 2,874 & $\$$ & 2,954 \\
\hline & Total & $\$$ & 44,364 & $\$$ & 45,245 & s & 40,584 & $\$$ & 881 & $2 \%$ & 5 & 4,661 & $10 \%$ & $\$$ & 60,191 & $\$$ & 58,945 \\
\hline
\end{tabular}

Notes: RL-Directed costs (steam and laundry) are included in the PEM BCWS. Transition Project Management includes NMS portion of TP12. 310 TEDF/340 Facility performance data is reported under PBS WMO5 (Waste Management) 


\section{Cost/SChedule Performance Indices (MONTHLY AND FYTD)}

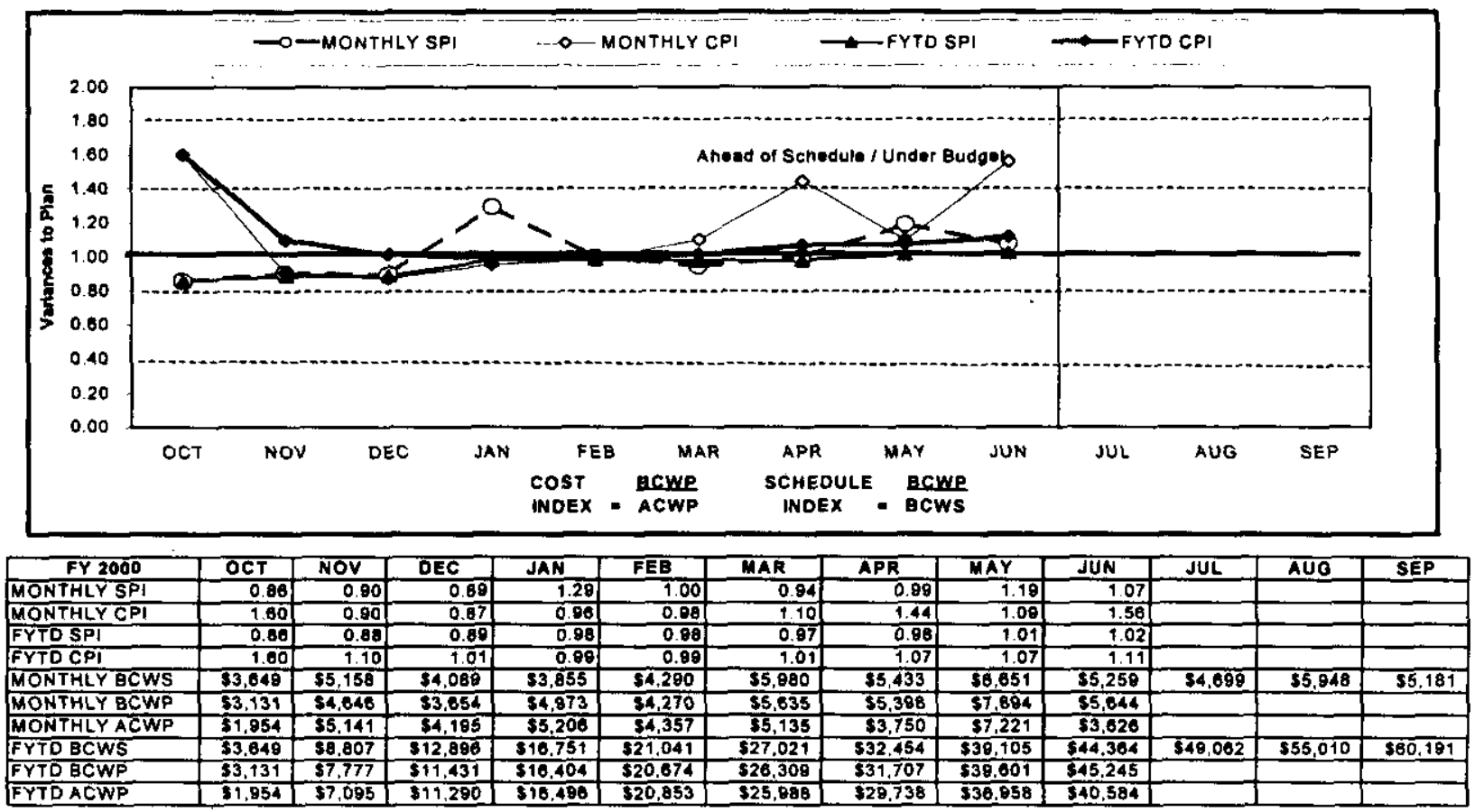

\section{COSt VARIANCE ANALYSIS: $(+\$ 4.7 M)$}

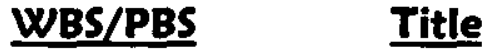

\subsubsection{0/TP08 324/327 Facility Transition}

Description and Cause: The favorable cost variance is primarily due to performing 327 facility accelerated deactivation work scope.

Impact: Out year work scope is completed ahead of schedule.

Corrective Action: None.

\subsection{6/TP12 Transition Project Management}

Description and Cause: The favorable cost variance is primarily due to the Fluor Project Management Team re-structuring which has mapped personnel from the sub-project to other subprojects (i.e. Nuclear Material Stabilization), resulting in underruns in labor and contractor support.

Impact: No impact.

Corrective Action: Although this PBS reflects a substantial cost variance, the funding is less than the scope. 


\subsubsection{1/TP14 HSFP 300 Area Revitalization}

Description and Cause: The favorable cost variance is primarily due to lower than planned costs in associated with Accelerated Closure Plan activities.

Impact: No impact.

Corrective Action: Any underruns in funding will be utilized to support super stretch activities and emerging work scope.

All other PBS variances are within established thresholds.

\section{SCHEDULE VARIANCE ANALYSIS: $(\$ 0.9 \mathrm{M})$}

All PBS variances are within established thresholds.

\section{FUNDS MANAGEMENT FUNDS VS SPENDINC FORECAST $(\$ 000)$ FY TO DATE THROUGH JUNE 2000 (FLUOR HANFORD, INC. ONLY)}

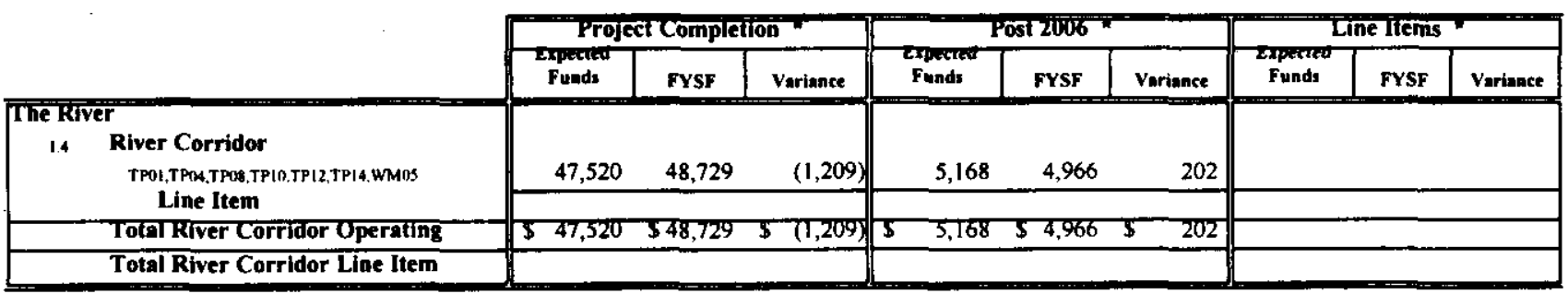

* Control Point

\section{ISSUES}

\section{Technical Issues}

Issue: B Plant Filter Changeout - Overdue calibration of equipment on the B Plant exhaust system has delayed the aerosol challenge test for ACT 1 and restart of the exhaust stack.

Impact: Operation of exhaust system delayed until repairs are completed. Continues to accrue costs for required surveillances while system is non-operational. Final costs are exceeding revised baseline of $\$ 350 \mathrm{~K}$. Additionally, this may cause delay in meeting the July 27, 2000 date for restart of the ventilation system as agreed to with Washington State Department of Health (WDOH).

Corrective Action: WDOH approved extension of stack outage to July 28, 2000. Restart can be successfully achieved provided Bechtel Hanford, Inc. completes required calibrations.

\section{DOE/Regulator/External Issues}

Issue: While the current schedule for completing M-89-02, "Complete Removal of 324 Building Radiochemical Engineering Cells (REC) B Cell Mixed Waste (MW) and Equipment," is 
targeting completion on schedule, there is not schedule contingency for equipment failure.

Impacts: Timely completion of the milestone could be placed in jeopardy if an equipment failure were to occur.

Corrective Action: A decision must be made in the near future whether to request an extension to the milestone as provided for in the Tri-Party Agreement under Article XL, Good Cause for Extensions. A review of the option has been completed by the contractor and recommendation transmitted to $\mathrm{RL}$.

Issue: Approval by DOE-HQ of the Unirradiated Uranium (UU) billet Safety Analysis Report for Packaging (SARP), Revision K, is required by August 15, 2000 if any shipment is to be made during FY 2000 as requested by the customer.

Impacts: Failure to gain approval on or before August 15, 2000, may jeopardize the shipment schedule for the billets, thus losing the opportunity to complete the Tri-Party Agreement milestone (MX-92-06-T1) for billet transfer by December 31, 2000. Corrective Action: $\mathrm{RL}$ is aware of the issue. Revisions $\mathrm{K}$ and $\mathrm{L}$ of the billet SARP are being reviewed by DOE-HQ, and a Certificate of Compliance is expected by the end of August 2000.

\section{Baseline Change Requests Currently in Process (\$000)}

\begin{tabular}{|c|c|c|c|c|c|c|c|c|c|}
\hline $\begin{array}{l}\text { PROJECT } \\
\text { CHANGE } \\
\text { NUMBER }\end{array}$ & $\begin{array}{l}\text { DATE } \\
\text { ORIGIN. }\end{array}$ & BCR TITLE & $\begin{array}{c}\text { FYOO } \\
\text { COST } \\
\text { IMPACT }\end{array}$ & $\mathrm{SCH}$ & $\mathrm{TECH}$ & $\begin{array}{c}\text { DATE } \\
\text { To } \\
\text { FH CCB }\end{array}$ & $\begin{array}{c}\text { FH } \\
\text { CCB } \\
\text { APR'VD }\end{array}$ & $\begin{array}{c}\text { RL } \\
\text { APRVD }\end{array}$ & $\begin{array}{l}\text { CURRENT } \\
\text { STATUS }\end{array}$ \\
\hline FSP-00-002 & $\$ 1 / 2 / 9 \theta$ & Mark-42 Project Completion & so & & $x$ & $0405 / 00$ & & & $\begin{array}{l}\text { Additional funding } \\
\text { requested }\end{array}$ \\
\hline FSP-00-046 & $5 / 24 / 00$ & Remove FEB Activities from FY2000 & $-\$ 277$ & & $x$ & $08 / 18 / 00$ & $06 / 21100$ & NA & \\
\hline FSP-00-047 & $5 / 2400$ & Rebasline PES * *RL-TP10 "Accelerated Deactivetion" & so & $x$ & $x$ & $06 / 2200$ & & & $\begin{array}{l}\text { With RL for } \\
\text { approval }\end{array}$ \\
\hline FSP-00-048 & 615100 & RLMQ Moratorium on Transfer of Faclitities & so & $x$ & & $06 / 18 / 00$ & & & $\begin{array}{l}\text { Awaiting letter of } \\
\text { direction }\end{array}$ \\
\hline FSP-00-052 & $6 / 13 / 00$ & Uranium Dispostion Project & $\$ 195$ & & $x$ & $07 / 0800$ & $07 / 12 / 00$ & NA & \\
\hline FSP-00-054 & $6 / 26100$ & FHA ImplementationPPNNL Legecy Waste & $\$ \$$ & $x$ & $x$ & 0710800 & Disapprvo & NA & DISAPPROVED \\
\hline FSP-00-055 & $6 / 27 / 00$ & Implement 10 CFR 835.101, Rad protection Program & $\$ 76$ & & $x$ & NA & NA & NA & $\begin{array}{l}\text { Aoproved at Project } \\
\text { Level }\end{array}$ \\
\hline FSP-00-056 & $6 / 27 / 00$ & Six Ton Crane Waste & $-\$ 34$ & & $x$ & NA & NA & NA & $\begin{array}{l}\text { Approved at Project } \\
\text { Level }\end{array}$ \\
\hline FSP-00-057 & 62800 & Ion Exchenge Column Removal &.$\$ 34$ & & $x$ & $07 / 12100$ & NA & NA & $\begin{array}{l}\text { Approved at Project } \\
\text { Lovel }\end{array}$ \\
\hline FSP-D0-05B & $6 / 28100$ & Defer Robotics Activities & $-\$ 110$ & $x$ & $x$ & $07 / 1200$ & & NA & $\begin{array}{l}\text { Pending FH Change } \\
\text { Board }\end{array}$ \\
\hline FSP-00-059 & $6 / 29 / 00$ & Increase in TRU Grout Containers & $\$ 322$ & & $x$ & & & NA & In Development \\
\hline FSP-00-060 & $7 / 5100$ & Additional Suppont to NFDI & $\$ 50$ & & $x$ & NA & NA & NA & $\begin{array}{l}\text { Approved at Project } \\
\text { Level }\end{array}$ \\
\hline \multicolumn{10}{|c|}{ ADVANCE WORK AUTHOREZATIONS } \\
\hline AWA & $6 / 100$ & Urenium Dispestion Project activities & $\$ 285$ & & $x$ & $6 / 5100$ & $0 / 5 / 00$ & 00807100 & FSP-2000-052 \\
\hline AWA & $7 / 10 / 00$ & Characterization of 224T Facility & $\$ 180$ & & $x$ & $7 / 11 / 100$ & $7 / 11 / 00$ & $07 / 13 / 00$ & In development \\
\hline
\end{tabular}




\section{Milestone ACHieVeMENT}

\begin{tabular}{|c|c|c|c|c|c|c|c|c|}
\hline \multirow[b]{2}{*}{ MILESTONE TYPE } & \multicolumn{4}{|c|}{ FISCAL YEAR-TO-DATE } & \multicolumn{3}{|c|}{ REMAINING SCHEDULED } & \multirow[b]{2}{*}{$\begin{array}{l}\text { TOTAL } \\
\text { FY } 2000\end{array}$} \\
\hline & $\begin{array}{c}\text { Completed } \\
\text { Early }\end{array}$ & $\begin{array}{l}\text { Completed } \\
\text { On } \\
\text { Schedule }\end{array}$ & $\begin{array}{l}\text { Completed } \\
\text { Late }\end{array}$ & Overdue & $\begin{array}{c}\text { Forecast } \\
\text { Early }\end{array}$ & {$\left[\begin{array}{c}\text { Forecast } \\
\text { On } \\
\text { Schedule }\end{array}\right.$} & $\begin{array}{c}\text { Forecast } \\
\text { Late }\end{array}$ & \\
\hline Enforceable Agreement & 1 & 0 & 0 & 0 & 0 & 0 & 0 & \\
\hline DNFSB & 0 & 0 & 0 & 0 & 0 & 0 & 0 & 0 \\
\hline DOE-HQ & 0 & 0 & 0 & 0 & 0 & o & of & 0 \\
\hline$R \mathbf{R}$ & 2 & $T$ & 0 & 1 & 0 & 0 & of & 4 \\
\hline Total Project & 3 & $T$ & 0 & 1 & 0 & 0 & 0 & 5 \\
\hline
\end{tabular}

Green

Tri-Party Agreement / EA Milestones

M-92-13 (TRP-00-902), “ Submit 300 Area SCW Project Management Plan to Ecology

Pursuant to Agreement Action Plan Section 11.5," due 9/29/00

- $\quad$ Completed 6 months early $(3 / 28 / 00)$.

M-92-14 (TRP-02-901), "Complete Removal of Phase I 300 Area Special Case Waste and Materials," due 9/30/02

- Completed 30 months early $(03 / 28 / 00)$ pending acceptance of the plan by Ecology.

M-89-02 (TRP-99-901), "Complete Removal of 324 Building Radiochemical Engineering Cells (REC) B Cell Mixed Waste (MW) and Equipment," due 11/30/00

- Work towards completion of M-089-02 continues on schedule.

\section{DNFSB Commitments}

Nothing to report.

\section{MILESTONE EXCEPTION REPORT}

\begin{tabular}{|c|c|c|}
\hline Number/NBS Level & Milestone Title & $\begin{array}{l}\text { Baseline } \\
\text { Date }\end{array}$ \\
\hline
\end{tabular}

\section{OVerdue - 1}

TRP-99-933 RL - Containerize Dispersible Under 2A Rack 04/30/00 07/20/00

\subsubsection{0}

Cause: It has been determined it is more efficient to complete dispersible collection once size reduction of miscellaneous items is completed.

Impact: No impact.

Corrective Action: No corrective action is required. 


\section{FORECAST LATE - 0}

\section{FY 1999 OVERDUE - 1}

TRP-99-800 RL End Point Improvement Method 06/25/99 To Be

\section{4 .8}

Deleted

Cause: Resources necessary to complete this milestone were diverted to other priority work. This milestone represents an enhancement in Facility Stabilization Project's ability to plan deactivation work, but it is not essential.

Impact: No impact. This work scope is independent of the PMBS critical path and does not impact any schedule.

Corrective Action: Deletion of this milestone is included in the BCR which re-baselines TP-10 and is currently in development.

\section{Performance Objectives}

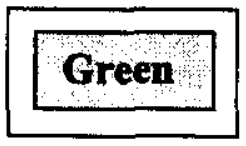

\begin{tabular}{|c|c|c|}
\hline Outcome & Performance Indicator & Status \\
\hline \multirow{5}{*}{$\begin{array}{l}\text { Restore } \\
\text { the River } \\
\text { Corridor } \\
\text { for } \\
\text { Multiple } \\
\text { Uses }\end{array}$} & $\begin{array}{l}\text { FDH-RC-2 } \\
\text { Accelerate } 324 / 327 \\
\text { Deactivation. }\end{array}$ & $\begin{array}{l}\text { On track - no issues. Current Life Cycle Schedule Variance } .61 \% \text { and } \\
\text { Life Cycle Cost Variance } .90 \text { percent. }\end{array}$ \\
\hline & $\begin{array}{l}\text { FDH-RC-2SS } \\
\text { Continue Acceleration of } \\
324 / 327 \text { Deactivation - } \\
\text { Complete } 327 \text { Facility } \\
\text { accelerated deactivation } \\
\text { activities by September } 2000 \text {. }\end{array}$ & $\begin{array}{l}\text { A change in the baseline plan for shipment of the lead-lined drums to } \\
\text { the Central Waste Complex may jeopardize the ability to ship waste in } \\
\text { a timely manner. Alternatives have been evaluated, and a contingency } \\
\text { plan has been implemented. A revised Performance Incentive (PI) has } \\
\text { been transmitted to RL modifying the PI language regarding waste } \\
\text { shipment. }\end{array}$ \\
\hline & $\begin{array}{l}\text { FDH-RC-3SS } \\
\text { Disposition Uranium Complete } \\
\text { disposition of } \sim 1865 \text { Metric } \\
\text { Tons (MT) of Hanford Uranium } \\
\text { by September } 2000 .\end{array}$ & $\begin{array}{l}\text { Unrecoverable - There are minimal constraints to accomplish this } \\
\text { work, however funding has not been identified. }\end{array}$ \\
\hline & $\begin{array}{l}\text { FDH-RC-5SS } \\
\text { Accelerate } 300 \text { Area Closure } \\
\text { Project. }\end{array}$ & Complete - Plan issued June $30,2000$. Initial feedback is positive. \\
\hline & $\begin{array}{l}\text { FDH-RC-5SS-2 } \\
\text { Accelerate Cleanup of zone } 4 \text { of } \\
300 \text { Area. }\end{array}$ & $\begin{array}{l}\text { Unrecoverable - No funds identified to support completion of physical } \\
\text { work. Engineering Evaluation/Cost Estimate is in process. }\end{array}$ \\
\hline Multiple & Comprehensive performance & All baseline work projected to be complete per PI requirements. \\
\hline
\end{tabular}




\section{KEY INTEGRATION ACTIVITIES}

- Complete National Facility Deactivation Initiative (NFDI) DOE-complex implementation plan.

- $\quad$ The RCP 324 Building B Cell project, along with Spent Nuclear Fuel (SNF), developed an alternative plan for the fuel removal activity. Agreement to use a longer inner canister for the fuel permits greater end shielding and allows manual welding and testing in the Cask Handling Area (CHA), rather than the more expensive, remote effort in B Cell. SNF and RL are reviewing the options study to determine cost savings against the 200 Area Interim Storage life cycle costs. Following the review, a memorandum of agreement will be issued documenting the interface between SNF and RCP.

- The DOE-HQ-funded study of High-Level Vault Tank 105, located in the 324 Building is being conducted by AEA Technologies to demonstrate new technology in the deactivation of high-dose radioactive tanks. The project technical plan, implementation plan, and the draft of the alternatives assessment are complete. Comments have been forwarded to AEA Technologies and have been incorporated into the assessment. The final report was issued on June 22, 2000. A mock-up demonstration of the selected technology is to be performed in August 2000.

- 300 Area Accelerated Closure Plan team consisted of Fluor Hanford, Bechtel Hanford, Inc. and Pacific Northwest National Laboratory. The planning effort was completed and submitted to RL on June 30, 2000.

- A conference call was held with AEA's UK office to discuss completion of the B Cell HVAC Duct Remediation Study that is currently funded via EM-50. As scheduled a draft of AEA's final Options Study was received by Hanford on July 19, 2000, and, following a 2-week Hanford review and comment period, will be issued in August. AEA will likely propose additional scope and EM-50 funding for FY2001 which will involve actual demonstration of the ducting access, characterization and cleanout technologies. If successful, this work may help to accelerate RCP planning for other ducting challenges in 324 and 327.

- $\quad$ An opportunity exists for receipt of PNNL facilities into TP-14. Although facility transfer is contrary to DOE-HQ guidance into EM (pipeline moratorium), PNNL does have funds for FY 2001/2002 Surveillance and Maintenance identified for transfer to FH. 


\section{BUILDING DEACTIVATION}

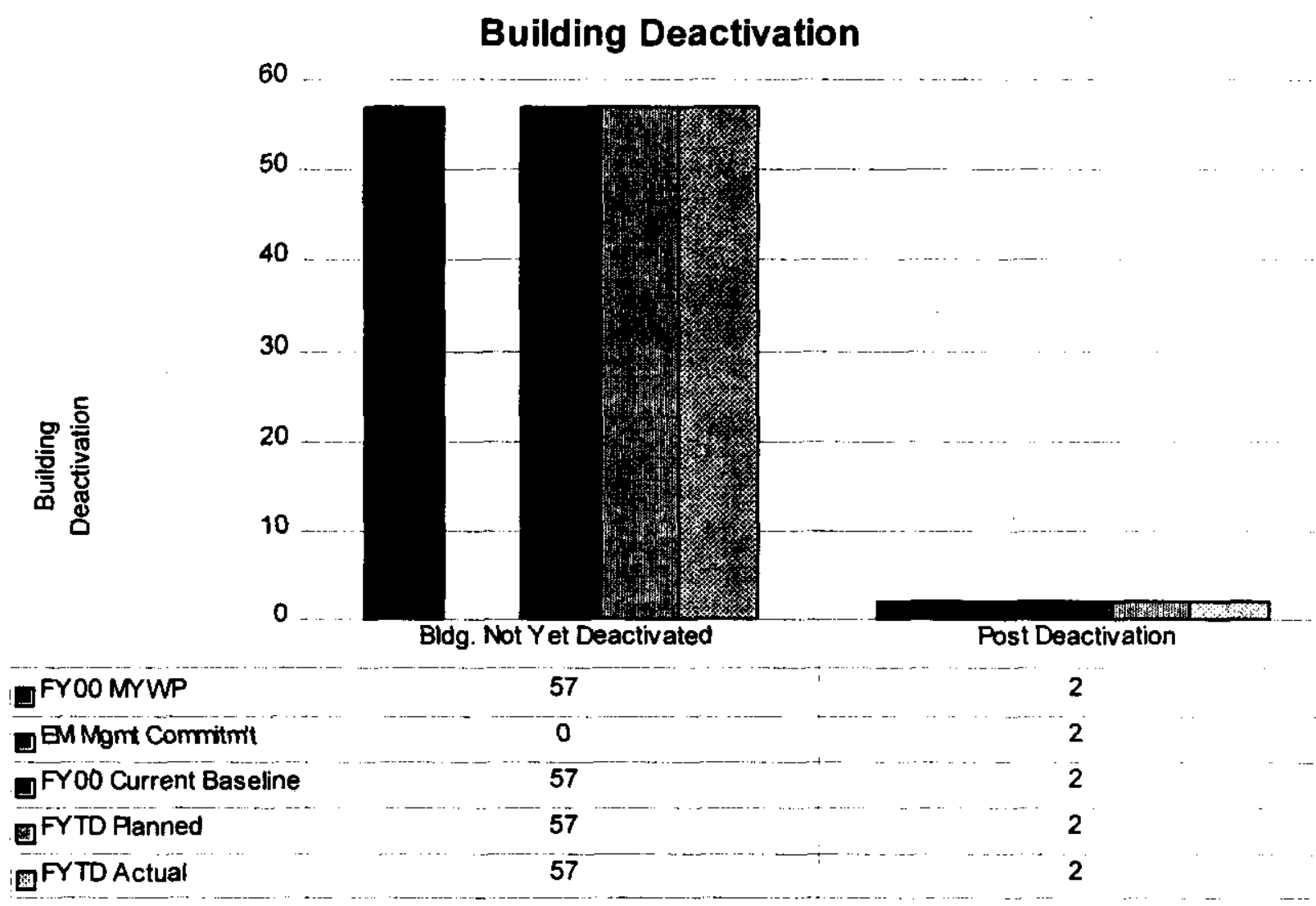

Buildings Not Yet Deactivated: Current approved budget does not fund building deactivation in the 300 area. Therefore, plans for deactivation have been deferred to FY2002.

Post Deactivation: These are two storage building to be turned over to BHI when the 324/327 Transition Project is completed in FY 2007. 


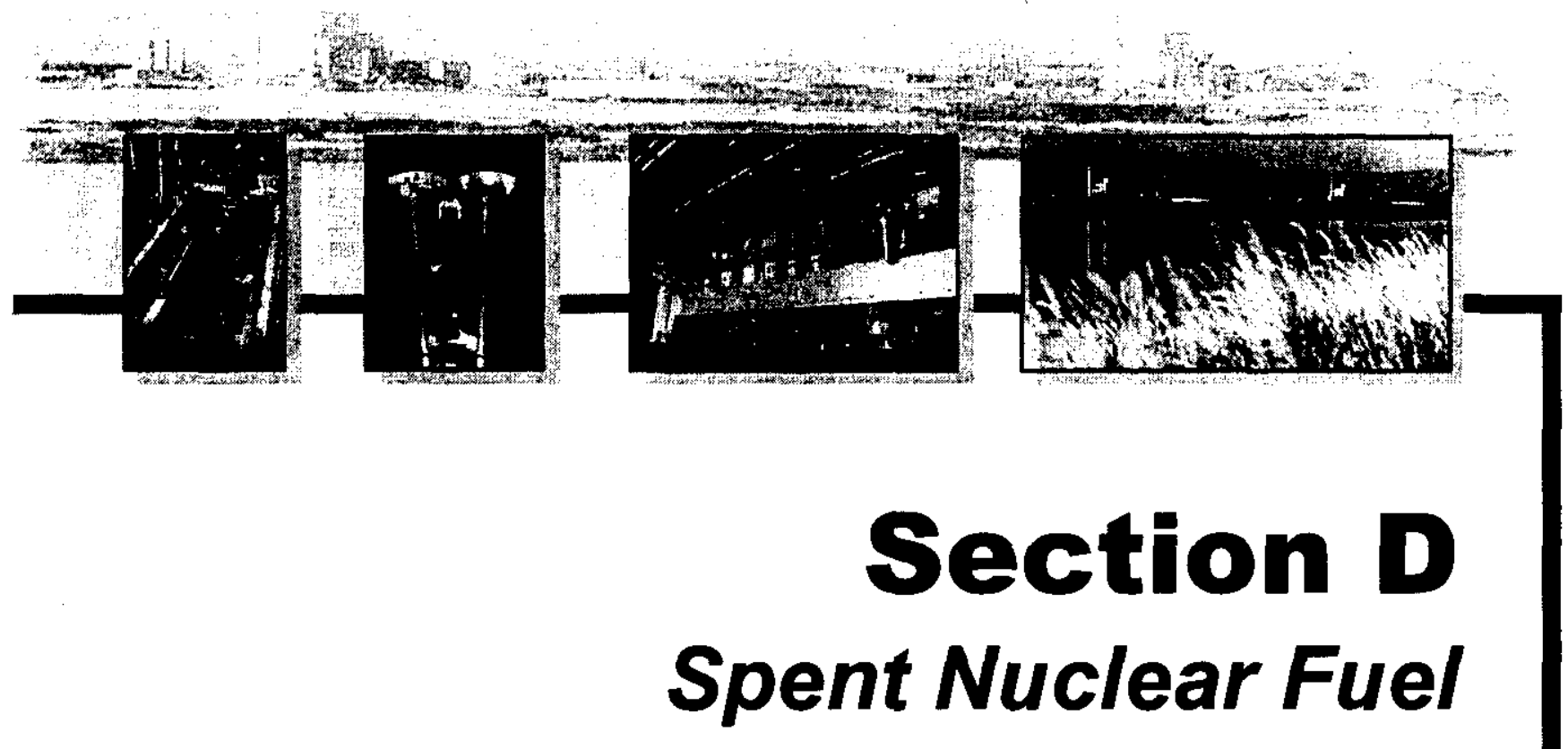

PROJECT MANAGERS

P.G. Loscoe, RL (509) 373-7465

J.H. Wicks Jr., FH (509) 373-9372 


\section{SUMMARY}

The Spent Nuclear Fuel (SNF) mission consists of the Spent Nuclear Fuel Project WBS 1.3.1.1 (Project Baseline Summary [PBS] WM01) and the subsequent Canister Storage Building (CSB) Operations Project WBS 1.3.2.1 (PBS WM02), which does not start until FY 2004.

NOTE: Unless otherwise noted, the Safety, Conduct of Operations, Milestone Achievement, and Cost/Schedule data contained herein is as of June 30,2000. All other information is as of July $24,2000$.

The third and fourth shipments of Multi-Canister Overpacks (MCOs) were received from Joseph Oat, Inc. ahead of schedule. A total of 32 MCOs have been received at the Hanford Site as of July 14,2000 . Fabrication of the MCO baskets continues at the 328 shop at the Hanford Site.

Fiscal year-to-date milestone performance (EA, DOE-HQ, and RL) shows that three out of four milestones ( 75 percent) were completed on or ahead of schedule and one milestone was completed late.

The Milestone Achievement details, found following cost and schedule variance analysis, which provides further information on all milestone types.

\section{ACCOMPLISHMENTS}

- $\quad$ Since October 2, 1999 the Project has achieved 1,375,651 safe work hours without a lost time incident.

- The third and fourth shipments of Multi-Canister Overpacks (MCOs) were received from Joseph Oat, Inc. ahead of schedule. A total of 32 MCOs have been received at the Hanford Site as of July 14, 2000. Fabrication of the MCO baskets continues at the 328 shop at the Hanford Site.

- $\quad$ The Cold Vacuum Drying (CVD) Facility Bay 5 was turned over to Operations for operational testing and training.

- The Canister Storage Building was turned over to Operations for full control.

\section{SAFETY}

The project has achieved over 1,375,651 safe work hours. The past eleven of twelve months for the DOE Cost Index and Severity Rate have been below average. Although the SNF Project experienced some safety performance degradations with the start of FY 2000, performance continues to improve. October 1999 had two Restricted Workday Cases, and one Lost Away Workday Case. This was a nearly significant increase (close to but not above the UCL) on the Occupational Safety and Health Act (OSHA) Recordable Case Rate. 
The project's safety record is improving in both OSHA recordables and DOE Cost Index.

Lostaway overall has had only one case in the past year.
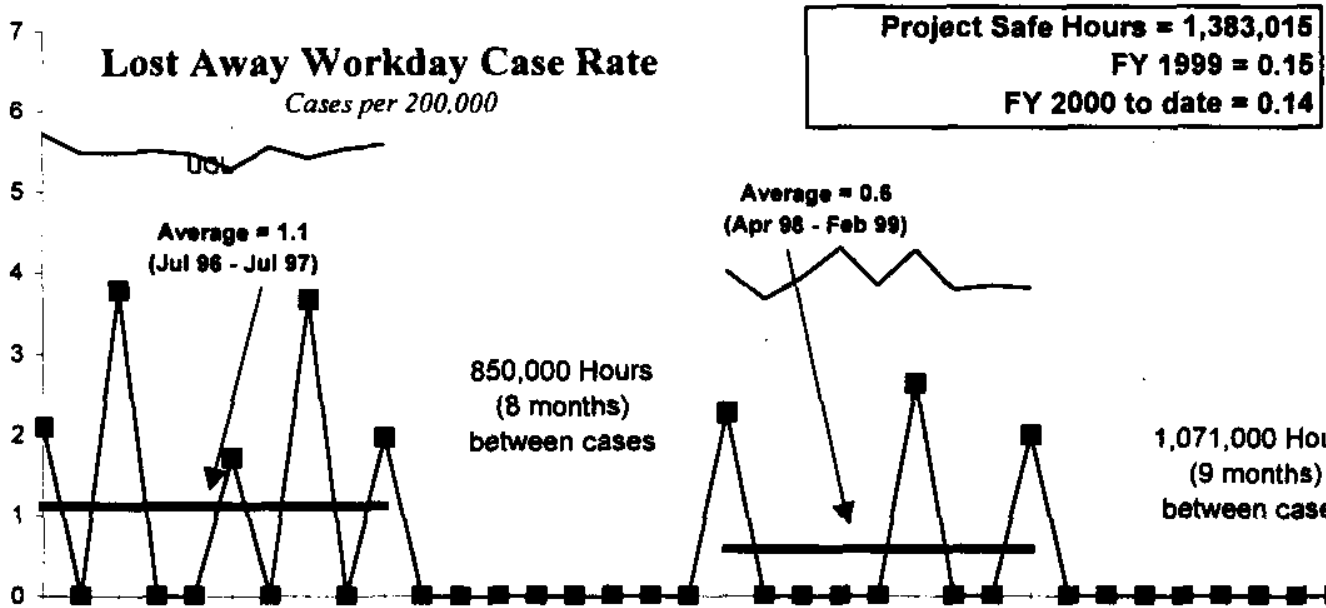

Green

FY 2000 to date $=0.14$

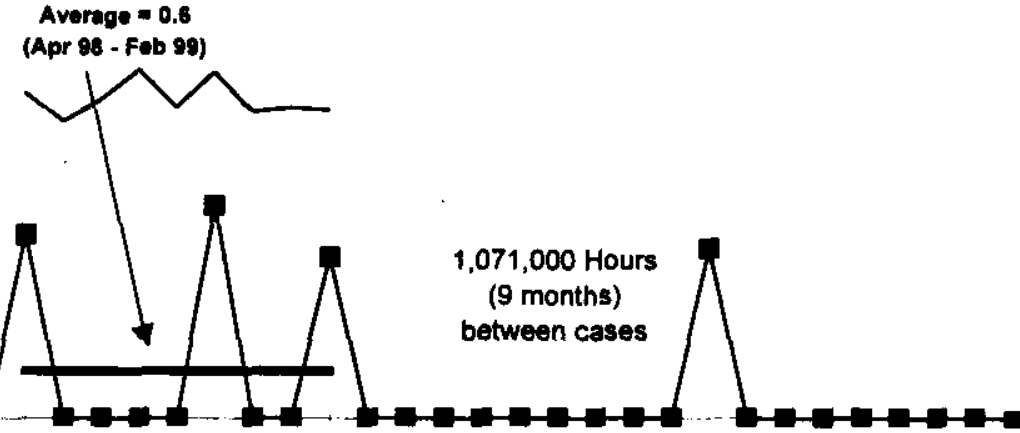

OSHA Recordable Case Rate

20 - Cases per 200,000

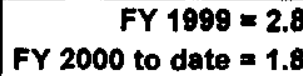

Green
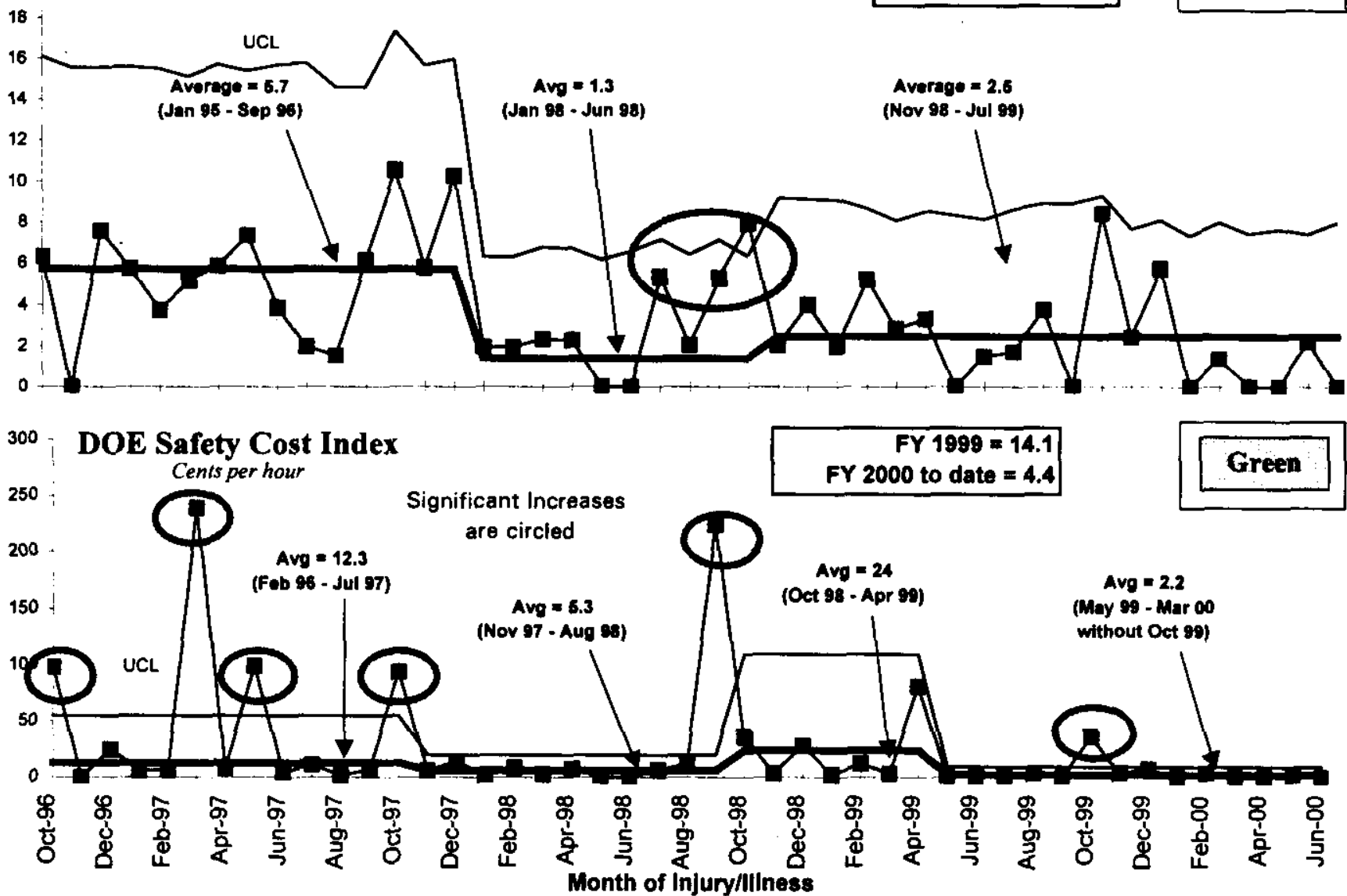


\section{CONDUCT OF OPERATIONS / ISMS STATUS}

CONDUCT OF OPERATIONS

Events per 200,000 hours
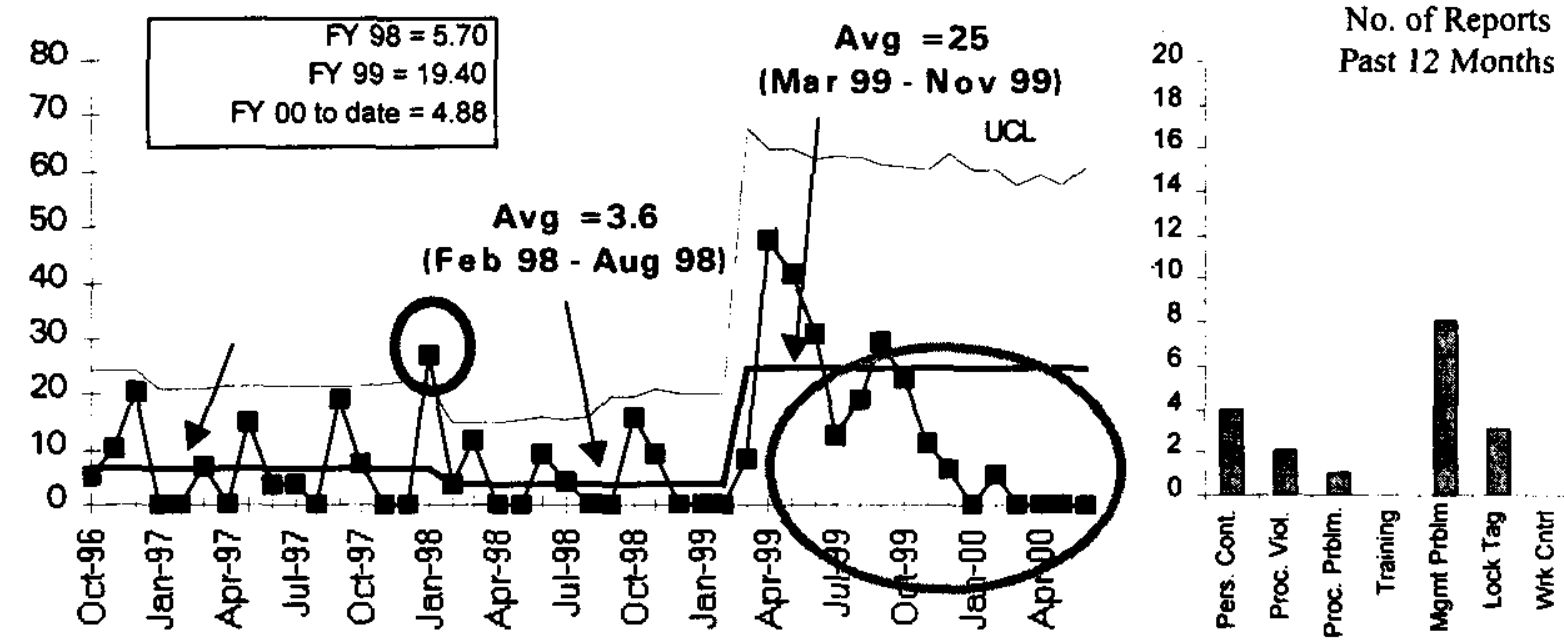

\section{ISMS STATUS}

\section{Green}

The ISMS Phase I/II verification for the SNF Project was completed on November 19, 1999.

- The Corrective Action Plans for the "Opportunities for Improvement" were developed and transmitted to RL on January 10, 2000.

- The actions required to enable ISMS implementation to be declared March 31, 2000 are now complete. Documentation packages have been transmitted to the Environmental, Safety and Health organization. Three of the four packages were reviewed as part of the Project Hanford Management Contract (PHMC) Phase I verification. These items are complete. The remaining item needing $\mathrm{RL}$ verification deals with Chemical Management Implementation and is awaiting availability of $\mathrm{RL}$ personnel to complete the review.

\section{BREAKTHROUGHS / OPPORTUNITIES FOR IMPROVEMENT}

\section{Breakthroughs}

Green

- Baseline Change Request SNF-2000-009, which accelerates the completion of sludge removal by one year from August 2005 to August 2004 and reduces total project life cycle cost by $\$ 16$ million, was implemented. 


\section{Opportunities for Improvement}

Phased Startup Initiative (PSI) - Results from the PSI are expected to improve the fuel production rates by approximately one month in FY 2001.

\section{UPCOMING ACTIVITIES}

Cold Vacuum Drying (CVD) Facility Testing - Testing at the CVD Facility continues to remain on the critical path. Completion of testing is scheduled for the end of August 2000.

Cask Loadout System (CLS) Testing — Complete startup testing by mid-August 2000.

Phased Startup Initiative (PSI) - Complete PSI Phases I and II in order to support start of Hot Testing by August 25, 2000 .

Storage Projects - Delivery of eight more Multi-Canister Overpacks (MCO) is expected by the end of August.

Fuel Removal Activities - Begin DOE Operations Readiness Review by late-September 2000. Begin K West Basin fuel removal, drying and storage operations by November 30, 2000.

Cost Performance (\$M):

\begin{tabular}{|l|l|l|c|}
\hline & BCWP & ACWP & VARIANCE \\
\hline Spent Nuclear Fuel & $\$ 153.3$ & $\$ 157.7$ & $-\$ 4.4$ \\
\hline
\end{tabular}

The unfavorable cost variance of $\$ 4.4$ million ( 3 percent) is primarily due to Hanford Site assessments higher than baseline and additional facility start up and engineering required as a result of first-of-a-kind equipment issues at $\mathrm{K}$ Basins and the CVD Facility.

\section{Schedule Performance ( $\$ M)$ :}

\begin{tabular}{|l|c|c|c|}
\hline & BCWP & BCWS & VARIANCE \\
\hline Spent Nuclear Fuel & $\$ 153.3$ & $\$ 154.0$ & $-\$ 0.7$ \\
\hline
\end{tabular}

The unfavorable schedule variance of $\$ 0.7$ million ( 0 percent) is within the established thresholds. 


\title{
Fy 2000 Cost/SChedule PerformanCe - All Fund Types Cumulative to Date Status - $(\$ 000)$
}

\author{
FYTD \\ By PBS

\begin{tabular}{llllllll}
\hline BCWS BCWP ACWP SV & $\%$ & CV & $\%$ & PEM & EAC
\end{tabular} \\ PBS WM01 Spent Nuclear \\ WBS 1.3 Fuel Project

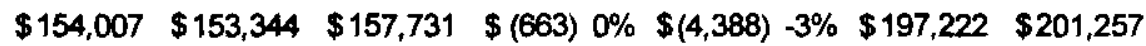 \\ Total

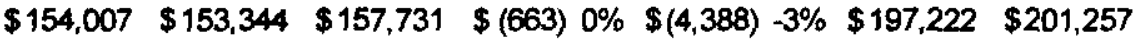

\section{Cost/Schedule Performance Indices (MONTHLY AND FYTD)}

Yellow

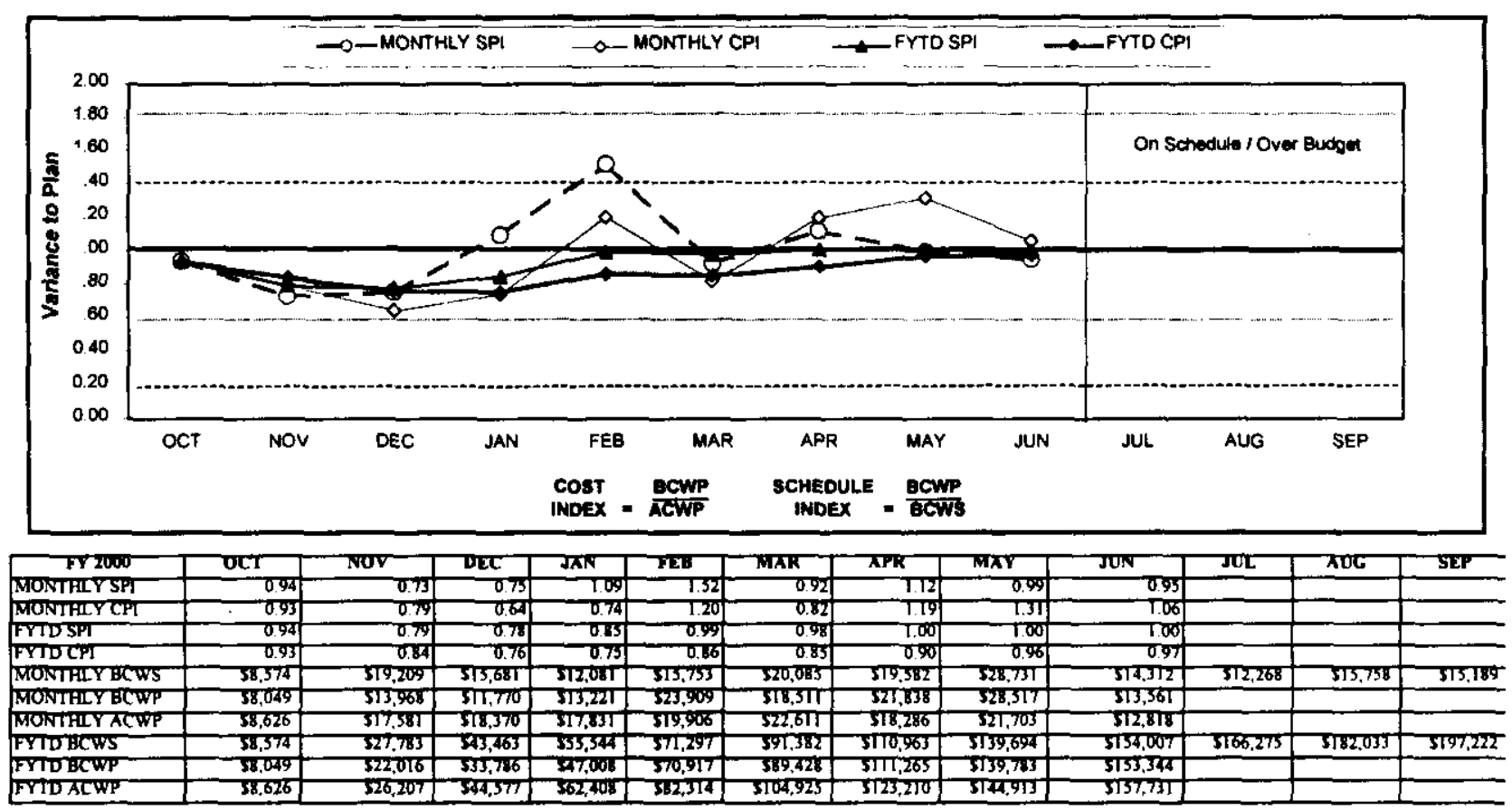

\section{COST VARIANCE ANALYSIS: (- \$4.4M)}

\section{$\underline{\text { WBS/PBS }}$}

\subsection{1/WM01}

Title

Hanford Site assessments higher than baseline and additional facility start up and engineering required as a result of first-of-a-kind equipment issues at $\mathrm{K}$ Basins and the CVD Facility.

Impact: The unanticipated site cost impacts, i.e., Corrective Action Management, Hanford Security, and fee allocation, are being compensated with appropriate site actions. In addition, Baseline Change Requests (BCRs) have been developed and reviewed and are on hold pending 
source availability for engineering, testing and administrative support. An \$8 million fiscal year end expense funding shortfall has been identified to $\mathrm{FH}$ and RL budget staff.

Corrective Action: Approve pending BCRs.

\section{SCHEDUle VARIANCE ANALYSIS: (\$0.7M)}

WBS/PBS

\subsection{1/ WM01} established thresholds.

Impact: None.

Corrective Action: None

\section{Title}

Spent Nuclear Fuel Project

\section{FUNDS MANAGEMENT FUNDS VS SPENDING FORECAST ( $\$ 000)$ FY TO DATE THROUGH JUNE 2000 (FLUOR HANFORD, INC. ONLY)}

\begin{tabular}{|c|c|c|c|c|c|c|c|c|c|}
\hline & \multicolumn{3}{|c|}{ Project complaton } & \multicolumn{3}{|c|}{ Pontzovis } & \multicolumn{3}{|c|}{ Lino intions } \\
\hline & Expectiod Funds & PYsF & Vartanea & Funds & FYsF & Vortunes & Fundis & Frof & Variance \\
\hline $\begin{array}{c}\text { Spent Nuclibar fuel } \\
\text { wavo Operating }\end{array}$ & 171,075 & 177,438 & $(6,363)$ & & & & & & \\
\hline Lino Item & & & & & & & 22,669 & 22,669 & $\$$ \\
\hline Total Spent Nucloar Fuel Oporating & \$ 171,076 & \$ 177,438 & $5(6,363)$ & & & & & & \\
\hline 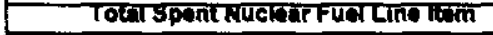 & & & & & & & 22,669 & 22,669 & $\mathbf{5}$ \\
\hline
\end{tabular}

\section{ISSUES}

There are no technical, DOE, Regulator or external issues identified at this time However, an internal DOE budget reprogramming of $\$ 5.0$ million will be allocated in August to remedy SNF's projected FY 2000 expense funding shortage. 


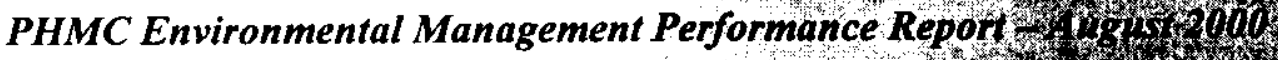

Section D-Spent Nuclear Fuel

\section{Baseline Change Requests Currently in Process (\$000)}

\begin{tabular}{|c|c|c|c|c|c|c|c|c|c|}
\hline $\begin{array}{l}\text { PROJECT } \\
\text { CHANGE } \\
\text { MUMBER }\end{array}$ & DATE ORIGIN. & BCR TILE & $\begin{array}{l}\text { COST } \\
\text { IMPACT } \\
5000\end{array}$ & SCH & TECH & $\begin{array}{l}\text { DATE TO } \\
\text { FOH CCB }\end{array}$ & $\begin{array}{l}\text { CCB } \\
\text { APRVD }\end{array}$ & $\begin{array}{c}\text { RL } \\
\text { APR'VD }\end{array}$ & CURRENT \\
\hline SNF-2000-019 & $5 / 9 / 00$ & FRS/WTS Phased Steriup Initiative & 2500 & $\mathrm{Y}$ & $Y$ & & & & In preparation. \\
\hline SNF-2000-001 & $6 / 13 / 00$ & CAMDTS Cost Allocation & 1311 & $\bar{N}$ & $\bar{Y}$ & & & & $\begin{array}{l}\text { FHCCB Cpproved BCR, } \\
7 / 12 / 100 \text {. Awaiting RL CO } \\
\text { epproval. }\end{array}$ \\
\hline SNF-2000-020 & $6 / 14 / 00$ & $\begin{array}{l}\text { Safeguards \& Security Support at } \\
\text { KE } M W \text { Basins and CVD Facilty }\end{array}$ & . & $\bar{Y}$ & $\bar{Y}$ & & & & In preparation. \\
\hline \multicolumn{10}{|c|}{ ADVANCE WORK AUTHORIZATIONS } \\
\hline & & Nothing to report. & & & & & & & \\
\hline
\end{tabular}

\section{SPENT NUCLEAR FUeLS - WBS 1.3 MILESTONE ACHIEVEMENT}

\begin{tabular}{|c|c|c|c|c|c|c|c|c|}
\hline \multirow[b]{2}{*}{ MILESTONE TYPE } & \multicolumn{4}{|c|}{ FISCAL YEAR-TO-DATE } & \multicolumn{3}{|c|}{ REMAINING SCHEDULED } & \multirow[b]{2}{*}{$\begin{array}{c}\text { TOTAL } \\
\text { FY } \\
2000\end{array}$} \\
\hline & $\begin{array}{c}\text { Completed } \\
\text { Early }\end{array}$ & \begin{tabular}{|c|} 
Completed \\
On \\
Schedule
\end{tabular} & $\begin{array}{l}\text { Completed } \\
\text { Late }\end{array}$ & Overdue & $\begin{array}{c}\text { Forecast } \\
\text { Early }\end{array}$ & $\begin{array}{c}\text { Forecast } \\
\text { On } \\
\text { Schedule }\end{array}$ & $\begin{array}{c}\text { Forecast } \\
\text { Late }\end{array}$ & \\
\hline Enforceable Agreemen & 2 & o & 0 & $\overline{0}$ & 0 & 0 & 0 & 2 \\
\hline DOE-HQ & 0 & 0 & 0 & 0 & $\overline{0}$ & 우 & 0 & 0 \\
\hline $\mathrm{RL}$ & 1 & 0 & 1 & $\underline{0}$ & $\underline{0}$ & 1 & 0 & 3 \\
\hline Total Project & 3 & 0 & 1 & 0 & 0 & 1 & $\underline{0}$ & 5 \\
\hline
\end{tabular}


PHMC Environmental Management Performance Report 3 w

Section D-Spent Nuclear Fuel

Status as of $7 / 24 / 2000$

Green

Tri-Party Agreement / EA Milestones

\begin{tabular}{|l|l|l|}
\hline \multicolumn{1}{|c|}{ Number } & \multicolumn{1}{|c|}{ Milestone Title } & \multicolumn{1}{c|}{ Status } \\
\hline $\begin{array}{l}\text { M-34-14A } \\
\text { (S06-97-009) }\end{array}$ & $\begin{array}{l}\text { "Complete K West Basin Cask } \\
\text { Facility Modules" }\end{array}$ & $\begin{array}{l}\text { Due 2/29/00 - Completed on } \\
\text { schedule. }\end{array}$ \\
\hline $\begin{array}{l}\text { M-34-04 (S01- } \\
\text { 99-124) }\end{array}$ & $\begin{array}{l}\text { "Submit Remedial Design } \\
\text { Report/Remedial Action Work } \\
\text { Plan for the K Basins" }\end{array}$ & $\begin{array}{l}\text { Due 3/31/00 - Completed over one } \\
\text { month early (February 10, 2000). }\end{array}$ \\
\hline $\begin{array}{l}\text { M-34-05 (T01) } \\
\text { "Submit Report on Quantities, } \\
\text { Character, and Management of K } \\
\text { B1-900) }\end{array}$ & $\begin{array}{l}\text { Due 5/31/00 - Completed on } \\
\text { Schedule. }\end{array}$ \\
\hline $\begin{array}{l}\text { M-34-06-T01 } \\
\text { Basins Debris" }\end{array}$ & $\begin{array}{l}\text { "Initiate removal of K West } \\
\text { Buclear Fuel Canister Cleaning } \\
\text { Operations" }\end{array}$ & Due 11/30/00 - On schedule. \\
\hline
\end{tabular}

DNFSB Commitments

\begin{tabular}{|l|l|l|}
\hline & Nothing to report. & \\
\hline & & \\
\hline
\end{tabular}

\section{MILESTONE EXCEPTION REPORT}

Nothing to report.

\section{Performance Objectives}

Readiness for Fuel Movement (RC-1-1.a-I) - Contractor completion of construction and operational testing, Management Self-Assessment (MSA), and Independent Operational Readiness Review (ORR) by September 14, 2000 Yellow to begin moving fuel by November 30,2000 . Start of fuel movement is currently on track for November 30, 2000.

Phased Startup Initiative (PSI) (RC-1-1.a-II) - Complete PSI Phases 1 and 2 by April 15, 2000. This includes successful Cold Testing of Integrated Water Treatment System (IWTS) and Fuel Retrieval System (FRS).

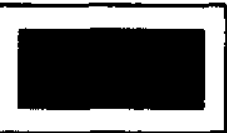
This activity is behind schedule due to required changes to the IWTS Control System Software. This accelerated non-critical path testing activity continues to allow KW Basin system problems to be uncovered and fixed much earlier that the baseline schedule.

Accelerate Fuel Movement (RC-1SS-1) - Accelerate start of fuel movement by two months. Pre-positioning of fuel processed in PSI Phase III will allow Yellow early loading of Multicanister Overpacks (MCOs). Assumes IWTS testing completes without 
further delay, no problems during first fuel movement, and minimum ORR discrepancies.

Phased Startup Initiative (PSI) (RC-1SS-2) — Complete Phases three and four by August 15, 2000. This includes completion of FRS/IWTS system testing using SNF (real fuel) and Completion of Construction Documentation Phase II

(CCD2). PSI Phases III \& IV are currently being restructured to reflect the delay caused by the IWTS Control System software failure.

\section{KEY INTEGRATION ACTIVITIES}

- Spent nuclear fuel (SNF) final disposition interface activities, including Office of Civilian Radiation Waste Management (OCRWM) Quality Assurance (QA) Program implementation, ongoing with National SNF Program.

- $\quad$ K Basins sludge removal and Shippingport (PA) Pressurized Water Reactor Core 2 SNF removal implementation activities ongoing with Waste Management Project.

- $\quad 324$ Building (B Cell) SNF removal acceptance criteria and conceptual design reviews ongoing with River Corridor Project.

- Neutron Radiography Facility, Training, Research and Isotope Production, General Atomics (TRIGA), and Fast Flux Test Facility (FFTF) SNF relocation planning ongoing with FFTF Project.

- Input provided to Bechtel Hanford, Incorporated (BHI) on recovery actions required if SNF is discovered during upcoming reactor basins deactivation.

- Completed assessment and documentation for the Canister Storage Building's readiness to support the receipt of Immobilized High Level Waste (IHLW) from Occurrence Reporting Program (ORP). 


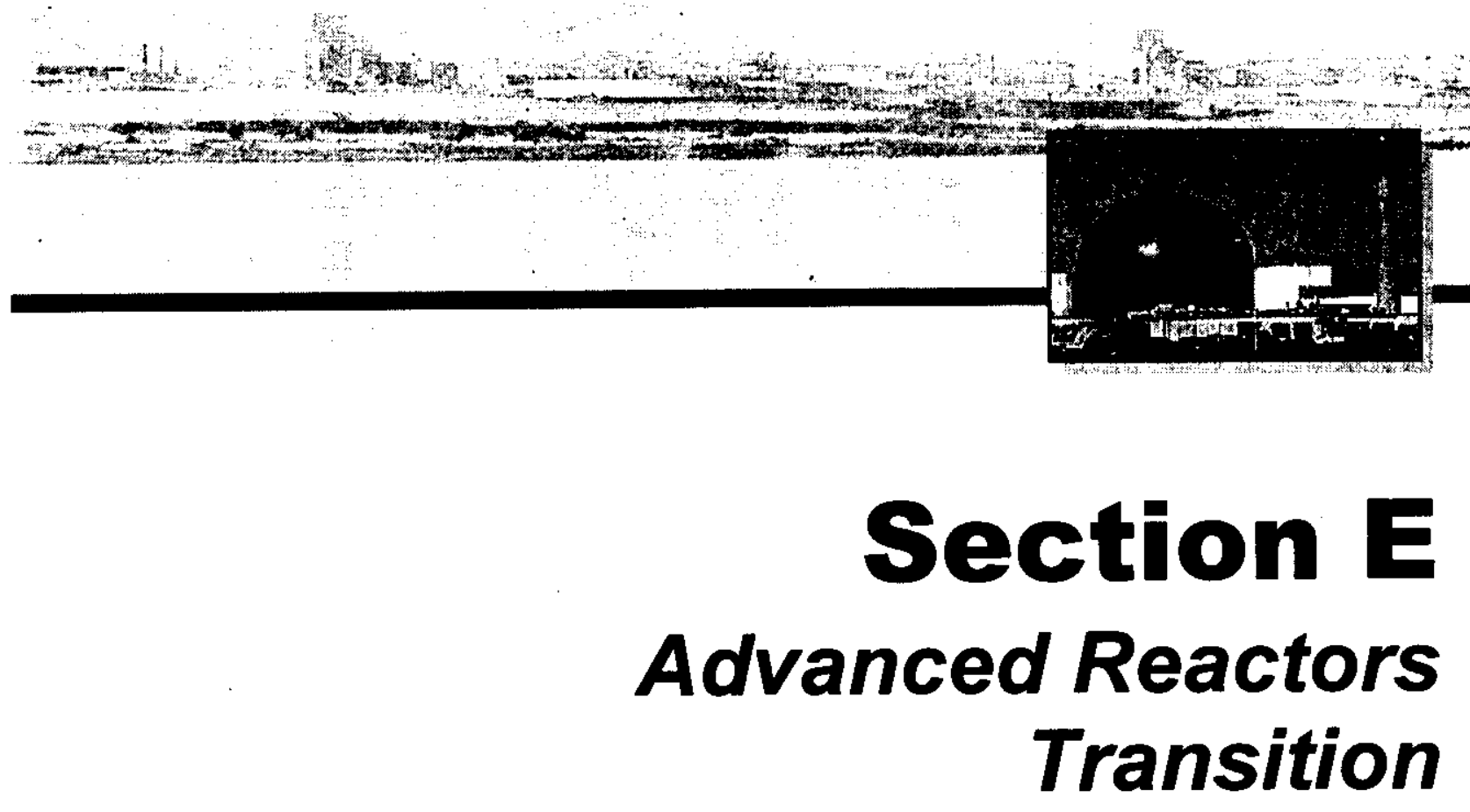

PROJECT MANAGERS

O.A. Farabee, RL

(509) 376-8089

D.B. Klos, FH

(509) 373-3574 


\section{SUMMARY}

The Advanced Reactors Transition (ART) Program, WBS 1.12.1.1, PBS RL-TP11, consists of the 309 Building and the Nuclear Energy (NE) Legacies activities.

NOTE: Cost/Schedule data contained herein is as of June 30,2000. All other information is as of July 20,2000 , unless otherwise noted.

In June the ART mission area technical accomplishments included continued surveillance and maintenance activities on the 309 Building and NE Legacy facilities. The Fast Flux Test Facility (FFTF) Plant Review Committee approved starting the reaction of residual Sodium Potassium $(\mathrm{NaK})$ in the 337B cold trap cooling system, subject to completion of punchlist items. A small amount of $\mathrm{NaK}$ (grams) was drained from the low spots in the system in order to obtain a better flow path for the water vapor-nitrogen reaction process. Separation of the cooling system into two parts to obtain better flow control of the water vapor-nitrogen process was completed, and the cleaning station was connected to the "loop side" of the separated system. The argon cover gas is being maintained on both sides of the system. Nitrogen flow through the loop side of the residual NaK in the 337B cold trap cooling system started July 11, 2000.

Fiscal-year-to-date milestone performance (EA, DOE-HQ, and RL) shows that there are no milestones due.

\section{ACCOMPLISHMENTS}

- Continued surveillance and maintenance activities on 309 Building and NE legacies.

- The FFTF Plant Review Committee approved starting the reaction of residual NaK in the $337 \mathrm{~B}$ cold trap cooling system, subject to completion of punchlist items.

- A small amount of $\mathrm{NaK}$ (grams) was drained from the low spots in the system in order to obtain a better flow path for the water vapor-nitrogen reaction process

- Separation of the $\mathrm{NaK}$ cooling system into two parts to obtain better flow control of the water vapor-nitrogen process was completed, and the cleaning station was connected to the "loop side" of the separated system.

- Nitrogen flow through the loop side of the residual $\mathrm{NaK}$ in the 337 cold trap cooling system started July $11,2000$.

\section{SAFETY}

Safety data for ART is included in a separate FFTF report. 


\section{CONDUCT OF OPERATIONS / ISMS STATUS CONDUCT OF OPERATIONS}

Conduct of operations data for ART is included in a separate Fast Flux Test Facility (FFTF) report.

\section{ISMS STATUS}

ISMS Readiness Assessment Phase II was completed during the reporting period with excellent results.

\section{BREAKTHROUGHS / OPPORTUNITIES FOR IMPROVEMENT}

No breakthroughs or opportunities for improvement have been identified at this time.

\section{UPCOMING ACTIVITIES}

- $\quad$ Continue with cleaning of the sodium potassium (NaK) residuals from the 337B Building cold trap cooling loop.

- Initiate Fuel Transfer Pit cleanout in the 309 Building/PRTR facility.

\section{Cost Performance (\$M):}

\begin{tabular}{|l|c|c|c|}
\hline & BCWP & ACWP & VARIANCE \\
\hline Advanced Reactors Transition & $\$ 1.1$ & $\$ 1.0$ & $\$ 0.1$ \\
\hline
\end{tabular}

The favorable $\$ 0.1 \mathrm{M}$ (10 percent) cost variance is due to no significant corrective maintenance activities required.

\section{Schedule Performance $(\$ M):$}

\begin{tabular}{|l|c|c|c|}
\hline & BCWP & BCWS & VARIANCE \\
\hline Advanced Reactors Transition & $\$ 1.1$ & $\$ 1.1$ & $\$ 0.0^{*}$ \\
\hline
\end{tabular}

- Due to rounding, variance indicates zero dollars, however there is a schedule variance of $(\$ 55 \mathrm{~K})$ addressed in this report.

The unfavorable $-\$ 0.1 \mathrm{M}$ ( 5 percent) schedule variance is due to splitting the $\mathrm{NaK}$ system into two parts for better flow control. The result was not being able to finish some tasks, including design and construction of connecting piping, when originally planned. 


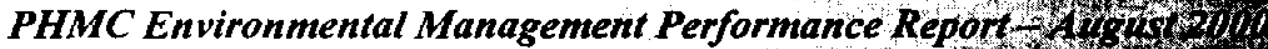

Section E-Advanced Reactors Transition (ART)

\section{FY 2000 Cost/SChedule Performance - All Fund Types Cumulative to Date Status - $(\$ 000)$ \\ FYTD}

By PBS

$\begin{array}{llllllll}\text { BCWS BCWP ACWP } & \text { SV } & \% & \text { CV } & \% & \text { PEM } & \text { EAC }\end{array}$

PBS TPll Advanced Reactors

WBS 1.12 Transition

$\begin{array}{llllllllllllll}\$ 1,143 & \$ 1,088 & \$ 977 & \$(55) & -5 \% & \$ 111 & 10 \% & \$ 1,673 & \$ 1,318\end{array}$

Total

$\begin{array}{llllllllllllll}\$ & 1,143 & \$ 1,088 & \$ 977 & \$(55) & -5 \% & \$ & 111 & 10 \% & \$ 1,673 & \$ & 1,318\end{array}$

\section{Cost/Schedule Performance Indices (MONTHLY AND FYTD)}

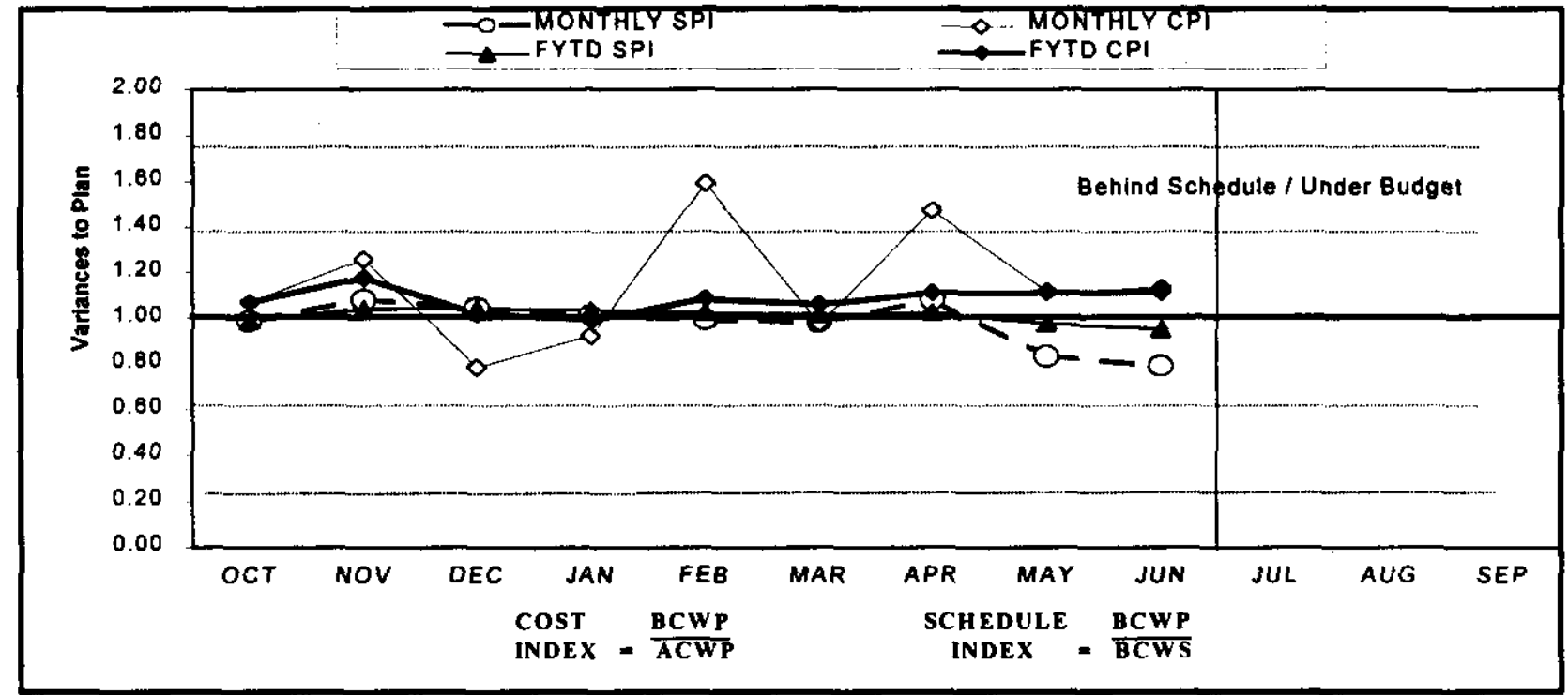

\begin{tabular}{|c|c|c|c|c|c|c|c|c|c|c|c|c|}
\hline FY2000 & OCT & Nov & DEC & JAT & FEB & MAR & APR & MAY & JUN & JUL & AUG & SEP \\
\hline MONTHLY SPI & 0.99 & 1.08 & 1.05 & 1.07 & 0.99 & 0.98 & 7.08 & 0.83 & 0.79 & & & \\
\hline MONTRIYY CPI & 1.07 & 1.26 & 0.79 & 0.92 & T.59 & 0.97 & 1.47 & $T .12$ & T.T3 & & & \\
\hline FYTDSPT & 0.99 & 1.04 & T.04 & $\pi .03$ & $T .02$ & T.0T & $T .02$ & 0.98 & 0.95 & & & \\
\hline FYTDCP & 1.07 & T.T8 & 1.02 & 0.99 & 1.09 & 1.06 & T. & T.T & T.IT & & & \\
\hline MONTHLYBCWS & 579 & \$Tा3 & 588 & 593 & $\$ 176$ & 5139 & 3Tा6 & 5254 & 3746 & 3144 & 3196 & डाशा \\
\hline MONTHLY BCWP & 578 & 3722 & 392 & 394 & STIS & 3736 & 3125 & $32 \pi$ & 5TT5 & & & \\
\hline MONTHLY ACWP & 573 & 397 & STIT & 5102 & 572 & 5ा40 & 385 & $\$ 189$ & 3702 & & & \\
\hline FYTD BCWS & 579 & 5192 & 5280 & $53 / 3$ & 3489 & 5627 & 5743 & $\$ 997$ & 31,143 & 37,286 & $\$ 1,483$ & 31.673 \\
\hline FYTDBCWP & 578 & 5200 & $\$ 292$ & $\$ 386$ & 3501 & $\$ 637$ & 5761 & 3972 & 37,088 & & & \\
\hline FYTD ACWP & 573 & 5170 & 3287 & 5389 & $\$ 461$ & 5601 & 5686 & 3875 & 3977 & & & \\
\hline
\end{tabular}

Note: Contains RL-TP11 


\section{COST VARIANCE ANALYSIS: $(+\$ 0.1 \mathrm{M})$}

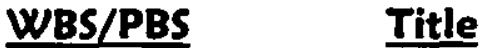

\subsection{2/TP11 Advanced Reactors Transition}

Description and Cause: All Surveillance and Maintenance (S\&M) resources were level loaded for the year. To date, no significant corrective maintenance activities have been required.

Impact: None.

Corrective Action: None.

\section{SCHEDULE VARIANCE ANALYSIS: $(-\$ 0.1 \mathrm{M})$}

\section{WBS/PBS Title}

\subsection{2/TP11 Advanced Reactors Transition}

Description and Cause: The unfavorable $-\$ 0.1 \mathrm{M}(5$ percent) schedule variance is due to splitting the NaK system into two parts for better flow control, resulting in not being able to finish some tasks, including design and construction of connecting piping, when originally planned.

Impact: None.

Corrective Action: None.

\section{FUNDS MANAGEMENT FUNDS US SPENDING FORECAST ( $\$ 000)$ FY TO DATE THROUGH JUNE 2000 (FLUOR HANFORD, INC. ONLY)}

\begin{tabular}{|c|c|c|c|c|c|c|c|c|c|c|}
\hline & \multicolumn{3}{|c|}{ Projoct Completion " } & \multicolumn{3}{|c|}{ Post 2006 } & \multicolumn{3}{|c|}{ Line Items * } \\
\hline & & $\begin{array}{l}\text { Expoctod } \\
\text { Funds }\end{array}$ & FYSF & vertance & $\begin{array}{l}\text { Expocind } \\
\text { Funds }\end{array}$ & FYSF & Vertance & $\begin{array}{l}\text { Expocted } \\
\text { Funds }\end{array}$ & FYSF & Vartence \\
\hline \multicolumn{11}{|c|}{ The Rlver } \\
\hline & Total Advanced Reactors Operating & & & & 4,172 & $\mathbf{3 , 7 1 8}$ & $\$ 454$ & & & \\
\hline & Total Advanced Reactors Lino litem & & & & & & & & & \\
\hline
\end{tabular}

- Non Defense Control Point (EX)

\section{ISSUES}

There is nothing to report at this time. 
PHMC Environmental Management Performance Report - Atgust 20

Section E-Advanced Reactors Transition (ART)

\section{Baseline Change Requests Currently in Process}

\begin{tabular}{|c|c|c|c|c|c|c|c|c|c|}
\hline $\begin{array}{l}\text { PROJECT } \\
\text { CHANGE } \\
\text { NUMBER } \\
\end{array}$ & $\begin{array}{c}\text { DATE } \\
\text { ORIGIN. }\end{array}$ & BCR TITLE & $\begin{array}{c}\text { FY00 } \\
\text { COST } \\
\text { IMPACT } \\
\text { S000 } \\
\end{array}$ & $\underline{\mathrm{SCH}}$ & TECH & $\begin{array}{c}\text { DATE } \\
\text { TOCCB } \\
\end{array}$ & $\begin{array}{c}\text { CCB } \\
A R^{\prime} \text { D }\end{array}$ & $\begin{array}{c}\mathbf{R L} \\
\text { APR'VD } \\
\end{array}$ & $\begin{array}{c}\text { CURRENT } \\
\text { STATUS } \\
\end{array}$ \\
\hline & & Nothing to report. & & & & & & & \\
\hline \multicolumn{10}{|c|}{ ADVANCE WORK AUTHORIZATIONS } \\
\hline & & Nothing to report. & & & & & & & \\
\hline
\end{tabular}

\section{Milestone ACHIEVEMENT}

Fiscal-year-to-date milestone performance (EA, DOE-HQ, and RL) shows that there are no milestones due.

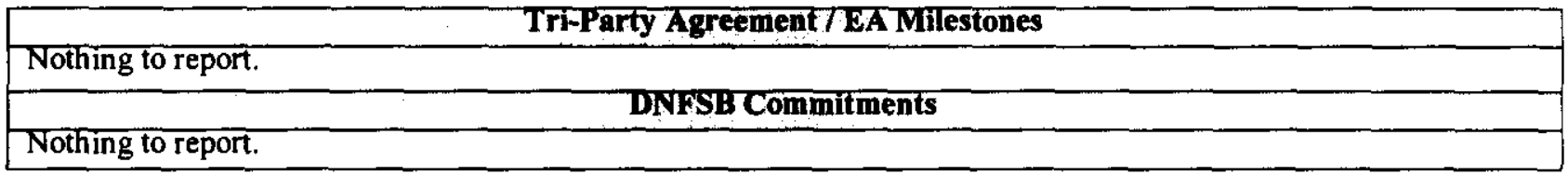

\section{MILESTONE EXCEPTION REPORT}

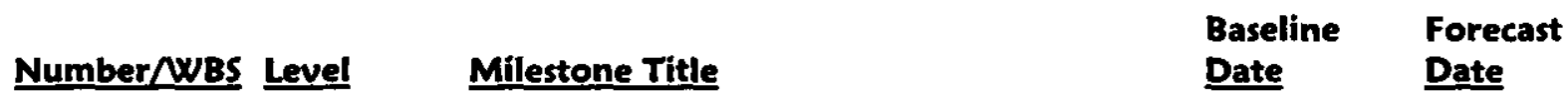

\section{OVerdue - 0}

\section{FORECAST LATE - 0}

\section{Performance Objectives}

Nothing to report at this time.

\section{KEY INTEGRATION ACTIVITIES}

Nothing to report at this time. 

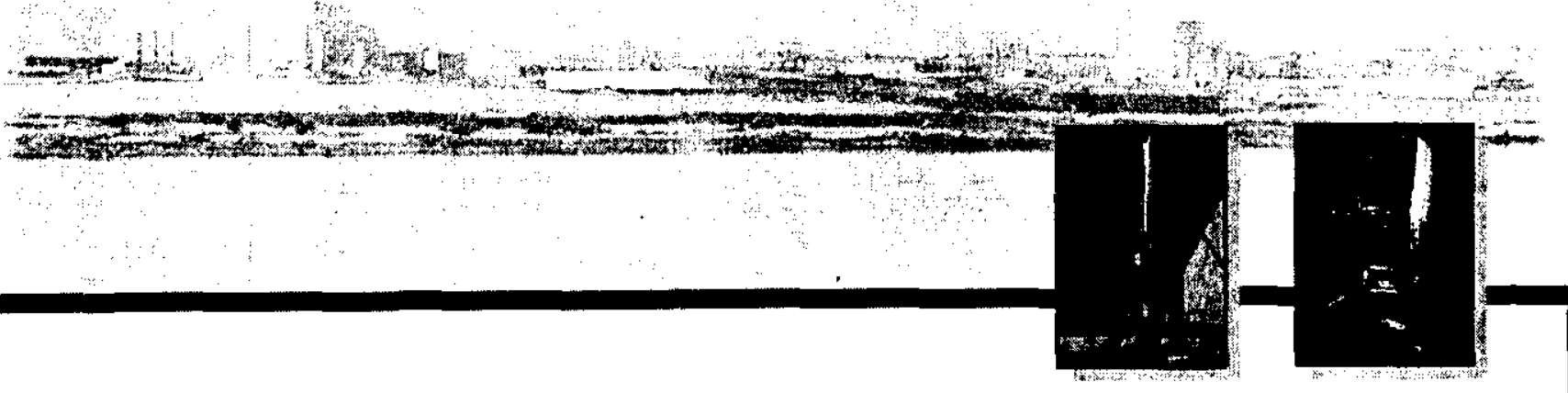

\section{Section F \\ $E M-50$}

\section{Science \& Technology Activities}


PHMC Environmental Management Performance Repont Augus $700 \%$

Section $F-E M-50$

EM-50 MILESTONE ACHIEVEMENT

\begin{tabular}{|c|c|c|c|c|c|c|c|c|}
\hline \multirow[b]{2}{*}{ MILESTONE TYPE } & \multicolumn{4}{|c|}{ FISCAL YEAR-TO-DATE } & \multicolumn{3}{|c|}{ REMAINING SCHEDULED } & \multirow[b]{2}{*}{$\begin{array}{l}\text { TOTAL } \\
\text { FY } 2000\end{array}$} \\
\hline & Completed Early & $\begin{array}{c}\text { Completed On } \\
\text { Schedule }\end{array}$ & $\begin{array}{l}\text { Completed } \\
\text { Late }\end{array}$ & Overdue & $\begin{array}{l}\text { Forecast } \\
\text { Early }\end{array}$ & $\begin{array}{c}\text { Forecast } \\
\text { On } \\
\text { Schedule }\end{array}$ & $\begin{array}{c}\text { Forecast } \\
\text { Late }\end{array}$ & \\
\hline Enforceable Agreement & 0 & 0 & 0 & 0 & $\underline{0}$ & 0 & 0 & 0 \\
\hline DOE-HQ & 0 & of & $\underline{0}$ & 0 & 0 & 1 & 0 & 1 \\
\hline $\mathrm{RL}$ & 0 & 0 & $\overline{1}$ & 0 & 0 & 1 & 0 & 2 \\
\hline Total Project & 0 & 0 & 1 & 0 & 0 & 2 & 0 & \\
\hline
\end{tabular}

\section{EM-50 Exceptions}

Number Level Milestone Title Date Date

There are no milestone exceptions. 


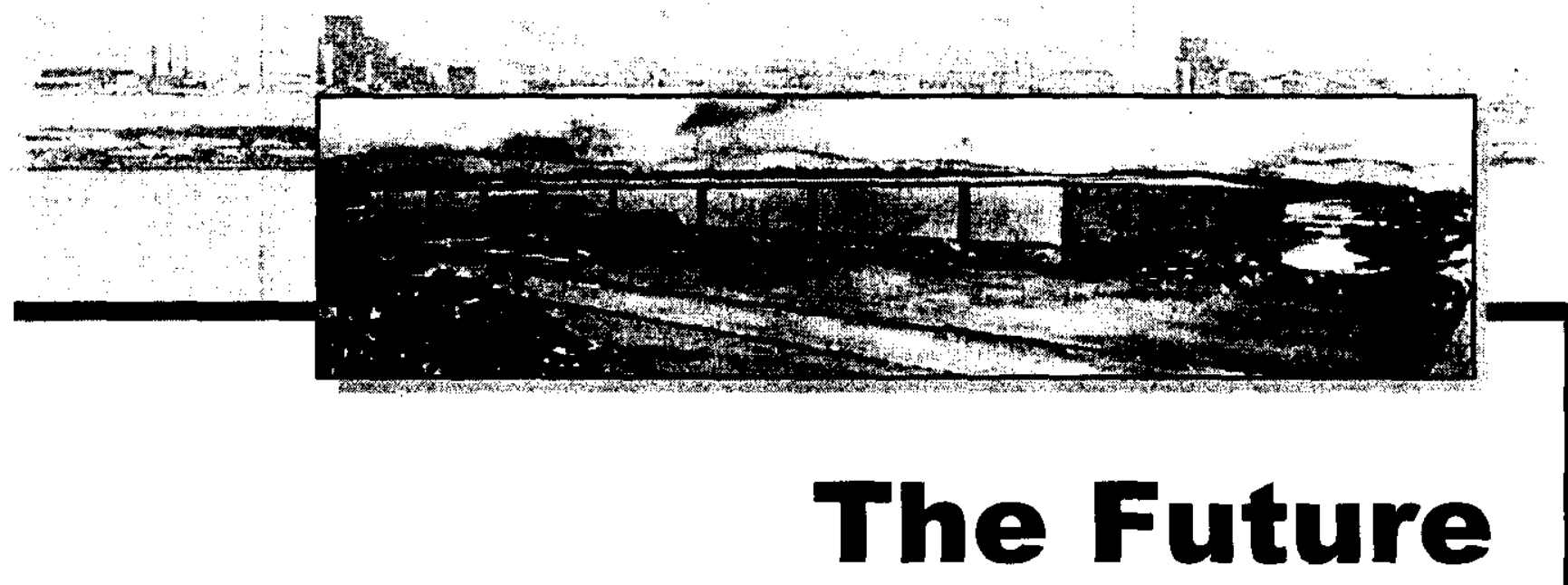

Hanford cleanup activities develop assets - people, experience, land, buildings, research and training facilities - that can have a positive affect on our future. They can help solve national and global problems in food production, global warming, pollution and nuclear non-proliferation. The prime contractors and subcontractors at Hanford are implementing economic development initiatives aimed at weaning the Tri-Cities from dependence on federal cleanup dollars. These initiatives are being supported with grants and by freeing up valuable site resources for use by the private sector. Examples of these initiatives are a new industrial building to attract new businesses to the area, job-creation efforts, and providing technical assistance to entrepreneurs. The Volpentest HAMMER Training and Education Center is included in this outcome. HAMMER provides training for the Hanford Site cleanup mission and the DOE complex. The Center also augments economic diversification by creating a state-of-the-art regional training industry for students from across the nation and around the world. 


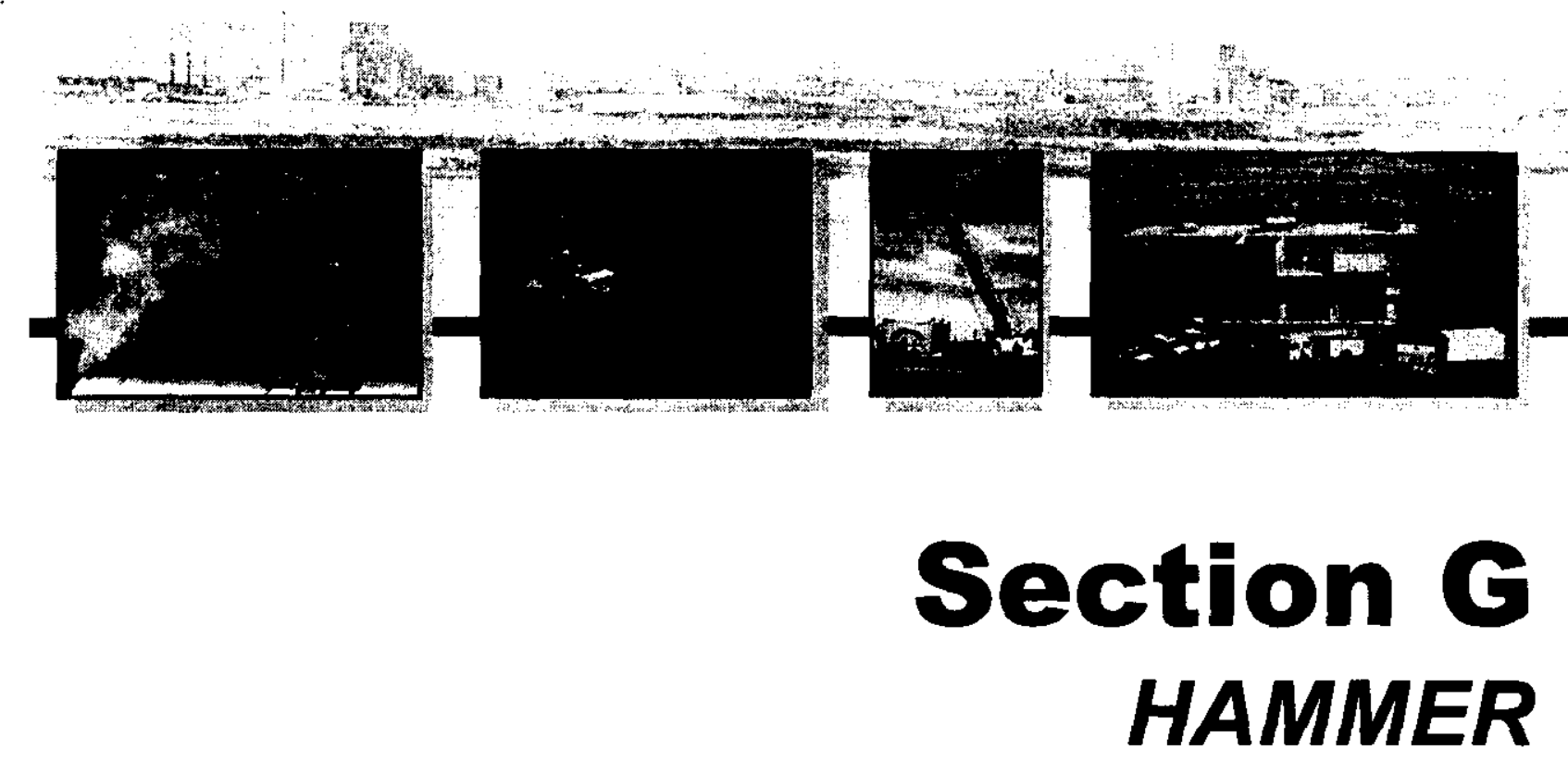

PROJECT MANAGERS

J.E. Ollero, RL

(509) 376-3825

K.A. McGinnis, FH

(509) 376-9403 


\section{SUMMARY}

The Hazardous Materials Management and Emergency Response (HAMMER) mission area consists of the HAMMER project, WBS 1.9.1.1, Project Baseline Summary (PBS) HM01.

NOTE: Unless otherwise noted, the Safety, Conduct of Operations, Milestone Achievement, and Cost/Schedule data contained herein is as of the end of June 2000. All other information is as of July $21,2000$.

Volpentest HAMMER's first priority is to deliver hands-on training to the Hanford workforce. During June one hundred forty-nine classes were conducted at the Volpentest HAMMER facility, for a total of 2,348 Hanford site student days. Highest attended health and safety classes included Hazardous Waste Operations, Respiratory Protection, Radiation Worker II

Requalification, Basic Crane and Rigging and Fire Extinguisher training. Overall satisfaction, rated on a scale from one to five based on level one evaluations, for the month of June: Course Content 4.49, Instructor(s) 4.50, and Facility 4.56.

The Hanford Incident Command System Refresher (Course \#038105) web-based training course was piloted on June 1, 2000. Currently, comments from Hanford Site Emergency Preparedness (EP) personnel and refresher students are being compiled for the final revision/approval phase.

The Building Emergency Director Refresher (course \#037515) web-based training course was piloted on June 30, 2000. Currently, comments from Hanford Site EP personnel and refresher students are being compiled for the final revision/approval phase.

University of Washington Occupational Safety and Health Association (OSHA) Education Center, Spring-Summer 2000 Safety \& Health Certificate Institute and HAMMER are proud to announce the recent graduation of students from the Safety and Health Specialist Certificate Program. Of the 12 June graduates, nine are employed at the Hanford site and received this training at HAMMER through distance learning.

Funding is in place and the Director of the Northwest Public Power Association's (NWPPA) National Utility Training Site has been selected. Bill Ryan, Director, National Utility Training will make his office at HAMMER to ensure close communication with the DOE and Fluor Hanford during the design and construction of this 40 acre prop. The groundbreaking ceremony has been scheduled for October 5, 2000 at 1:00 PM at the HAMMER. This prop will meet the hands-on-training needs of workers for the member organizations of the NWPPA and of Hanford site high-risk electrical workers.

The contract for the HAMMER-sponsored class, Global Positioning System (GPS), has been finalized and signed by Environmental and Waste Management Transportation (E\&WM) and GPS. The class is scheduled for August 22-25, 2000. A meeting with the Fluor Hanford (FH) personnel will be held on August 21, 2000 to discuss their specific equipment.

E\&WM is holding discussions with $\mathrm{FH}$ personnel responsible for the demonstration of the lasercutting tool. They are considering using the HAMMER facility for demonstrating the capability 
of this tool and, hopefully, holding future training sessions here at HAMMER.

Fiscal-year-to-date milestone performance (EA, DOE-HQ and RL) shows that one milestone (100 percent) was completed late.

\section{ACCOMPLISHMENTS}

- $\quad$ Trained 2,348 Hanford site student days at HAMMER.

- Piloted the Hanford Incident Command System Refresher (Course \#038105) as a webbased training course.

- $\quad$ Piloted the Building Emergency Director Refresher (Course \#037515) as a web-based training course.

- Graduated 12 students from the OSHA Education Center, Spring-Summer 2000 Safety and Health Certificate Institute and HAMMER.

- Selected the Director and finalized funding for the NWPPA National Utility Training Site.

- $\quad$ Finalized contract for the HAMMER-sponsored GPS class.

- $\quad$ Conducted discussions with FH personnel for demonstrating the laser-cutting tool for future training sessions at HAMMER.

HAMMER currently has no status to report in the areas of ISMS Status, Breakthroughs and Opportunities for Improvement.

\section{UPCOMING ACTIVITIES}

- $\quad$ The Fire Operations Product Line will be developing programs that employ HAMMER props to train individuals who must meet new technical rescue standards.

- The Fire Operations Product Line is working with the U.S. Forest Service to establish training plans for fire fighters that rappel from helicopters. The rappelling course may involve construction of a new prop that could be used for other types of training - SWAT responders and military customers, for instance.

- An International Customs class will be conducted in September 2000.

- A GPS equipment training course has been scheduled for August 2000.

- An Archeological Resources Protection Act Incident Investigation class has been scheduled for October 2000. 


\section{COST PerformanCe (\$M):}

\begin{tabular}{|l|c|c|c|}
\hline & BCWP & ACWP & VARIANCE \\
\hline HAMMER & $\$ 4.2$ & $\$ 4.0$ & $\$ 0.2$ \\
\hline
\end{tabular}

The favorable cost variance of $\$ 0.2 \mathrm{M}$ (6 percent) is within established thresholds.

\section{Schedule Performance (\$M):}

\begin{tabular}{|l|c|c|c|}
\hline & BCWP & BCWS & VARIANCE \\
\hline HAMMER & $\$ 4.2$ & $\$ 4.4$ & $-\$ 0.2$ \\
\hline
\end{tabular}

The unfavorable schedule variance of $\$ 0.2 \mathrm{M}$ (5 percent) is within established thresholds.

\section{FY 2000 COSt/SChedule Performance - All Fund Types Cumulative to Date Status - $(\$ 000)$}

By PBS

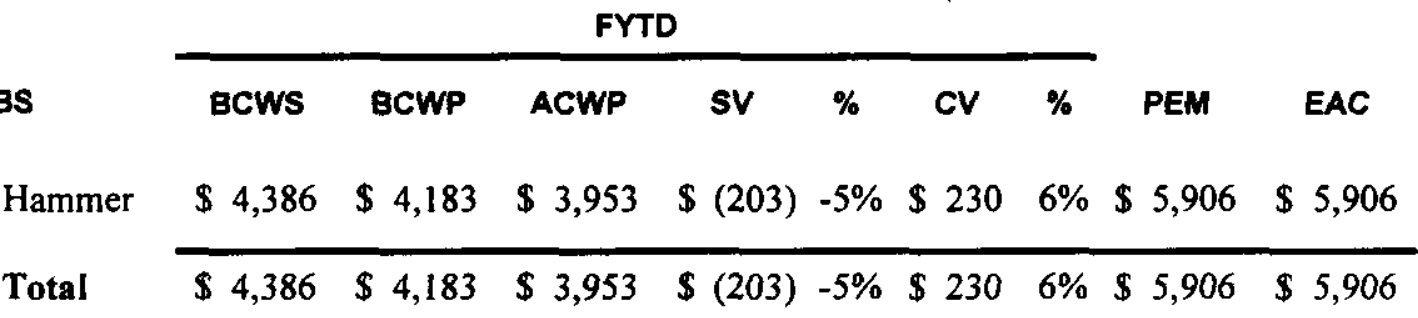

PBS HM01

WBS 1.9.1

Total 


\section{Cost/Schedule Performance Indices (MONTHLY 2000 AND FYTD)}

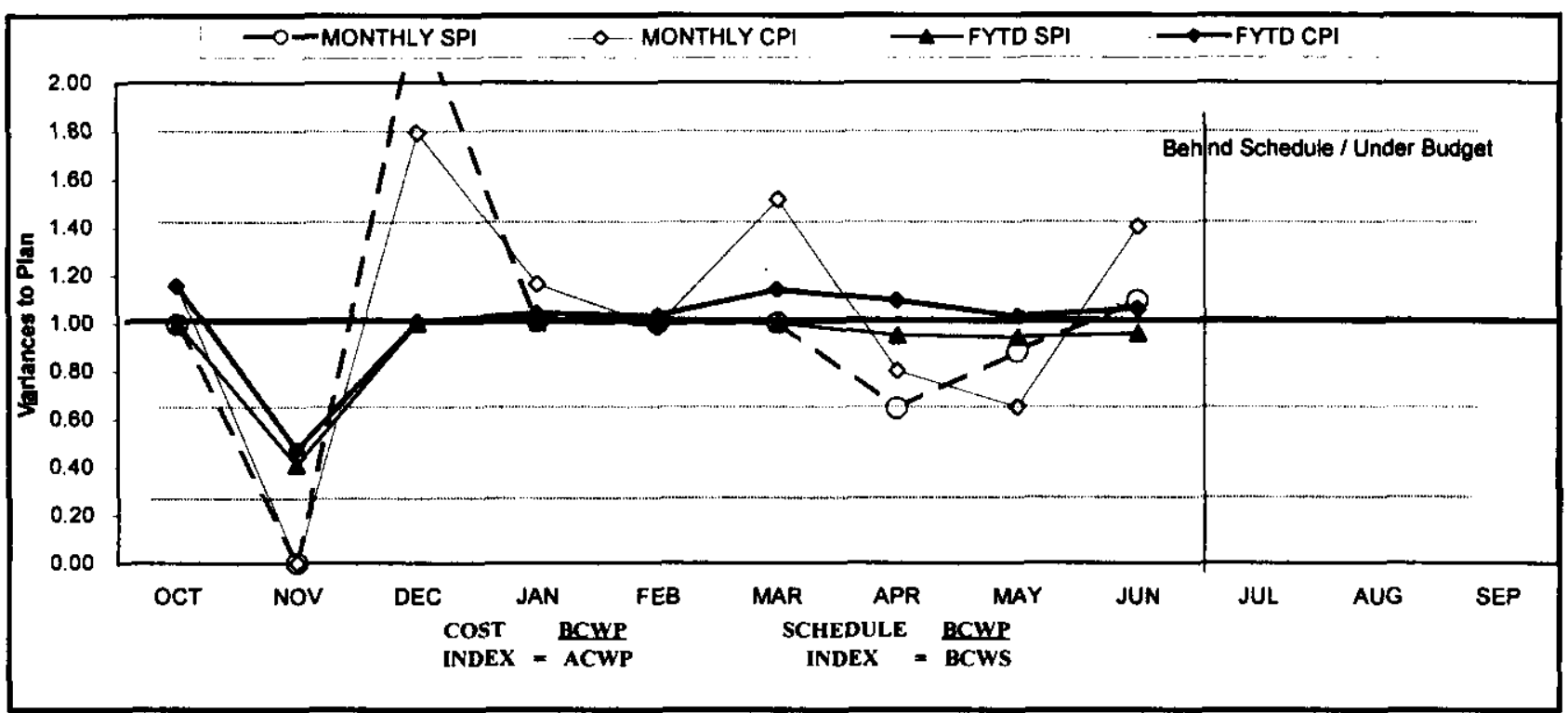

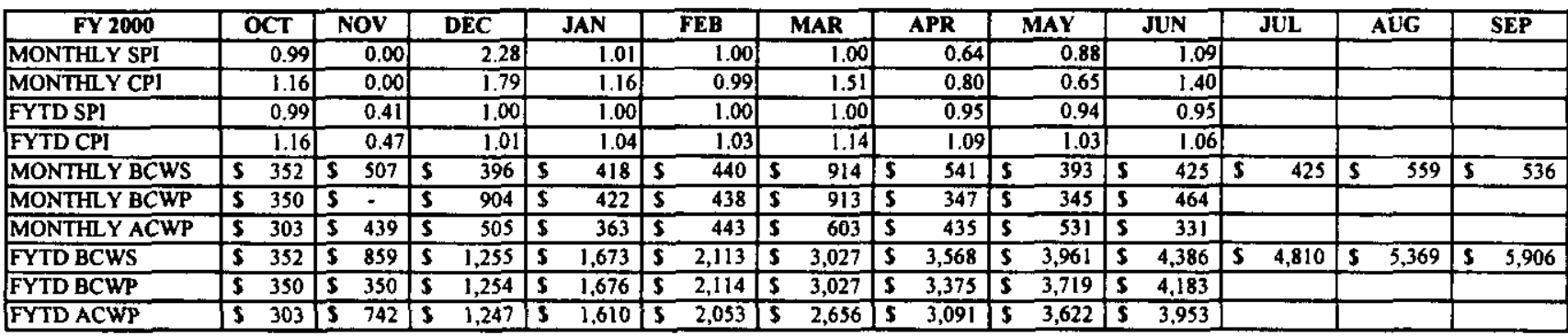

\section{COST VARIANCE ANALYSIS: (\$0.2M)}

\section{WBS/PBS TITLE}

\subsubsection{1/HMO1 HAMMER}

Description and Cause: The variance is within thresholds.

Impact: None

Corrective Action: None

\section{SCHEDULE VARIANCE ANALYSIS: $(-\$ 0.2 \mathrm{M})$}

\section{WBS $\underline{\text { TITLE }}$}

\subsubsection{1/HMO1 HAMMER}

Description and Cause: The variance is within thresholds.

Impact: None.

Corrective Action: None. 


\section{FUNDS MANAGEMENT FUNDS VS SPENDING FORECAST $(\$ 000)$ FY TO DATE THROUGH JUNE 2000 (FLUOR HANFORD, INC. ONLY)}

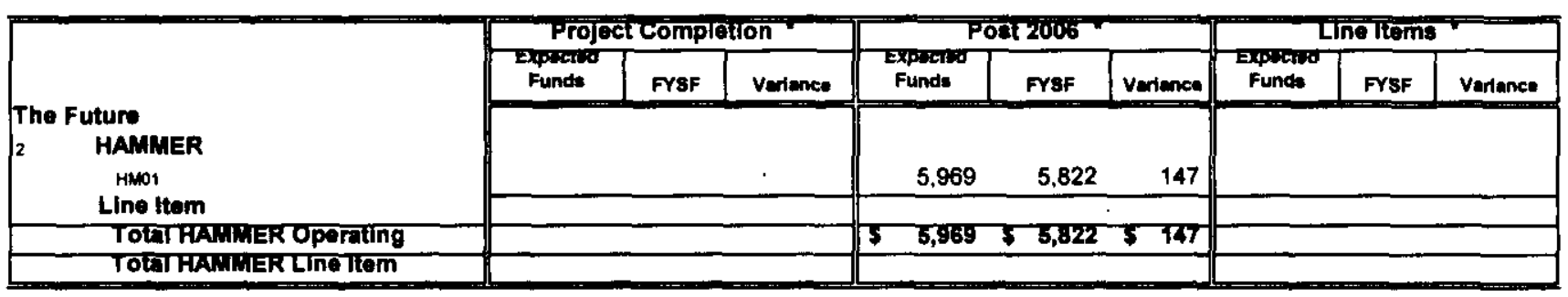

- Control Point

\section{ISSUES}

Nothing to report at this time.

\section{Baseline Chance Requests Currently in Process $(\$ 000)$}

\begin{tabular}{|c|c|c|c|c|c|c|c|c|c|}
\hline $\begin{array}{c}\text { PROJECT } \\
\text { CHANGE } \\
\text { NUMBER }\end{array}$ & $\begin{array}{c}\text { DATE } \\
\text { ORIGIN. }\end{array}$ & \multicolumn{1}{|c|}{$\begin{array}{c}\text { FY00 } \\
\text { COST } \\
\text { MPACT } \\
\text { S000 TITLE }\end{array}$} & SCH & TECH & $\begin{array}{c}\text { DATE } \\
\text { TO CCB }\end{array}$ & $\begin{array}{c}\text { CCB } \\
\text { APR'VD }\end{array}$ & $\begin{array}{c}\text { RL. } \\
\text { APR'VD }\end{array}$ & $\begin{array}{c}\text { CURRENT } \\
\text { STATUS }\end{array}$ \\
\hline HMR-2000-002 & $4 / 12 / 00$ & Adjust FY 2000 MYWP Baseline & $(\$ 300)$ & $\mathrm{N}$ & $\mathrm{Y}$ & $4 / 24 / 00$ & $5 / 12 / 00$ & N/A & Approved \\
\hline
\end{tabular}

\section{MILESTONE ACHIEVEMENT}

\begin{tabular}{|c|c|c|c|c|c|c|c|c|}
\hline \multirow[b]{2}{*}{ MILESTONE TYPE } & \multicolumn{4}{|c|}{ FISCAL YEAR-TO-DATE } & \multicolumn{3}{|c|}{ REMAINING SCHEDULED } & \multirow[b]{2}{*}{$\begin{array}{l}\text { TOTAL } \\
\text { FY } 2000\end{array}$} \\
\hline & $\begin{array}{c}\text { Completed } \\
\text { Early }\end{array}$ & $\begin{array}{c}\text { Completed } \\
\text { On Schedule }\end{array}$ & $\begin{array}{c}\text { Completed } \\
\text { Late }\end{array}$ & Overdue & $\begin{array}{l}\text { Forecast } \\
\text { Early }\end{array}$ & $\begin{array}{c}\text { Forecast On } \\
\text { Schedule }\end{array}$ & $\begin{array}{l}\text { Forecast } \\
\text { Late }\end{array}$ & \\
\hline Enforceable Agreement & 0 & 0 & 0 & 0 & 0 & 0) & 0 & 0 \\
\hline DOE-HQ & 0 & 0 & 0 & 0 & 0 & 0 & 0 & 0 \\
\hline $\mathrm{RL}$ & 0 & 0 & 1) & 0 & 0 & 4 & 0 & 5 \\
\hline Total Project & 0 & 0 & 1 & 0 & 0 & 4. & 0 & 5 \\
\hline
\end{tabular}


PHMC Environmental Management Performance Repont-August 2000 Section $G$ - HAMMER

Tri-Party Agreement / EA Milestones

Nothing to report.

DNFSB Commitments

Nothing to report.

MILESTONE EXCEPTION REPORT

Number/WBS Level Milestone Title

Baseline

Forecast

Date

Date

Overdue - 0

Forecast LATE - 0 


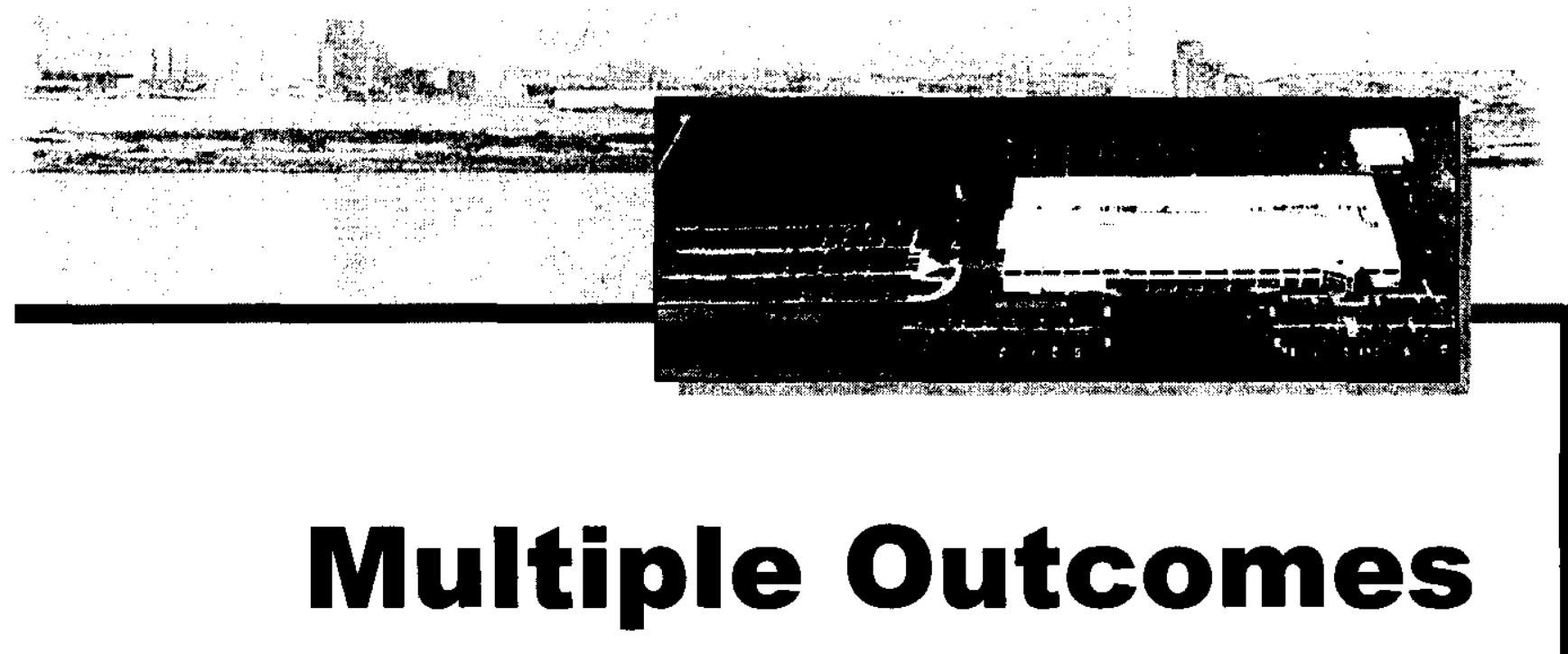

Projects that bridge more than one outcome are included here. These projects include Landlord, Support, and National Programs. Further descriptions are included in each section. 


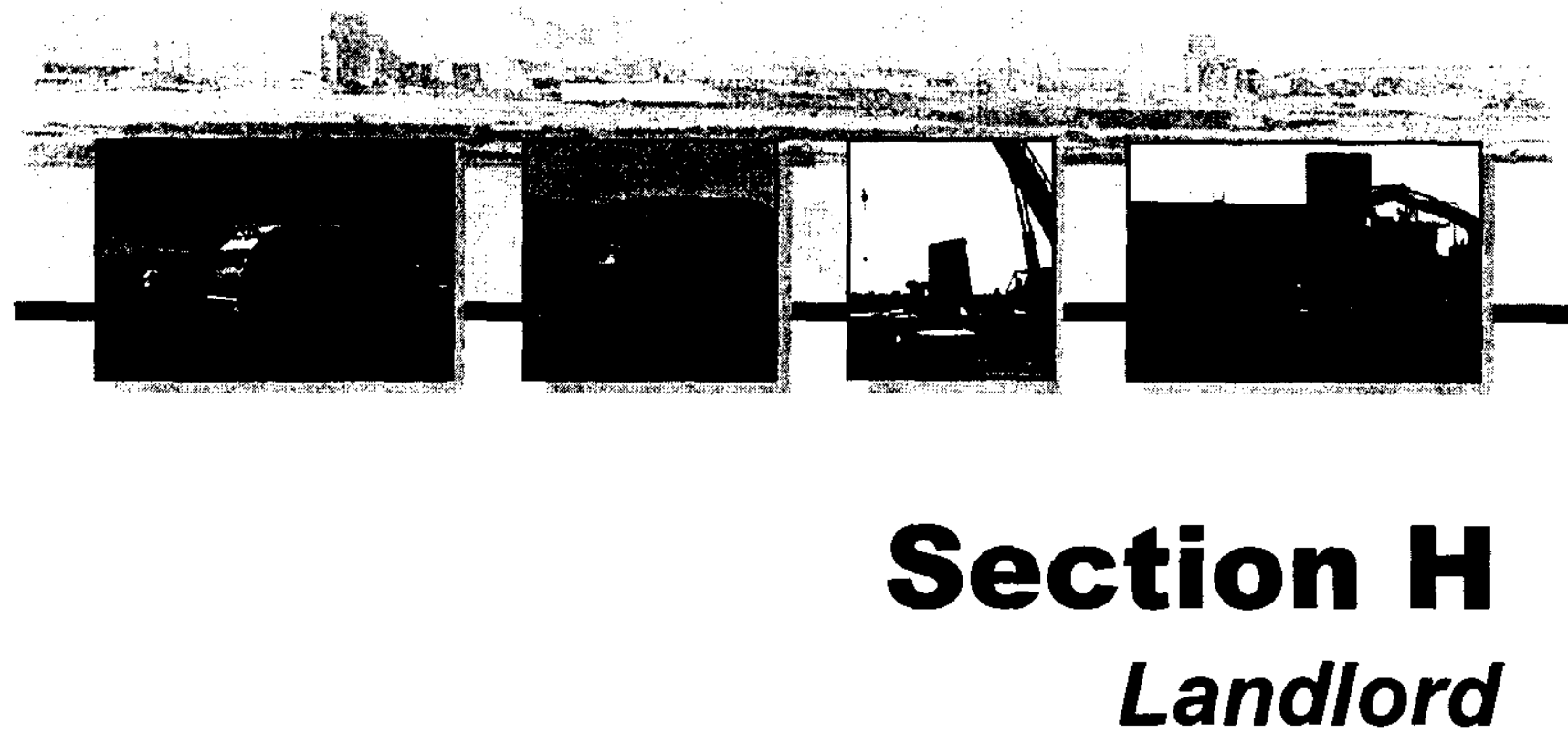

PROJECT MANAGERS S.H. Wisness, RL (509) 373-9337

D.S. Kelly, FH (509) 376-7334 


\section{SUMMARY}
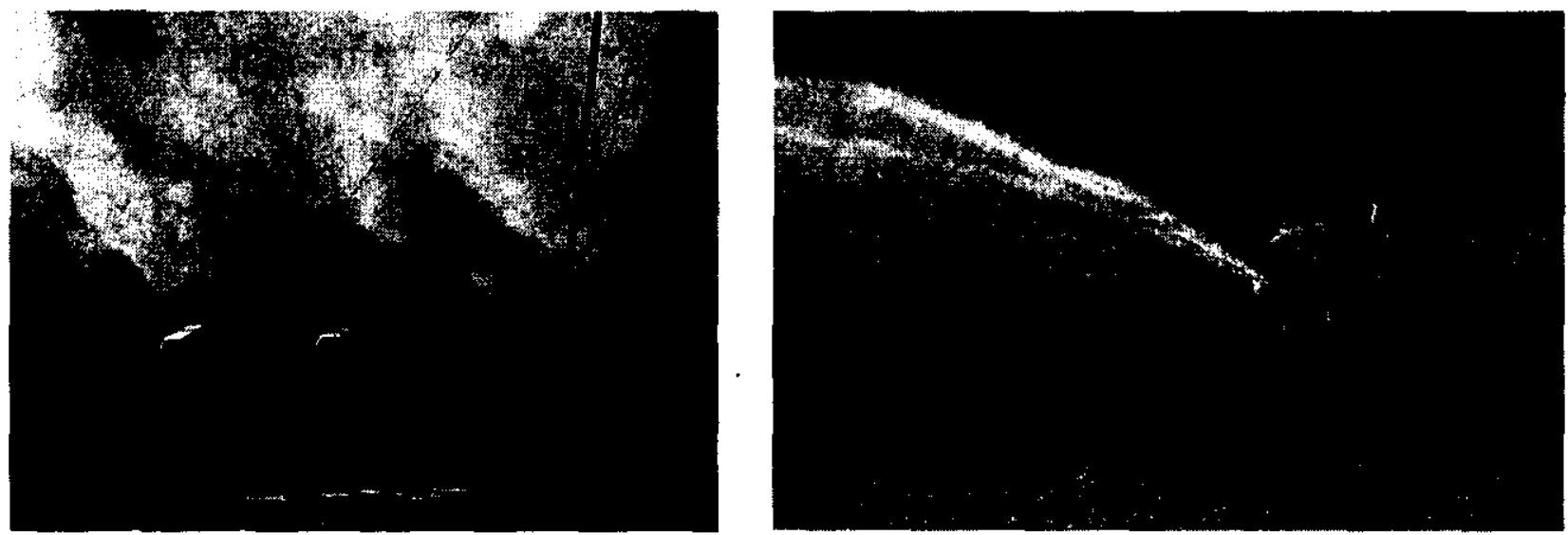

The Landlord mission area consists of the Landlord Project, WBS 1.5.1, Project Baseline Summary (PBS) RL-TP13.

NOTE: Unless otherwise noted, the Safety, Conduct of Operations, Milestone Achievement, and Cost/Schedule data contained herein is as of June 30, 2000. All other information is as of July $26,2000$.

Equipment Dispositioning Project activities include the disposition of one Well Car and one Flat Car in addition to surveillance and maintenance of the $212 \mathrm{R}$ rail siding where the majority of the regulated legacy rail cars are staged for future disposition. A well car was prepared for offsite transport, loaded on a transport truck at the 212R Rail Siding on July 12, 2000 and is in transit to a vendor in Tennessee for the DOE Shield Block Program. The Well Car disposition is approximately two months ahead of the scheduled completion (RL Milestone LLP-00-450). The disposition of up to six regulated flat cars (three Burlington Northern and three PX Cars) are being prepared for transfer to Tri-Cities Asset Reinvestment Company (TARC) to be reused by outside agencies. The work on the removal of the decking on one of the BN Flat Cars has completed and surveys are ongoing to allow "free release" of this car. Due to the suspension on metal recycling mandated by DOE-HQ, excessing of the cleaned Flat Car may not be feasible at this time. Also, due to contamination on the remaining two BN Flat Cars and the three PX Cars, only one flat car may be transferred to TARC in FY 2000 to stay within the authorized funding for this activity. The disposition of the one flat car will be completed as scheduled by September 29,2000 (RL/FH PI).

Four abandoned septic systems have been closed and a final acceptance walk down is being scheduled for early August 2000. Overall, this activity is one month ahead of schedule and within budget to complete RL Milestone LLP-00-460, "Complete Closure of Four Abandoned Septic Systems by August 25, 2000."

Project L-312, "2101M, MO-235, and Associated Buildings Storm Drainage Resolution" resolves storm drainage problems around facilities in 200 East and West Areas. This project involves the installation of catch basins, dry wells, grading, and paving around various 200 Area facilities to properly drain storm water away from these facilities. Field construction effort 
started at the two sites in 200 West on May 24, 2000 and the work at these two sites will be complete by July 27, 2000. Work on the four sites in 200 East Area was initiated on June 8, 2000 and completed on July 6, 2000. The completion of construction is approximately one week ahead of the scheduled date of August 4, 2000 (RL Milestone LLP-00-435).

The annual update of the Multi-Year Work Plan (MYWP) has been initiated to support the completion of RL Milestone LLP-00-401, "Complete Bridge BCR in Support of MYWP Update by August 25, 2000." In addition, the Landlord Project is supporting the Indirect Budget to the Direct Budget conversion for FY 2002 and all deliverables for this effort due by July 14, 2000 were completed on time.

Fiscal-year-to-date milestone performance (EA, DOE-HQ, Field Office, and RL) shows two milestones (100 percent) have been completed ahead of schedule.

\section{ACCOMPLISHMENTS}

Completed RL Milestone LLP-00-405, "Bunker Tank Removal Preparation" fourteen weeks ahead of the scheduled due date of September 29, 2000. This milestone completed activities to prepare the 384 Powerhouse Bunker Tanks for removal in FY 2001. This included removal of the 366-A Building, relocation of a fire hydrant, cleaning out a french drain, and taking other preliminary steps to prepare for tank removal and management of contaminated soil.

\section{SAFETY}

FY 1999 performance was stable for case rates, but was very unstable in terms of severity (days away and restricted). FY 2000 is stable. 

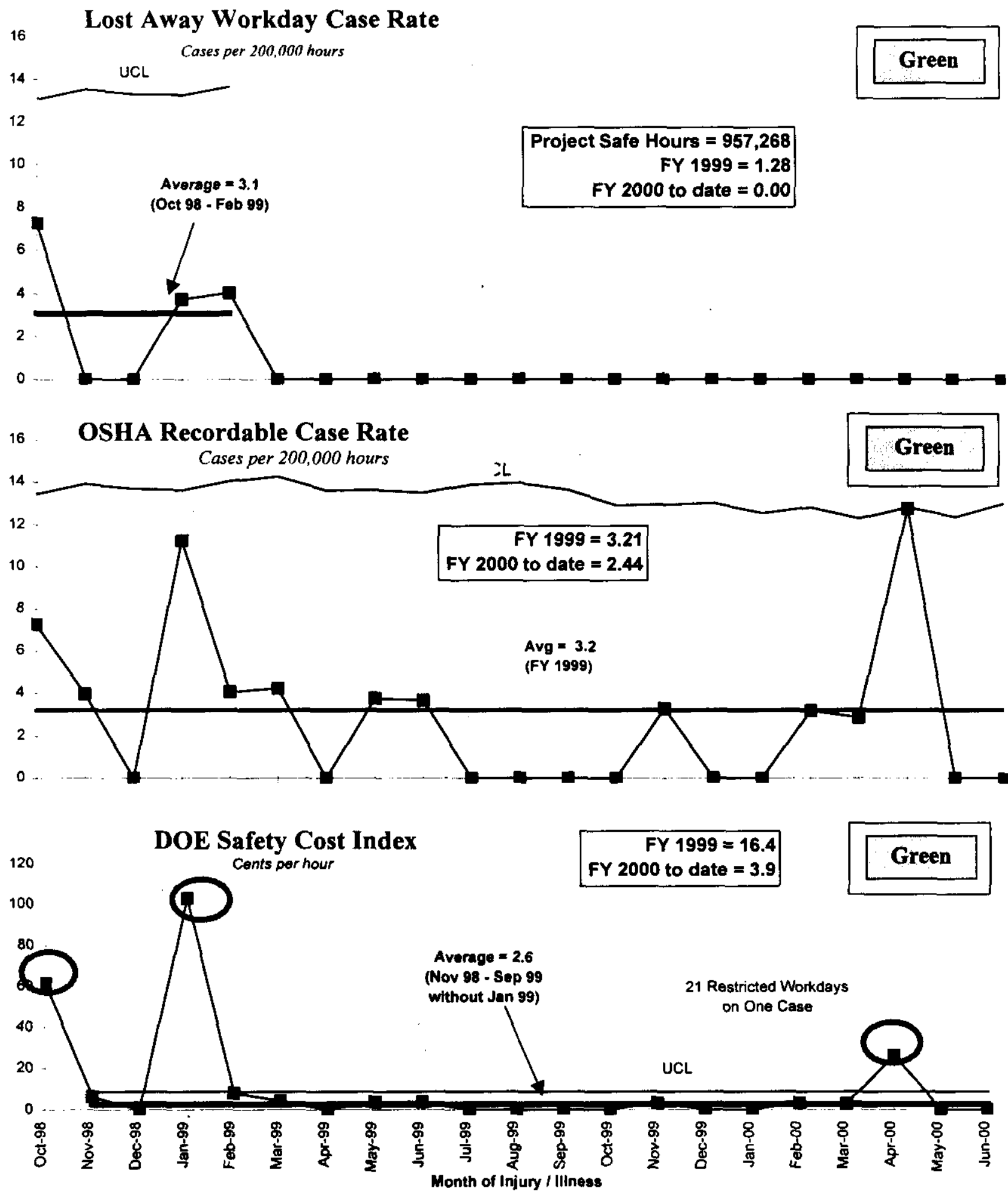


\section{ISMS STATUS}

Green

NOTE: The Infrastructure program includes the Landlord Project and the indirect Infrastructure. Both of these areas are covered under one ISMS program, therefore the ISMS activities described below are for the entire Infrastructure program, which includes Landlord.

- Voluntary Protection Program (VPP) application for status has been submitted to DOE and the evaluation is scheduled for the week of September 14, 2000.

\section{BREAKTHROUGHS / OPPORTUNITIES FOR IMPROVEMENT}

\section{Breakthroughs}

- Nothing to report at this time.

\section{Opportunities for Improvement}

- Nothing to report at this time.

\section{UPCOMING ACTIVITIES}

- $\quad$ Complete Project L-312, "2101M, MO-235, and Associated Buildings Storm Drainage Resolution". Completion of construction is currently one week ahead of the scheduled completion date of August 4, 2000 (RL Milestone LLP-00-435).

\section{Cost Performance (\$M):}

\begin{tabular}{|l|c|c|c|}
\hline & BCWP & ACWP & VARIANCE \\
\hline Landlord & $\$ 8.0 \mathrm{M}$ & $\$ 6.0 \mathrm{M}$ & $\$ 2.0 \mathrm{M}$ \\
\hline
\end{tabular}

The $\$ 2.0 \mathrm{M}$ (26 percent) favorable cost variance is mainly attributed to the auction of six cranes for which a credit was received. Further information at the PBS level can be found in the following Cost Variance Analysis details.

\section{Schedule Performance (\$M):}

\begin{tabular}{|l|l|l|c|}
\hline & BCWP & BCWS & VARIANCE \\
\hline Landlord & $\$ 8.0 \mathrm{M}$ & $\$ 8.8 \mathrm{M}$ & $-\$ 0.8 \mathrm{M}$ \\
\hline
\end{tabular}

The $\$ 0.8 \mathrm{M}$ (9 percent) unfavorable schedule variance is mainly attributed to Project L-297, 
Equipment Dispositioning Project, which is behind schedule due to a strategy change for dispositioning flat cars in achieving free release. The discovery of potential contamination of the lead shielding in the cask car was found resulting in a schedule delay.

\section{FY 2000 Cost/Schedule Performance - All Fund Types Cumulative to Date Status - $(\$ 000)$}

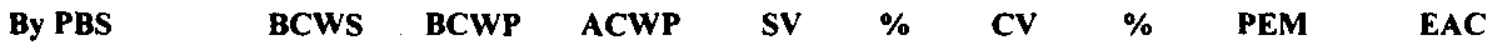

$\begin{array}{llllllllllllllllll}\text { PBS TP13 Landlord } & \$ & 8,820 & \$ & 8,046 & \$ & 5,957 & \$ & (773) & -9 \% & \$ & 2,090 & 26 \% & \$ & 13,978 & \$ & 13,956\end{array}$

WBS 1.5 .1

Total

$\begin{array}{llllllllllllllll}\$ & 8,820 & \$ & 8,046 & \$ & 5,957 & \$ & (773) & -9 \% & \$ & 2,090 & 26 \% & \$ & 13,978 & \$ & 13,956\end{array}$

Note: Landlord EAC includes carryover funding of $\$ 2,033$ for committed GPP's.

\section{Cost/SChedule Performance INDices (MONTHLY AND FYTD)}

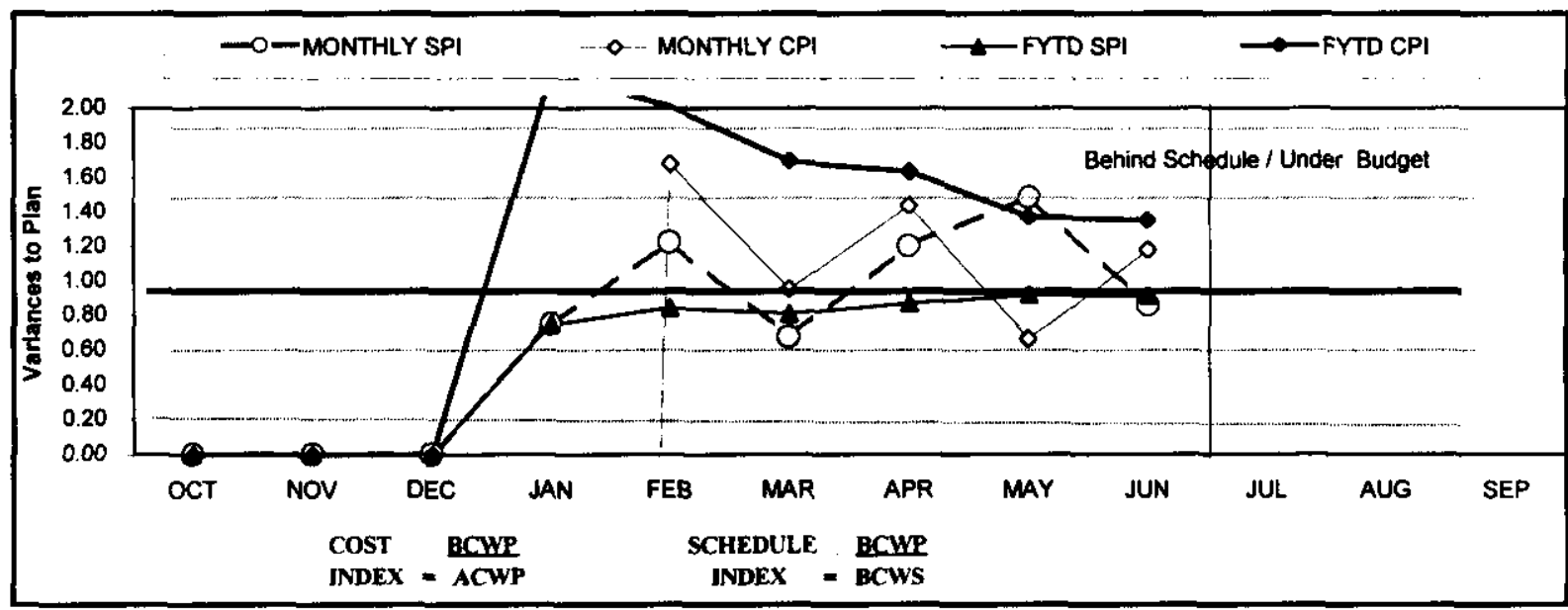

\begin{tabular}{|c|c|c|c|c|c|c|c|c|c|c|c|c|}
\hline FY 2000 & OCT & NOV & DEC & JAN & FEB & MAR & APR & MAY & JUN & JUL & AUG & SEP \\
\hline MONTHLY SPI & 0.00 & 0.00 & 0.00 & 0.75 & 1.22 & 0.67 & 1.20 & 1.48 & 0.86 & & & \\
\hline MONTHLY CPI & 0.00 & 0.00 & 0.00 & -19.23 & 1.68 & 0.95 & 1.43 & 0.66 & 1.18 & & & \\
\hline FYTD SPI & 0.00 & 0.00 & 0.00 & 0.75 & 0.84 & 0.81 & 0.87 & 0.92 & 0.91 & & & \\
\hline FYTD CP! & 0.00 & 0.00 & 0.00 & 2.20 & 2.01 & 1.69 & 1.63 & 1.37 & 1.35 & & & \\
\hline MONTHI.Y BCWS & so & $\$ 0$ & so & $\$ 3.994$ & 51,016 & $\$ 1,269$ & 51,115 & $\$ 653$ & 5773 & 51,407 & $\$ 1,795$ & $\$ 1,956$ \\
\hline MONTHLY BCWP & 50 & so & so & $\$ 2,981$ & 51,243 & $\$ 854$ & $\$ 1,339$ & $\$ 968$ & 5661 & & & \\
\hline MONTHLY ACWP & (\$197) & 5943 & 5767 & (5155) & 5741 & $\$ 899$ & $\$ 934$ & $\$ 1.464$ & $\$ 561$ & & & \\
\hline FYTD BCWS & so & 50 & so & $\$ 3,994$ & 55,010 & $\$ 6,279$ & $\$ 7,394$ & 58,047 & $\$ 8,820$ & $\$ 10,227$ & $\mathbf{S 1 2 , 0 2 2}$ & $\mathbf{S 1 3 , 9 7 8}$ \\
\hline FYTD BCWP & so & So & so & $\$ 2,981$ & $\$ 4,224$ & $\$ 5,078$ & $\$ 6,417$ & $\$ 7,385$ & 58,046 & & & \\
\hline FYTD ACWP & (\$197) & $\$ 746$ & 51,513 & $\$ 1,358$ & $\$ 2,099$ & $\$ 2,998$ & $\$ 3,932$ & 55,395 & $\$ 5,957$ & & & \\
\hline
\end{tabular}

Note: Contains RL-TP13 


\section{Cost VARIance Analysis: $(+\$ 2.0 \mathrm{M})$}

\section{WBS/PBS}

1.5.1/TP-13

Title

in of six cranes in which a credit was received. Procurement of one new crane will be received next year (long lead procurement). In addition, the Municipal Planning Process and the Infrastructure Master Plan are under-running because of a change in resources. Efforts to hire a subcontractor in lieu of using internal labor to complete the Master Plan are underway.

Demolition cost for building 609C for Project L-270, Emergency Services Renovation was not as high as planned. Workscope for this project is being completed on a fixed price contract and construction cost will be higher than planned, reducing the cost variance. Also, Project L-297, "Equipment Dispositioning Project" performance (BCWP) includes completion of activities for flat cars scheduled beyond FY 2000 creating a cost variance.

Impact: No impact to overall project and/or final cost.

Corrective Action: A requisition has been entered into Passport to procure the new crane, which replaces the six sold at auction. A BCR is in process that defers workscope and also reprograms line item funding on completed projects.

\section{SCHEDUle VARIANCE ANALYSIS: (-\$ 0.8M)}

\section{$\underline{\text { WBS/PBS }}$}

1.5.1/ TP13

Description /Cause: The $\$ 0.8 \mathrm{M}$ (9 percent) unfavorable schedule variance mainly attributed to Project L-297, Equipment Disposition Project, which is behind schedule due to a strategy change for dispositioning flat cars in achieving free release and the discovery of potential contamination of the lead shielding in the casks car was found resulting in a schedule delay. Construction to install a new system to replace chlorinating system at the 200 West Area Water Treatment Plant was originally planned as a fixed price contract. A Plant Forces Work Review deemed the work to be plant forces, resulting in a schedule variance. Definitive Design has been completed and procurement contracts started for materials.

Impact: No impact to overall project schedule.

Corrective Action: None. 


\section{FUNDS MANACEMENT FUNDS US SPENDING FORECAST ( $\$ 000)$ FY TO DATE THROUGH JUNE 2000 (FLUOR HANFORD, INC. ONLY)}

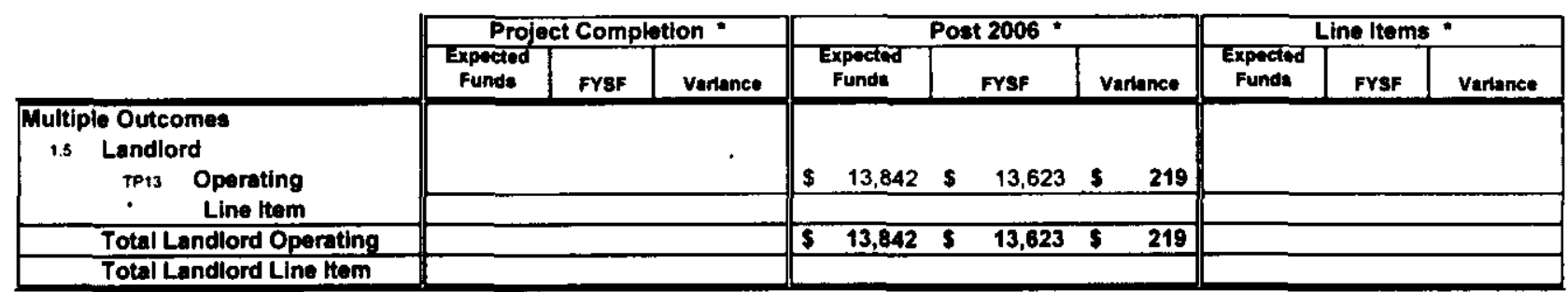

- Control Point

\section{ISSUES}

Fire Impacts to the Integrated Soil, Vegetation, and Animal Control Program Impact (s): As a result of the recent Site fire, there will be a need for re-vegetation, soil stabilization and other measures that were not planned this fiscal year. Corrective Action: A detailed cost estimate and recommendations are being prepared which will identify the corrective action for this issue.

\section{Baseline Change Requests Currently in Process (\$000)}

\begin{tabular}{|c|c|c|c|c|c|c|c|c|c|}
\hline $\begin{array}{c}\text { PROJECT } \\
\text { CHANGE NUMBER }\end{array}$ & $\begin{array}{c}\text { DATE } \\
\text { ORIGIN. }\end{array}$ & BCR TITLE & $\begin{array}{c}\text { FYOO COST } \\
\text { IMPACT } \\
\text { SO00 }\end{array}$ & SCH & ТЕСН & $\begin{array}{c}\text { DATE TO } \\
\text { CCB }\end{array}$ & $\begin{array}{c}\text { CCB } \\
\text { APR'VD } \\
\end{array}$ & $\begin{array}{c}\text { RL } \\
\text { APR'VD } \\
\end{array}$ & $\begin{array}{l}\text { CURRENT } \\
\text { STATUS } \\
\end{array}$ \\
\hline LPM-00-001 & $11 / 3 / 99$ & $\begin{array}{l}\text { MYWP Baseline Modification } \\
\text { (Bridge BCR FY00, 01, 02) }\end{array}$ & $\$ 4,642$ & $\bar{X}$ & $\mathrm{X}$ & $1 / 11 / 00$ & $1 / 14 / 00$ & $1 / 27 / 00$ & $\begin{array}{l}\text { Approved by } \\
\text { RL }\end{array}$ \\
\hline LPM=00-003 & $12 / 8 / 99$ & Document FY99 Carryover Funds & $\$ 1,793$ & & $\mathrm{X}$ & $12 / 13 / 00$ & $1 / 3 / 00$ & $1 / 3 / 00$ & $\begin{array}{l}\text { Approved by } \\
\mathrm{RL}\end{array}$ \\
\hline LPM-00-005 & $3 / 23 / 00$ & $\begin{array}{l}\text { Document Rate Increase, Funding } \\
\text { Reductions, and Impacts to } \\
\text { Milestones }\end{array}$ & $\$<318>$ & $\mathrm{X}$ & $\mathrm{X}$ & $4 / 13 / 00$ & $4 / 27 / 00$ & $5 / 25 / 00$ & $\begin{array}{l}\text { Approved by } \\
R L\end{array}$ \\
\hline LPM-00-006 & $5 / 30 / 00$ & $\begin{array}{l}\text { Added Scope for } 1163 \text { Re-roof, } \\
\text { Defere Definitive Design for L- } \\
\text { 327, Delete Milestone LLP-00-465 }\end{array}$ & $\$ 180$ & $\mathrm{X}$ & $X$ & $6 / 8 / 00$ & $6 / 8 / 00$ & $6 / 26 / 00$ & $\begin{array}{l}\text { Approved by } \\
\mathrm{RL}\end{array}$ \\
\hline \multicolumn{10}{|c|}{ ADVANCE WORK AUTHORIZATIONS } \\
\hline & & N/A & & & & & & & \\
\hline
\end{tabular}


PHMC Environmental Management Performance Report - August 2000

Section H-Landlord

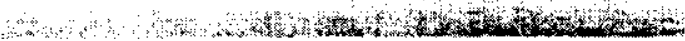

\section{Milestone ACHIEVEMENT}

\begin{tabular}{|r|r|r|r|r|r|r|r|r|}
\hline & \multicolumn{2}{|c|}{ FISCAL YEAR-TO-DATE } & & \multicolumn{2}{c|}{ REMAINING SCHEDULED } & \\
\cline { 2 - 9 } Mi LES TONE TYPE & $\begin{array}{c}\text { Completed } \\
\text { Eary }\end{array}$ & $\begin{array}{c}\text { Completed } \\
\text { On Schedule }\end{array}$ & $\begin{array}{c}\text { Completed } \\
\text { Late }\end{array}$ & Overdue & $\begin{array}{c}\text { Forecast } \\
\text { Early }\end{array}$ & $\begin{array}{c}\text { Forecast } \\
\text { On } \\
\text { Schedule }\end{array}$ & $\begin{array}{c}\text { Forecast } \\
\text { Late }\end{array}$ & $\begin{array}{c}\text { TOTAL } \\
\text { FY 2000 }\end{array}$ \\
\hline Enforceable Agreement & 0 & 0 & 0 & 0 & 0 & 0 & 0 & 0 \\
\hline DOE-HQ & 0 & 0 & 0 & 0 & 0 & 0 & 0 & 0 \\
\hline RL & 2 & 0 & 0 & 0 & 0 & 7 & 0 & 9 \\
\hline Total Project & 2 & 0 & 0 & 0 & 0 & 7 & 0 & 9 \\
\hline
\end{tabular}

Nothing to report.

Tri-Party Agreement / EA Milestones

Nothing to report. DNFSB Commitments

\section{MILESTONE EXCEPTION REPORT}

Number/WBS Level Milestone Title

Baseline Forecast

Numberrwas Level

Date

Date

\section{OVerdue - 0}

FORECAST LATE - 0 


\section{Performance Objectives}

The items listed below are not Performance Incentives. They are performance goals (i.e., milestones and goals between $\mathrm{FH}$ and the subcontractor).

\begin{tabular}{|c|c|c|}
\hline Outcome & Performance Goals & Status \\
\hline \multirow{6}{*}{$\begin{array}{l}\text { Restore the River } \\
\text { Corridor for } \\
\text { Multiple Uses } \\
\& \\
\text { Transition the } \\
\text { Central Plateau }\end{array}$} & $\begin{array}{l}\text { Replace I,500 Feet of } 2 \text {-inch } \\
\text { Sanitary Water Line from } \\
\text { 272AW Building Along } \\
\text { Canton Ave. in } 200 \text { East }\end{array}$ & $\begin{array}{l}\text { Expect to award fixed price contract by July } 28,2000 \text { to support } \\
\text { construction completion by September } 29,2000 \text {. }\end{array}$ \\
\hline & $\begin{array}{l}\text { Provide Vegetation and Animal } \\
\text { Control to Reduce/Minimize } \\
\text { the Spread of Contamination }\end{array}$ & $\begin{array}{l}\text { Spraying Soil Surfactant (Soil Sement) on the bumed area in } 200 \\
\text { West from the recent Hanford Site Range fire. Approximately } 10 \\
\text { acres have been covered to date and an additional } 720 \text { acres are } \\
\text { planned. Preparing recommendations and a detailed cost estimate } \\
\text { for dust control. }\end{array}$ \\
\hline & Legacy Site Cleanup & $\begin{array}{l}\text { Cleanup of the Well Drilling Slab Yard in } 200 \text { East is complete. } \\
\text { Two additional Legacy Sites are being cleaned up in FY } 2000 \text { that } \\
\text { are essentially complete with final punchlist items being worked. }\end{array}$ \\
\hline & $\begin{array}{l}\text { Complete Installation of } \\
100 \mathrm{~K} / \mathrm{D} \text { Emergency } \\
\text { Notification Sirens which will } \\
\text { Complete the Total Integration } \\
\text { of All Outside Sirens }\end{array}$ & $\begin{array}{l}\text { Overall the project is } 90 \text { percent complete with all four new sirens } \\
\text { installed to date. System checkout and testing will be complete in } \\
\text { late July. Project closeout is planned for September } 2000 \text {. }\end{array}$ \\
\hline & $\begin{array}{l}\text { Complete Emergency Services } \\
\text { Renovation of the } 200 \text { Area } \\
\text { Fire Station }\end{array}$ & $\begin{array}{l}\text { Demolition of } 609 \mathrm{C} \text { Building for renovation of the living } \\
\text { quarters/dormitory area of the fire station was completed February } \\
24,2000 \text {. Contruction is continuing with installation of the } \\
\text { underground utilities and the building foundation installation. } \\
\text { Erection of the new building will begin in August } 2000 \text { and } \\
\text { supports construction completion as scheduled by April } 6,2001 \text {. }\end{array}$ \\
\hline & $\begin{array}{l}\text { Shutdown Approx. } 20 \text { Vacant } \\
\text { Office Facilities - Deactivate } \\
25 \text { Vacant Facilities }\end{array}$ & $\begin{array}{l}\text { Sixteen of the planned } 20 \text { facilities have been shutdown for the } \\
\text { fiscal year and } 22 \text { of the planned } 25 \text { facilities have been } \\
\text { deactivated. Project remains on schedule. }\end{array}$ \\
\hline $\begin{array}{l}\text { Put Assets to } \\
\text { Work for the } \\
\text { Future }\end{array}$ & $\begin{array}{l}\text { Disposition One Well Car and } \\
\text { One Flat Car - Surveillance } \\
\text { and Maintenance of Legacy } \\
\text { Rail Cars at 212R Awaiting } \\
\text { Disposition }\end{array}$ & $\begin{array}{l}\text { A well car is in transit to a vendor in Tennessee for the DOE } \\
\text { Shielding Block Program. The work on the removal of the decking } \\
\text { on one of the BN Flat Cars has been completed and surveys are } \\
\text { ongoing to allow "free release" of this car. Due to the suspension } \\
\text { on metal recycling mandated by DOE-HQ, excessing of the cleaned } \\
\text { Flat Car may not be feasible at this time. Also, due to } \\
\text { contamination on the remaining two BN Flat Cars and the three PX } \\
\text { Cars, only one flat car may be transferred to TARC in FY } 2000 \text { to } \\
\text { stay within the authorized funding for this activity. }\end{array}$ \\
\hline
\end{tabular}




\section{KEY INTEGRATION ACTIVITIES}

Continue to support RL on the following activities to plan and manage land and resources for the Hanford Site:

- $\quad$ Continue to support RL to establish a Hanford Site Planning Advisory Board made up of cooperating agencies and Tribal representatives to support implementation of the Comprehensive Land Use Plan (CLUP).

- Developing Area and Resource Management Plans (i.e., Landlord Infrastructure Master Plan and Industrial Mineral Resource Management Plan) to support implementation of the CLUP.

- $\quad$ Assisting DOE in identifying mandatory requirements functions, interfaces and relationships for successful long-range planning and management of Site land and resources.

- Coordinating reviews and approvals for the use of land on Site.

- Developing and administering Real Estate documents (e.g., licenses, leases, easements, and permits). 


\section{Building DeActivation}

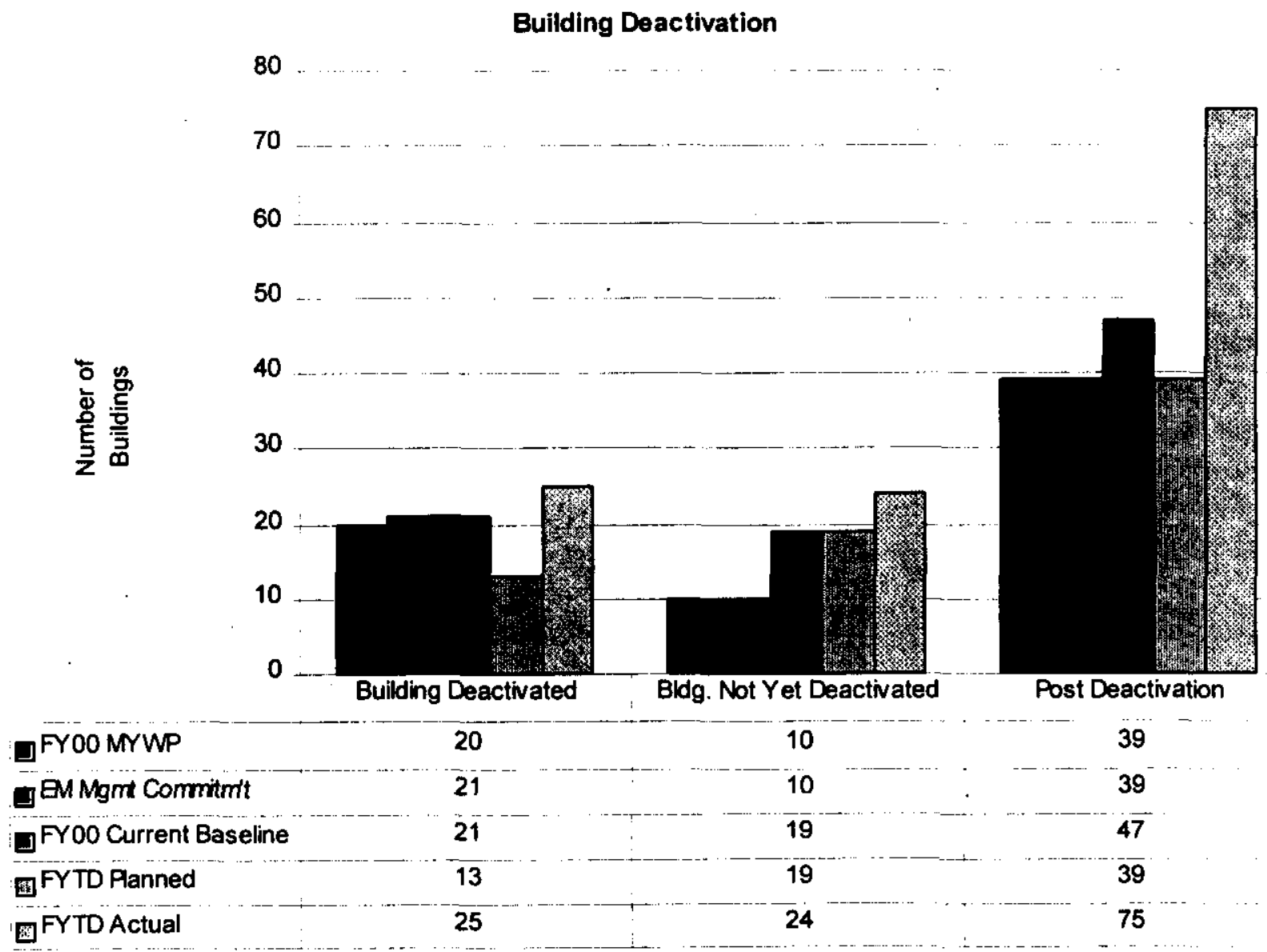

Buildings Deactivated: More buildings were vacated last period than planned and some of those additional buildings were deactivated because the action was simple and relatively inexpensive.

Buildings Not Yet Deactivated: These totals represent a queue with the baseline and planned total being what is expected at the end of the year. This is dependent on actions of other projects and is not within Landlord control. Comparisons from period to period are not meaningful.

Post Deactivation Monitoring: More buildings were vacated this period than planned and were deactivated and are now in post deactivation. Nine buildings were added to the actual count that were vacated but did not require deactivation. 


\section{FACILITY DECOMMISSIONING - CLEANUPS}

Facility Decommissioning - Cleanups

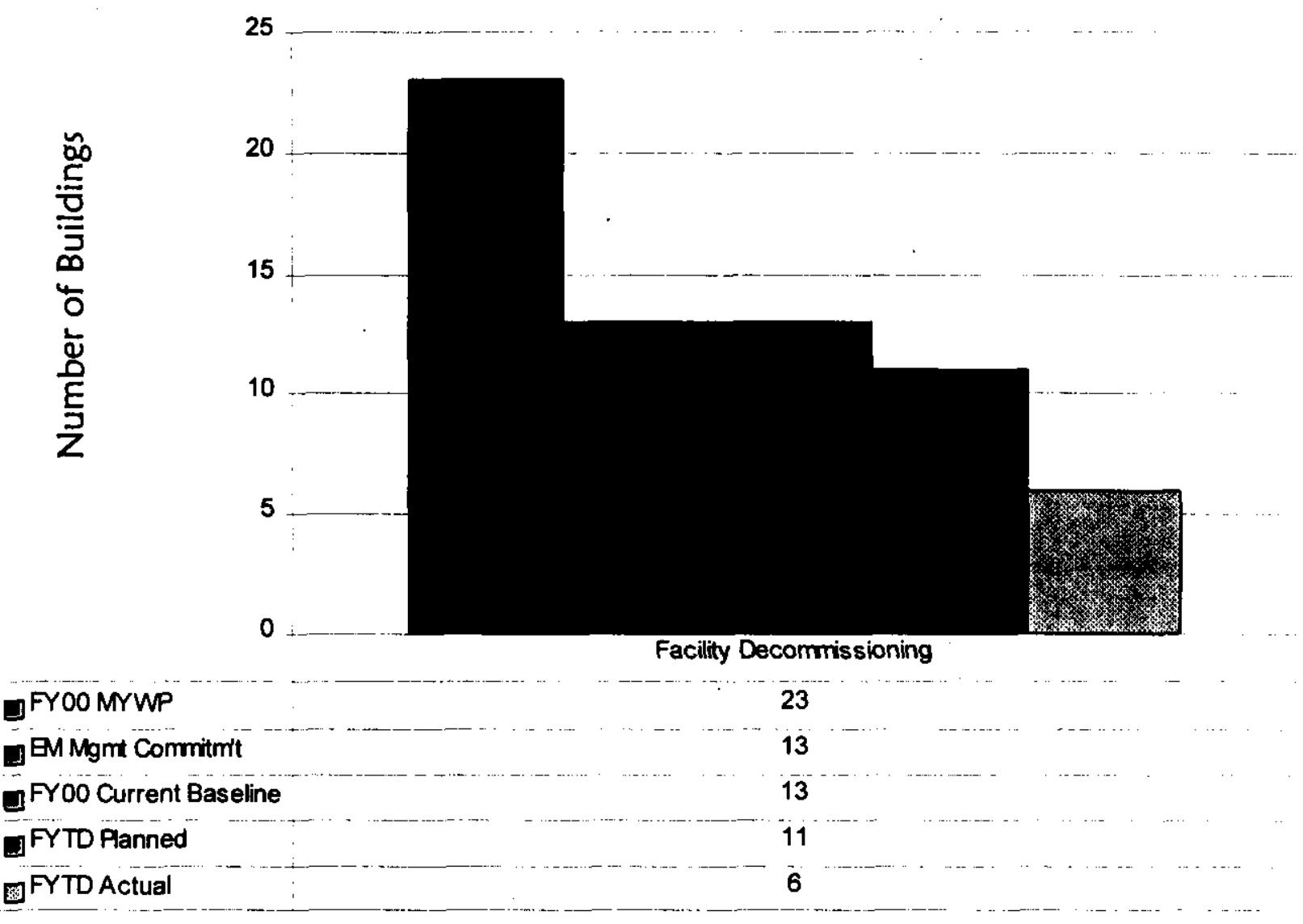

Facility Decommissioning: Several Facilities have been prepared for the July excess property sale and will be counted in the fourth quarter. The landlord project expects to meet or beat its baseline decommissioning target for FY 2000 . 


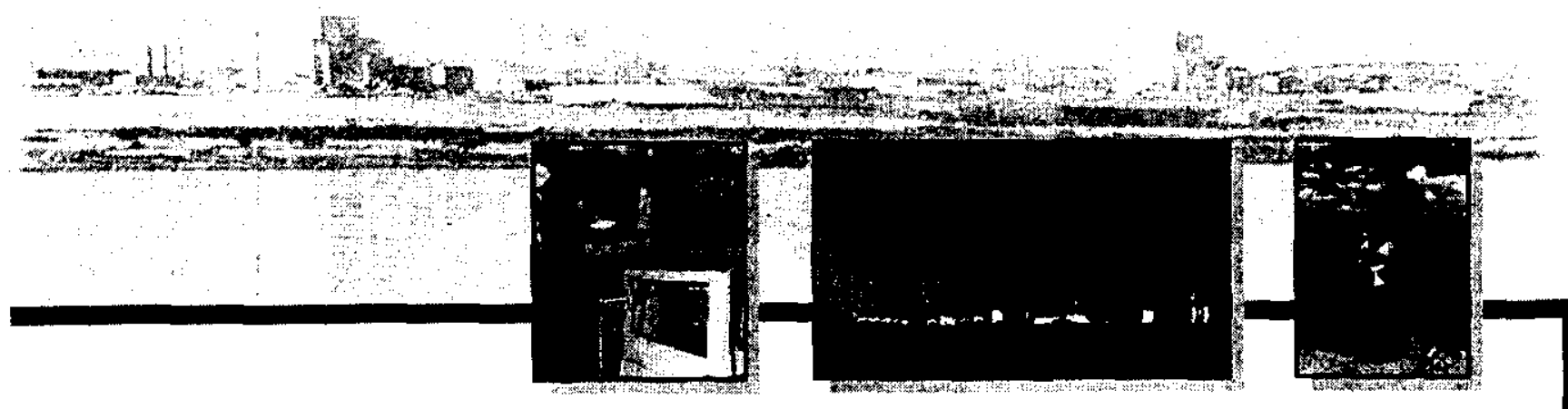

\section{Section I Support}

PROJECT MANAGERS

SP\&I W.W. Ballard, RL

(509) 376-6657

G.J. McCleary, FH

(509) $372-8385$

SSE W.W. Ballard, RL

(509) 376-6657

M.L. Grygiel, FH

(509) $372-2983$

ECP S.H. Wisness, RL

(509) 373-9337

J.W. Hales, FH

(509) $376-4069$

PSRP S.H. Wisness, RL

(509) 373-9337

R.L. Dirkes, PNNL

(509) $376-8177$ 


\section{SUMMARY}

Mission Support, Project Baseline Summary (PBS) OT01, consists of four sub-projects:

- Planning and Integration [Work Breakdown]

- $\quad$ Structure (WBS 1.8.2.1)]

- $\quad$ Systems Engineering (WBS 1.8.2.2)

- $\quad$ Environmental Compliance (WBS 1.8.2.3)

The Environmental Compliance Program is composed of two elements. These two elements were stand-alone programs known as the Hanford Environmental Management Program (HEMP) and the Effluent and Environmental Monitoring Program (EEM) prior to FY99. Although there is a single program, these elements retain their identity on the Integrated Priority List as two separate Units of Analysis.

- $\quad$ Public Safety and Resource Protection (WBS 1.8.2.4)

In addition, Richland Directed Activities, PBS OT04, is included in this section. It consists of general site requirements such as:

- Resource Conservation and Recovery Act [RCRA] Mixed Waste Fee (management fee)

- Department of Health (DOH) Oversight (air monitoring)

- Downwinder Litigation

- $\quad$ Permits/site support [State of Washington (air emissions program)]

- $\quad$ Emergency Preparedness Grants

- State of Oregon Hanford Oversight

- Payment in Lieu of Taxes

- Hanford Advisory Board/Miscellaneous Grants (Hanford Openness Panel)

- Uranium Mass Balance Project (Paducah)

- National Security Analysis (formerly declassification of documents)

- Other minor financial assistance grants and contracts.

NOTE: Unless otherwise noted, the Safety, Conduct of Operations, Milestone Achievement, and Cost/Schedule data contained herein is as of June 30, 2000. All other information is as of July 3, 2000 unless otherwise noted.

Fiscal-year-to-date milestone performance (EA, DOE-HQ, and RL) shows that 31 of 34 milestones ( 92 percent) were completed on or ahead of schedule and three milestones (eight percent) were completed late. The Milestone Achievement details, found following cost and schedule variance analysis, provide further information on all milestone types. 


\section{Site Planning and Integration (SP\&I)}

Multi Year Work Plan (MYWP) Kickoff Held - Site Planning and Integration (SP\&I) held the Kickoff meeting for Fluor Hanford (FH) projects on June 13, 2000. The first deliverable will be the Phase I initial MYWP on July 28, 2000.

Resource Loaded Summary Schedule - Following delivery of the RL Summary Schedule on May 11, 2000, meetings have been held with the Mission Planning Division (MPD) to discuss the update cycle and associated products required for the Annual Work Plan (AWP) update. The next task, planned for early July, is to utilize the RL Summary Schedule with the Schedule Options Team on work-scope change scenarios.

Indirect to Direct Conversion - FH received formal direction to proceed with the Indirect to Direct conversion. This effort will be combined with the decision to use a new Work Breakdown Structure (WBS) for the site. This structure will be developed to support the initiative to structure by Outcomes (i.e. River Corridor, Central Plateau, and Multi Outcome) for FY 2002. The MPD has assembled a team to develop options to this new structure, with representatives from both SP\&I and Systems Engineering included.

Budget Lessons Learned - The MPD and SP\&I hosted a lessons-learned session to improve the budget formulation process for the next Budget Update cycle. These sessions provided the $\mathrm{FH}, \mathrm{BHI}$, and PNNL projects the opportunity to make recommendations to improve areas of concern. The MPD and SP\&I together developed an action plan and associated schedule to follow-up on commitments made as a result of the session. This schedule will be statused and updated on the SP\&I Tuesday Weekly Budget Conference Call.

Integrated Priority List (IPL) Activities - The Integrated Priority List (IPL) module continues to be upgraded to provide additional functionality for the users and owners of the system. Modifications are targeted to produce additional report and sort capabilities, and align the system to better support the development of the FY 2003 budget request.

Funds Management - SP\&I continued to obtain Fiscal Year Spend Forecast (FYSF) and Estimate at Completion (EAC) data from FH Projects. This information is used to analyze the projected spending for the PHMC in comparison to available funds and to evaluate project performance. Over \$14M in unfunded Stretch and Super Stretch work scope has been authorized to date, and recent trends indicate that without action, costs will exceed funds. Management has taken aggressive actions designed to correct this situation. In addition, an internal reprogramming package was submitted to DOE-RL, which transfers $\$ 5 \mathrm{M}$ from the Post 2006 control point to the Project Completion control point. This transfer helps to balance the cost problem between the control points, but will not totally resolve the overall funds management issues. SP\&I will be monitoring costs very closely, and with increased frequency, to insure that the management actions yield the necessary results.

Performance Management Meetings - Two of the three Performance Management Meetings scheduled for June ("The River," "The Central Plateau," and "PHMC Services and Support/Comprehensive Performance Incentives") were held. The monthly "Central Plateau" 
meeting, scheduled for June 29, 2000, was cancelled due to schedule conflicts. Data materials for all briefings were prepared and distributed to the attendees as planned. Information Resource Management work scope was addressed for the first time in the quarterly "PHMC Services and Support" meeting which was held on June 6, 2000. The inclusion of this work scope will be continued in upcoming "PHMC Services and Support" meetings, to provide RL a more complete picture of the indirect work performed and managed by $\mathrm{FH}$ at Hanford.

Business Management Oversight Process (BMOP) Status - SP\&I is in the process of collecting documentation that addresses and demonstrates fulfillment of the BMOP criteria. The area of Classification/Declassification, Safeguards and Security and Training are still being evaluated to determine the BMOP criteria.

\section{SYSTEMS ENGINEERING AND INTEGRATION (SE\&I)}

Technical Baseline Products - SE\&I released four Hanford Site Technical Database (HSTD) baselines during the third quarter. The new baseline maintains a 99.5 percent data quality.

SE\&I supported the Schedule Options Study by providing technical baseline information and performing various alternative analyses. The technical data will be utilized in the RL Outcome Plan.

SE\&I and Management Systems supported the FH Requirements Initiatives Integration Team. This effort has been divided into two phases. The primary focus during Phase I is to find $\$ 30 \mathrm{M}$ in base operations efficiencies to offset key cleanup work in FY 2001 and FY 2002. Phase II will focus on the long-term requirement management and control efforts.

SE\&I is participating on the DOE-RL team developing a revised WBS/PBS for the RL EM mission. The recommended PBS structure will be presented to $\mathrm{RL}$ and contractor senior management during the second week in July.

Management Systems - The Configuration Management (CM) Plan, the CM Requirements Document, and the revised CM Policy have been completed in draft and transmitted to the Project Hanford Management System (PHMS) for the review and comment cycle. These documents are scheduled for publication during August following the issuance of HNF-PRO589.

The first CM discipline leads meeting was held on June 22, 2000. During this meeting, members received draft copies of the CM Plan, the CM Requirements Document, and the CM Policy for their review. These leads are intended to become the technical expert group for CM implementation. These meetings will also become the forums for the Interface Control Working Group (ICWG). 
SE\&I Infrastructure - An HSTD test [System Level Automation Tool for Engineers (SLATE)] database was built with a Functional Hierarchy, Physical Architecture, PBS, and allocation of functions to PBS. An RDD to SLATE conversion code for requirements, functions, behavioral items and functions was created.

\section{Environmental Compliance Program (ECP)}

Environmental Services continued coordination and support for preparation of an appeal of the Modification E proposed Permit modifications. The schedule for appeal/no appeal actions once the Permit is issued was updated. The latest information from Ecology indicates that the earliest Modification E could be issued is end of July 2000.

Environmental Compliance Issue Status Write-ups were identified and developed to support the U.S. Department of Energy Richland Operations Office-Office of Site Services (OSS) request. The write-ups will be used to brief upper management on issues that exist between the Permittees and Ecology that have seen little or no movement towards issue resolution.

On Monday July 3, 2000, the Washington State Department of Ecology (Ecology) inspected hazardous waste storage areas, Treatment, Storage, and Disposals (TSDs), and contaminated ponds and ditches that were affected by the recent fire. The main focus was to inspect and photograph the vegetation covering inactive waste disposal sites to determine if it had burned; hence, evaluating whether sampling may be in order.

The Washington State Department of Health (WSDOH) has agreed that the highways and the Columbia River shore shall not be considered as Maximally Exposed Individual (MEI) locations. The letter stating this agreement has not yet been sent, and a discussion with WSDOH will occur on July 18, 2000. Thus far, DOH continues to review and approve Hanford Site Notice of Construction (NOC) (permits) without any delays.

Changes to the Toxic Substances Control Act (TSCA) rules have eliminated the requirement for preparing the Polychlorinated Biphenyl (PCB) Annual Report (Milestone ECP-00-505).

The Hanford Site Air Operating Permit Application Supplement was delivered on June 15, 2000. The supplement was certified by all Hanford prime contractors, and makes the application current to April 2000. Delivery to the State of Washington, Department of Ecology (Ecology) will allow Ecology to reissue the draft Hanford Site Air Operating Permit for public review. Reissue is anticipated in late summer 2000 , with the final permit issued late fall or winter 20002001.

\section{Public Safety and Resource Protection (PSRP)}

RL has verbally approved the change of the Cultural Resource Project milestone and a Baseline Change Request (BCR) (PSR-2000-002) has been submitted for RL review and approval. This change approved the addition of scope within the Ecosystem Monitoring, Surface Environmental Surveillance, Hanford Environmental Oversight and Ecological Compliance Assessment Projects. This BCR also approved the revision of an RL milestone within the Cultural Resources 
Project. No additional funds were requested to complete additional work scope. Funding $(\$ 175 \mathrm{~K})$ realized as a result of LDRD reduction from program overheads, was on hold pending a $\mathrm{RL}$ decision on potential reallocation. $\mathrm{RL}$ determined that available funding from the LDRD reduction should remain within the Program to address funding shortfalls. The revised baseline is $\$ 6,125 \mathrm{~K}$.

\section{ACCOMPLISHMENTS}

The near facility ambient air sampling stations were checked for any detectable increased radioactivity due to the wild fire burning over the site. The onsite network of near facility air samplers surrounds the major operating areas at Hanford, including over twenty specific facilities and projects. All of the 80 air sample stations that comprise the onsite near facility monitoring network survived the fire and remained operational, thus meeting all permit conditions. Sample filters were exchanged at each air sample station and submitted for laboratory analysis. The sampling effort confirmed that no significant increase in radioactivity (alpha and beta) occurred due to the Hanford range fire. Total Alpha results across the site were very slightly elevated; however, the results were not significantly different from sampling results from the prior 12month period. Additional isotopic sampling is scheduled and the sampling results will be normalized. Geographical composites are being analyzed for specific isotopes of $\mathrm{Pu}, \mathrm{U}$, and $\mathrm{Sr}$, and total gamma. Each group consists of nine or ten filters. The sample filters, taken immediately after the fire and the next set collected ten days following the fire, will be analyzed separately at the request of DOE. All laboratory results should be available in three to four weeks.

\section{Site Planning and Integration (SP\&l)}

- $\quad$ The deliverable, Resolution of Suggested Changes to BUG, was completed on June 20, 2000.

- The deliverable, Prepare Reconciliation Current Year PBS/MYWP to Path to Closure for the Annual EM Liability Summary, was completed on June 30, 2000.

- $\quad$ The deliverable, Monthly EMPR, was delivered on June 6, 2000.

\section{System Engineering and Integration (SEI)}

- $\quad$ Nothing to report.

\section{Environmental Compliance Program (ECP)}

\section{RCRA Permit Revision and Implementation}

Environmental Services coordinated the monthly Resource Conservation and Recovery Act (RCRA) Permit Steering Committee meeting and issued meeting minutes. At the meeting proposed Training Chapters (Chapter eight) were provided to Ecology. Ecology informed DOE and the Contractors that it would not review/approve the proposed modifications to the Chapter eight (222-S Laboratory Complex) until the public comment period has been completed. 
The RCRA Permit Class one modifications package for the quarter ending July 10, 2000 was coordinated sitewide and submitted to DOE for concurrence June 26, 2000, and supported transmittal to Ecology by July 10, 2000 .

The electronic Part A, Form three file was updated to reflect the 7/97 Ecology form. Ecology has requested the Permittees to use the 7/97 form.

Revisions to the PUREX Storage Tunnel Dangerous Waste Training Plan (DWTP) and 200 Area Liquid Waste Processing Facility DWTP to support site-wide upgrades were prepared based on permitting workshops on the 222-S Laboratory Part B Permit Application.

\section{Air Compliance}

Management and integration support was provided in billing verification and tracking asbestos Notice of Intent (NOI) approvals and transferring additional Calendar Year (CY) 2000 funds to the NOI account for Benton Clean Air Authority payment authorization.

Coordination was provided in Ecology's Air technical assistance program, which kicks off in July 2000 and runs through June 2001.

\section{Inspections/Assessments}

On June 7 and 8, 2000 the Washington State Department of Ecology performed a RCRA Inspection of the Waste Receiving and Packaging Facility. During this inspection, a facility walk down was performed and pertinent documents were requested. On the second day, a meeting was held with Waste Services concerning the Waste Acceptance Program. There were no findings, violations or concerns noted by Ecology.

On Wednesday June 14, 2000 the Washington State Department of Ecology initiated a "Facility Assessment" of the Plutonium Finishing Plant (PFP). The primary focus of the assessment was to obtain a "baseline" of facility operation and identify upcoming activities or transitions that may affect compliance. Ecology is also documenting the current condition of the facility by performing a walk down of the majority of the facility. The group has received a portion of the pertinent documentation requested. The assessment is ongoing and will continue into July. As of Friday, June 30 Ecology has not expressed any concerns to the Plutonium Finishing Plant (PFP) Facility.

On Thursday June 22, 2000, the Environmental Protection Agency Region 10 inspected various facilities on the Hanford site including locations where items and materials with PCB's were stored. Also inspected were facilities/areas that were not assessed during the 1998 Multi Media inspection. There were no findings or concerns generated as a result of this inspection.

On Thursday June 22, 2000 the Washington State Department of Ecology (Ecology) performed a generator inspection of the 274-East 90-Day Accumulation Area and four Satellite Accumulation Areas in the 200 East Area. Those areas included the 2715-EC building (paint shop), the 2715ED building (paint storage), the 272-E (Empty), and the carpenter shop. In a short debrief the inspectors said that at this time they saw no violations. The inspectors requested several documents. After reviewing these documents as well as their field notes, the inspectors will inform the effected facilities if there are any findings or concerns. 
Environmental Services performed the Hanford Site RCRA Permit required inspection of the 100 Areas. No findings were identified.

\section{Crosscutting Compliance/Issue Resolution}

Fluor Hanford (FH) Environmental \& Regulation (E\&R) and Environmental Services (ES) served as environmental points of contact for the recent Hanford Fire Recovery activities. E\&R/ES is assisting in making the notifications, as required by Washington Administrative Code (WAC) 173-303-360(2)(j), that the Hanford Facility has restarted operations. As required by WAC 173-303-360(2)(k), the RCRA Contingency Plan 15-day report is also being prepared.

Environmental Services is coordinating discussions/written input with regulatory professionals, Facility Evaluation Board (FEB), and FH legal to clearly define the Independent Qualified Registered Professional Engineer (IQRPE) role and relationship to the prime contractor.

The WAC 173-303, Dangerous Waste Regulation amendment review for Hanford impacts was coordinated. Impacts have been identified to the responsible organizations and changes to three solid waste procedures have been identified to FH Environment and Regulation.

Review of the Federal Register Advanced Notice for Proposed Rulemaking on improvements to the Land Disposal Restrictions (65 FR 37932) was completed and assistance was provided to support a DOE-HQ comment package. Comments received from FH Projects on company wide review of HNF-PRO-459, "Environmental Training" were dispositioned.

\section{Spill and Release Reporting}

Regulatory reporting was coordinated for thirteen (13) non-reportable releases of a hazardous substance and/or a petroleum product released to the environment. All of these releases were cleaned up and disposed of per state and federal requirements. There were no reportable events, with a release to the environment, there were two (2) reportable code non-compliance events and one (1) informational call that were reported directly to the off site regulatory agency's) by the FH Environmental Single Point of Contact.

The Spill and Release Reporting procedure administrative changes have been completed and sent out for a preliminary review.

\section{Chemical Management}

Procedure HNF-PRO-2258, "Chemical Management" was revised and approved. This revision forms the basis for interim operations until the Chemical Management Program development is complete. HNF-PRO-2258 will then be transformed from a procedure to a requirements document.

The development of several processes in support of the chemical management program were completed, including; the new chemical purchase screening process, the receiving/distribution process, and the Q-level inspection requirements for P-card purchases.

\section{Management and Administrative Support}

A desk instruction and checklist for preparing an Engineering Evaluation/Cost Analysis (EE/CA) was developed. $\mathrm{EE} / \mathrm{CA}$ is a documented approach that $\mathrm{FH}$ is projecting to use for non-time- 
critical removal actions.

A straw man procedure to define the roles and responsibilities of the Environmental Compliance Officer was drafted for Environment and Regulation and submitted to the Environmental Center of Expertise.

The Environmental COE continued to meet and address issues. Meeting minutes were prepared and issued. No new issues were identified.

The Environment and Regulation Website continues to expand. Updates of meeting agendas, minutes continue each month.

The Environmental Triage (ENTR) system (communications tool for managing emerging, new and revised environmental regulations impacts) is undergoing a software audit by the $\mathrm{FH}$ Chief Information Officer (CIO) office. This appears to be a routine effort encompassing six randomly selected Hanford Developed software applications in use by $\mathrm{FH}$.

Technical author support was provided to Environment and Regulation in processing redline/strikeout revisions to align Environmental Protection procedures to the new FH organizational roles and responsibilities.

The 1999 Hanford Site TRI Reporting Compliance Validation Report was completed and submitted on June 21, 2000. This report documents activities leading to the determination that the Hanford Site is not required to submit a Toxic Chemical Release Inventory for calendar year 1999 under the requirements of Section 313 of the Emergency Planning and Community RightTo-Know Act. Submittal of the report also demonstrates completion of Milestone ECP-00-502.

\section{Public Safety and Resource Protection (PSRP)}

- Surface Environmental Surveillance Project staff made a presentation to the Northwest Power Planning Council on June 7, 2000. The presentation addressed tritium, chromium and strontium in the Hanford Reach of the Columbia River.

- Cultural Resources Project staff completed the National Register evaluation for the Bruggeman farm complex during June.

- $\quad$ PNNL Key Milestone RLOT016006 "Complete Spring/Summer Baseline Surveys of $100 / 200$ and 300 Area" was completed on June 29, 2000 on schedule.

- DOE-RL Milestone RLOT016008 "Conduct Bi-Annual Baseline Surveys for Ecological Compliance" was completed on June 29, 2000 on schedule.

- $\quad$ PNNL Key Milestone RLOT016009, "Letter Report to ERC Providing 100 Areas Ecological Data Summary" was completed on June 28, 2000 on schedule.

\section{ISMS STATUS}

Nothing to report at this time. 


\section{BREAKTHROUGHS / OPPORTUNITIES FOR IMPROVEMENT}

Nothing to report at this time.

\section{UPCOMING ACTIVITIES}

- Ecology's schedule for issuing Modification E of the Hanford Facility RCRA Permit continues to slip, and is now projected no earlier than August 2000. As reported previously, this permit revision may contain many permit conditions that may need to be appealed. Resources have been organized to conduct a rapid review and evaluation of the permit; there are only 30 days after issuance to submit an appeal.

- $\quad$ Milestone ECP-00-507, "Annual LDR Report (M-26-01)", is due July 21, 2000.

- $\quad$ The PS and RP Program will complete the 1999 Site Environmental Report (FO Milestone RLOT013003) in September 2000.

COST Performance (M):

\begin{tabular}{|l|c|c|c|}
\hline & BCWP & ACWP & VARIANCE \\
\hline Mission Support 1.8 & $\$ 16.5$ & $\$ 16.6$ & $-\$ .2^{*}$ \\
\hline
\end{tabular}

*Rounding

The $\$ .2$ million (1 percent) unfavorable cost variance is due to several factors. Further information at the PBS level can be found in the following Cost Variance Analysis details.

Schedule Performance (M):

\begin{tabular}{|l|c|c|c|}
\hline & BCWP & BCWS & VARIANCE \\
\hline Mission Support 1.8 & $\$ 16.5$ & $\$ 17.4$ & $-\$ 1.0^{*}$ \\
\hline
\end{tabular}

*Rounding

The $\$ 1.0$ million ( 6 percent) unfavorable schedule variance is due to several factors. Further information at the PBS level can be found in the following Schedule Variance Analysis details. 


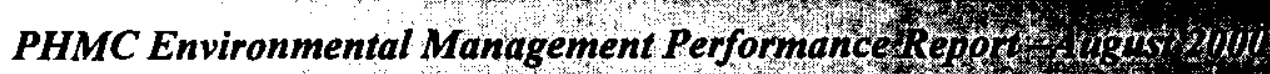

Section I - Mission Support

thes

\section{FY 2000 COSt/SChedule Performance - All Fund Types Cumulative to Date Status - (\$000)}

\begin{tabular}{llllllllll}
\multicolumn{10}{c}{ FYTD } \\
\cline { 2 - 5 } By PBS & BCWS & BCWP & ACWP & SV & $\%$ & CV & $\%$ & PEM & EAC
\end{tabular}

PBS OT01

Mission

WBS 1.8 .2

MYppo

Total

$\$ 17,447 \$ 16,457 \$ 16,646 \$$

(990) $-5.7 \% \$$

(189) $-1.15 \% \$ 23,284$

$\$ 24,950$

\section{COST/SCHEDUle PeRformanCe INDICES (MONTHLY AND FYTD)}

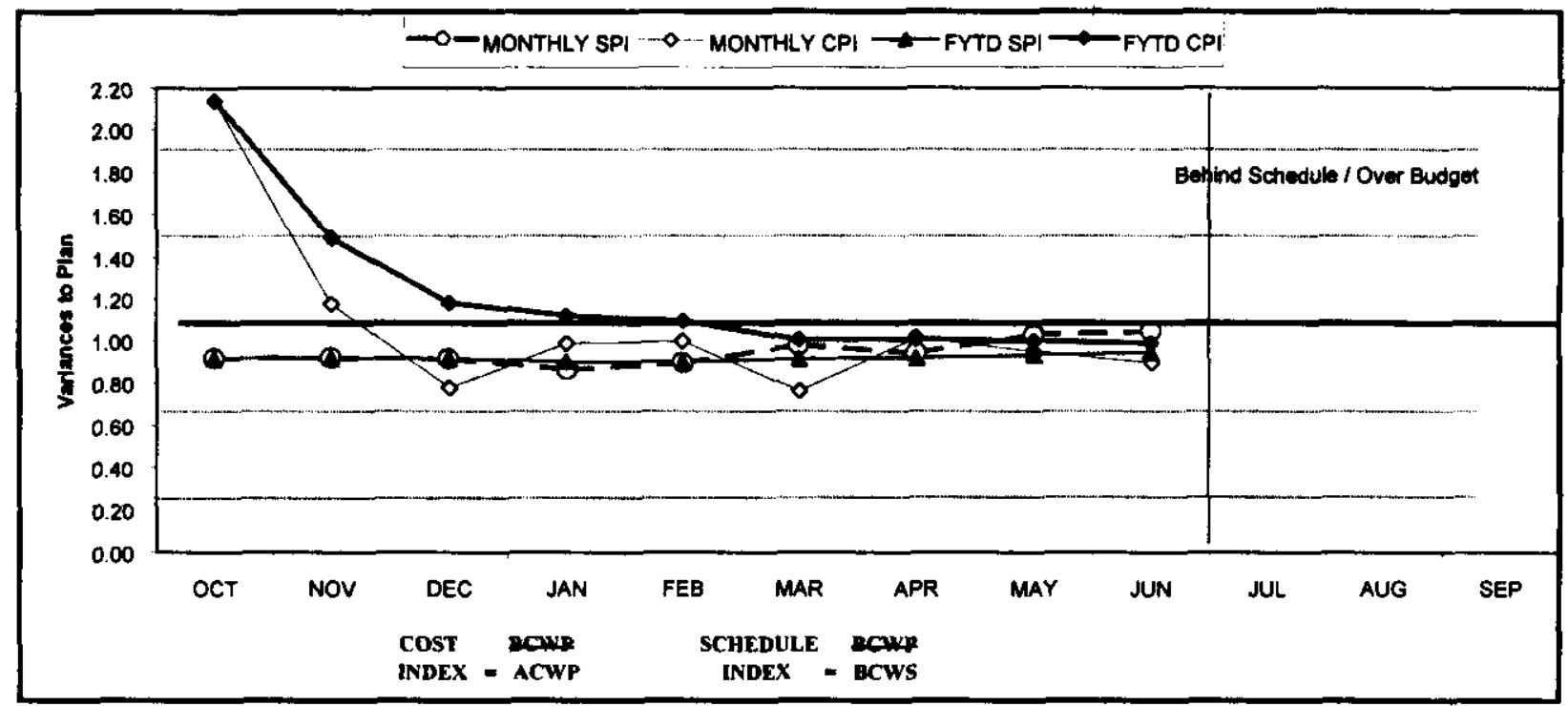

\begin{tabular}{|c|c|c|c|c|c|c|c|c|c|c|c|c|}
\hline FX19:0 & OCL & Noy & DEC & $\mathbf{I A N}$ & FER & MAR & $A P R$ & MAY & 1111 & J11h. & AUIG & SEP \\
\hline MONTHLXSPI & 0.92 & 0.92 & 0.21 & 0.86 & 0.90 & 0.99 & 0.24 & 1.03 & 1.05 & & & \\
\hline MONTHLYCPL & 2.14 & 1.18 & 0.78 & 0.99 & 1.00 & 0.76 & 1.02 & 0.95 & 0.90 & & & \\
\hline EYTD SPL & 0.92 & 0.92 & 0.92 & 0.90 & 0.90 & 0.92 & 0.92 & 0.93 & 0.94 & & & \\
\hline FYTD CPL & 2.14 & 149 & 1.18 & 112 & 100 & 1.01 & -1.01 & 100 & 0.99 & & & \\
\hline MONTHLY BCWS & SI.848 & 52.071 & s1.576 & 52,309 & 51858 & 52.200 & 51.926 & $\$ 2.070$ & .51 .509 & si.771. & 52.024 & $\$ 2.042$ \\
\hline MONTHIY BCWP & 51.694 & 51.907 & $S 1442$ & 51.992 & 51.666 & 57.16 .6 & 51.880 & 52.127 & 51.578 & & & \\
\hline MONTHLYACWP & $\$ 792$ & 51620 & $\$ 1.853$ & 52,022 & 51.668 & 52.837 & 51.852 & 52.241 & 51.762 & & & \\
\hline EYTD BCWS & 51.848 & 53.919 & 55,495 & 57.804 & 59.662 & 514.871 & $\$ 13,867$ & 515,938 & 512447 & $\$ 19.218$ & $\$ 21.241$ & 523,284 \\
\hline FYTD ACWP & $\$ 1694$ & 53.601 & 55.043 & 57.040 & 58.706 & $\$ 10.872$ & $\$ 12.752$ & 514.879 & 516,457 & & & \\
\hline FYTD ACWP & 5792 & 52,412 & $\$ 4.265$ & 56.287 & 52.955 & 510.792 & 512,644 & $\$ 14.884$ & 516.646 & & & \\
\hline
\end{tabular}




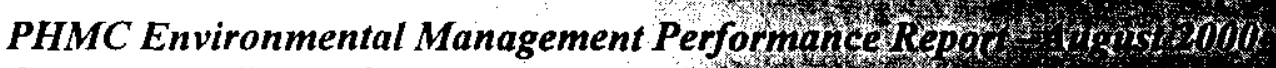

Section I-Mission Support

\section{COST VARIANCE ANALYSIS: (-\$.2 M)}

$\underline{\text { WBS/PBS }}$

Title

\subsection{2/OT01 Mission Support}

Description/Cause: The $\$ 0.2$ million (1 percent) unfavorable cast variance is within acceptable reporting thresholds.

Impact: No impact.

Corrective Action: No corrective action required.

\section{SCHEDULE VARIANCE ANALYSIS: $(-\$ 1.0 \mathrm{M})$}

1.8.2/OT01

Mission Support

Description/Cause: The $\$ 1.0$ million (6 percent) unfavorable schedule variance is within acceptable reporting thresholds.

Impact: No impact.

Corrective Action: No corrective action required.

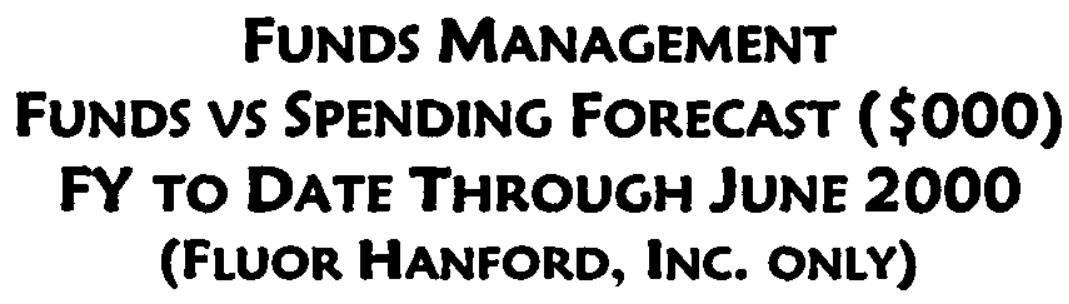

\begin{tabular}{|c|c|c|c|c|c|c|c|c|c|}
\hline & \multicolumn{3}{|c|}{ Project Complotion * } & \multicolumn{3}{|c|}{ Pont 2006 * } & \multicolumn{3}{|c|}{ Line Items " } \\
\hline & Fundes & FYsF & Variance & Punds & FrsF & Varrance & $\begin{array}{c}\text { Expociod } \\
\text { Funds }\end{array}$ & FYSF & Varrances \\
\hline $\begin{array}{l}\text { Multiple Outcomes } \\
\text { i. Mission Support } \\
\text { oTo1, OTOA }\end{array}$ & & & & 16,569 & 15,756 & 813 & & & \\
\hline $\begin{array}{l}\text { Llne Item } \\
\text { Total Mlssion Support Operating }\end{array}$ & & & & 516,569 & 15,736 & 5813 & & & \\
\hline
\end{tabular}

* Control Point

\section{ISSUES}

Nothing to report at this time. 


\section{Baseline Change Requests Currently in Process (\$000)}

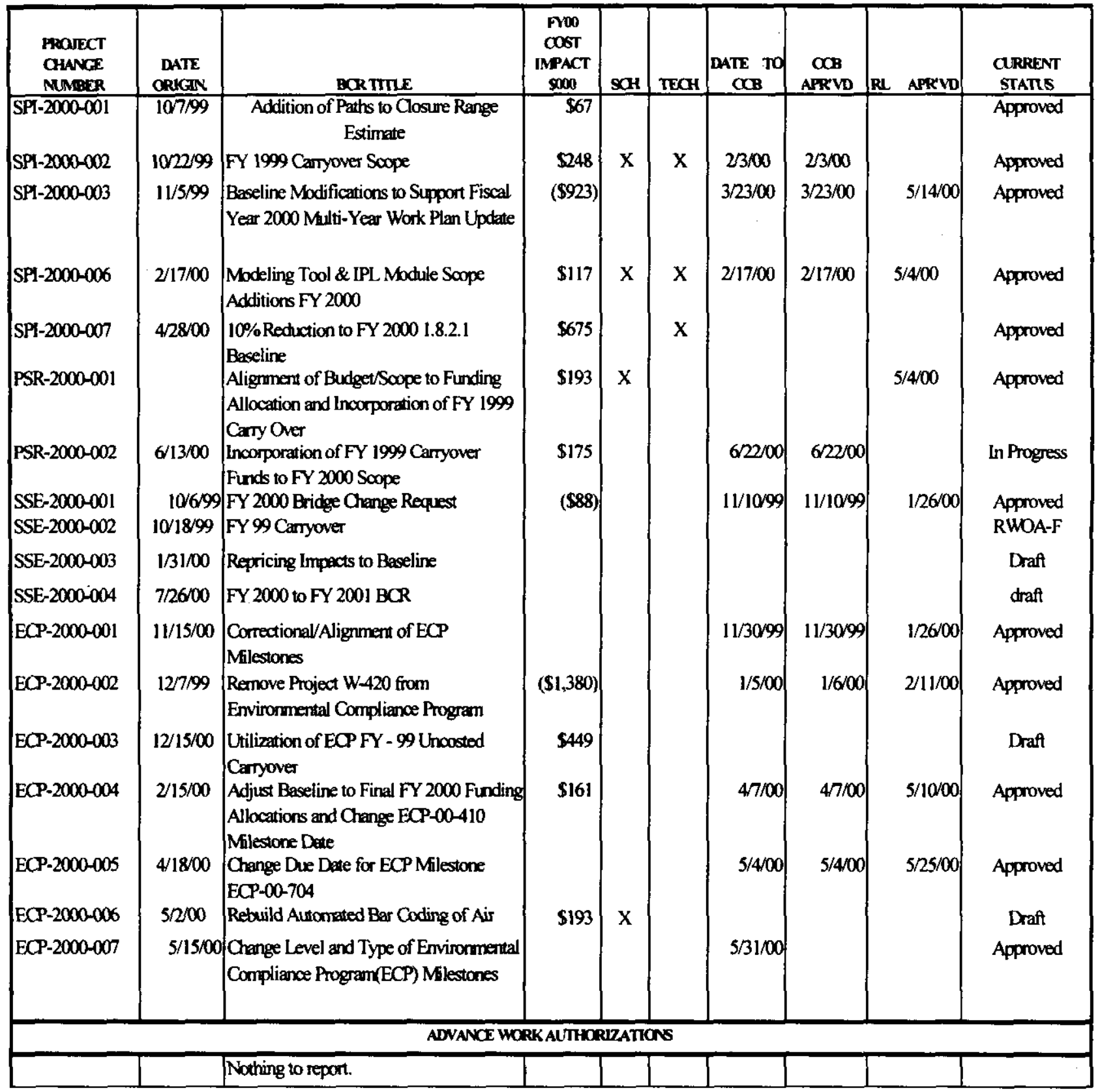


PHMC Environmental Management Performance Report-August 2000

Section I - Mission Support

H

\section{Milestone ACHIEVEMENT}

\begin{tabular}{|c|c|c|c|c|c|c|c|c|}
\hline \multirow[b]{2}{*}{ MILESTONE TYPE } & \multicolumn{4}{|c|}{ FISCAL YEAR-TO-DATE } & \multicolumn{3}{|c|}{ REMAINING SCHEDULED } & \multirow[b]{2}{*}{$\begin{array}{c}\text { TOTAL } \\
\text { FY } \\
2000\end{array}$} \\
\hline & $\begin{array}{c}\text { Completed } \\
\text { Early }\end{array}$ & $\begin{array}{c}\text { Completed } \\
\text { On } \\
\text { Schedule }\end{array}$ & $\begin{array}{c}\text { Completed } \\
\text { Late }\end{array}$ & Overdue & $\begin{array}{c}\text { Forecast } \\
\text { Early }\end{array}$ & $\begin{array}{l}\text { Forecast } \\
\text { On } \\
\text { Schedule }\end{array}$ & $\begin{array}{c}\text { Forecast } \\
\text { Late }\end{array}$ & \\
\hline Enforceable Agreement & 16 & 3 & 0) & 0 & 0 & 7 & 0 & 26 \\
\hline DOE-HQ & 0 & 0 & 0 & 0 & 0 & 2 & 0 & 2 \\
\hline $\mathrm{RL}$ & 7 & 5 & 3 & 0 & 0 & 11 & 0 & 26 \\
\hline Total Project & 23 & 8 & 3 & 0 & 0 & 20 & 0 & 54 \\
\hline
\end{tabular}

\begin{tabular}{|c|c|c|c|}
\hline \multicolumn{4}{|c|}{ Tri-Party Agreement / EA Milestones } \\
\hline Number & Milestone Title & Baseline Date & $\begin{array}{c}\text { Actual } \\
\text { Completion } \\
\text { Date/Status }\end{array}$ \\
\hline ECP-00-302 & $\begin{array}{l}\text { RCRA Permit Class } 1 \text { Mod Notification Quarter } 1 \text { (For Year } \\
\qquad 2000-2046)\end{array}$ & $10 / 01 / 1999$ & $09 / 30 / 1999$ \\
\hline ECP-00-702 & RCRA RPTS/DOCS Closure/Post Closure Cost Est. to RL & $10 / 22 / 1999$ & $10 / 06 / 1999$ \\
\hline ECP-00-901 & Issue Quarterly NESHAP Status RP'T to RL for EPA & $10 / 22 / 1999$ & $10 / 20 / 1999$ \\
\hline EPC-00-306 & Annual Asbestos Notification of Intent (For Year 2000-2046) & $12 / 31 / 1999$ & $12 / 14 / 1998$ \\
\hline ECP-00-303 & $\begin{array}{l}\text { RCRA Permit Class } 1 \text { Mod Notification Quarter } 2 \text { (For FY } \\
\qquad 2000-2046)\end{array}$ & $01 / 01 / 2000$ & $12 / 16 / 1999$ \\
\hline ECP-00-902 & Issue Quarterly NESHAP Status RP'T to RL for EPA & $01 / 28 / 2000$ & $01 / 17 / 1999$ \\
\hline ECP-00-410 & Annual PTRAEU Report to DOE-RL (For FY 2000-2046) & $02 / 01 / 2000$ & Overdue \\
\hline ECP-00-701 & Annual Noncompliance Report to RL & $02 / 17 / 2000$ & $02 / 09 / 2000$ \\
\hline ECP-00-503 & $\begin{array}{l}1999 \text { Hanford Site Annual Dangerous Waste Report (FY } \\
\qquad 2000-2046)\end{array}$ & $02 / 22 / 2000$ & $02 / 22 / 2000$ \\
\hline ECP-00-501 & Tier II Emergency \& Hazardous Chemical Inventory & $02 / 23 / 2000$ & $02 / 23 / 2000$ \\
\hline ECP-00-003 & $\begin{array}{l}\text { Biennial Assess. Of Info. \& Data Access Needs EPA/ECO } \\
\qquad(2000-2046)\end{array}$ & $03 / 31 / 2000$ & $03 / 06 / 2000$ \\
\hline ECP-00-801 & Transmit EIS/ODIS Data to INEEL (FY 2000-2046) & $04 / 01 / 2000$ & $04 / 01 / 2000$ \\
\hline ECP-00-802 & $\begin{array}{l}\text { Issue Annual Non-Radioactive Airborne Emissions Report } \\
\text { (FY 2000-2046) }\end{array}$ & $04 / 01 / 2000$ & $04 / 01 / 2000$ \\
\hline ECP-00-304 & $\begin{array}{l}\text { RCRA Permit Class I Mod Notification Quarter } 3 \text { (For FY } \\
\qquad \begin{array}{l}2000-2046) \\
\end{array}\end{array}$ & $04 / 02 / 2000$ & $04 / 02 / 2000$ \\
\hline ECP-00-904 & Issue Quarterly NESHAP Status Report To RL for EPA & $04 / 21 / 2000$ & $04 / 21 / 2000$ \\
\hline ECP-00-803 & $\begin{array}{l}\text { Issue Annual Radionuclide Air Emissions Report (For FY } \\
\qquad \begin{array}{l}2000-2046)\end{array}\end{array}$ & $06 / 15 / 2000$ & $06 / 14 / 2000$ \\
\hline ECP-00-502 & EPCRA Section 313 Toxic Chemical Release Inventory & $06 / 23 / 2000$ & $06 / 21 / 2000$ \\
\hline ECP-00-504 & Annual PCB Document Log - June & $06 / 23 / 2000$ & $06 / 22 / 2000$ \\
\hline ECP-00-305 & $\begin{array}{l}\text { RCRA Permit Class I Mod Notification Quarter } 4 \text { (For FY } \\
\qquad 2000-2046)\end{array}$ & $07 / 02 / 2000$ & $06 / 26 / 2000$ \\
\hline ECP-00-505 & $\begin{array}{l}\text { PCB Annual Report - July } \\
\end{array}$ & $07 / 07 / 2000$ & \\
\hline ECP-00-507 & Annual LDR Report (M-26-01) & $07 / 21 / 2000$ & \\
\hline ECP-00-906 & Issue Quarterly NESHAP Status Report to RL for EPA & $07 / 28 / 2000$ & \\
\hline ECP-00-703 & $\begin{array}{l}\text { Coordinate RCRA Pípe Mapping and Markíng (For FY } \\
\qquad 2000-2046)\end{array}$ & $09 / 21 / 2000$ & \\
\hline ECP-00-301 & RCRA General Facility Inspections (For FY 2000-2046) & $09 / 30 / 2000$ & \\
\hline \multicolumn{4}{|c|}{ DNFSB Commitments } \\
\hline . & Nothing to report. & & \\
\hline
\end{tabular}




\section{MILESTONE EXCEPTION REPORT}
Number/WBS Level
Milestone Title
Baseline
Forecast
Date
Date

\section{Overdue - 0}

Forecast Late - 0

\section{Performance Objectives}

Nothing to report at this time.

\section{KEY INTEGRATION ACTIVITIES}

- SE\&I and FH Waste Management worked with BHI to resolve discrepancies in ownership and planned completion dates for facilities and release sites reported in IPABS.

- Discussions were held with CHG representatives on forming a joint Interface Control Working Group/Configuration Management (ICWG/CM) working team. An agreement was reached to consider a site-wide ICWG.

- SE\&I supported DynCorp Infrastructure strategic planning. SE\&I is utilizing the Site Systems Analysis Model to provide a life cycle staffing profile for each geographic region on the Site.

- Data from the HSTD was provided to the Accelerated Closure Team to support accelerated closure strategies for SNF and PFP facilities. Recommendations from the team were provided to SE\&I for evaluation in the Site Systems Analysis Model.

- Specific components of the PS\&RP Program are identified as a critical core project within the Groundwater/Vadose Zone Integration Project. As such, key activities relevant to both programs were integrated into FY 2001 detailed work plans as appropriate. 


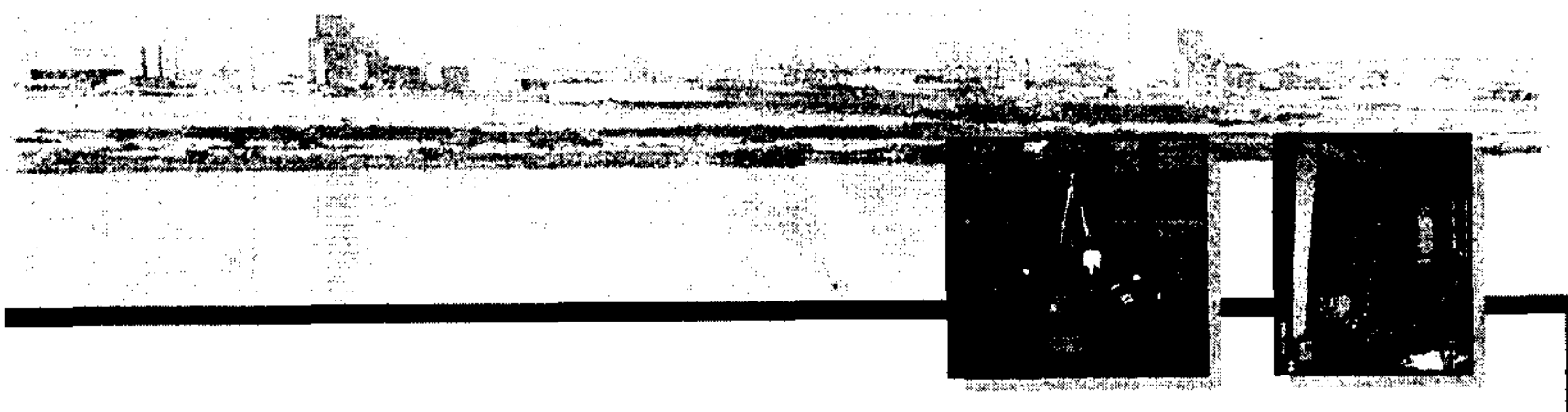

Section J National Programs 


\section{introduction to National Programs}

DOE EM is responsible for a variety of National Programs. DOE-HQ typically provides operations policy and programmatic guidance to one or more field office that serve as lead for individual programs. FH currently supports the following National Programs: Transportation and Packaging (PBS OT02) and Pollution Prevention and Waste Minimization (PBS WM07).

Transportation and Packaging provides full-service transportation and packaging capabilities. Packaging services for radioactive and hazardous cargo is provided, including regulatory safetybasis documentation, certification, and licensing. Packaging plans and logistical studies for major shipping campaigns are also provided, as well as approved training courses in transportation safety and waste management. Transportation and traffic logistics management, engineering and operational support to offsite customers, carrier selection and evaluation, automated transportation management systems used by the U.S. Department of Energy (DOE) complex and commercial vendors, and international transport of hazardous and radioactive packages are other services provided.

Pollution Prevention and Waste Minimization (P2/WMin) coordinates the development and implementation of a Hanford Site P2/WMin Program to comply with Federal, state, and DOE directives. The program's purpose is to achieve Site objectives through effective and efficient methodologies tailored to generator activities and operations.

\section{ACCOMPLISHMENTS}

- $\quad$ Preparations are continuing to prepare the "Draft Hanford Site FY 2001 Strategy for Meeting the Secretary of Energy's FY 2005 P2/WMin Goals."

- A presentation was made to RL by FH-Transportation and Packaging (T\&P) Program Office for the development of the Hanford Site "Minimum Packaging Standards" (MPS).

- $\quad$ FH T\&P Program Office received a thank you from RL for the excellent work completing the ECN to the Lead Lined Drum Safety Analysis Report for Packaging (SARP) in a timely and efficient manner. The revisions to the safety analysis for the tiedown and Gas Generation sections of the SARP were well done and of high quality. The DOE Authorization Basis Division (ABD) review of the $\mathrm{ECN}$ was easier to perform due to the efforts of the T\&P Program office. This allowed the facility to start safely shipping waste pending the formal review and approval of the revised Lead Lined Drum SARP. 


\section{FY 2000 Cost/SChedule Performance - All Fund TyPes Cumulative to Date Status - $(\$ 000)$}

FYTD

\begin{tabular}{|c|c|c|c|c|c|c|c|c|c|c|}
\hline & By PBS & $\overline{B C W S}$ & BCWP & ACWP & $\mathbf{S V}$ & $\%$ & $\overline{C V}$ & $\%$ & PEM & EAC \\
\hline $\begin{array}{l}\text { PBS OT02 } \\
\text { WBS } 1.11\end{array}$ & $\begin{array}{l}\text { Transportation \& } \\
\text { Packaging (RL 7601) }\end{array}$ & $\$ 1,686$ & $\$ 1,910$ & $\$ 1,271$ & $\$ 224$ & $13 \%$ & 639 & $33 \%$ & $\$ 2,319$ & $\$ 2,468$ \\
\hline \multirow[t]{2}{*}{ PBS WM07 } & $\begin{array}{l}\text { Waste Minimization } \\
\text { (RLHQ 7770) }\end{array}$ & $\$ 2,027$ & $\$ 2,027$ & $\$ 1,565$ & $(0)$ & $0 \%$ & 462 & $23 \%$ & $\$ 3,681$ & $\$ 3,681$ \\
\hline & Total & $\$ 3,713$ & $\$ 3,937$ & $\$ 2,836$ & $\$ 224$ & $6 \%$ & $\$ 1,101$ & $28 \%$ & $\$ 6,000$ & $\$ 6,149$ \\
\hline
\end{tabular}

Cost/Schedule Performance Indices (MONTHLY AND FYTD)

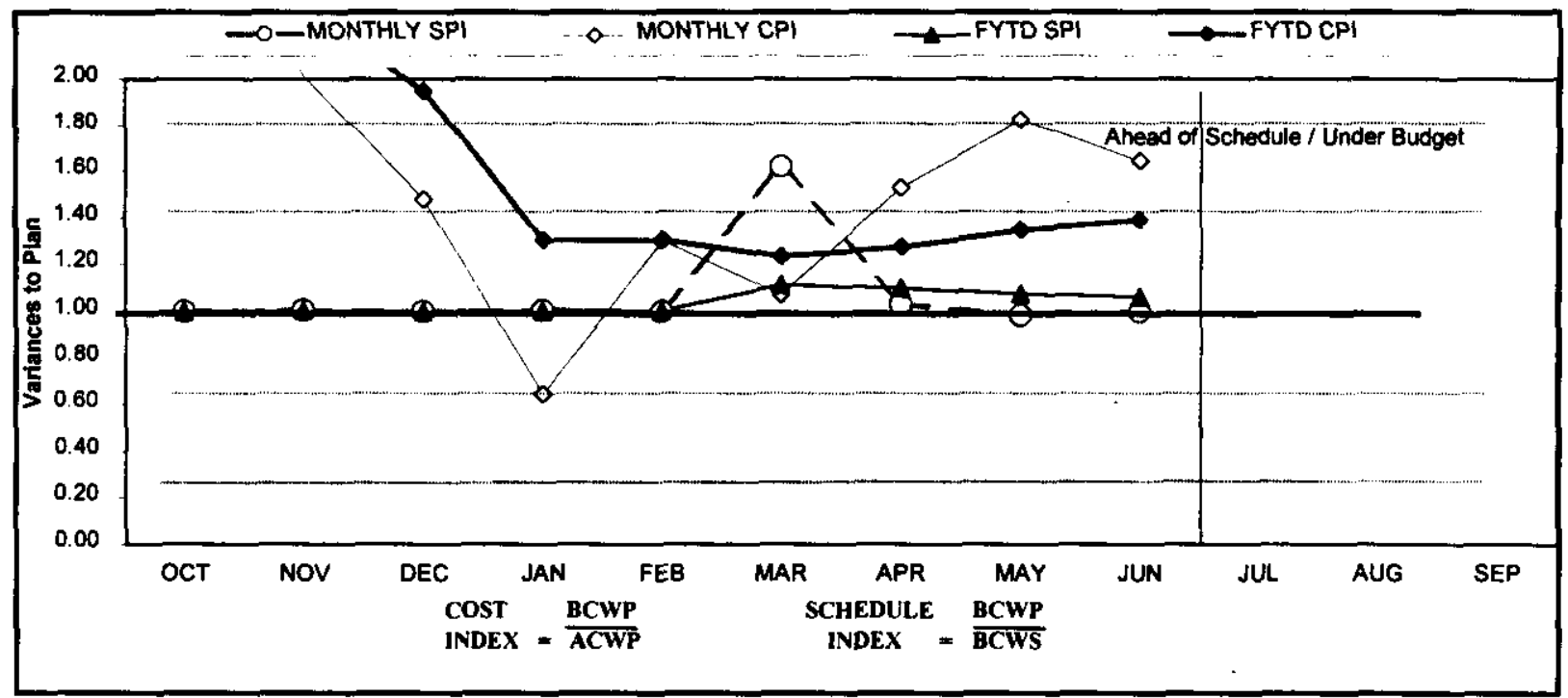

\begin{tabular}{|c|c|c|c|c|c|c|c|c|c|c|c|c|}
\hline FY 2000 & OCT & NOV] & DXC & JA1 & F2B & MAK & APR & MAY & JuN & JUL & AUG & SEP \\
\hline MONIHLYSPI & 1.00 & 7.00 & 1.00 & 1.00 & 1.00 & 1.62 & 1.03 & 0.98 & 1,00 & & & \\
\hline MONIFIYYCP & 2.81 & 2.01 & T.48 & 0.65 & T.30 & T.07 & $T .53$ & T.82 & 1.64 & & & \\
\hline FYIDSPI & $T .00$ & $T .00$ & $T .00$ & 7.00 & 1.00 & I.T & T.10 & 1.07 & 1.06 & & & \\
\hline FYTDCPI & 2.81 & 2.30 & 1.95 & 7.30 & 1.30 & $T .23$ & $T .27$ & 1.35 & 1.39 & & & \\
\hline MONIRLYBCWS & 304 & 383 & 328 & 329 & 324 & 361 & 398 & का & 674 & 561 & 675 & T,0ST \\
\hline MONIRLY BCWP & 5303 & 384 & 328 & 330 & 324 & 385 & 409 & 601 & 672 & & & \\
\hline MONIFICYACWP & 5708 & पश & 222 & 512 & 249 & 547 & 268 & 330 & 5409 & & & \\
\hline FYTDECWS & 5304 & 5687 & 1,015 & 1,345 & 51,669 & 2,030 & 2,428 & $-3,039$ & 53,713 & 54,274 & 4,949 & 6,000 \\
\hline FYTU ACWP & 108 & 299 & 325 & 7,033 & 51,282 & T,829 & 2,046 & 2,427 & 52,836 & & & \\
\hline
\end{tabular}




\section{FUNDS MANAGEMENT FUNDS VS SPENDINC FORECAST ( $\$ 000)$ FY TO DATE THROUGH JUNE 2000 (FLUOR HANFORD, INC. ONLY)}

\begin{tabular}{|c|c|c|c|c|c|c|c|c|c|}
\hline & \multicolumn{3}{|c|}{ Project completion } & \multicolumn{3}{|c|}{ Post 2006 } & \multicolumn{3}{|c|}{ Line tems } \\
\hline & $\begin{array}{l}\text { Expsectiod } \\
\text { Funds }\end{array}$ & FYSF & Veriance & $\begin{array}{l}\text { Expovelior } \\
\text { Funds }\end{array}$ & FYSF & Variance & $\begin{array}{l}\text { Expipetiva } \\
\text { Funds }\end{array}$ & FYSF & Verlence \\
\hline 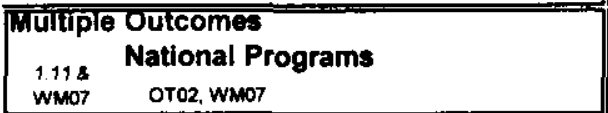 & & & & 6,150 & 4,476 & 1,674 & & & \\
\hline Liñeltem & & & & & & & & & \\
\hline Total National Programs Operating & & & & 6,150 & 4,476 & $\$ 7,674$ & & & \\
\hline 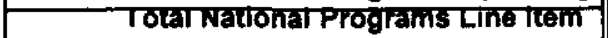 & & & & & & & & & \\
\hline
\end{tabular}

* Control Point

\section{COST VARIANCE ANALYSIS: (+\$1.1M)}

\section{WBS/PBS $\quad$ Title}

1.11.1/OT02 Transportation and Packaging

Description and Cause: The $\$ 639 \mathrm{~K}$ ( 33 percent) favorable cost variance is due to no MCEP evaluations being done because of a major change in the MCEP. When the revision is complete, MCEP field audits will resume which will increase both travel and labor costs. Additionally, the ATMS/ETAS integration project will not be started until FY 2001, at the request of the NTP customer.

Impact: None.

Corrective Action: MCEP spending curve will increase in the later half of the year.

\subsection{2/WM07 Pollution Prevention/Waste Minimization}

Description and Cause: The $\$ 462 \mathrm{~K}$ ( 23 percent) favorable cost variance is due to staffing shortfalls in first half of year.

Impact: None

Corrective Action: Under-runs will be utilized to offset funding shortfall in Fiscal Year 2001.

\section{SCHEDUle VARIANCE ANALYSIS: $(+\$ 0.2 \mathrm{M})$}

\section{WBS/PBS $\quad$ Title}

\subsection{1/OT02 Transportation and Packaging}

Description and Cause: The $\$ 224 \mathrm{~K}$ ( 13 percent) favorable schedule variance is due to program efficiencies.

Impact: None.

Corrective Action: None. 


\section{Richland Operations Office Environmental Restoration}

\section{Environmental Management Performance Report}

August 2000

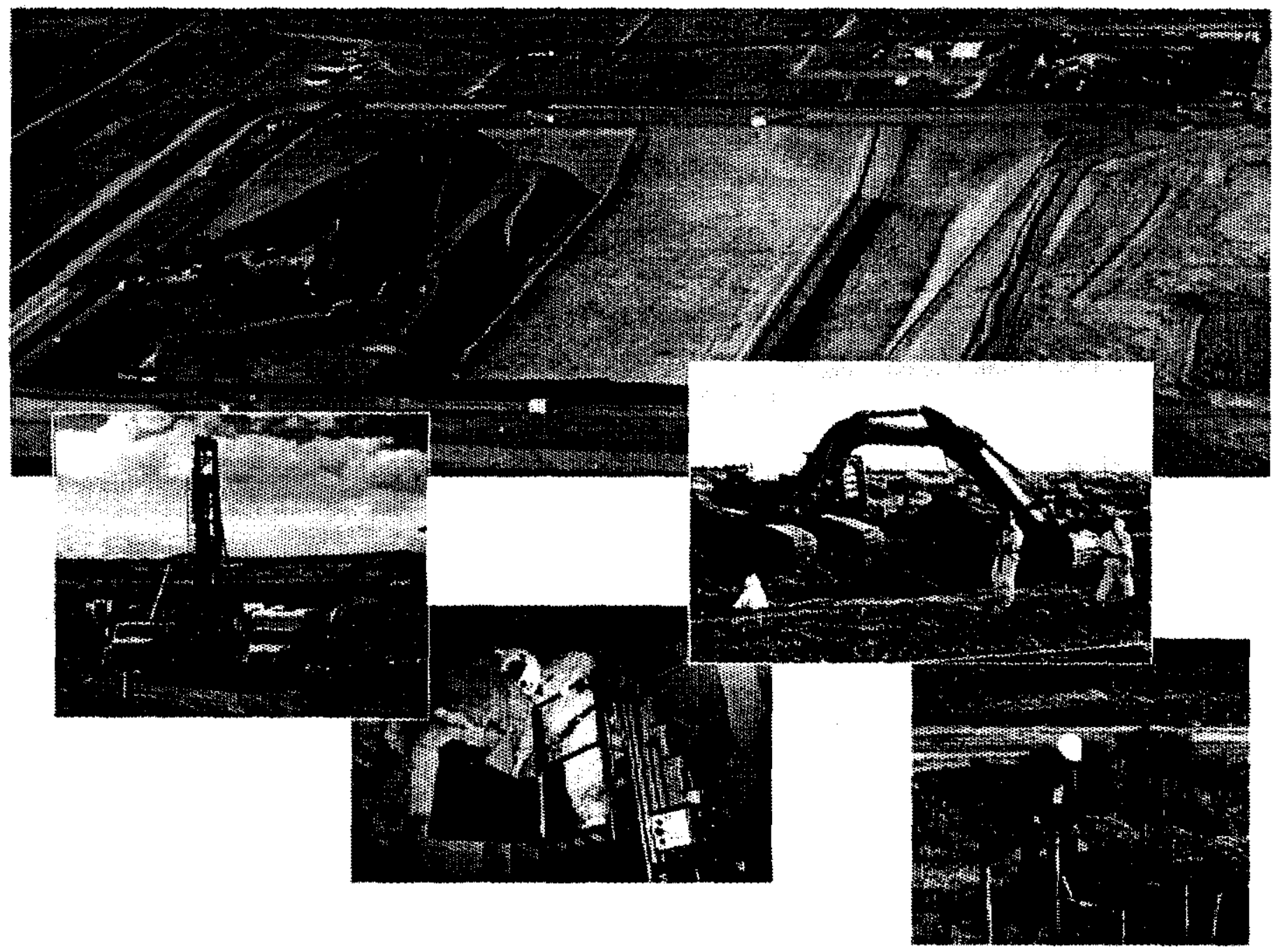

Focused on Progress...

Focused on Outcomes!

Department of Energy Richland Operations Office

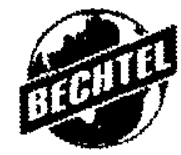

Bechtel Hanford, Inc.

Environmental Restoration Contractor 


\section{ENVIRONMENTAL RESTORATION PERFORMANCE REPORT ENVIRONMENTAL RESTORATION \\ AUGUST 2000}

TABLE OF CONTENTS

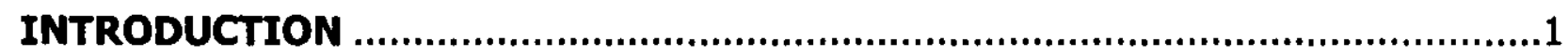

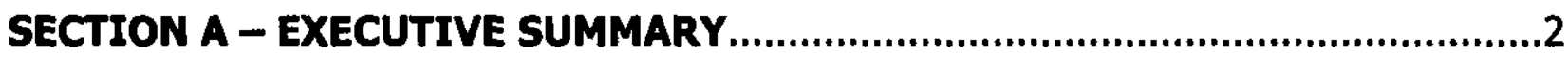

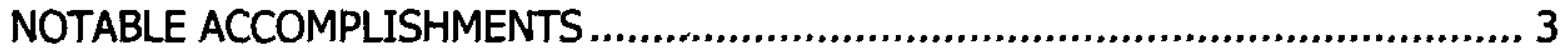

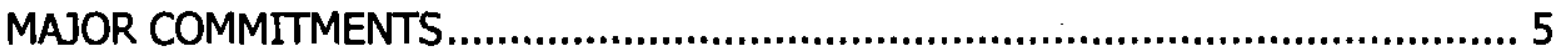

SAFETY/ISMS/CONDUCT OF OPERATIONS ..................................................... 7

REGULATORY/EXTERNAL/DOE-RL \& HQ ISSUES AND REQUESTS $\ldots . . \ldots \ldots \ldots \ldots \ldots . \ldots 11$

TOTAL COST/SCHEDULE OVERVIEW......................................................12

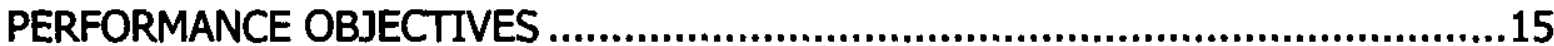

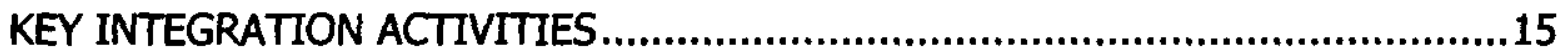

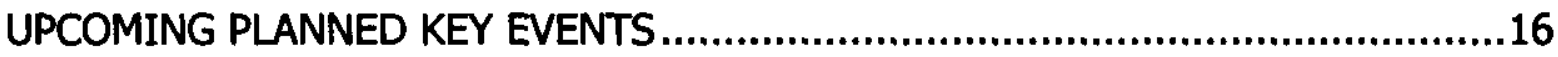

SECTION B - RESTORING THE RIVER CORRIDOR PROJECT SUMMARIES......17

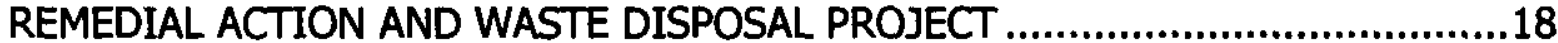

DECOMMISSIONING PROJECTS................................................................27

PROGRAM MANAGEMENT AND SUPPORT ..................................................34

SECTION C - TRANSITIONING THE CENTRAL PLATEAU PROJECT

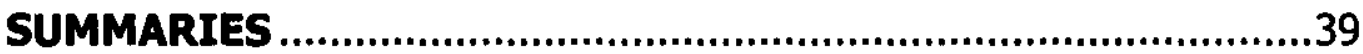

GROUNDWATER/VADOSE ZONE INTEGRATION PROJECT ...................................40

SURVEILLANCE/MAINTENANCE AND TRANSITION PROJECTS ..........................5 


\section{ENVIRONMENTAL RESTORATION PERFORMANCE REPORT ENVIRONMENTAL RESTORATION AUGUST 2000}

\section{INTRODUCTION}

The monthly Environmental Restoration (ER) Environmental Management Performance Report consists of three sections: Section A - Executive Summary, Section B - Restoring the River Corridor Project Summaries, and Section C - Transitioning the Central Plateau Project Summaries. All cost, schedule, milestone commitments, performance measures, and safety data is current as of June 30. Accomplishments, Issues and Integration items are current as of July 27, unless otherwise noted.

Section A - Executive Summary. This section provides an executive level summary of Bechtel Hanford, Inc.'s (BHI) performance information for the current reporting month and is intended to bring to Management's attention that information considered to be most noteworthy. The Executive Summary begins with a description of notable accomplishments that are considered to have made the greatest contribution toward safe, timely, and cost-effective cleanup. Major commitments are summarized that encompass Hanford Federal Facility Agreement and Consent Order (Tri-Party Agreement) milestones and FYOO Management Commitment milestones. Safety statistics are also included. Issues that require management and/or regulator attention and resolution status are addressed. Fiscal year-to-date ERC Project cost and schedule variance analysis is summarized. The Key Integration Activities section highlights site activities that cross contractor boundaries and demonstrates the shared value of working as a team to accomplish the work. The Executive Summary ends with a listing of major upcoming planned key events within a 90-day period.

Section B - Restoring the River Corridor. This section contains more detailed monthly activity information and performance status for the three projects within the 'Restoring the River Corridor' outcome. These three projects consist of the Remedial Action and Waste Disposal Project, Decommissioning Projects, and the Program Management and Support (PM\&S) Project.

Section C - Transitioning the Central Plateau. This section contains more detailed monthly activity information and performance status for the two projects within the 'Transitioning the Central Plateau' outcome. These two projects consist of the Groundwater/Vadose Zone (GW/VZ) Integration Project and the Surveillance/Maintenance and Transition (SM\&T) Projects.

Information in this report is identified with a green, yellow, or red text box used as an indicator of the overall status. Green indicates work or issue resolution is satisfactory and generally meets or exceeds requirements; yellow indicates that significant improvement is required; and red indicates unsatisfactory conditions requiring immediate corrective actions. 


\section{ENVIRONMENTAL RESTORATION PERFORMANCE REPORT ENVIRONMENTAL RESTORATION AUGUST 2000}

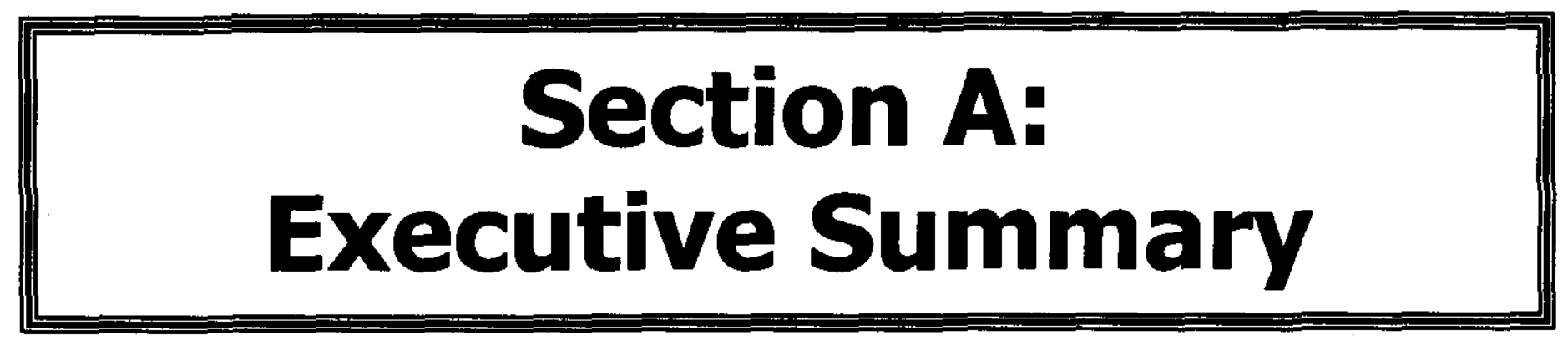




\section{ENVIRONMENTAL RESTORATION PERFORMANCE REPORT ENVIRONMENTAL RESTORATION \\ AUGUST 2000}

\section{SECTION A - EXECUTIVE SUMMARY}

Financial / Performance Measures data as of month-end June. All other data as of July 27, 2000 (unless otherwise noted).

\section{NOTABLE ACCOMPLISHMENTS:}

\section{River Corridor:}

On June 7, the first shipment of waste was placed into Cell \#4 at the Environmental Restoration Disposal Facility (ERDF). Construction of Cells \#3 and \#4 was completed in December 1999 which doubled the capacity of the disposal facility. Also, the first $K$ Basin waste shipment from the Spent Nuclear Fuel Project was transported to the ERDF on June 26.

All planned fiscal year 2000 (FYO0) pipeline remediation was completed in the 100 D Area on June 14, and backfilling activities were initiated. Closure verification package sampling began on the $100 \mathrm{H}$ Area pipeline overburden stockpiles.

Two off-the-shelf technologies (geo-probe and sodium iodide detector) were deployed at the $100 \mathrm{~F}$ Area ash pit to perform in situ characterization that resulted in $50 \%$ reduction in waste site volume. Preliminary cost savings is estimated at \$5M.

Remediation activities were initjated in the $100 \mathrm{~N}$ Area on July 21, meeting the requirement of the Hanford Site Resource Conservation and Recovery ACt (RCRA) permit.

Public comment period was completed for the 100 Area Burial Ground Focused Feasibility Study and Proposed Plan. Comments will be incorporated into the documents. The 100 Area Burial Ground Record of Decision is scheduled for completion by September 30.

Excavation was completed at Landfills $1 A$ and 18 located in the 300 Area during June. In addition, the lead-contaminated soil that had been stockpiled in Landfill 10 was shipped to ERDF in accordance with the recently approved variance.

On June 29, Revision 0 of the 300-FF-2 Operable Unit Focused Feasibility Study and Proposed Plan were transmitted to the regulators. Public comment period was initiated on July 3.

The F Reactor Hazards Assessment and Characterization Report was transmitted to the U.S. Environmental Protection Agency (EPA) on June 19. This satisfies completion of Tri-Party Agreement Target Milestone M-93-08-T1 that was due on June 30.

Demolition of the DR Reactor fuel storage basin (above-grade and below-grade), transfer bay, and monitor room was completed the last week in June.

The draft B Reactor Safe Storage Phase II Feasibility Study was transmitted to the U.S. Department of Energy (DOE), Richland Operations Office (RL) on June 27. Rough-order-ofmagnitude estimates for B Reactor hazards mitigation (outside of the feasibility study scope) were also transmitted. RL transmitted the documents to the EPA on July 10. Submission of these documents was made to meet the requirements of Tri-Party Agreement Milestone M-9305.

The Draft 8 Engineering Evaluation/Cost Analysis (EE/CA) documents for D and H Reactor Interim Safe Storage (ISS) were submitted for $R L$ and regulator review. The $H$ Reactor Auditable Safety Analysis (ASA) was transmitted to RL on June 30. The D Reactor ASA comment resolution was also completed in June.

Removal of all 70 plastic polymethyl methacrylate (PMMA) panels from the process hood east face was completed ahead of schedule in the 233-S Plutonium Concentration Facility during June. The first fixative application was also completed in the process hood. 


\section{ENVIRONMENTAL RESTORATION PERFORMANCE REPORT ENVIRONMENTAL RESTORATION \\ AUGUST 2000}

\section{NOTABLE ACCOMPLISHMENTS continued:}

The FYO1 - 03 Detailed Work Plan (DWP) kickoff meeting was held on June 5 with ERC, RL, regulator, and stakeholder representatives in attendance.

\section{Central Plateau:}

The Groundwater/Nadose (GW/VZ) Integration Project participated in the Oregon Hanford Waste Board meetings conducted during June and assisted DOE, Headquarters (HQ) in the transmittal and distribution of the Semi-Annual Groundwater/Nadose Zone Report to members of the Northwest Congressional Delegation.

The construction contract for the In Situ Redox Manipulation (ISRM) evaporation pond was awarded, and field work commenced in June. The first chemical injection is planned for late July.

The draft waste management plan that addresses the tritium investigation of the 618-11 burial ground was approved by the regulators in mid July. A waste pad is also being prepared in the 300 Area for investigative derived waste.

All five groundwater pump and treat systems continued removing contaminants from the groundwater. All operated above cumulative planned availability through June.

All field work and final report associated with the reduction oxidation (REDOX) miscellaneous contaminated area stabilization were completed.

Construction and startup were completed for the $100 \mathrm{~N}$ Area water plant.

The KE/KW acid tank sample work activities were completed. The tanks were sampled and found that they can be treated as noncontaminated waste.

All 84 passive vents were sealed at the Radiation Area Remedial Action (RARA) sites approximately three weeks ahead of schedule.

In June, six cells were accessed at the U Plant (221-U Building) canyon facility in support of the Canyon Disposition Initiative (CDI). Only one cell remains to be accessed. A total of $38 \mathrm{cells}$ will have been accessed upon project completion. 


\section{ENVIRONMENTAL RESTORATION PERFORMANCE REPORT ENVIRONMENTAL RESTORATION \\ AUGUST 2000}

\section{MAJOR COMMITMENTS:}

\section{Tri-Party Agreement Milestones:}

Twelve Tri-Party Agreement milestones have been completed through June, all ahead of schedule. One milestone was completed behind schedule.

\begin{tabular}{|c|c|}
\hline Total Tri-Party Agreement Mllestones Due in Froo & 16 \\
\hline Total Planned Through June & 13 \\
\hline Total Completed Through June & 12 \\
\hline
\end{tabular}

\begin{tabular}{|l|c|}
\hline Remaining Tri-Party Agreement Mllestones to be Completed in Froo & 4 \\
\hline Forecast Ahead of Schedule & 1 \\
\hline Forecast On Schedule & 2 \\
\hline Forecast Behind Schedule & $1^{*}$ \\
\hline
\end{tabular}

*The $B$ Reactor documents were submitted to DOE-RL (PM) on June 27 and delivered to the DOE-RL Office of Regulatory Liaison on June 28 for concurrence and submittal through the remainder of the signature cycle. The document was received by the regulators on July 10, ten days later than the milestone completion date of June 30 (TPA Milestone M-93-05).

\section{FYoo Management Commitment MIlestones:}

Transmit Update of the Vadose Zone Science and Technology Roadmap (PBS VZO1) due April 30.

Status: Complete. Draft was transmitted to RL on April 28.

Install Wells and Initiate Injection of the Barrier for Phase I of the In Situ REDOX Groundwater Remediation (PBS ERO8) due September 30.

Status: Forecasted for completion by September 30. (16-well installation completed on April 24.)

Complete the Semi-Annual Groundwater/Vadose Zone Report (December 1999 - March 2000) (PBS VZO1) due May 31.

Status: Complete. Final document was transmitted to RL on May 31. 


\section{ENVIRONMENTAL RESTORATION PERFORMANCE REPORT ENVIRONMENTAL RESTORATION \\ AUGUST $\mathbf{2 0 0 0}$}

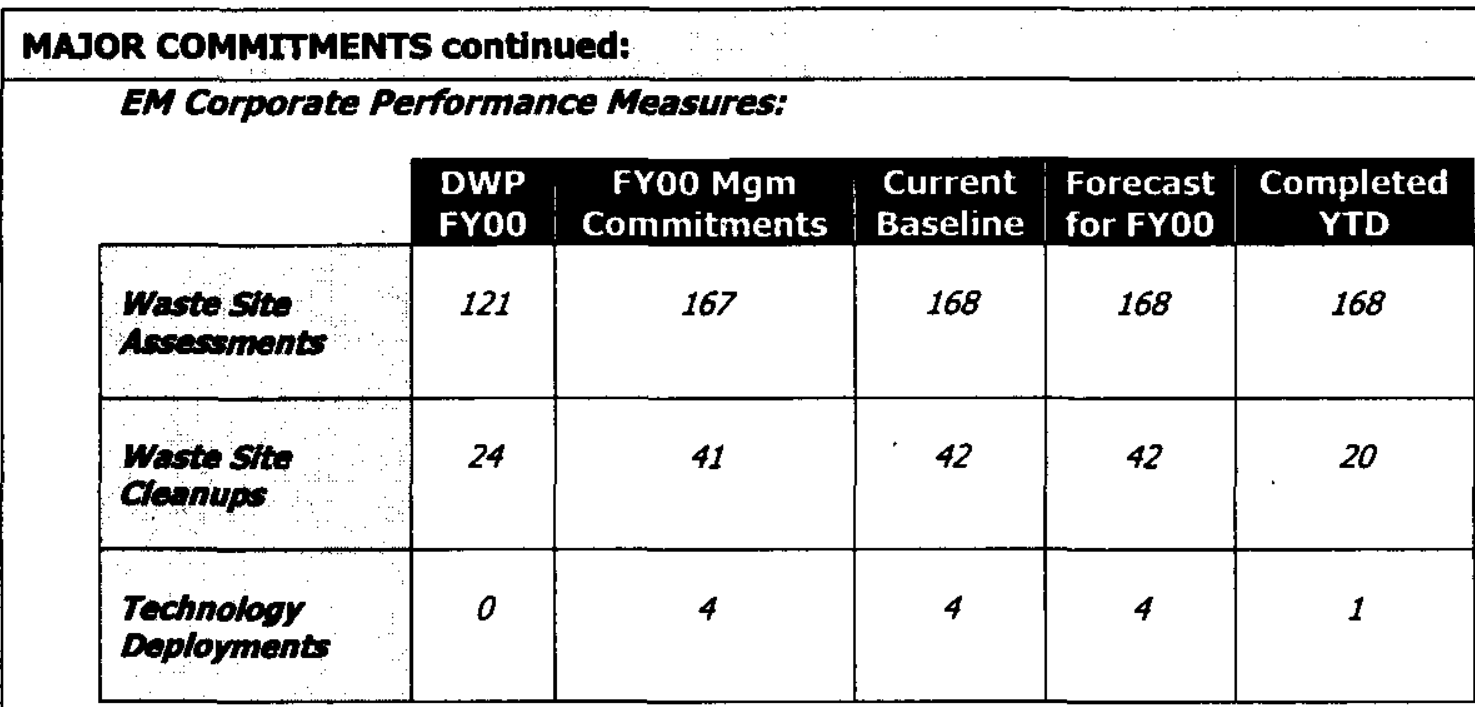




\section{ENVIRONMENTAL RESTORATION PERFORMANCE REPORT ENVIRONMENTAL RESTORATION \\ AUGUST 2000}

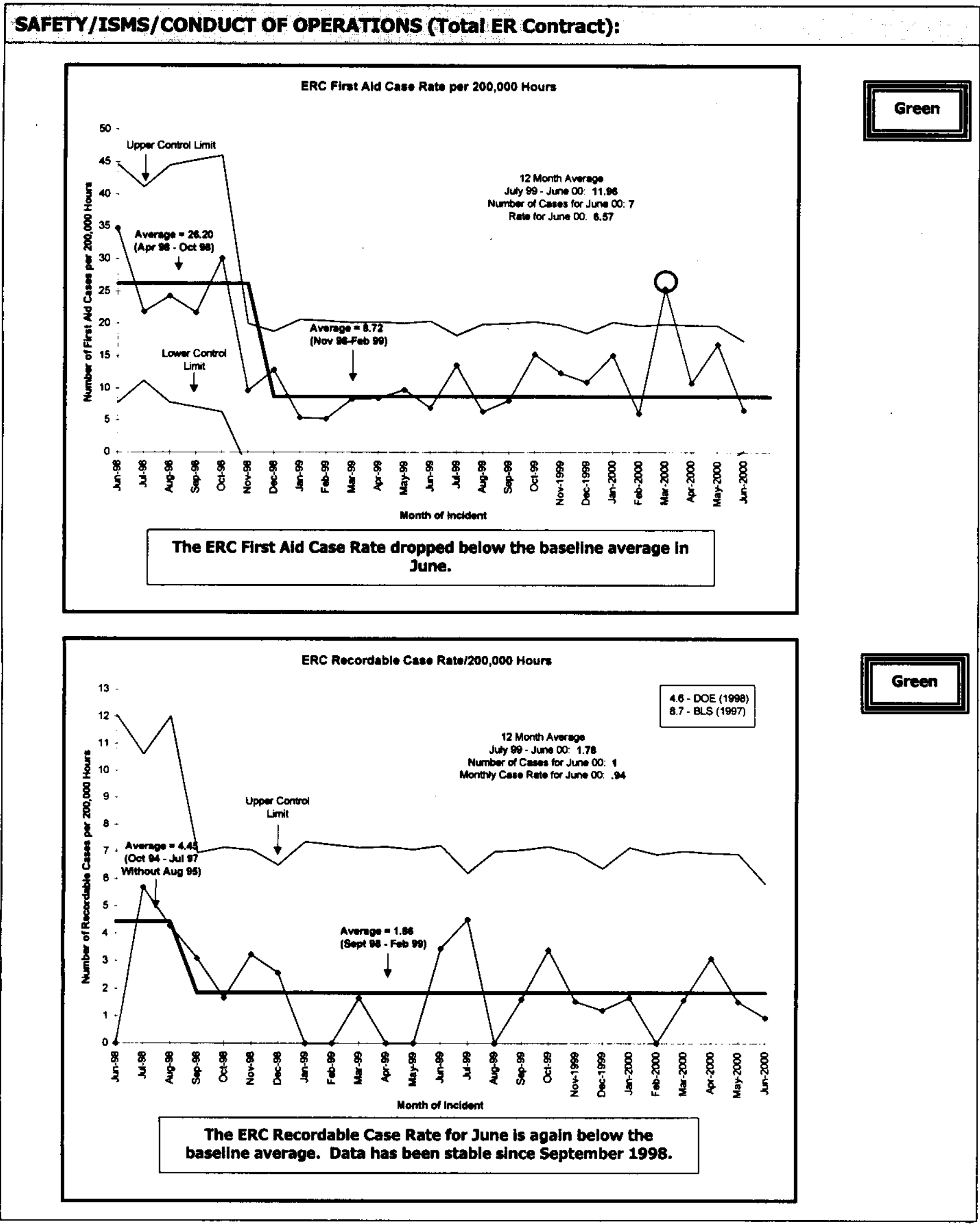




\section{ENVIRONMENTAL RESTORATION PERFORMANCE REPORT ENVIRONMENTAL RESTORATION \\ AUGUST 2000}

\section{SAFETY/ISMS/CONDUCT OF OPERATIONS (Total ER Contract) continued:}

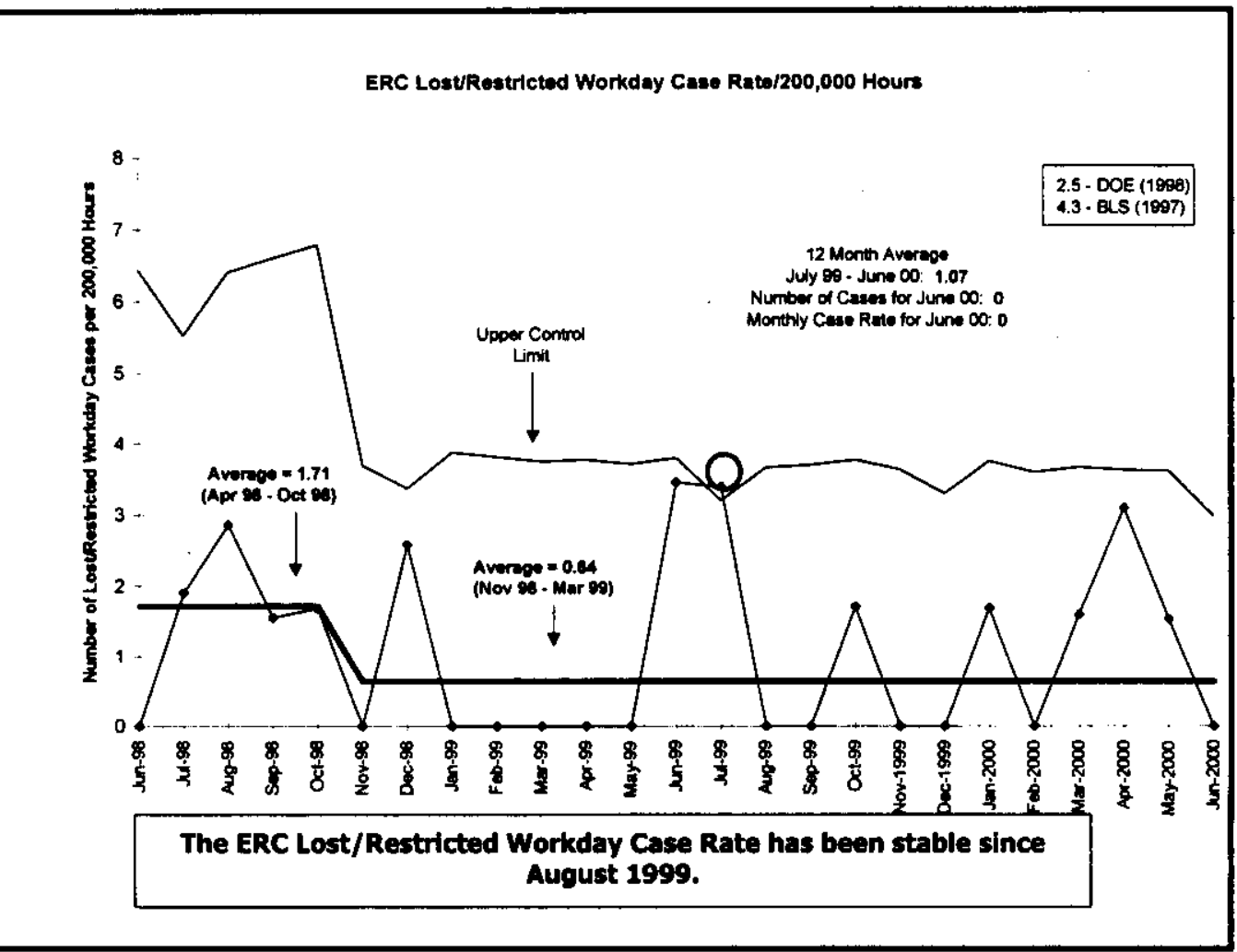

Safety:

\begin{tabular}{|l|c|c|c|}
\cline { 2 - 4 } & YTD $\begin{array}{c}\text { Current } \\
\text { Month } \\
\text { (May) }\end{array}$ & \multicolumn{1}{c|}{ Current Month Comments } \\
\hline FIrst Ald & 80 & 7 & $\begin{array}{l}\text { (1) puncture, (2) sprains/strains, (1) } \\
\text { abrasion, (1) irritation, (2) bite/sting }\end{array}$ \\
\hline Restricted Workday Case & 5 & 0 & N/A \\
\hline Last Wonkday Case & 1 & 0 & N/A \\
\hline OsHiA Recordable & 10 & 1 & (1) irritation to eyes \\
\hline
\end{tabular}

- The ERC, as of June 22, 2000, reports 1,238,100 hours since the last lost workday incident.

-The last lost workday began October 8, 1999. 


\section{ENVIRONMENTAL RESTORATION PERFORMANCE REPORT ENVIRONMENTAL RESTORATION \\ AUGUST 2000}

\section{SAFETY/ISMS/CONDUCT OF OPERATIONS (Total ER Contract) continued: \\ ISMS: \\ DOE EM Performance Agreement: Develop and implement Integrated Safety Management \\ (ISM) - September 30, 2000}

Status:

- Continuing our effort on the closure of the multi-discipline action plan. It is scheduled for completion by September 30, 2000. All other actions have been completed.

- The revised Integrated Environment, Safety, and Health Management System Description Document (BHI-01199, Rev. 2) has been distributed to the entire ERC Management Team.

- Continuous improvement and employee awareness of ISMS is ongoing through the ISMS Question of the Day Program and the distribution of ISMS Awareness Badges (over 1000 distributed) and "ISMS =The Way We Do Work" lanyards (over 800 distributed to date and 300 on back order) to ERC employees.

- The integration of the ISMS program into the Environment, Safety, and Health Handbook has been completed and approved. This handbook is currently in printing and will be issued to all ERC employees this summer.

- The Detailed Work Plan (DWP) for FY 2001 is currently under development. ISMS Program responsibility will be transitioned to the QS\&H Department Manager for the next fiscal year.

- At the request of DOE-RL management, BHI was requested to support DOE in resolving their ISMS Opportunities for Improvement (OFIs), develop an action plan to address the OFIs, identify key personnel, develop a schedule for completion, and oversee the implementation of the plan throughout $R L$ 's structure. 


\section{ENVIRONMENTAL RESTORATION PERFORMANCE REPORT ENVIRONMENTAL RESTORATION \\ AUGUST 2000}

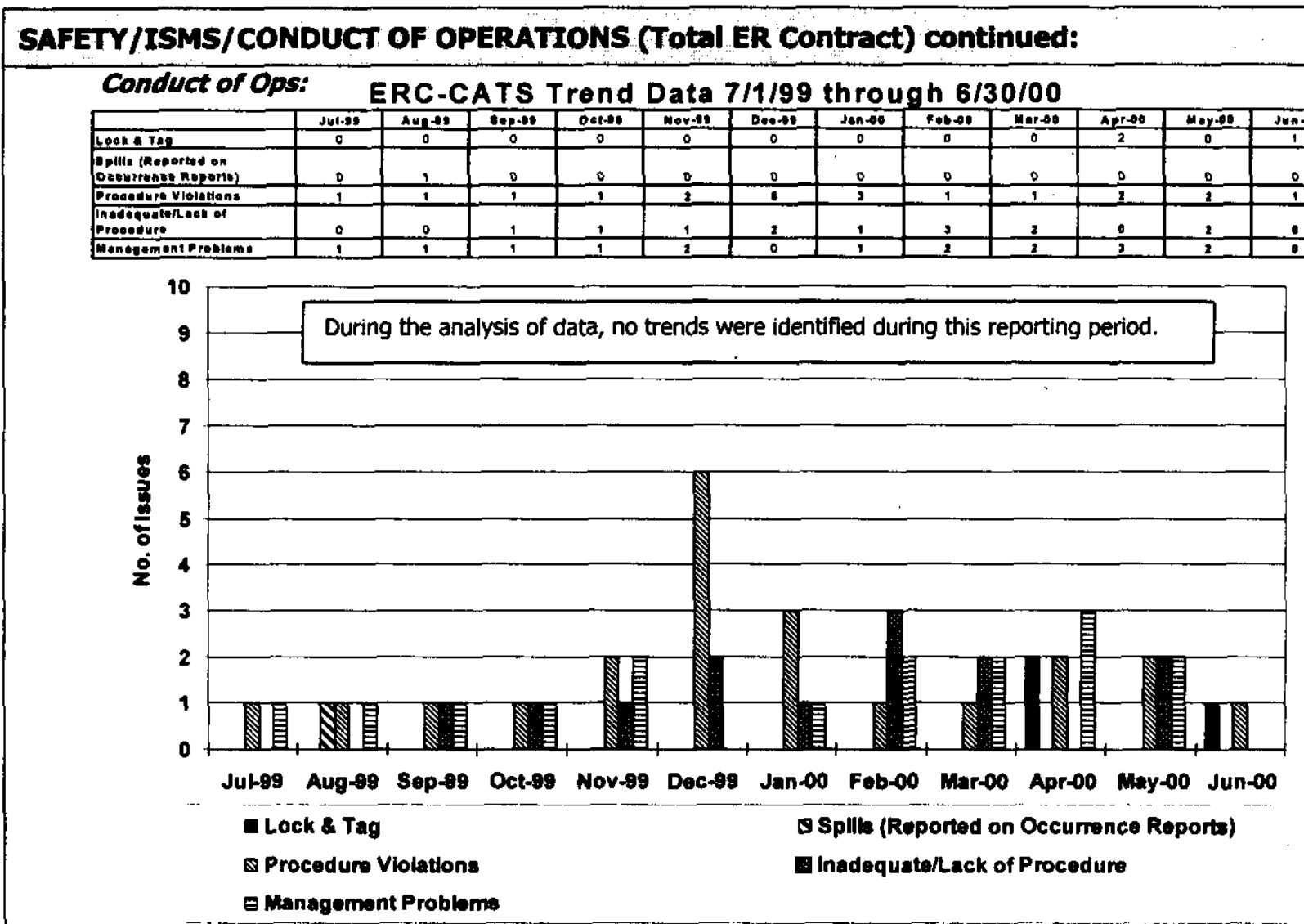

Each potential trend is evaluated for impact on the project, and then given the approprlate level of attention based on a graded approach.

\section{Zune conduct of Ons Kresuer:}

\section{Lock and Tag Issues:}

Condition Description: The facility rep issued a finding which discussed a lack of communication of hazards from the workers to management associated with the 221-U Canyon Crane.

Corrective Action Plan: The above condition was included as a finding in a DOE FR surveillance report (S-00-OOD-ERC-001). As of July 25, BHI is working with $R L$ to verify the facts of the identified conditions prior to determining corrective actions. $B H I$ has requested (and DOE has approved) a 10-day extension in responding formally to this surveillance. The new response date is now August 7.

\section{Procedure Violations:}

Condition Description: A Senior Radiological Control Technician (RCT) in training entered a radiological area/contamination area (RA/CA) to obtain an air sample. The entry was conducted without the appropriate Personal Protective Equipment (PPE) or dosimetry. Although wearing shoe covers and gloves, the appropriate PPE for entry at this time (required by RWP) was one full set of anti-contamination clothing, minus a hood. The appropriate dosimetry for entry into this project includes a PD3 (alarming dosimetry) in addition to a Thermoluminescent dosimeter (TLD). The worker did not have the supplementary PD3 when entering the RA/CA. Entry into the RAVCA as described above is a violation of the Radiological Work Permit (RWP), which is a procedure violation. There was no personal contamination from this incident.

Corrective Action Plan: Functional organization/projects are in process of formulating corrective action. 


\section{ENVIRONMENTAL RESTORATION PERFORMANCE REPORT ENVIRONMENTAL RESTORATION \\ AUGUST 2000}

RECULATORY/EXTERNAL/DOE-RL \& HQ ISSUES AND REQUESTS:

None identified at this time. 


\section{ENVIRONMENTAL RESTORATION PERFORMANCE REPORT ENVIRONMENTAL RESTORATION \\ AUGUST 2000}

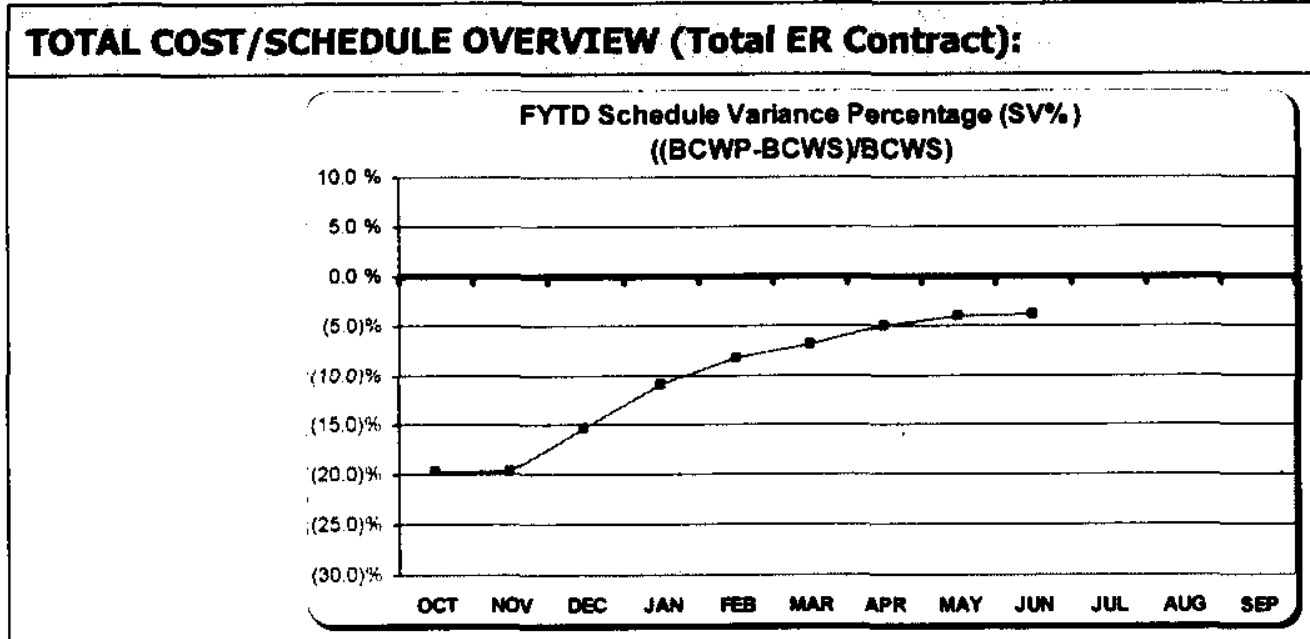

Desired performance is better than $-10 \%$.

\begin{tabular}{|c|c|c|c|c|c|c|c|c|c|c|c|c|}
\hline & oct & nov & DEC & JAN & ras & MAR & APR & MAY & NUN & $2 N_{L}$ & AUG & SEP \\
\hline DWP & 11,612 & 10,506 & 10,211 & 12,760 & 10.155 & 10,793 & 12,259 & 10,599 & 10,197 & 12,389 & 10,820 & 12,798 \\
\hline DWP (Accum) & 11,612 & 22,118 & 32,330 & 45,090 & 55,245 & 66,037 & 78,296 & 88,895 & 99,092 & 111,481 & 122,301 & 135,100 \\
\hline Lews & 14,558 & 8,508 & 12,288 & 15,102 & 13,068 & 13,445 & 15,190 & 12,158 & 12,771 & 14,032 & 11,420 & 17,541 \\
\hline BCWP & 11,711 & 6.838 & 11,396 & 15.035 & 13,338 & $.13,352$ & 15,797 & 12.550 & 12,497 & & & \\
\hline Bews & 14,558 & 23,066 & 35,354 & 50,456 & 63.524 & 76,969 & 92,159 & 104,317 & 117,089 & 131,120 & 142,540 & 160,081 \\
\hline Bcwp & 11,711 & 18,550 & 29,946 & 44,981 & 58,320 & 71,672 & 87,469 & 100,019 & 112,516 & & & \\
\hline sv & $(2,847)$ & $(4,516)$ & $(5,408)$ & $(5,475)$ & $(5,204$ & $(5,297)$ & $(4,690)$ & $(4,690)$ & $(4,573)$ & & & \\
\hline$S v \%$ & $-19.6 \%$ & $-19.6 \%$ & $-15.3 \%$ & $-10.9 \%$ & $-8.2 \%$ & $-6.9 \%$ & $-5.1 \%$ & $-4.1 \%$ & $-3.9 \%$ & & & \\
\hline
\end{tabular}

For variance explanation by PBS, see Project Status Section of each project.

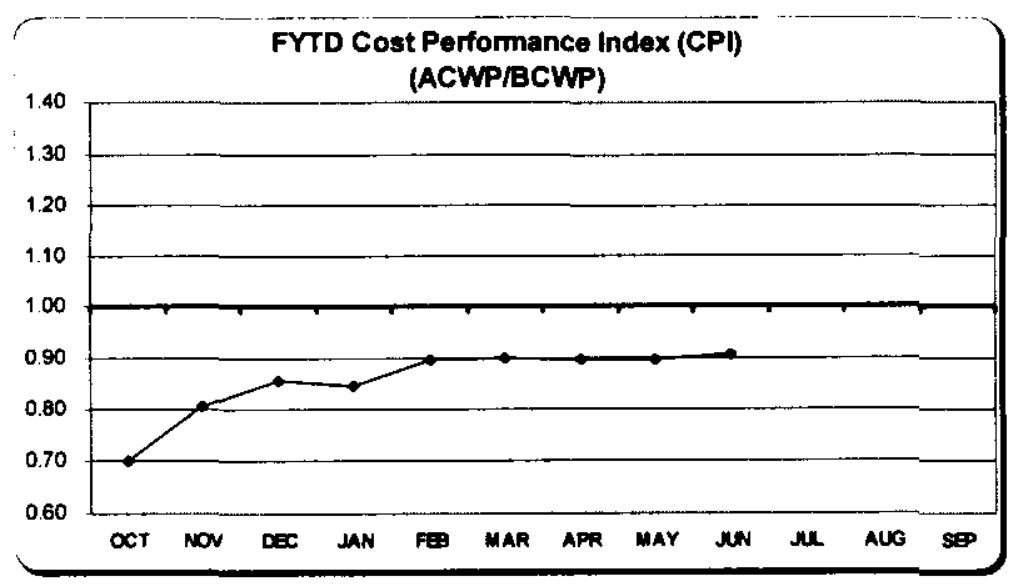

Desired performance is 1.0 or less.

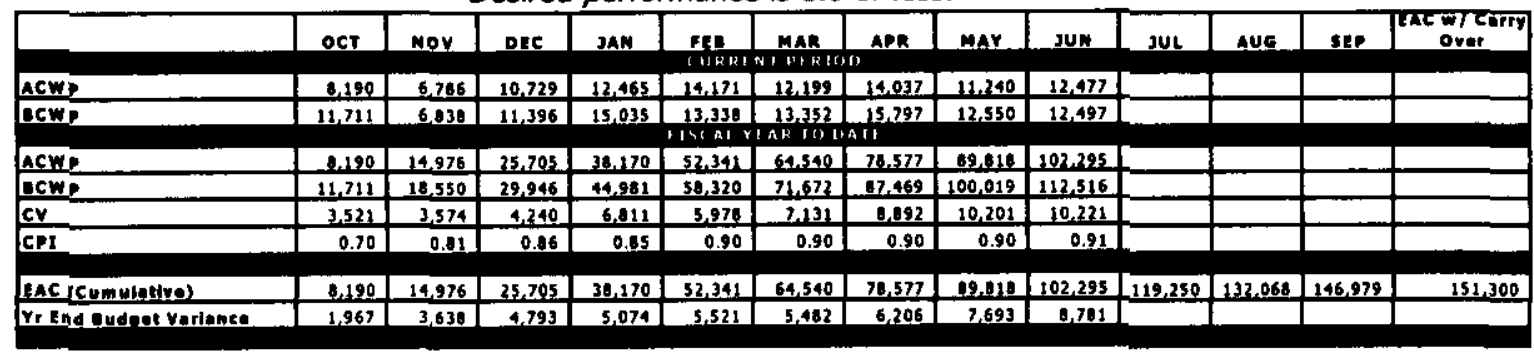

For variance explanation by PBS, see Project Status Section of each project. 


\section{ENVIRONMENTAL RESTORATION PERFORMANCE REPORT ENVIRONMENTAL RESTORATION

\author{
AUGUST 2000
}

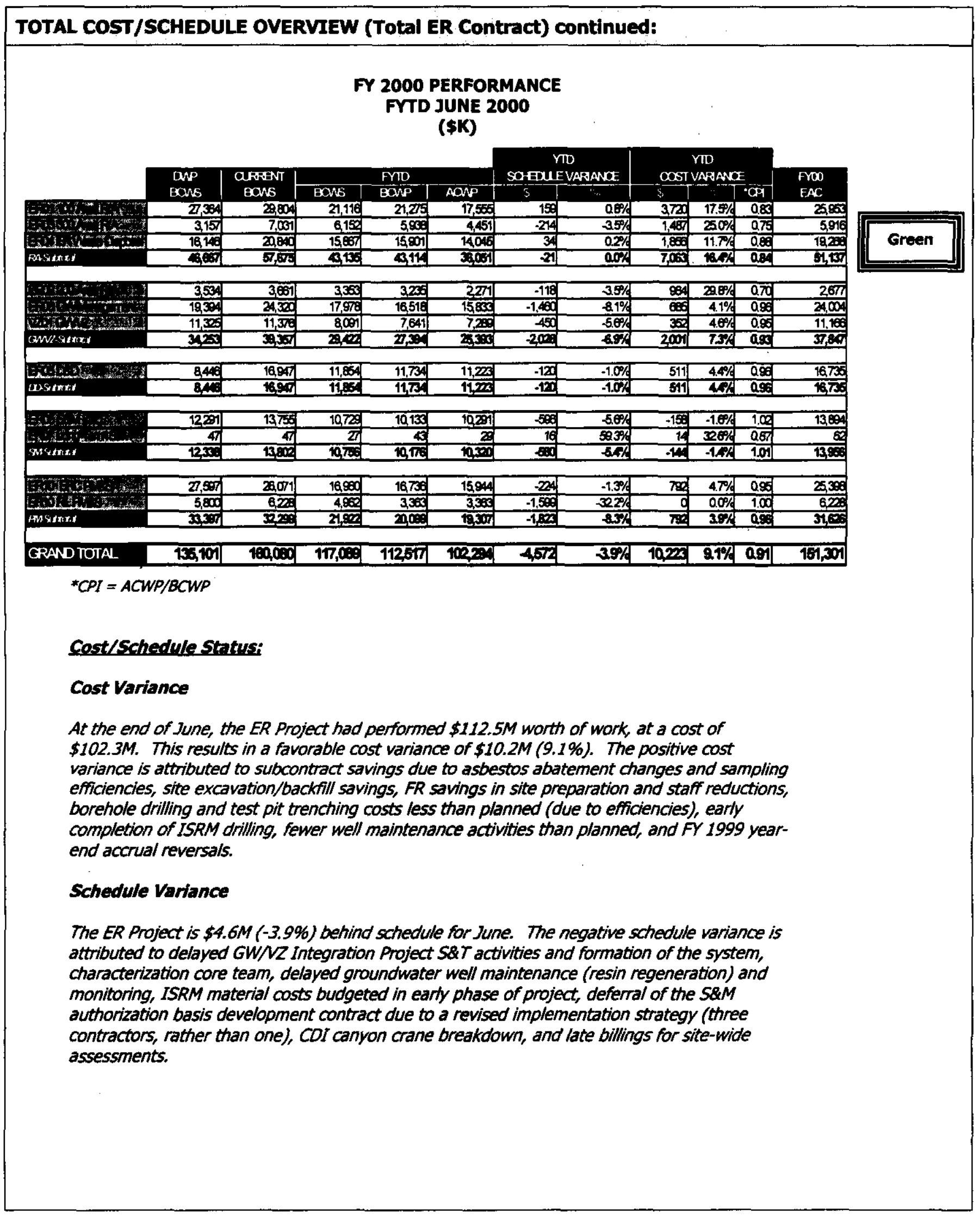




\title{
ENVIRONMENTAL RESTORATION PERFORMANCE REPORT ENVIRONMENTAL RESTORATION \\ AUGUST 2000
}

TOTAL COST/SCHEDULE OVERVIEW (Total ER Contract) continued:

\author{
ER Project Summary \\ FY2000 Funding vs. Forecast Expenditures (EAC)
}

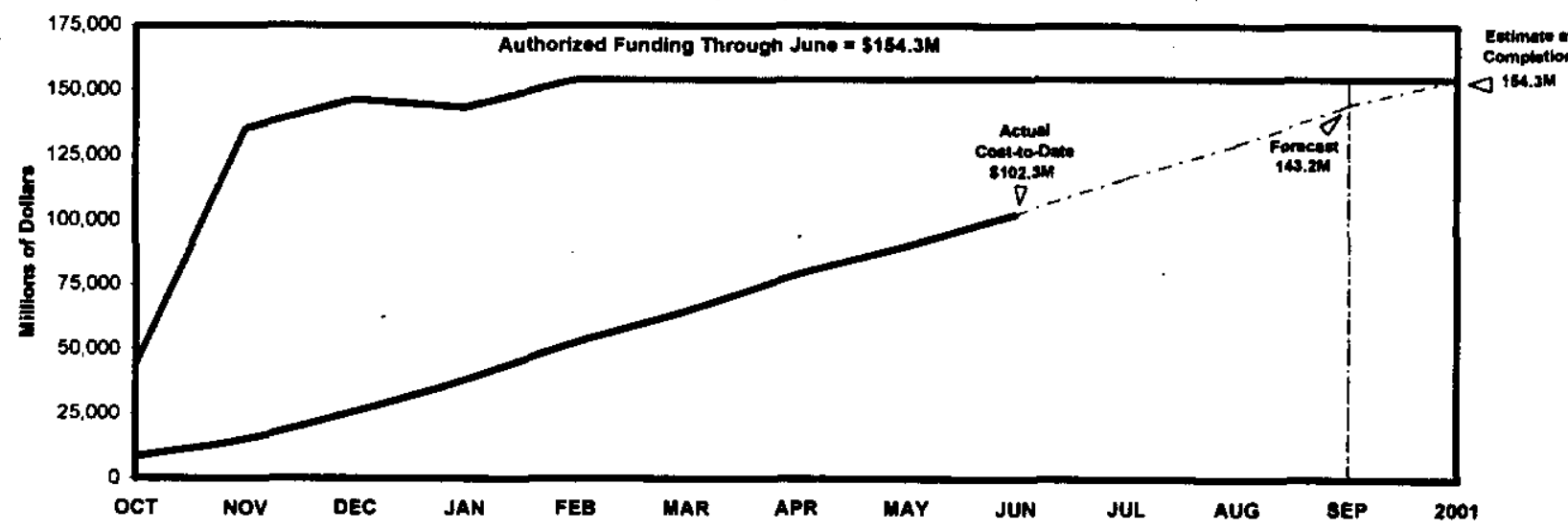

\begin{tabular}{|c|c|c|c|c|c|c|c|c|c|c|c|c|c|c|c|c|c|}
\hline & & & & OCT & NOV & DEC & JaN & FEB & MAR & $A P R$ & mar & UN & JUL & AUG & $\operatorname{sep}$ & 2009 & \\
\hline & AUTHORI & ZZED FU & JNDINE & 43,2003 & 135,220 & 106.223 & 143.2236 & 153.000 & 153.2000 & 150.608 & 153.000 & 154,256 & 154.258 & 156,258 & 154,256 & $\begin{array}{l}\text { sctinowion } \\
\text { Cemponer }\end{array}$ & $\begin{array}{l}\text { EAC } \\
\text { TOTAL }\end{array}$ \\
\hline & APPROV: & ED SCO & & & & & & & & & & & & & & & \\
\hline & Actual Cont & & & 0.180 & 94,076 & 25,705 & 38,170 & 52,341 & Co,540 & 76,577 & 00,818 & 102,205 & & & & & \\
\hline 2 & Cormm non & 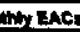 & & 0.100 & 0,700 & 10,720 & 12,405 & 14,171 & 12,180 & 14,037 & 11,241 & 12,477 & 14,165 & 12,407 & 14,000 & & \\
\hline & Cumuletive & EAC & & 8.180 & 14,978 & 25,705 & 30,170 & 52,341 & 0.540 & $7 n, 577$ & 80,818 & 102,205 & 118.400 & 129,297 & 144,187 & 7,104 & 51.301 \\
\hline & EROY & RA & ВCP-20252 & Scheduli in & poncts Do & to June & 000 with & & & & & & 0 & 0 & $(403)$ & 0 & (103) \\
\hline 5 & ER01 & RA & BCP-20243 & Adotitional I & Aeterial 10 & $07 \cdot H-4, A C$ & ditioner PI & met 1000 & Q. Dofor I & xeaveting 1 & 18.F-14 & & 35 & 0 & of & 0 & 35 \\
\hline 6 & ER03 & RA & BCP-20240 & $300-F F-2 P$ & tase 1 of $k$ & d Engines & ing Study & & & & & & 21 & 22 & 10 & 0 & 53 \\
\hline 7 & ER03/04 & RA & BCP-20233 & Reduction & IOunntive & solund & ill $1 \mathrm{~A}, \mathrm{Add}$ & tonal Q 1 & Pand 8 & & & & (273) & 0 & 0 & 0 & (273) \\
\hline B & EROS & SM & BCP-20249 & HReector I & enecy $w_{2}$ & sto Remor & & & & & & & 0 & 0 & 58 & 0 & 56 \\
\hline 9 & ERO5 & SM & BCP-20250 & BRenctor & Tocosents & gerods Mith & tution & & & & & & 0 & 8 & 12 & 493 & 513 \\
\hline 10 & ER06 & 00 & $B C P-20234$ & $233-S A C C$ & orato war & $\mathrm{k}$ Puckeq & Prep, PA & A Panel $R$ & movalf & $m F Y 2001$ & & & 37 & 44 & 34 & 0 & 135 \\
\hline 11 & EROQ110 & PM/GW & BCP-20185 & Columbis $F$ & iver Corric & or Well D. & commissik & $\operatorname{lng}$ (Phan & (1B),Av & ird Foe & & & 0 & 12. & 14 & 1.452 & 1.478 \\
\hline 12 & EROB & GW & BCP. 20240 & Deepen Ele & cted Vedo & es Wolt in & 200-PW-1 & Prop for F & $\pi$ Tosti) & & & & 10 & 30 & 47 & 327 & 414 \\
\hline 13 & EROB & GW & BCP.20246 & Columbian & iver Corric & or (Phase & 1A) Well 0 & commiess & oning & & & & 0 & 28 & 76 & 0 & 104 \\
\hline 14 & ER10 & PM & BCP 20218 & Rediolopice & Countung & Fucility E & vipment $P$ & Icthases & & & & & 0 & 0 & 417 & 0 & 417 \\
\hline 15 & ER10 & PM & $8 C P .20228$ & 10CFR-835 & Redcon $F$ & Toprem Im & glementert & & & & & & 0 & 18 & 21 & 0 & 39 \\
\hline 16 & ER10 & $P M$ & $B C P-20228$ & VPP Onaitt & Evelumitor & Training: & Contracto & VPP APP & cation $A$ & easment & & & 8 & 7 & 8 & 0 & 24 \\
\hline 17 & ER10 & $P M$ & FCP.20253 & Propom M & mit. Sup & port-RL & Scope Rex & ection) & & & & & 0 & $(400)$ & 0 & 0 & $(400)$ \\
\hline 18 & ERto & PM & BCP. 20235 & FY 10040 & site Re- & & & & & & & & 0 & 0 & 80 & 0 & 88 \\
\hline & $\begin{array}{l}\text { ST Approv } \\
\text { Pendinig }\end{array}$ & $\frac{d \text { Scope }}{3 \mathrm{CP}_{\mathrm{S}}}$ & Chenpes & & & & & & & & & & (182) & (231) & 703 & 2,272 & 2,582 \\
\hline 20 & ALL & & Provisional Billin & ORato Adjur & trment Rer & & & & & & & & 0 & $(2,000)$ & (200)] & (100) & $(2,300)$ \\
\hline 21 & ER03 & RA & BCP-20204 & Finel Quant & tien for $s$. & Procossp & & & & & & & 0 & 0 & (178) & 0 & (178) \\
\hline 22 & ER03/04/10 & & $B C P-20173$ & Remaciatio & $800-23$ & A. Jones & at 300-FF. & ERDF C & osts, Por & mance $\mathrm{Fe}$ & & & 0 & 20 & 20 & 1,716 & 1,750 \\
\hline 23. & ERO5 & SM & BCP-20282 & Repair Erot & en Crane & Theol on & anyon $\mathrm{Cr}_{r}$ & & & & & & 0 & 24 & 0 & 0 & 94 \\
\hline 24 & ERO5 & $S M$ & ВCP.20201 & PUREX SE & npio Line & Zopair & & & & & & & 0 & 11 & 14 & 0 & 25 \\
\hline 25 & ERO5 & SM & $B C P-20203$ & 221.U Roor & Repairs & & & & & & & & 0 & 65 & 83 & so & 188 \\
\hline 26 & EROB & $D D$ & ВСР-20247 & Properoro DO & OrSAPfor & Wasti De & signation $f$ & $\mathrm{IDEHR}$ & ectors & & & & 0 & 44 & 0 & 0 & 44 \\
\hline 27 & ERDQ & $D D$ & 233-S Renpe Fir & $(\theta / 2000) R$ & ecoverys & Enedule & & & & & & & 0 & 18 & 20 & 0 & 38 \\
\hline 28 & EROQ & GW & BCP-20251 & GW Menep & mem seg & Delatio & & & & & & & 0 & (341) & 0 & 0 & \{341\}; \\
\hline 29 & ER10 & $P M$ & ECP.20257 & FY $1900 \mathrm{Fir}$ & S Siti Re & bill for $E R$ & & & & & & & (157) & 0 & 0 & 0 & (157) \\
\hline 30 & ER10 & PM & Legal Adjuz:men & & & & & & & & & & 0 & 0 & 1,180 & 0 & 1,198 \\
\hline & Subtotal Jul & $y F Y 200$ & D Approved BCP & P +Pandin & BCP: & & & & & & & & (319) & $(2,322)$ & 1,650 & 3,038 & 2,955 \\
\hline 32 & $\begin{array}{l}\text { Curront Mor } \\
\text { Approved } 1\end{array}$ & $\begin{array}{l}\text { Thly EAC } \\
\text { CPPBSP }\end{array}$ & $\begin{array}{l}\text { C + July FY2000 } \\
\text { onding BCP's: }\end{array}$ & 8,180 &, $\mathrm{ren}$ & 10,727 & 12,460 & 14,171 & 12,19 & 94,037 & 11,241 & 12,477 & 13,240 & 10,016 & 16,6son & 3, & \\
\hline & Apon & ACP'? & & 1,120 & 14,970 & 28,708 & $\mathbf{s t , 1 7 0}$ & 62,341 & Co,840 & 70,677 & 80,018 & 102,205 & 116,149 & $128,6 \mathrm{Gl}^{3}$ & 141,214 & 11,042 & 184,234 \\
\hline
\end{tabular}




\title{
ENVIRONMENTAL RESTORATION PERFORMANCE REPORT ENVIRONMENTAL RESTORATION \\ AUGUST 2000
}

\author{
PERFORMANCE OBJECTIVES: \\ See following individual Project sections.

\section{KEY INTEGRATION ACTIVITIES:} \\ 300 Area Acceleration: BHI supported FH in the development of an accelerated closure \\ plan. \\ Status: The BHI involvement has been completed. The Task Order ended on July 1. \\ $B H I$ has provided the technical volumes for D\&D and Remedial Action. These \\ technical volumes include scope, schedule, cost, and the methodology of the \\ estimating. BHI assisted in the final write-up of the FH deliverable to RL. FH has \\ delivered the final product to DOE-RL and presented the final product to Site \\ Management Board on July 17. Positive comments about the product were made and \\ verbal recognition was given to the FH, BHI and PNNL integrated team.
}

100/600 Area River Corridor Accelerated Restoration Plan: BHI to develop an accelerated restoration plan per $R L$ request.

Status: This study covers scope supporting an accelerated restoration and completion of cleanup scope along the river in support of making the area along the river available for other uses. Preliminary presentation was made to the SMB.

RL WBS/PBS Restructuring: BHI is supporting RL-lead activities to restructure the $R L$ WBS in support of site outcomes, revising the FY 2002 budget submitted and providing a supporting basis for future contracting strategies.

Status: Participating in coordination and strategy sessions with DOE and other contractor personnel; preparing data and studies supporting RL's schedule to have a revised WBS/PBS structure, revise the FY 2002 budget submittal and update the site lifecycle baseline by December 15.

DOE and Bechte/ Staff Recognized for Pollution Prevention Efforts: In late July, U.S. Secretary of Energy Bill Richardson recognized several Department of Energy and Bechtel Hanford, Inc. employees for their waste minimization and pollution prevention accomplishments at Hanford.

Status: The DOE recognition acknowledged BHI's waste minimization and pollution prevention activities over the last several years. Recent accomplishments at Hanford included reducing the amount of waste by more than 300,000 tons and avoiding costs of nearly $\$ 50 \mathrm{M}$ in 1999.

BHI successfully implemented the largest source reduction project in the DOE complex in 1999. It involved extensive characterization of 417 waste sites. As a result, 129 sites were reclassified, enabling BHI to reduce the amount of low-level radioactive waste requiring treatment by nearly 65,000 cubic yards and avoiding costs of more then \$36M.

This single effort reduced more waste than all of the combined source reduction projects implemented throughout the DOE complex in 1998. Source reduction projects reduce pollution or waste generated at this source.

Spent Nuclear Fuel (SNF): The first $K$ Basin waste shipment from the Spent Nuclear Fuel Project was transported to the ERDF on June 26. 


\section{ENVIRONMENTAL RESTORATION PERFORMANCE REPORT ENVIRONMENTAL RESTORATION \\ AUGUST 2000}

\section{UPCOMING PLANNED KEY EVENTS:}

Tri-Party Agreement Milestone M-13-23, Submit 200-TW-1 Workplan, due August 31.

Tri-Party Agreement Milestone M-13-24, Submit 200-TW-2 Workplan, due August 31.

Tri-Party Agreement Milestone M-16-13A, Initiate Remedial Action in the 100-FR-1 Operable Unit, due September 29.

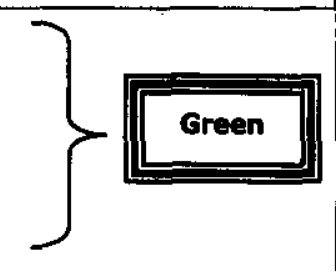




\section{Richland Operations Office Environmental Restoration \\ Environmental Management Performance Report}

\section{Section B - River Corridor Infomllzitioln}

August 2000

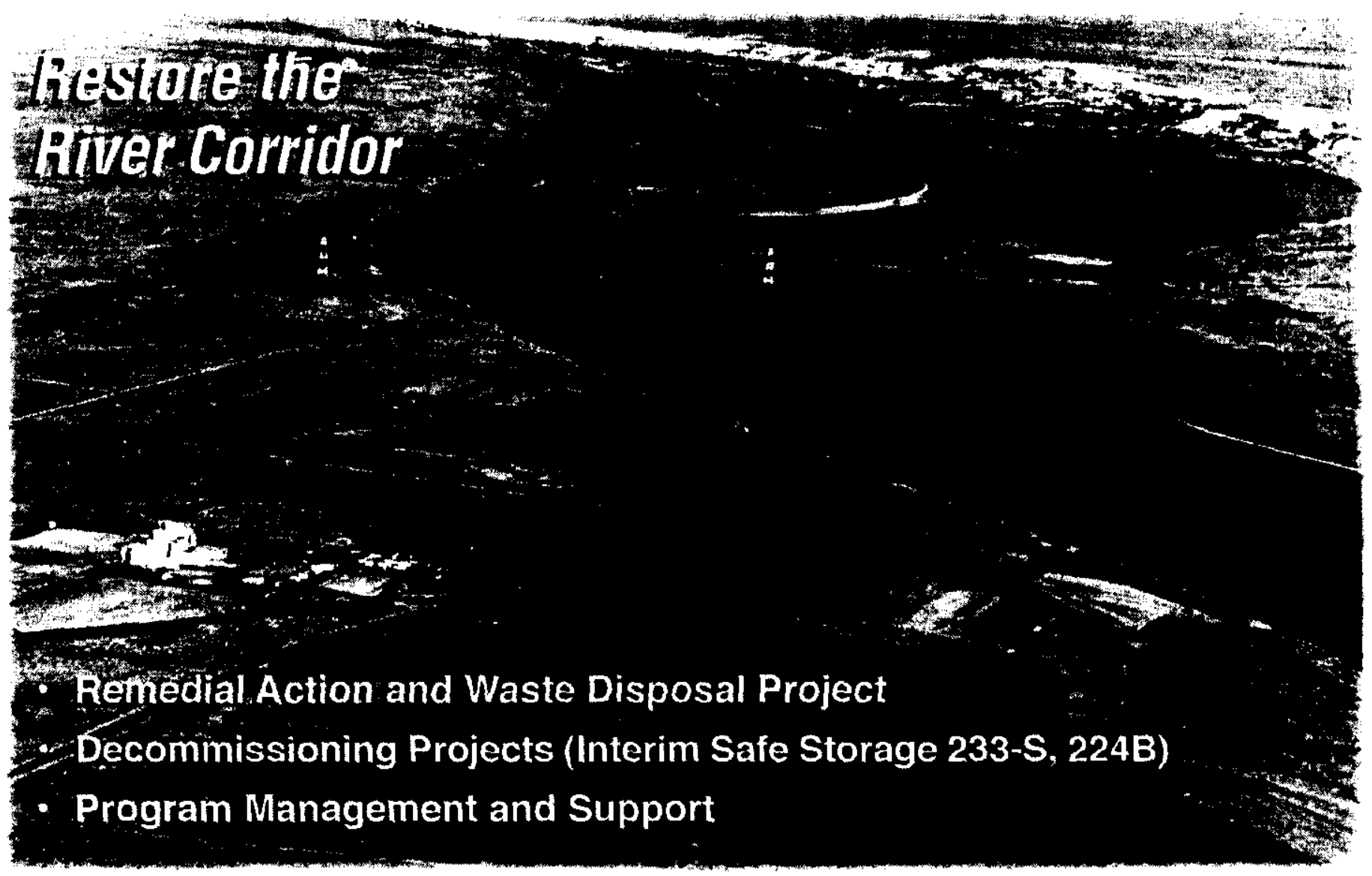

\section{Focused on Progress... Focused on Outcomes!}

Bechtel Hanford, Inc. Environmental Restoration Contractor 


\section{ENVIRONMENTAL MANAGEMENT PERFORMANCE REPORT ENVIRONMENTAL RESTORATION AUGUST 2000}

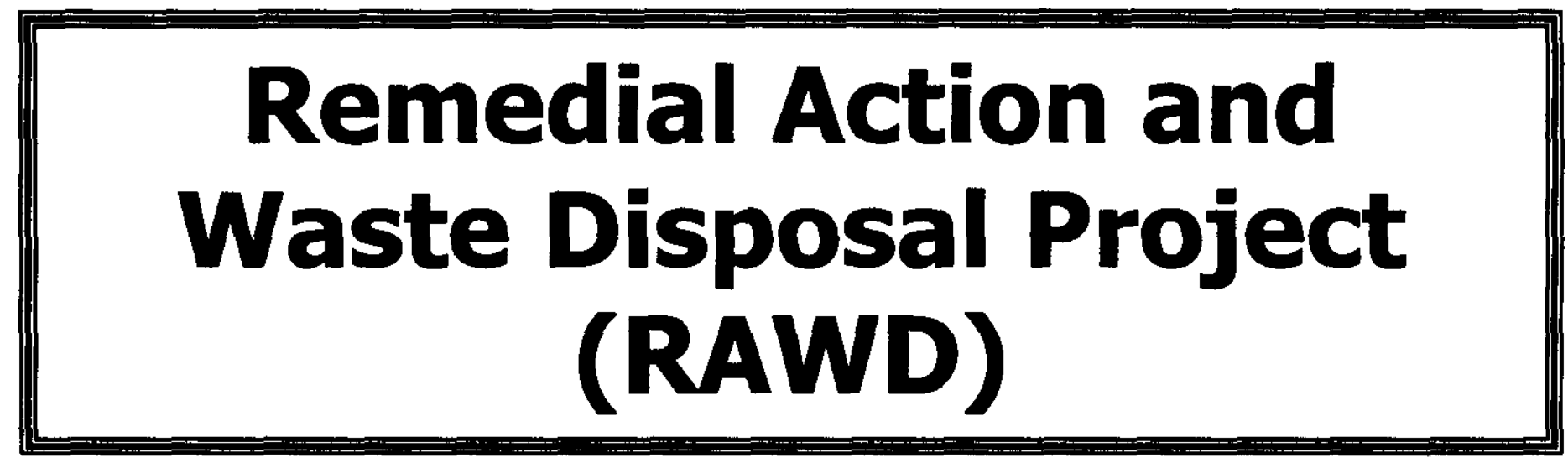




\title{
ENVIRONMENTAL MANAGEMENT PERFORMANCE REPORT ENVIRONMENTAL RESTORATION

\author{
AUGUST 2000
}

\section{SECTION B - RESTORING THE RIVER CORRIDOR}

\author{
Financial / Performance Measures data as of month-end June. \\ All other data as of July 27, 2000 (unless otherwise noted). \\ Remedial Action \& Waste Disposal Project (RAWD):
}

ACCOMPLISHMENTS: RAWD

Environmental Restoration Dispasal Facility (ERDF) Transportation and Operations: On June 7, the first shipment of waste was placed into Cell \#4 at ERDF. Construction of Cells \#3 and \#4 was completed in December 1999 which doubled the capacity of the disposal facility.

The Management of Change (MOC) for EROF Safety Analysis was approved. The MOC addresses the receipt of wastes from the 100-N cribs remediation and the Spent Nuclear Fuel (SNF) K-Basin Project. The hazard classification for ERDF will remain "radiological". The ERDF received the first waste shipment from the SNF Project on June 26.

ERDF operations were curtailed from the morning of June 28 through swing shift of June 30 due to the Hanford Site range fire. Some vegetation within the ERDF fence was burned, but no other damage occurred. Operations resumed without incident on July 3.

During June, shipments totaling 43,533 metric tons (47,988 tons) of contaminated waste were transported to the ERDF. 459,447 metric tons (506,456 tons) have been received in FY 2000 (this is $1 \%$ more than planned). To date, $2,186,423$ metric tons $(2,410,131$ tons) of material have been received and placed in the disposal facility (tonnage on schedule as planned).

100 B/C Area Remediation: Procurement activities are progressing for the $B / C$ pipeline remediation work. A start date for remedial action will be determined during the FY 2001 DWP process development currently underway.

100 D Area Remediation: Fr 2000 pipeline baseline workscope was completed on June 14. Excavation of the approved plume quantities for 116-D-1B and 116-D-1A waste sites was also completed. A BCP was approved to excavate additional contaminated material from the south pipeline trenches. The power pole interfering with the excavation of additional contaminated materials west of 116-D-7 was relocated on June 19. This plume excavation began late June. Backfilling continued at the 116-DR-1 and 116-DR-2 waste sites. Backfilling activities were also initiated at the east/west spurs of the north pipelines and at the 1607-D2 septic tank/associated pipelines remediation.

100 F Area Remedlation: Construction of the 100-FR-1 Operable Unit queue was completed. Access control setup activities were completed, and a self-assessment confirmation readiness was completed. Grubbing and clearing of the pipelines between the retention basin and the river was initiated.

$100 \mathrm{H}$ Area Remediation: Closure verification package sampling began on the H Area pipeline overburden stockpiles. Closure verification package samples were also collected in the 100-H-5 sludge burial pit shallow zone and 116- $\mathrm{H}-1$ disposal trench deep zone.

Overburden removal was completed on the last two sections of 1.5-meter (60-inch) pipe that pass under $H$ Avenue. The concrete encasements on both lines were demolished and debris removed. The asbestos was removed on the northem section of pipe, and then the pipe section was cut into 3-meter (10-foot) lengths. then 


\section{ENVIRONMENTAL MANAGEMENT PERFORMANCE REPORT ENVIRONMENTAL RESTORATION AUGUST 2000}

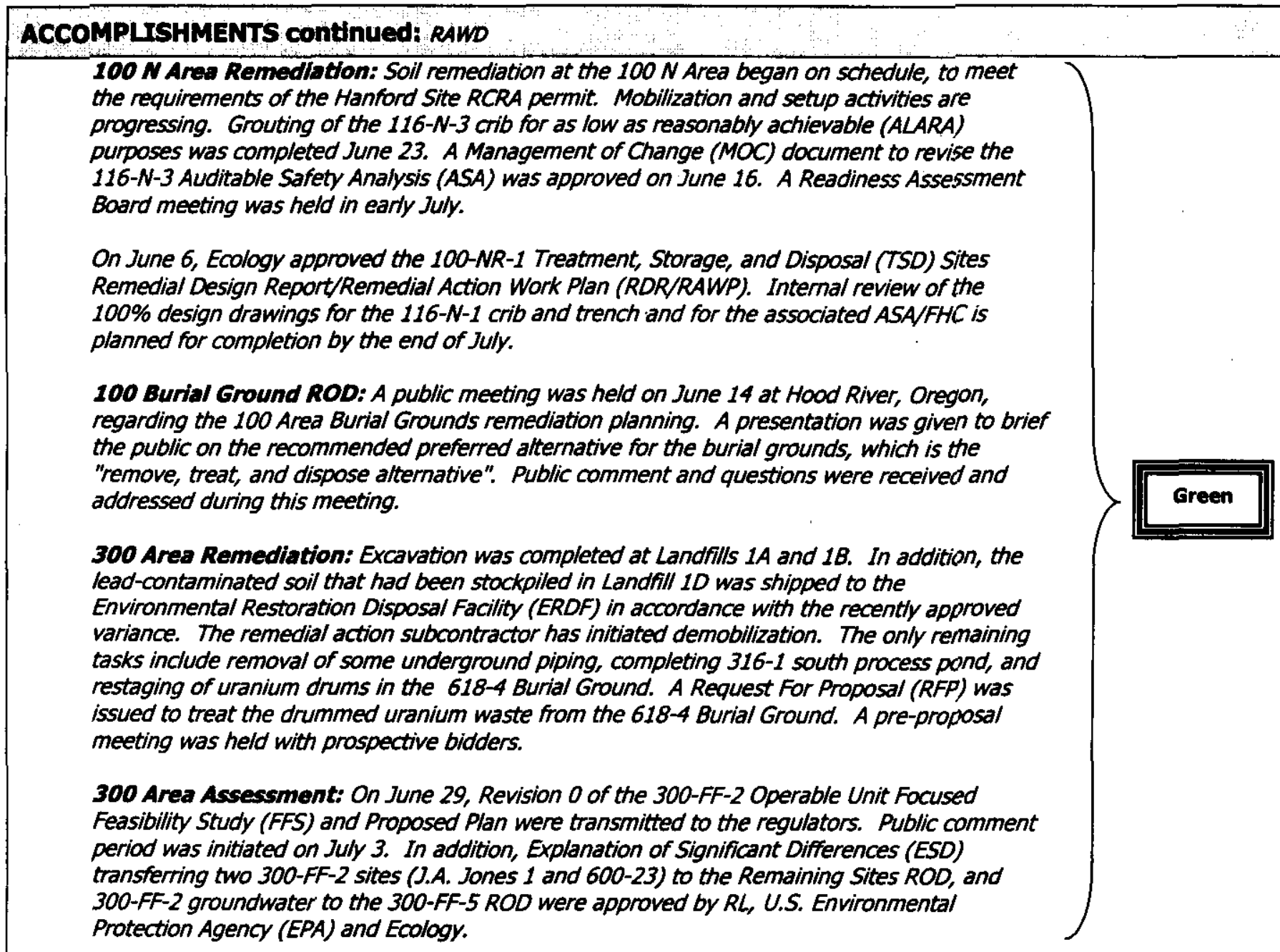

\section{SAFETY/ISMS/CONDUCT OF OPERATIONS: RAWD}

See Executive Summary.

\section{BREAKTHROUGHS/OPPORTUNITIES FOR IMPROVEMENT: RAWD}

Waste Minimization 126-F-1 Ash Pit: The project deployed two off-the-shelf technologies (geo-probe and sodium iodide detector) to perform in-situ characterization that resulted in $50 \%$ reduction in waste site volume. Preliminary cost savings is estimated at \$5M.

Status: Developing plan for site closeout. Project is presently in planning phase of deploying EM-50 funded wireline sampling unit technology to support sampling. Scheduled for August deployment.

\section{LONG-TERM (6 MONTHS PLUS) IMPORTANT ITEMS: RAWD}

100 Area Burtal Grounds: Approval of the Record of Decision (ROD) is planned for September.

Status: Public comment period has been completed. Comments to be incorporated into Proposed Plan and Focused Feasibility Study. Currently tracking on schedule to support September 30 approval of ROD. 


\section{ENVIRONMENTAL MANAGEMENT PERFORMANCE REPORT \\ ENVIRONMENTAL RESTORATION \\ AUGUST 2000}

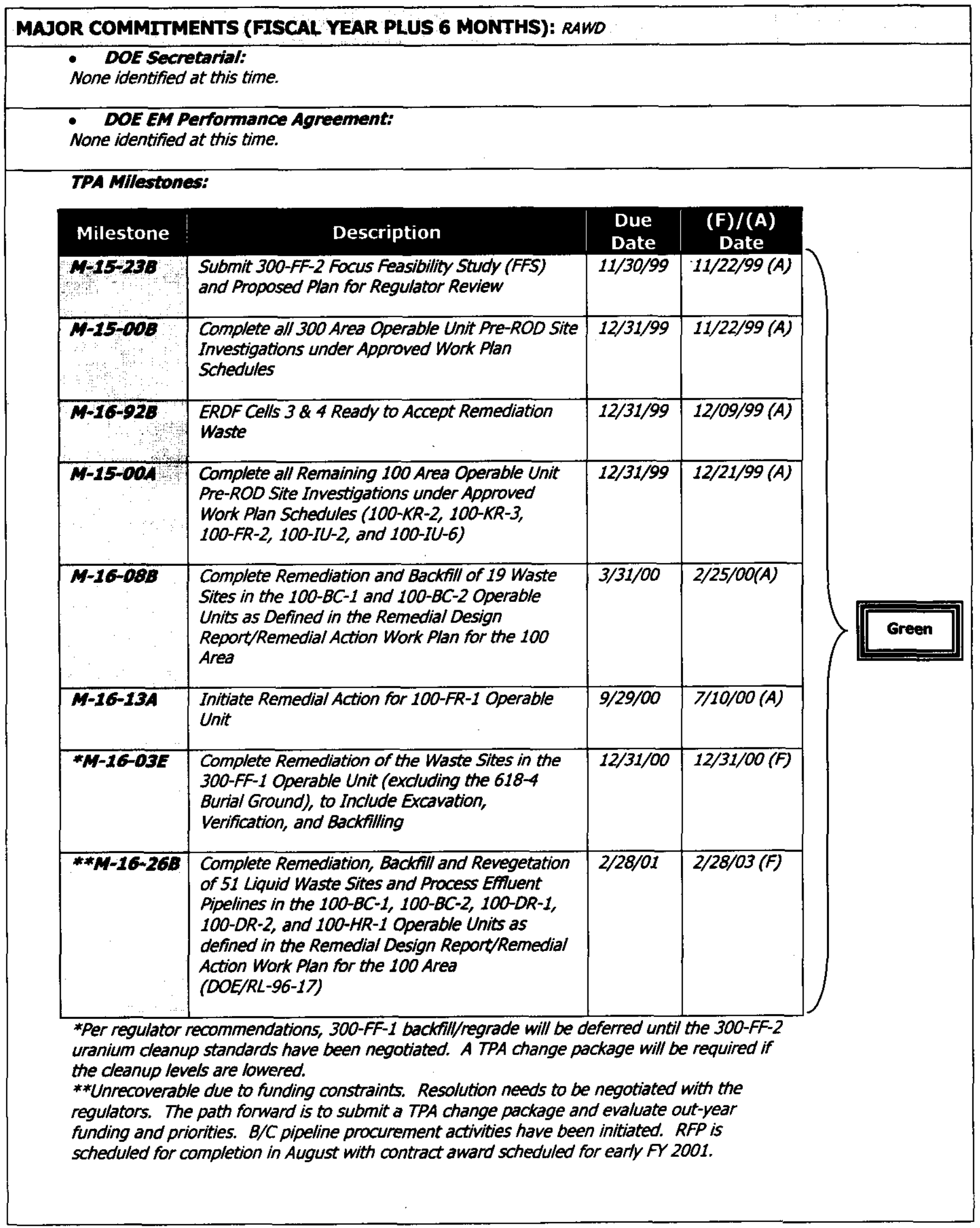




\section{ENVIRONMENTAL MANAGEMENT PERFORMANCE REPORT ENVIRONMENTAL RESTORATION

\author{
AUGUST 2000
}

\begin{tabular}{|c|c|c|}
\hline $\begin{array}{l}\text { DNFSB Commitment: } \\
\text { None identified at this time. }\end{array}$ & & \\
\hline \multicolumn{3}{|c|}{ PERFORMANCE OBJECTIVES: RAWD } \\
\hline Outcome & Performance Indicator & Status \\
\hline $\begin{array}{l}\text { Restore the Rher } \\
\text { Corridor for Mutiple Usw }\end{array}$ & $\begin{array}{l}\text { 100/300 Area waste } \\
\text { excavation, disposal and } \\
\text { backfill/regrade. }\end{array}$ & $\begin{array}{l}\text { Baseline work is projected to } \\
\text { be completed per PI } \\
\text { requirements. }\end{array}$ \\
\hline
\end{tabular}

PERFORMANCE MEASURES: RAWD - (Rver and Plateau)

\begin{tabular}{|c|c|c|c|c|c|}
\hline & $\begin{array}{l}\text { DWP } \\
\text { FYOO }\end{array}$ & $\begin{array}{l}\text { FYo0 Mgmt } \\
\text { Commitments }\end{array}$ & $\begin{array}{l}\text { Current Baseline } \\
\text { (Incl. Baseline } \\
\text { Changes) }\end{array}$ & $\begin{array}{l}\text { Forecast } \\
\text { For } \\
\text { Fyo0 }\end{array}$ & $\begin{array}{l}\text { Completed } \\
\text { YTD }\end{array}$ \\
\hline Waste Sites & 24 & 41 & 42 & 42 & $20^{b}$ \\
\hline $\begin{array}{l}100 \text { Area } \\
\text { Burlal Ground } \\
\text { Acsecssments }\end{array}$ & 0 & 46 & 47 & 47 & $47^{\circ}$ \\
\hline $\begin{array}{l}300-F F-2 \\
\text { Ascessments }\end{array}$ & 119 & 119 & 119 & 119 & $119^{\circ}$ \\
\hline $\begin{array}{l}\text { Other } \\
\text { Assessments }\end{array}$ & 2 & 2 & 2 & 2 & 2 \\
\hline Tons & $389 K$ & $N / A$ & $651 K$ & $651 K$ & $506 K$ \\
\hline
\end{tabular}




\section{ENVIRONMENTAL MANAGEMENT PERFORMANCE REPORT ENVIRONMENTAL RESTORATION \\ AUGUST 2000}

\section{STRETCH AND SUPERSTRETCH GOALS, RAWD}

\begin{tabular}{|c|c|c|}
\hline FYO0 RAWD "Stretch" Goals & $\begin{array}{c}\text { Scope } \\
\text { Dollars }(K)\end{array}$ & $\begin{array}{l}\text { Approved } \\
\text { BCPs (K) }\end{array}$ \\
\hline 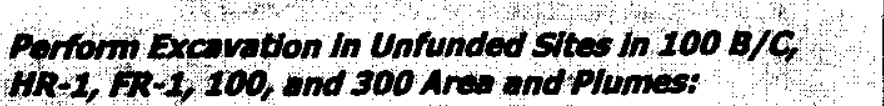 & & \\
\hline (4) Extended Plumes at $316-1 \mathrm{~s}$ Pond (BCP-20043) & & $\$ 1,202.8 \mathrm{~K}$ \\
\hline (2) Addtolon / plumas at 100-DR (BCP-20050) & & $\$ 905.8 K$ \\
\hline (3) Addtional Plumes at 100-HR (BCp-20119) & & $\$ 240.3 K$ \\
\hline (A) Addtond plumes at 100-HR (BCP-20130) & & $\$ 425.0 K$ \\
\hline 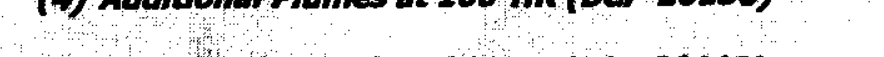 & & \\
\hline (5) Additional Plumes at 300-FF (BCP-20113) & & $\$ 669.4 K$ \\
\hline (6) Addiutonal Plumes at 100-DR (BCP-20116) & & $\$ 175.2 K$ \\
\hline (C) Dotor Bachill at 100-DR (BCP-20166) & & $(\$ 93.2 K)$ \\
\hline (8) Additonal Plumes at 100-DR (BCP-20189) & & $\$ 124.9 K$ \\
\hline (9) Addfitonal Plumes at 100-DR (BCP-20215) & & $\$ 101.1 K$ \\
\hline S/Total Remedial Action Stretch Goals: & $\$ 4,560.0 K$ & $\$ 3,751.2 K$ \\
\hline
\end{tabular}

\begin{tabular}{|c|c|c|}
\hline FYOO RAWD "Superstretch" Goals & $\begin{array}{c}\text { Scope } \\
\text { Dollars (K) }\end{array}$ & $\begin{array}{l}\text { Approved } \\
\text { BCPs (K) }\end{array}$ \\
\hline $\begin{array}{l}\text { Complete Remediation of } 60 \text { Sq. MI. of Hanfond Site: } \\
\text { (1) Complete Remediation of Hanford Townslte }\end{array}$ & $\$ 755.0 \mathrm{~K}$ & $\$ 0.0 K$ \\
\hline 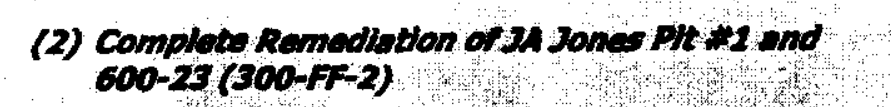 & $\$ 1,500.0 K$ & $\$ 0.0 K$ \\
\hline (3) Other RemedialActions & $\$ 1,395.0 K$ & $\$ 0.0 K$ \\
\hline S/Total Remedial Action Superstretch Goals: & $\$ 3,650.0 \mathrm{~K}$ & $\$ 0.0 K$ \\
\hline
\end{tabular}

*Status: Efficiencies identified; project working on baseline change package. 


\section{ENVIRONMENTAL MANAGEMENT PERFORMANCE REPORT ENVIRONMENTAL RESTORATION \\ AUGUST 2000}

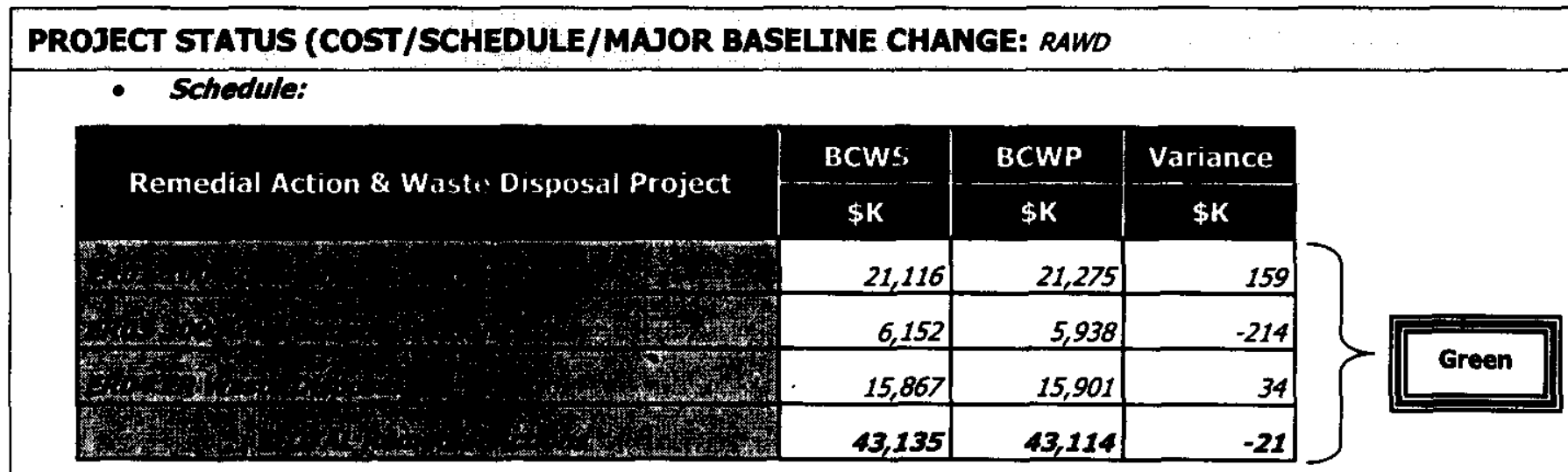

PBS-ERO1 - 100 Area Remedial Action

Schedule Variance $=+\$ 159 \% ;+0.8 \%$ [Last Month: $+\$ 353 ;+1.9 \%$ ]

Cause: Ahead of schedule on NR-1 crib remediation design and site prep and 100-HR excavations.

Resolution: None required.

PBS-ERO3 - 300 Area Remedial Action

Schedule Variance $=-\$ 214 ;-3.5 \%$ [Last Month: $+\$ 16 K ;+0.3 \%$ ]

Cause: Procurement Package for Drum Disposal is behind schedule due to additional bid time requested by the bidders. Landfill 10 soil loadout delayed due to variance and waste profile issue.

Resolution: None required.

PBS-ERO4 - Environmental Restoration Waste Dispasal

Schedule Variance $=\$ \$ 34 \% ;+0.2 \%$ [Last Month: $+\$ 471 K ;+3.4 \%$ ]

Cause: Design and installation of cover (closure) being ahead of schedule.

Resolution: None required.

\section{- Cost:}

\begin{tabular}{|c|c|c|c|c|}
\hline \multirow{2}{*}{ Remedial Action \& Waste Disposal Project } & BCWP & ACWP & Variance & \\
\hline & $\$ \mathbf{K}$ & $\$ \mathbf{K}$ & $\$ \mathbf{K}$ & \\
\hline 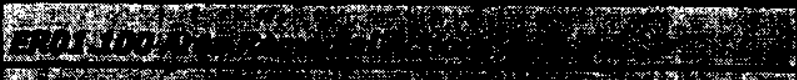 & 21,275 & 17,555 & 3,720 & \\
\hline 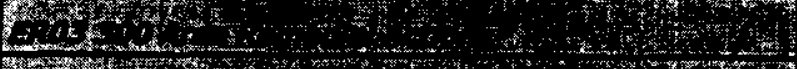 & 5,938 & 4,451 & 1,487 & Grana \\
\hline 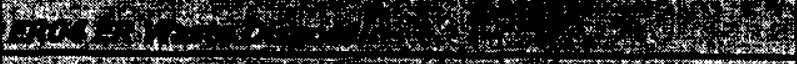 & 15,901 & 14,045 & 1,856 & Lreen \\
\hline 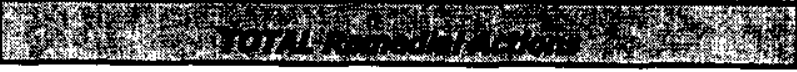 & 43,114 & 36,051 & 7,063 & \\
\hline
\end{tabular}

\section{PBS-ERO1 - 100 Area Remedial Action}

Cost Variance $=+\$ 3720 K ;+17.5 \%$ [Last Month: $+\$ 4044 K ;+21.2 \%$ ]

Cause: Savings in DR-1 subcontract costs due to asbestos abatement changes and sampling efficiencies; FR savings in site prep and staff reductions by re-allocating forces between $F \& H$ areas; labor savings on B/C backfill activities; waste minimization and drilling savings at $H R$ near-river excavation sites. 


\section{ENVIRONMENTAL MANAGEMENT PERFORMANCE REPORT ENVIRONMENTAL RESTORATION \\ AUGUST 2000}

PROJECT STATUS (COST/SCHEDULE/MAJOR BASELINE CHANGE continued: RAWD

Resolution: Savings will be used to perform other remediation work.

PBS-ER03 - 300 Area Remedial Action

Cost Variance $=+\$ 1487 K ;+25.0 \%$ [Last Month: $+\$ 1745 \% ;+31.3 \%$ ]

Cause: Management and administrative cost efficiencies at Landfills $1 A / 1 B$, and

FY 1999 accrual reversal in South Process Pond remediation.

Resolution: Savings will be used to perform other remediation work.

PBS-ERO4 - Environmental Restoration Waste Disposal

Cost Variance $=[+\$ 1856 K ;+11.7 \%]$ [Last Month: $+\$ 1868 K ;+12.9 \%]$

Cause: ERDF cover design and construction closeout completed with fewer resources than planned, transportation cost efficiencies, and FY 1999 over accrual.

Resolution: Savings will be used to perform other remediation work.

\section{REGULATORY ISSUES: RAWD}

Tri-Party Agreement Mllestone M-16-26B: An out-year milestone, M-16-26B, "Complete Remediation and Backfill of 51 Waste Sites at $B / C, D R$, and $H R$, by February 28, 2001, "will be missed due to lack of funding for the $B / C$ pipeline remediation.

Status: Revised dates will be negotiated with the regulators, and a Tri-Party Agreement change package will be submitted. A meeting will be scheduled with the regulators in August.

Tri-Party Agreement Milestone M-16-26C: M-16-26C, "Complete Remediation and Backfill of 10 Liquid Waste Sites in the 100-HR-1 Operable Unit, by May 31, 2001," will be missed due to unanticipated elevated arsenic levels encountered during confirmation sampling and verification activities.

Status: After completing additional arsenic sampling throughout the 100 Areas, Ecology agreed to use the Washington state background value of $20 \mathrm{mg} / \mathrm{kg}$ for arsenic. A BCP was approved that addressed this scope change. A Tri-Party Agreement change package will be initiated after the final plume remediation is completed.

Tri-Party Agreement Milestone M-16-03E: Regulators are evaluating the uranium cleanup level for the 300 Area. The approved 300-FF-1 ROD requires residual soil to be below 350 $\rho C l / g$, based on direct human contact. Currently lower cleanup levels are being explored for protection of groundwater at 300-FF-2. If lower cleanup levels are determined to be appropriate for 300-FF-1, additional excavation will be necessary. Tri-Party Agreement Milestone M-16-03E, "Complete Remediation of Waste Sites in 300-FF-1 Operable Unit (excluding the 618-4 Burial Ground) to Include Excavation, Verification, and Backfilling, is to be completed by December 31, 2000.

Status: Per regulator recommendation, defer backfill/regrade of 300-FF-1 until 300-FF-2 negotiations are completed, and the uranium cleanup standard is finalized. This will require renegotiation of $M-16-03 E$. 


\title{
ENVIRONMENTAL MANAGEMENT PERFORMANCE REPORT ENVIRONMENTAL RESTORATION \\ AUGUST 2000
}

\begin{abstract}
REGULATORY ISSUES ContinUEd: RAWD
300 Area Continued Remediation: The regulators raised a concern that remediation of the 300 Area will not continue through the next fiscal year.

Status: A meeting was held with the regulators on July 26 outlining the activities that constitute continuous remediation within the 300 Area that are currently scoped within the FY 2001 DWP. A letter documenting the meeting will be issued the end of July.
\end{abstract}

EXTERNAL ISSUES (1.e. HAB, Congress, etc.): RAWD None identified at this time.

\section{DOE-RL \& HQ ISSUES/REQUESTS (not covered elsewhere): RAWD}

None identified at this time.

\section{INTEGRATION ACTIVITIES: RAWD}

ERDF: In support of Hanford Site partnering, draft waste shipping and receiving plans (WSRPS) have been prepared for the two initial waste streams expected from the Spent Nuclear Fuel (SNF) Project's K Basin clean out work. Initial delivery of waste from the SNF began on June 26. 


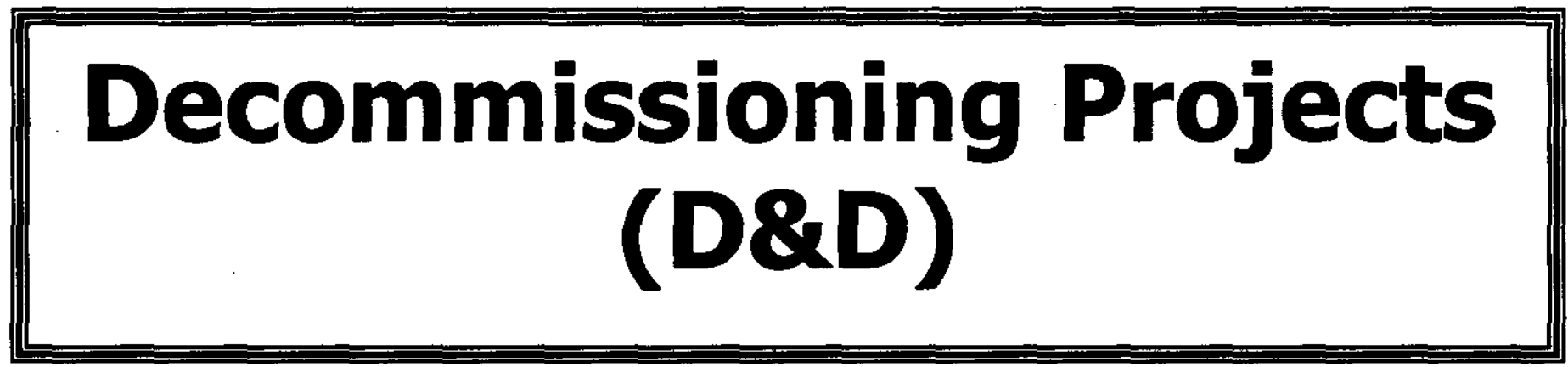




\title{
ENVIRONMENTAL MANAGEMENT PERFORMANCE REPORT ENVIRONMENTAL RESTORATION \\ AUGUST 2000
}

\section{SECTION B - RESTORING THE RIVER CORRIDOR}

\author{
Financial / Performance Measures data as of month-end June. \\ All other data as of July 27, 2000 (unless otherwise noted). \\ Decommissioning Projects (D\&D)
}

\section{ACCOMPLISHMENTS, DOD}

$F$ and DR Reactor ISS: Steady progress continued at the $F$ and DR Reactor ISS projects during June. Backfill was completed in the below-grade gas recirculation tunnel and plenum demolition areas at $F$ Reactor. A combined (Stage I and II) F Reactor (FSB) Sampling Analysis Plan (SAP) was issued for review and comment. The FSB water removal plan and the fuel transfer plan are nearing completion. Removal of exterior building debris began on the east side of the reactor in late June. The $F$ Reactor Hazards Assessment and Characterization Report was transmitted to EPA on June 19. This satisfies completion of Tri-Party Agreement Target Milestone M-93-08-T1 that was due on June 30.

At the DR Reactor, concrete pourbacks were completed in the below-grade valve pit, accumulator trench, north gas tunnel area, and south gas recirculation tunnel. At a May 17 meeting held with the regulators, agreement was reached that the contaminant concentrations in the DR Reactor FSB concrete were low enough and sufficiently immobile to allow the FSB floor slab to remain in place. These meeting results were documented and approved by the regulators in June. Demolition of the FSB (above-grade and below-grade), transfer bay, and monitor room was completed the last week in June.

$D$ and $H$ Reactor ISS: Biological cleanup was initiated at H Reactor in June. The Draft $B$ EE/CA documents for $D$ and $H$ Reactor ISS were submitted for $R L$ and regulator review. The $H$ Reactor ASA was transmitted to RL on June 30. The D Reactor ASA comment resolution was also completed in June. The gamma camera and In Situ Object Characterization Survey (ISOCS) instrumentation were deployed at D Reactor for radiological scoping surveys.

233-S P/utonium Concentration Facility Decommissioning Project: Work progressed at the highly contaminated 233-S Plutonium Concentration Facility Decommissioning Project in June, including the following activities:

- Completion of radiological surveys of the process hood floor area.

- Removal of PMMA panels (total 70) from the process hood east face has been completed ahead of schedule. Continued removal of horizontal channel iron.

- Completion of the first fixative application in the process hood.

- Neutralized and stabilized 12 liters of nitric acid.

- Removal of supply duct inside the viewing room fourth floor stairwell.

- Removal of grating from the north ends of viewing room second, third, and fourth floors in preparation for localized ventilation installation. 


\section{ENVIRONMENTAL MANAGEMENT PERFORMANCE REPORT ENVIRONMENTAL RESTORATION

\author{
AUGUST 2000
}

\begin{tabular}{|c|c|c|}
\hline \multicolumn{2}{|c|}{$\begin{array}{l}\text { SAFETY/ISMS/CONDUCT OF OPERATIONS: DQD } \\
\begin{array}{l}\text { Contamination detected under manufactured be/t loops of Powered Air Purifying Respirators } \\
\text { (PAPR). }\end{array}\end{array}$} & Green \\
\hline & $\begin{array}{l}\text { Status: The ERC has completed the formal causal analysis of the PAPR contamination } \\
\text { and procedural noncompliance issues. The corrective actions resulting from the } \\
\text { analysis are: } \\
\text { Corrective Action \#1 - The ERC will evaluate the current method for releasing PAPR } \\
\text { units from a controlled area. This evaluation will also include other radiological safety } \\
\text { equipment such as air monitors, air samplers, and the potential use of Radioactive } \\
\text { Material labeling. } \\
\text { Corrective Action \#2 - The PAPR procedure will be revised to require formal training } \\
\text { to DeD workers tasked with taping a manufacturer's supplied plastic cover on PAPR } \\
\text { units for contamination control. This will standardize the method in which PAPR units } \\
\text { are taped and provide appropriate review of methodology by affected organizations. } \\
\text { Corrective Action \#3 - The ERC will evaluate and revise its required reading program } \\
\text { as appropriate. Current recommendations include setting a review time for Training } \\
\text { Coordinators to check for procedure revisions, set a reasonable time for employees to } \\
\text { complete required reading, establish a requirement and process for procedure authors } \\
\text { to notify managers and Training Coordinators of procedure revisions, and establish } \\
\text { priority levels which will establish time limits for required reading of work process and } \\
\text { safety related procedure changes. } \\
\text { Corrective Action \#4 - The requirement to build a temporary belt loop from duct tape } \\
\text { will be removed from the PAPR procedure. The NIOSH approved equipment } \\
\text { (manufacturer's belt loop) will be used with modifications to the taping methodology } \\
\text { to eliminate contamination potential. In addition, the ERC has reinstated the practice } \\
\text { of wearing the PAPR under the outer layer of protective clothing based on discussions } \\
\text { with the manufacturer and field testing of air flows. Procedure revisions will be } \\
\text { complete by July } 31 \text {. }\end{array}$ & \\
\hline \multicolumn{3}{|c|}{ BREAKTHROUGHS/OPPORTUNITIES FOR IMPROVEMENT: D\&D } \\
\hline \multicolumn{3}{|c|}{ None identified at this time. } \\
\hline \multicolumn{3}{|c|}{ LONG-TERM (6 MONTHS PLUS) IMPORTANT ITEMS: DQD } \\
\hline \multicolumn{3}{|c|}{ None identified at this time. } \\
\hline \multicolumn{3}{|c|}{ MAJOR COMMTTMENTS (FISCAL YEAR PLUS 6 MONTHS): DQD } \\
\hline \multicolumn{3}{|c|}{$\begin{array}{l}\text { DOE Secretarial: } \\
\text { None identified at this time. }\end{array}$} \\
\hline $\begin{array}{l}\text { DOL } \\
224 B: C \\
\text { July } 2000\end{array}$ & $\begin{array}{l}\text { EM Performance Agreement: } \\
\text { omplete draft Engineering evaluation/cost ana/ysis (EE/CA) and submit to regulators - } \\
\text { D. Complete draft SAP and submit to regulators - September } 2000 \text {. } \\
\text { Status: Assessment activities in } 224 B \text { in support of decommissioning have ceased. A } \\
\text { BCP to close out the remainder of the } 224 B \text { activities in FY } 2000 \text { has been approved. } \\
\text { The PI has been updated to eliminate this item. }\end{array}$ & Green \\
\hline
\end{tabular}




\title{
ENVIRONMENTAL MANAGEMENT PERFORMANCE REPORT ENVIRONMENTAL RESTORATION AUGUST 2000
}

\begin{tabular}{l} 
(5) MAJOR COMMITMENTS (FISCAL YEAR PLUS 6 MONTHS) continued: D\&D \\
\hline \begin{tabular}{|c|c|c|c|}
\hline TPA MIllestones: & Due Date & $\begin{array}{c}\text { (F)/(A) } \\
\text { Date }\end{array}$ \\
\hline Milestone & Description & $7 / 10 / 00(A)$ \\
\hline M-93-05 & $\begin{array}{l}\text { Issue B Reactor Phase II Feasibility Study } \\
\text { Engineering Design Report for Public Comment }\end{array}$ & $6 / 30 / 00$ \\
\hline
\end{tabular}
\end{tabular}

*The B Reactor milestone deliverable was submitted to DOE-RL (PM) on June 27 and delivered to the DOE-RL Office of Regulatory Liaison on June 28 for concurrence and submittal through the remainder of the signature cycle. The document was received by the regulators on July 10, ten days later than the milestone completion date of June 30. A letter received on July 25 documented comments on the content of the document.

\begin{abstract}
Status: $A$ follow-up meeting with the regulators is scheduled for July 27 to discuss a path forward for completion of the EE/CA. EPA states that the milestone will be considered complete upon receipt of a response from DOE-RL committing to a schedule of our EE/CA for B Reactor. The response letter should also address what the EE/CA will cover in relation to the concerns raised in the EPA comment letter. The draft letter is currently being prepared. The EE/CA scope of work is waiting approval by DOE-AME and is scheduled to start in September 2000.
\end{abstract}

Chronology of Events: Meetings were held with EPA and Ecology to discuss changes related to the reactor TPA milestones in general due to the accelerated ISS Project. These meetings began in late March and are continuing. The scope of the $B$ Reactor milestones were discussed at the earlier meetings. It was noted that the complete path forward for B Reactor had not been developed in prior negotiations. The scope of the June 30, 2000 milestone (M-93-05) was described by DOE as an engineering and cost evaluation for addressing the hazards identified in the June 30, 1999 milestone (M-93-04) along the existing tour route. This scope was defined in the DWP. EPA expressed concern that the document would not be sufficient for public review and should include all the hazards for the facility not just the existing tour route. EPA suggested that DOE continue with the path to meet the milestone and include a rough order of magnitude estimate for the remaining hazards in the facility outside the existing tour route. BHI and DOE approved BCP 20199 in May 2000, to include this additional scope. EPA stated that they would accept this as meeting the intent of the milestone and would provide a comment that an EE/CA would still be required for public review. This path was followed by $B H I$ until the completion of the milestone deliverable. 


\section{ENVIRONMENTAL MANAGEMENT PERFORMANCE REPORT ENVIRONMENTAL RESTORATION \\ AUGUST 2000}

\section{PERFORMANCE OBJECTIVES: DQD}

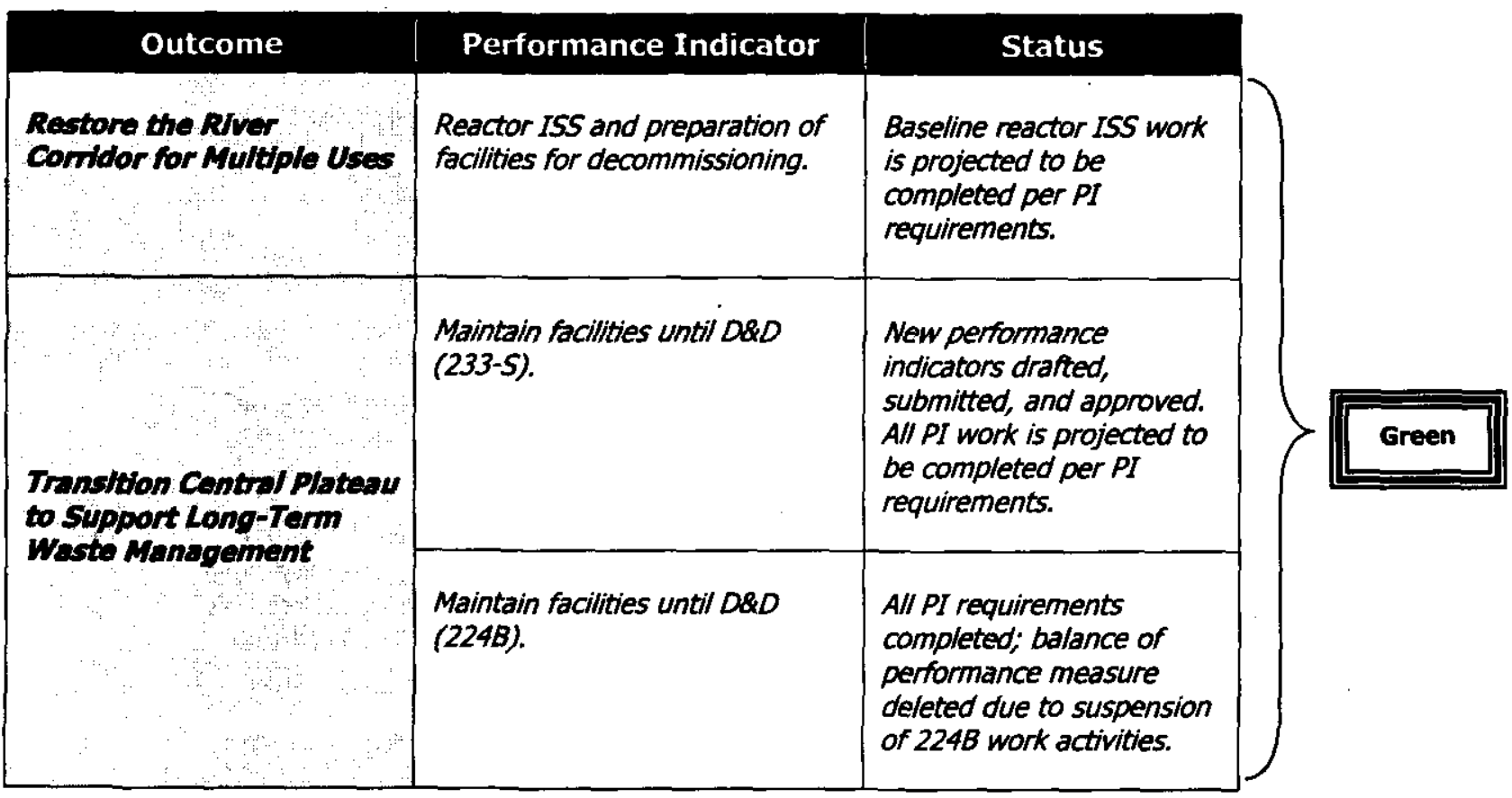

\section{PERFORMANCE MEASURES: DQD}

\begin{tabular}{|l|c|c|c|c|c|}
\hline & $\begin{array}{c}\text { DWP } \\
\text { FY00 }\end{array}$ & $\begin{array}{c}\text { FY00 Mgmt. } \\
\text { Commitments }\end{array}$ & $\begin{array}{c}\text { Current Baseline } \\
\text { (Incl. Baseline } \\
\text { Changes) }\end{array}$ & $\begin{array}{c}\text { Forecast } \\
\text { For } \\
\text { FYoo }\end{array}$ & $\begin{array}{c}\text { Completed } \\
\text { YTD }\end{array}$ \\
\hline Facilitios & 0 & 0 & $4^{b}$ & $4^{b}$ & $3^{c}$ \\
\hline
\end{tabular}

${ }^{1} 116-D, 116-D R, 119-D R$ and $108-F$

c 116-D, 116-DR, 119-DR (108-F Final Report scheduled for 9/00)

\section{STRETCH AND SUPERSTRETCH GOALSI ODD}

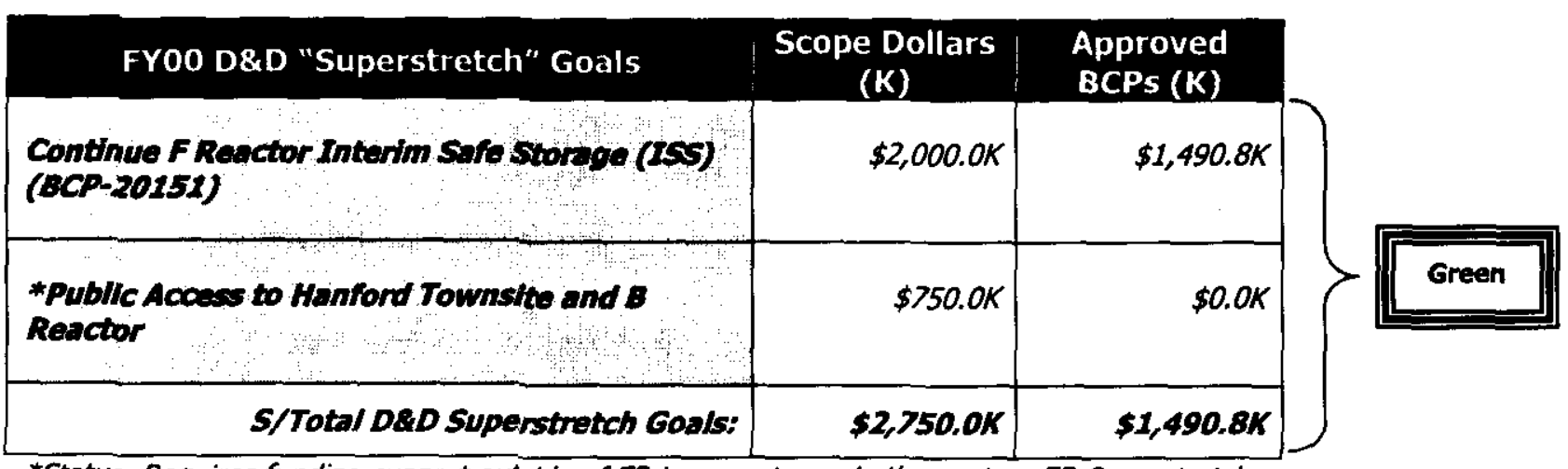

*Status: Requires funding support outside of ER to execute work, thus not an ER Superstretch. 
ENVIRONMENTAL MANAGEMENT PERFORMANCE REPORT

ENVIRONMENTAL RESTORATION

AUGUST $\mathbf{2 0 0 0}$

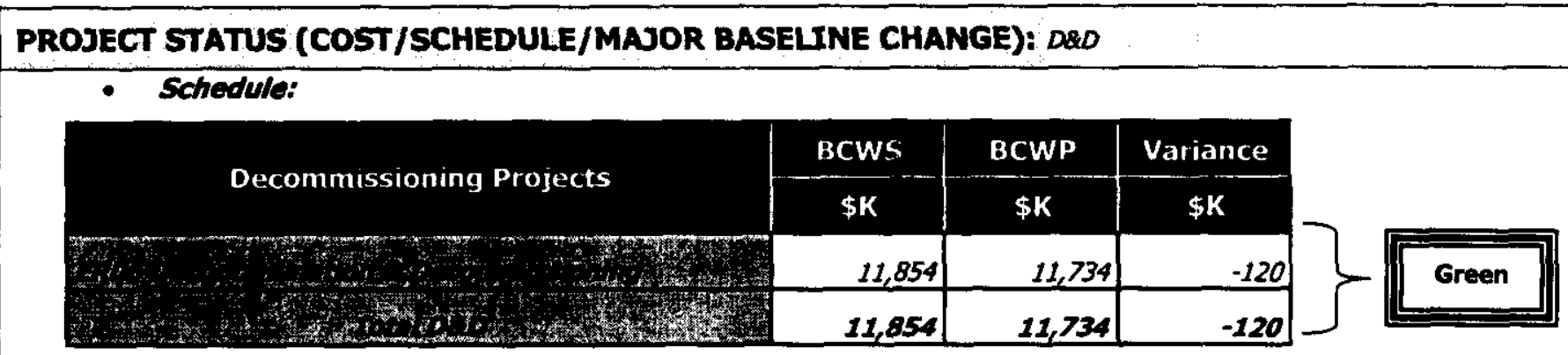

PAS-EROG - Decontamination and Decommiscioning

Schedule Variance $=-\$ 120 K ;-1.0 \%$ [Last Month: $\$ 471 K ; 4.4 \%$ ]

Cause: 233-S decommissioning: disposal of duct delayed pending fixing of internal contamination. Procurement of Standard waste box (SWB) waste containers is also behind schedule.

Resolution: Exhaust duct removal is planned to start in July after completing the Process Hood decontamination. Fixing of internal contamination is being coordinated with removal and disposal of roof exhaust duct, which is scheduled for completion in September. Waste containers are expected in July and shipment of TRU to Central Waste Complex (CWC) is scheduled for September.

Cause: Reactor ISS decommissioning: pipe and equipment removal outside reactor building delaved at $F$ due to Rigger support at higher priority locations (233-S and CDI Canyon)

Resolution: Work began in June but is intermittent due to Riggers also supporting SM\&T Canyon work and 233-S.

- Cost:

\begin{tabular}{|c|c|c|c|c|}
\hline \multirow{2}{*}{ Decommissioning Projects } & BCWP & ACWP & Variance & \\
\hline & $\$ \mathbf{K}$ & $\$ K$ & $\$ \mathbf{K}$ & \\
\hline 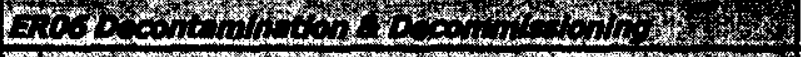 & 11,734 & 11,223 & 511 & Green \\
\hline 1.7. & 11,734 & 11,223 & 511 & \\
\hline
\end{tabular}

PBS-ERO6 - Decontamination and Decommiscioning

Cost Variance $=+\$ 511 K ;+4.4 \%$ [Last Month: $+\$ 504 K ;+4.9 \%$ ]

Cause: $F$ and DR ISS sample analysis cost is lower than expected due to utilizing larger data groups (economies of scale).

Resolution: Savings will be used to perform other remediation work.

Cause: 233-5 - Additional cost to correct airflow and installing electrical upgrades in the viewing room.

Resolution: Cost overruns are being trended. Engineering controls have been implemented to resume characterization activities. 


\title{
ENVIRONMENTAL MANAGEMENT PERFORMANCE REPORT ENVIRONMENTAL RESTORATION \\ AUGUST 2000
}

\begin{abstract}
REGULATORY ISSUES: $D$ DE
$D$ and $H$ Reactor Impacts of TPA Milestones: The acceleration of the reactor ISS projects is no longer consistent with the current M-93 milestones, especially the competitive procurement and renegotiating milestone (M-93-12) for DR.

Status: Initial discussions with the regulators have started which should lead to resolution in the near future.

$D$ and $H$ Reactor Engineering Evaluation/Cost Analysis (EE/CA): The D and H Reactor EE/CA schedule required regulator review to be completed by April 19, to meet the established Detailed Work Plan (DWP) goals and deadlines. EPA has also proposed TPA Reactor milestones before approving an Action Memo for D\&H. EPA has also proposed sending the EE/CA to the EPA National Remedy Review Board located in Washington D.C.

Status: $B C P$ approved to split D\&H EE/CA into the two documents. Transmitted for DOE/Regulator Review on June 13. Discussions opened with regulators on TPA Reactor Milestones. Developing new schedule for regulators showing when their involvement is required for the remainder of the fiscal year.

Demolition Equipment: Demolition equipment (track hoe excavators and shuttle truck) breakdowns continue to cause delays to demolition activities.

Status: Mechanics continue to repair the equipment as quickly as possible. Impact sheets are being completed to track the delays. Problems/impacts were presented to RMT. Field Support prepared an equipment priority list and was directed to prepare a procurement plan for a new excavator, which was completed. Procurement options are currently being evaluated. Plans are to purchase equipment if supplemental funding in FY 2001.
\end{abstract}

EXTERNAL ISSUES (1.e. HAB, Congress, etc.): DBD None identified at this time.

DOE-RL \& HQ ISSUES/REQUESTS (not covered elsewhere): $D Q D$ None identified at this time.

INTEGRATION ACTIVTIES: DBD

None identified at this time. 


\title{
ENVIRONMENTAL MANAGEMENT PERFORMANCE REPORT ENVIRONMENTAL RESTORATION

\author{
AUGUST 2000
}

\section{SECTION B - RESTORING THE RIVER CORRIDOR}

\author{
Financial / Performance Measures data as of month-end June. \\ All other data as of July 27, 2000 (unless otherwise noted). \\ Program Management \& Support (PM\&S)
}

\begin{abstract}
NoOOMPLISHMENTS: PMES
COMPITANCE, QUALTY, SAFEM, AND HEALTHF

Compliance and Quallty Programs: A RCRA inspection was conducted in the 100 Area as required by the Hanford site-wide RCRA permit. No reportable items were noted. Several housekeeping issues were identified, however. These housekeeping items were documented and will be tracked to ensure corrective actions are completed.
\end{abstract}

A surveillance was performed at the 271- $U$ and 1330-N <90-Day Hazardous Waste Storage Pads, plus two satellite accumulation areas (SAAs) at the REDOX facility. The surveillance inspections were performed to review waste management practices for compliance with regulatory and procedural requirements. The surveillance focused on container management practices, emergency action plans, spill kit inventory, inspection and waste container records. Overall, the surveillance resulted in ten observations. A written response was prepared to address the issues identified.

The required annual update of the ERC Quality Program Manual was submitted to RL for review and approval.

Safety and Health: Two self-assessments were completed in June with no actions identified. The self-assessments included the annual Respiratory Protection Program and the Hazardous Waste Worker Program implementation.

Development progressed on new and revised procedures that is required to ensure ERC is in full compliance with the revised 10 CFR 835 regulation by July 31. The effort is on schedule.

\section{PROGRAMAND PROJFCT SUPPORT:}

Procurement and Property Management: BHI participated in a peer review at Argonne National Lab (ANL) in support of the DOE Procurement Evaluation and Reengineering Team (PERT). This procurement peer review process assists DOE in improving consistency between various sites, and supports DOE's objective to continue moving away from prescriptive transactional file review processes. The peer review was also an excellent forum to share procurement best practices and experiences in a very constructive and in-depth manner.

Extermal Affairs: A recognition event was held to acknowledge B Reactor Museum Association (BRMA) members for their voluntary assistance in conducting reactor tours and their persistence in promoting the museum concept. Approximately 80 invited guests attended including six media representatives. RL and BHI management pledged support to preserving the museum and developing the next steps in concert with the regulators and stakeholders.

Document and Information Services (DIS): DIS representatives made a presentation on BHI's protocols for electronic information transfer to the DOE Office of Scientific and Technical Information (OSTI) at the June 15 meeting of the Hanford Technical Information Council (HTIC). In response to questions from the RL Director of Intergovernmental Public and Institutional Affairs, it was noted that BHI is the only contractor in the DOE complex to send $100 \%$ of its information to OSTI in electronic formats. 


\section{ENVIRONMENTAL MANAGEMENT PERFORMANCE REPORT ENVIRONMENTAL RESTORATION \\ AUGUST 2000}

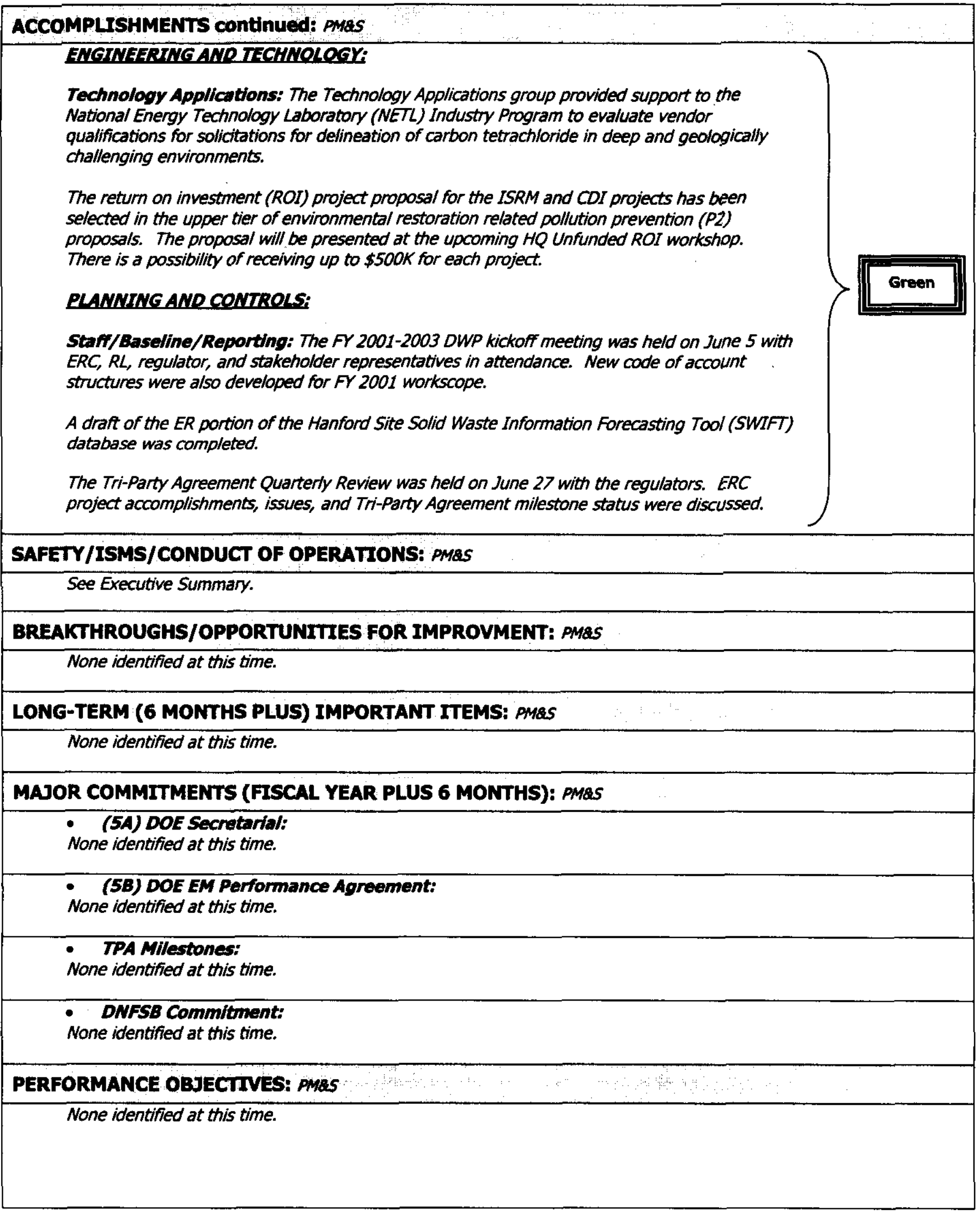




\section{ENVIRONMENTAL MANAGEMENT PERFORMANCE REPORT ENVIRONMENTAL RESTORATION \\ AUGUST 2000}

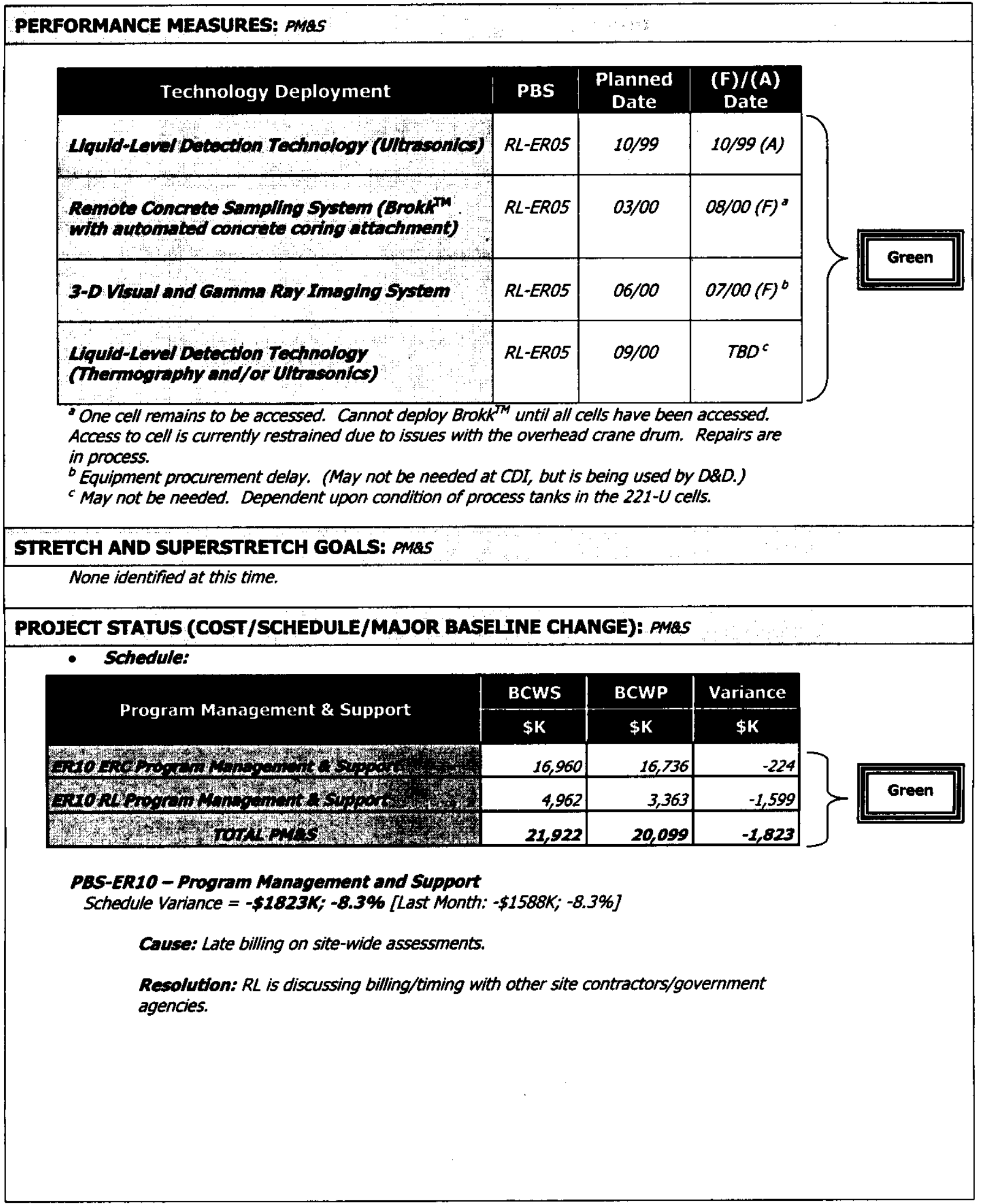




\section{ENVIRONMENTAL MANAGEMENT PERFORMANCE REPORT ENVIRONMENTAL RESTORATION \\ AUGUST 2000}

\section{PROJECT STATUS (COST/SCHEDULE/MAJOR BASELINE CHANGE) continUEd: PM\&S}

- Cost:

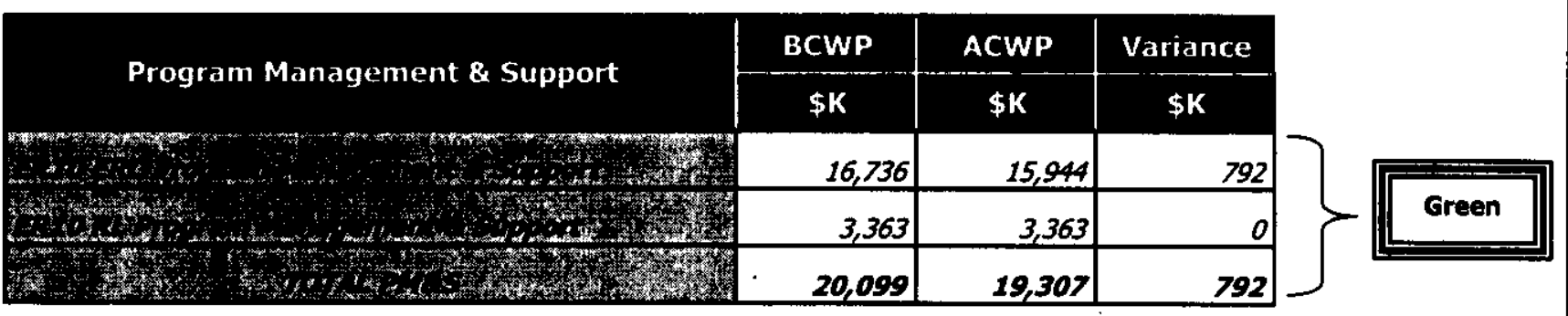

PBS-ER1O - Program Management and Support

Cost Variance $=+\$ 792 K ;+3.9 \%$ [Last Month: $+\$ 494 K ;+2.8 \%$ ]

Cause: Fewer special requests and audits have resulted in savings; procurement staff efficiencies, Y2K underruns, reduced revegetation support, baseline management efficiencies, and credit received as result of the 96 final incurred actual rebill cost.

Resolution: None required.

\section{REGULATORY ISSUES: PMAS}

None identified at this time.

EXTERNAL ISSUES (l.e. HAB, Congress, etc.); PM\&S

None identified at this time.

DOE-RL \& HQ ISSUES/REQUESTS (not covered elsewhere): PM\&S

None identified at this time.

\section{INTEGRATION ACTIVITIES: PMOS}

None identified at this time. 


\section{Richland Operations Office Environmental Restoration \\ Environmental Management Performance Report}

\section{Section C - Central Plateau Infolintition}

August 2000

- Groundwater / Vadose Zone Integration Project

- Surveillance / Maintenance \& Transition Projects

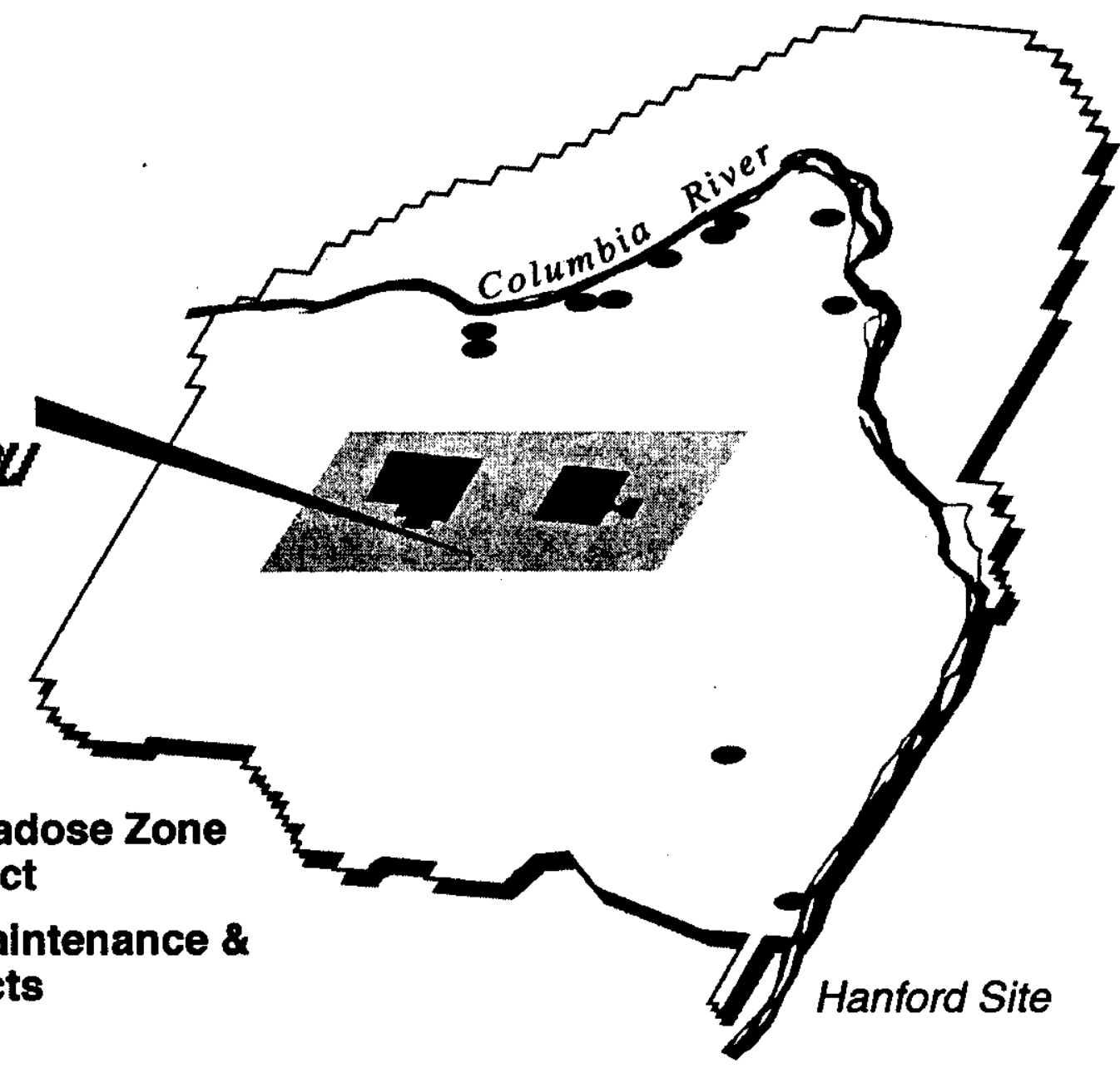

Focused on Progress...

Focused on Outcomes!

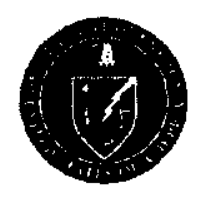

Department of Energy Richland Operations Office

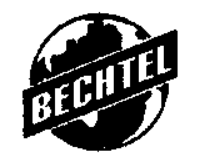

Bechtel Hanford, Inc.

Environmental Restoration Contractor 
ENVIRONMENTAL MANAGEMENT PERFORMANCE REPORT ENVIRONMENTAL RESTORATION

AUGUST 2000

\section{Groundwater/Vadose Zone Integration (GW/VZ)}




\title{
ENVIRONMENTAL MANAGEMENT PERFORMANCE REPORT ENVIRONMENTAL RESTORATION \\ AUGUST 2000
}

\section{SECTION C - TRANSITIONING THE CENTRAL PLATEAU}

\author{
Financial / Performance Measures data as of month-end June. \\ All other data as of July 27, 2000 (unless otherwise noted). \\ Groundwater/Vadose Zone Integration (GW/VZ):
}

ACCOMPLISHMENTS, GWWZ GWIVITIEGRATTON PROJECTE

General Project Activities: The second meeting with the National Academy of Sciences was conducted at Hanford to review the Science \& Technology (S\&T) component of the Integration Project.

Public Involvement: The project participated in the Oregon Hanford Waste Baard meetings conducted during June and assisted U.S. Department of Energy (DOE), Headquarters (HQ) in the transmittal and distribution of the Semi-Annual Groundwater/Vadose Zone Report to members of the Northwest Congressional Delegation.

Sclence and Technology: Final fivid injections were completed for the vadose zone transport experiment. The main objectives of the vadose zone transport field study are to focus on the underground tank leak issues, improve vadose monitoring capabilities, identify key transport processes, and provide data for model verification.

System Assessment Capabllity; A management review of the System Assessment Capability. (SAC), Revision 0, "Assessment Description, Requirements, Software Design and Test Plan" was performed. The review team included members of the Integration Project Expert Panel (IPEP) and Sandia National Laboratory.

\section{GROUNDWATER MANAGEMENT:}

In Situ REDOX Manipulation Project: The construction contract for the ISRM evaporation pond was awarded, and field work commenced in June. The first chemical injection is planned for late July.

Well Drilling, Maintenance, and Decommiscioning: Well maintenance activities continued in June. Maintenance on 134 out of 138 planned wells has been completed through June. The well drilling subcontract was issued for bid. Contractor mobilization is expected in late July.

Long-Term Groundwater Monitoring: A workshop was conducted with RL, Ecology, and contractors to focus on the long-term path forward for Liquid Effluent Retention Facility (LERF) monitoring activities. Borehole data reports were completed for wells constructed at the S-10 pond and ditch (Well 299-W26-13), single shell tanks (SST) TX-TY (299-W15-41), and SSTs $B-B X-B Y$ (299-E33-334 and 299-E33-335).

Tritum Inveatlgation: The draft waste management plan that addresses the tritium investigation of the 618-11 burial ground was approved by the regulators in mid July. A waste pad is also being prepared in the 300 Area for investigation waste.

Summary of Five Pump and Treat Systems; All groundwater pump and treat systems operated above planned $90 \%$ availability levels through June. Since system inception, the five pump and treat systems have processed over 4.0 billion liters of groundwater, removing 4,269 kilograms of carbon tetrachloride, 177 kilograms of chromium, and 0.840 curies of strontium. Approximately 762.2 million liters of groundwater have been processed in FY 2000, removing approximately 865.2 kilograms of carbon tetrachloride, 44.5 kilograms of chromium, and 0.134 curies of strontium. 


\section{ENVIRONMENTAL MANAGEMENT PERFORMANCE REPORT ENVIRONMENTAL RESTORATION \\ AUGUST 2000}

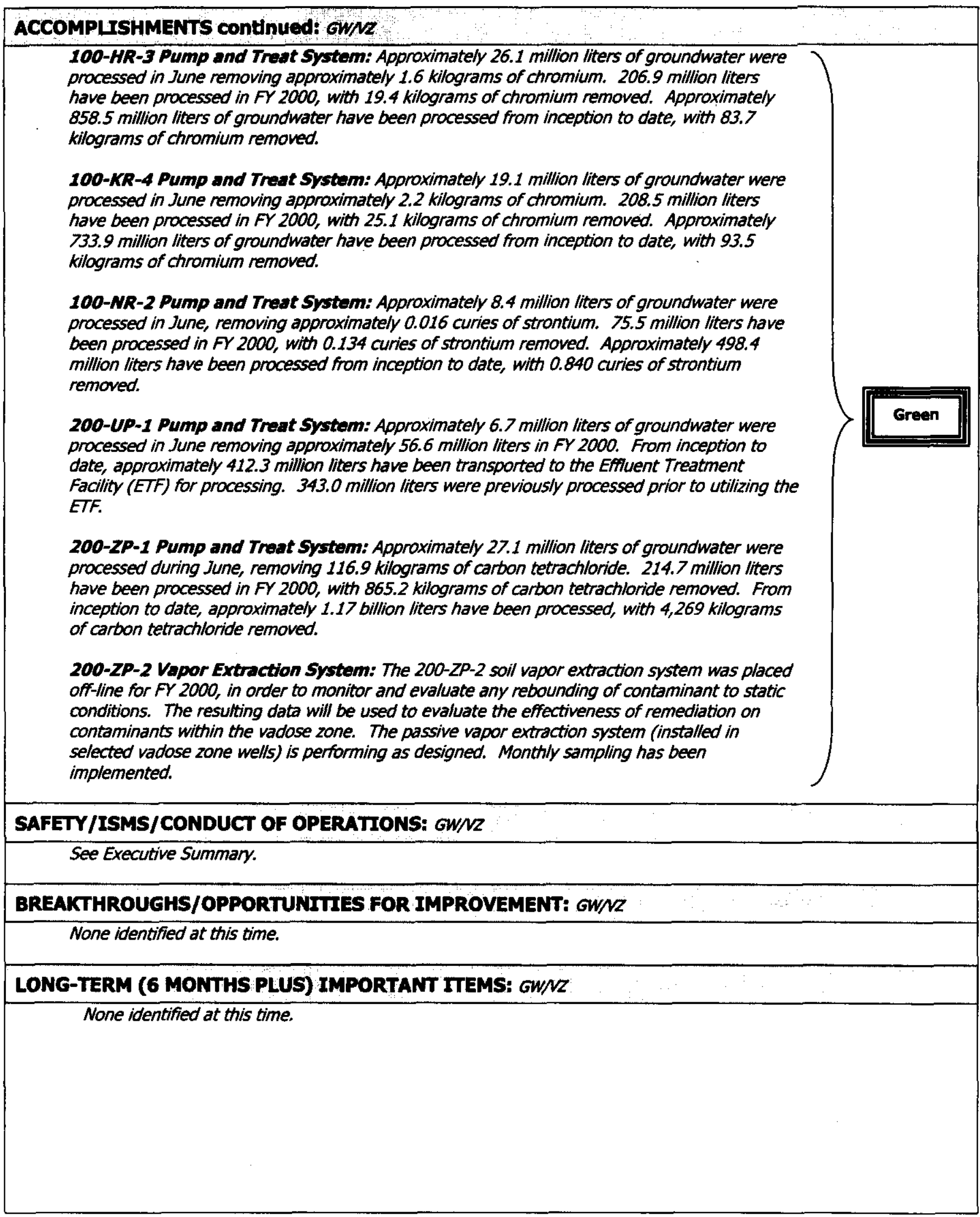




\section{ENVIRONMENTAL MANAGEMENT PERFORMANCE REPORT ENVIRONMENTAL RESTORATION \\ AUGUST 2000}

\section{MAJOR COMMITMENTS (FISCAL YEAR PLUS 6 MONTHS): GWNZ}

- DOE Secretarial:

Transmit Update of the Vadose Zone Science and Technology Roadmap (PBS VZ01) due April 30.

Status: Complete. Draft was transmitted to RL on April 28.

Install Wells and Initiate Injection of the Barrier for Phase I of the In Situ REDOX Groundwater Remediation (PBS EROB) due September 30.

Status: Forecasted for completion by September 30. (16-well installations were completed on April 24).

- Ecology concurrence with the activities described in the Revision 1, Remedial Design Report / Remedial Action Work Plan (DOE/RL-99-51, Rev. 1, June 2000).

- The evaporation pond contract was awarded in early June. The contractor mobilized mid-June to construct the evaporation pond used for well extraction waste management activities.

- Well injections are scheduled to begin August 1, to be completed by the end of September.

Complete the Semi-Annual Groundwater/Vadose Zone Report (December 1999 - March 2000) (PBS VZO1) due May 31.

Status: Complete. Final document was transmitted to RL on May 31 .

- DOE EM Performance Agreement:

None identified at this time. 


\section{ENVIRONMENTAL MANAGEMENT PERFORMANCE REPORT ENVIRONMENTAL RESTORATION \\ AUGUST 2000}

\begin{tabular}{|c|c|c|c|c|}
\hline \multicolumn{4}{|c|}{$\begin{array}{r}\text { MAJOR COMMITMEN } \\
\text { TPA MIlestones: }\end{array}$} & \\
\hline Milestone & Description & $\begin{array}{l}\text { Due } \\
\text { Date }\end{array}$ & $\begin{array}{l}(\mathbf{F}) /(\mathbf{A}) \\
\text { Date }\end{array}$ & \\
\hline$M-13-22$ & $\begin{array}{l}\text { Submit U-Pond/Z-Ditches Cooling Water Group } \\
\text { Work Plan }\end{array}$ & $12 / 31 / 99$ & $12 / 14 / 99$ (A) & \\
\hline$M-24-00 K$ & $\begin{array}{l}\text { Install RCRA Groundwater Monitoring Wells at the } \\
\text { Rate of up to } 50 \text { in Calendar Year } 1999 \text { if } \\
\text { Required }\end{array}$ & $2 / 29 / 00$ & $2 / 17 / 00(A)$ & \\
\hline$M-2441$ & $\begin{array}{l}\text { Install Three (3) Additional RCRA Wells for the } \\
\text { SST WMA S-SX }\end{array}$ & $2 / 29 / 00$ & $2 / 17 / 00(A)$ & \\
\hline$M-24-42$ & $\begin{array}{l}\text { Install One (1) Replacement Well for the } \\
216-5-10 \text { Pond }\end{array}$ & $2 / 29 / 00$ & $2 / 17 / 00(A)$ & \\
\hline$M-24-4$ & $\begin{array}{l}\text { Install One (1) Additional RCRA Well for the SST } \\
\text { WMA } T X-T Y\end{array}$ & $2 / 29 / 00$ & $2 / 17 / 00(A)$ & \\
\hline $\begin{array}{c}M-24-4 \\
\end{array}$ & $\begin{array}{l}\text { Install One (1) Replacement Well for the } 216-B-3 \\
\text { Pond (This is an extension of a CERCLA vadose } \\
\text { borehole.) }\end{array}$ & $2 / 29 / 00$ & $2 / 17 / 00(A)$ & \\
\hline$M-24-45$ & $\begin{array}{l}\text { Install Two (2) Additional RCRA Wells for the SST } \\
\text { WMA B-BX-BY }\end{array}$ & $2 / 29 / 00$ & $2 / 17 / 00(A)$ & \\
\hline$M-13-23$ & Submit 200-TW-1 Work Plan & $8 / 31 / 00$ & $8 / 31 / 00(F)$ & Green \\
\hline$M-13-24$ & Submit 200-TW-2 Work Plan & $8 / 31 / 00$ & $8 / 31 / 00(F)$ & \\
\hline$M-13-00 K$ & $\begin{array}{l}\text { Submit One (1) } 200 \text { NPL RI/FS (RFI/CMS) Work } \\
\text { Plan }\end{array}$ & $12 / 31 / 00$ & $12 / 31 / 00(F)$ & \\
\hline$M-13-25$ & $\begin{array}{l}\text { Submit Uranium Rich Process Waste Group } \\
(200-P W-2) \text { Work Plan }\end{array}$ & $12 / 31 / 00$ & $12 / 31 / 00(F)$ & \\
\hline$M-24-46$ & Install two (2) additional wells at SST WMA S-SX & $12 / 31 / 00$ & $12 / 31 / 00(F)$ & \\
\hline$M-24-47$ & Install four (4) additional wells at SST WMA T & $12 / 31 / 00$ & $12 / 31 / 00(F)$ & \\
\hline$M-24-48$ & $\begin{array}{l}\text { Install four (4) additional wells at SST WMA } \\
T X-T Y\end{array}$ & $12 / 31 / 00$ & $12 / 31 / 00(F)$ & \\
\hline$M-24-0 O L$ & $\begin{array}{l}\text { Install RCRA Groundwater Monitoring Wells at the } \\
\text { Rate of up to } 50 \text { in Calendar Year } 2000 \text { if } \\
\text { Required }\end{array}$ & $12 / 31 / 00$ & $12 / 31 / 00(F)$ & \\
\hline $\begin{array}{l}\text { DNFSB } \\
\text { None identifit }\end{array}$ & $\begin{array}{l}\text { imitment: } \\
\text { t this time: }\end{array}$ & & & \\
\hline
\end{tabular}




\section{ENVIRONMENTAL MANAGEMENT PERFORMANCE REPORT ENVIRONMENTAL RESTORATION AUGUST $\mathbf{2 0 0 0}$}

PERFORMANCE OBJECTIVES: GW/R

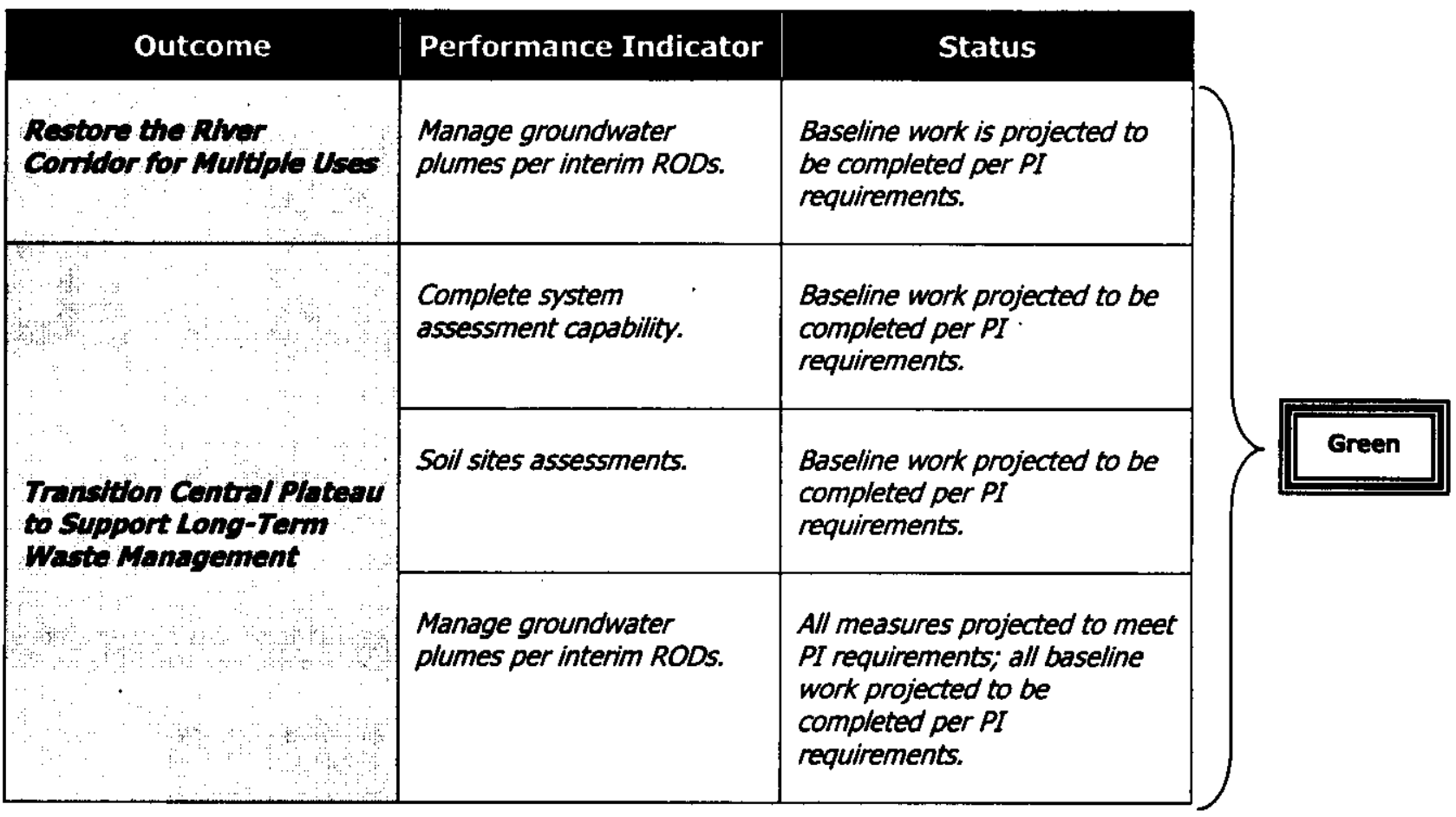

\section{PERFORMANCE MEASURES: GWNZ}

None planned in FY 2000.

\section{STRETCH AND SUPERSTRETCH GOALS: GWNZ}

\begin{tabular}{|c|r|r|}
\hline FY00 GW/VZ "Stretch" Goals & \multicolumn{1}{c|}{$\begin{array}{c}\text { Scope } \\
\text { Dollars (K) }\end{array}$} & $\begin{array}{c}\text { Approved } \\
\text { BCPs (K) }\end{array}$ \\
\hline $\begin{array}{l}\text { *Complete Partitioning of Intenwe/l Treatment at } \\
\text { 200-ZP-1 and 200-ZP-2 }\end{array}$ & $\$ 706.0 \mathrm{~K}$ & $\$ 414.0 \mathrm{~K}$ \\
\hline S/Total GW - Vadose Zone Stretch Gaals: & $\$ 706.0 \mathrm{~K}$ & $\$ 414.0 \mathrm{~K}$ \\
\hline Green
\end{tabular}

*Status: Efficiencies identified. BCP 20246 was approved on July 25 to deepen elected vadose well in the 200-PW-1 in preparation of the PIT test. 


\section{ENVIRONMENTAL MANAGEMENT PERFORMANCE REPORT ENVIRONMENTAL RESTORATION \\ AUGUST 2000}

\section{STRETCH AND SUPERSTRETCH GOALS continued: GW/VZ}

\begin{tabular}{|c|c|c|c|}
\hline FYoo GW/VZ "Superstretch" Goals & $\begin{array}{c}\text { Scope } \\
\text { Dollars (K) }\end{array}$ & $\begin{array}{l}\text { Approved } \\
\text { BCPs (K) }\end{array}$ & \\
\hline $\begin{array}{l}\text { Provide Parmanent Solution for Hanford Groundwater } \\
\text { plumes }\end{array}$ & $\$ 750.0 K$ & $\$ 0.0 \mathrm{~K}$ & \\
\hline Complote Remediation of $C O \mathrm{Sq}$. ML of Hanford Sites & & & Green \\
\hline (1) * Venth and admintstratively clase 170 wells & $\$ 450.0 K$ & $\$ 104.0 K$ & \\
\hline (2) *Decommkstoning of 200 wells & $\$ 900.0 K$ & $\$ 1478.0 K$ & \\
\hline S/Total GW - Vadose Zone Superstretch Goals: & $\$ 2,100.0 K$ & $\$ 1582.0 K$ & \\
\hline
\end{tabular}

\section{PROJECT STATUS (COST/SCHEDULE/MAJOR BASELINE CHANGE: GWNZ}

\section{- schedule:}

\begin{tabular}{|c|c|c|c|c|}
\hline \multirow{2}{*}{ Groundwater Vadose Zone Integration } & BCWS & $\mathbf{B C W P}$ & Variance & \multirow{5}{*}{ Green } \\
\hline & $\$ \mathbf{K}$ & $\$ \mathbf{K}$ & $\$ \mathbf{K}$ & \\
\hline 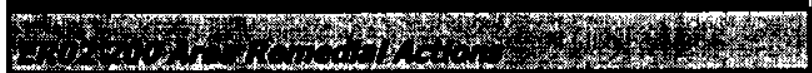 & 3,353 & 3,235 & -118 & \\
\hline 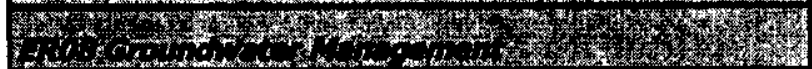 & 17,978 & 16,518 & $-1,460$ & \\
\hline S & 8,091 & 7,641 & -450 & \\
\hline 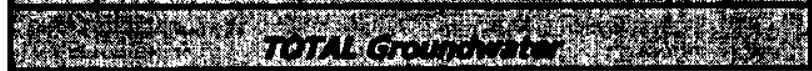 & 29,422 & 27,394 & $-2,028$ & \\
\hline
\end{tabular}

PBS-ERO2 - 200 Area Remedlal Action (Assessment)

Schedule Variance $=-\$ 118 K ;-3.5 \%$ [Last Month: $-\$ 141 K ;-4.3 \%$ ]

Cause: Miscellaneous assessment work rescheduled, pending RL decision on 200 Area Assessment Strategy.

Resolution: None required.

\section{PBS-EROS - Groundwater Management}

Schedule Variance $=-\$ 1460 K ;-8.1 \%$ [Last Month: $-\$ 1565 K ;-9.7 \%$ ]

Cause: ISRM injection and withdrawal materials were loaded to arrived earlier than actual procurement.

Resolution: None required; material delivery will support ISRM injection work.

Cause: Groundwater Monitoring sampling collection and analysis (PNNL) fell behind schedule in October/November, due to difficulties in bargaining unit personnel, and has not yet recovered.

Resolution: Additional NCOs have been added and a recovery schedule implemented; unexpected sampling at the 618-11 Burial Ground will impact recovery timing; full recovery is not expected; carryover forecast. 


\section{ENVIRONMENTAL MANAGEMENT PERFORMANCE REPORT ENVIRONMENTAL RESTORATION \\ AUGUST 2000}

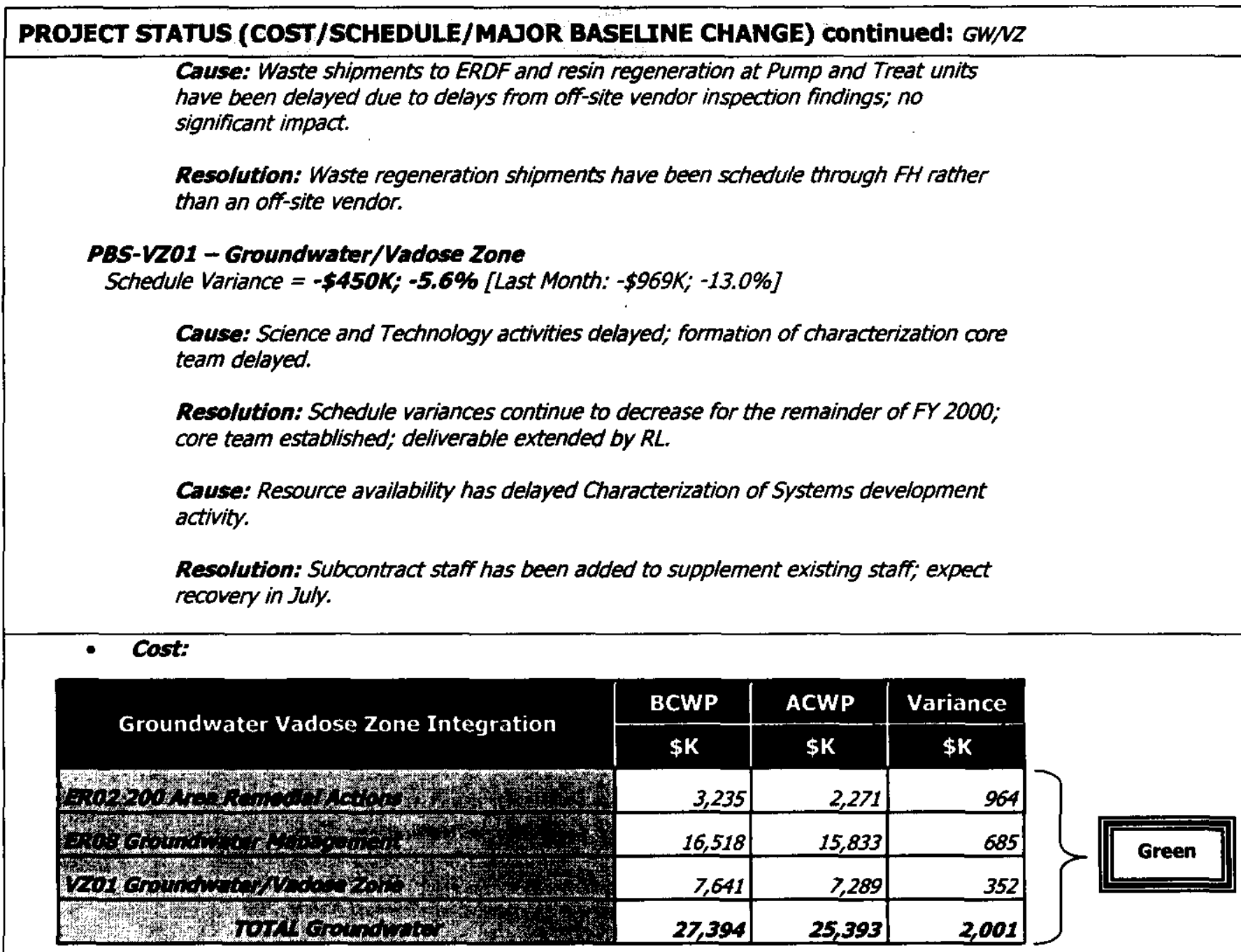

PBS-ERO2 - 200 Area Remedial Action(Assessment)

Cost Variance $=+\$ 964 K ;+29.8 \%$ [Last Month: $+\$ 987 K ;+31.8 \%$ ]

Cause: Efficiencies learned in prior work were applied to Gable Mountain and B-Pond test pit trenching, resulting in savings. Borehole drilling was combined with RCRA drilling resulting in cost savings.

Resolution: Savings will be used to perform other remediation work.

PBS-EROB - Groundwater Management

Cost Variance $=+\$ 685 K ;+4.1 \%$ [Last Month: $+\$ 559 K ;+3.8 \%$ ]

Cause: Underrun due to completion of drilling of ISRM ahead of schedule. Underruns in routine well maintenance as some activities were cancelled due to unresolved waste issues.

Resolution: Savings will be used to perform other remediation work.

PBS-VZO1 - Groundwater/Vadose Zone

Cost Variance $=+\$ 352 K ;+4.6 \%$ [Last Month: $+\$ 412 K ;+6.3 \%$ ] 
PROJECT STATUS (COST/SCHEDULE/MAJOR BASELINE CHANGE) continued: GWNZ

Cause: Efficiencies in Science and Technology labor and characterization of systems performed with fewer resources.

Resolution: Savings will be used to perform other remediation work.

REGULATORY ISSUES: GWNZ

Monitoring Wells: Tritium investigation is being conducted near the 618-11 Burial Ground.

Status: Draft A of the DQO Report for Phase II efforts has been reviewed by the regulators and comments are pending. Sampling and analysis plans (SAPS) for resampling key groundwater wells near the 618-11 burial ground and for investigating the nature and extent of the 618-11 groundwater plume have been reviewed by the regulators. These SAPS are scheduled to be approved in July and implemented during the July/August timeframe. A waste management plan (WMP) for this project has been prepared and approved by the regulators.

200-2P-2: Regulatory agencies desire continued operation of the 200-ZP-2 vapor extraction unit (not included in DWP).

Status: Project personnel met with EPA (Doug Sherwood), to discuss the need to restart ZP-2 pending completion of the cost estimate to perform the Partitioning Interwell Tracer Test (PITT) test in lieu of restarting ZP-2 this fiscal year. Decision has been made to proceed with the PITT test. PITT test estimate is forwarded to be completed by the end of July, with management review to be completed by mid August. BCP 20246 was approved on July 26 to implement scope associated with Deepen the Elected Vadose Well in 200-PW-1 in preparation of the PITT test.

200 Area RI/FS: Approximately 800 soil contaminated sites (200 Area) grouped into 23 process-based operable units are to be characterized by 2008 and remediated by 2018. Currently, an out-year funding allowance of $\$ 2 M$ has been added to the GWNZ Project for 200 Area characterization work, but short of the \$6-8M target required to meet TPA milestones. Long-term, RL must decide a budgetary position toward assessment and cleanup of the 200 Area liquid waste sites. The regulator position is to submit TPA change packages for each operable unit work plan for enforceability in completing the RI through ROD based on existing TPA milestones.

Status: DOE has prepared a draft TPA change package for the 200-CW-1 operable unit containing RI/FS milestones for FY 2000 only. DOE is addressing the need for TPA change package proposals for other work plans that require a proposed TPA change package in order to gain necessary regulatory approval of the work plan. In addition, DOE is currently seeking to justify and identify additional funds for characterization. The ERC team in conjunction with RL management has developed a strategy to propose to the regulators to discuss this approach to initiating the work.

200 PW-2 Work Plan: RL direction is needed on proceeding with the 200-PW-2 Work Plan. Initiating work on the 200-PW-2 OU is not consistent with funding levels nor RL's path forward strategy for the 200 Area.

Status: TPA Milestone M-13-25 requires that the Draft A 200-PW-2 work plan be submitted to the regulators by December 31. RL has directed BHI to resume development of the work plan and work is underway. 


\section{ENVIRONMENTAL MANAGEMENT PERFORMANCE REPORT ENVIRONMENTAL RESTORATION \\ AUGUST 2000}

\section{REGULATORY ISSUES continued, GWNZ}

M-24-00L - CYOO RCRA Compliance Well Installation: The number and location of wells

have been determined. However, the interim milestones are in dispute.

Status: TPA change request was approved on June 26. Three interim milestones were established that identify a total of ten wells to be installed by 12/31/00. Two additional interim milestones were established that identify five wells to be installed by 4/30/01 (under M-24-00M). Due to lack of sufficient funding, BHI is using $\$ 1 \mathrm{M}$ of FY 2000 funds to support RCRA well installation.

\section{WASTE MANAGEMENT ISSUES:}

- Blosite Notice of Correction: Notice of Correction was received from Ecology on May 26. $D O E / B H I$ response was issued on June 26.

Status: Requirements include (1) Issue formal notification to Rabanco and City of Richland Landfills (completed), and (2) Designate and ship BioSite waste (135 drums), due end of September.

- Purgewater Secondary Waste Management: Discrepancy in the interpretation of the Purgewater Strategy applicability. Direction given by DOE is to get compliant with all LDR requirements.

Status: Interim phase was initiated and a screening was completed for the potential listed waste codes to be applied. Activities on site will be conducted as planned, with a conservative application of the listed waste codes to the secondary wastes. A longterm resolution has also been accepted by DOE, to conduct a Listed Waste Applicability Assessment to minimize the listed waste codes to be applied on this waste stream. Talks with the regulators have been informal, awaiting the resolution of the Multi Media Investigation (MMI) case.

- 200-CW-1 IDW Waste Disposal at ERDF: A request for a contained-in determination was approved for the 200-CW-1 IDW waste by Ecology. Waste had to be removed from site by July 14, as per Ecology approved extension. Waste was shipped to ERDF, with approval from EPA. EPA is not allowing the final disposal of this waste since there is not a CERCLA-type document that covers this waste. The waste was shipped to ERDF as per an approved Waste Control Plan, which is not recognized by EPA as a CERCLA document.

Status: Waste is staged at ERDF. DOE project management is working to resolve this issue with EPA and Ecology.

- K Basins Well Maintenance Purgewater: Purgewater from a well maintenance activity was discharged to the ground (130 gal and $10 \mathrm{gal})$. An Unusual Occurrence was filed by $\mathrm{FH}$ and the regulators notified of potential breach of the 216 Permit and the Purgewater strategy. The initial regulatory analysis does not support breach of the 216 Permit requirements, since purgewater management is excluded from the 216 provisions. It is very likely that the Purgewater Strategy restrictions on the areas of discharge of purgewater have been violated.

Status: Further analysis of the implementation of Purgewater is ongoing. The language in the Purgewater Strategy will be reviewed and renegotiated with the regulators to remove conflicting and vague language that resulted in such an occurrence.

EXTERNAL ISSUES (i.e. HAB, Congress, etc.): GW/Z

None identified at this time. 
DOE-RL \& HQ ISSUES/REQUESTS (not covered elsewhere): GW/NZ None identified at this time.

INTEGRATION ACTIVITIES: GWNZ

None identified at this time. 


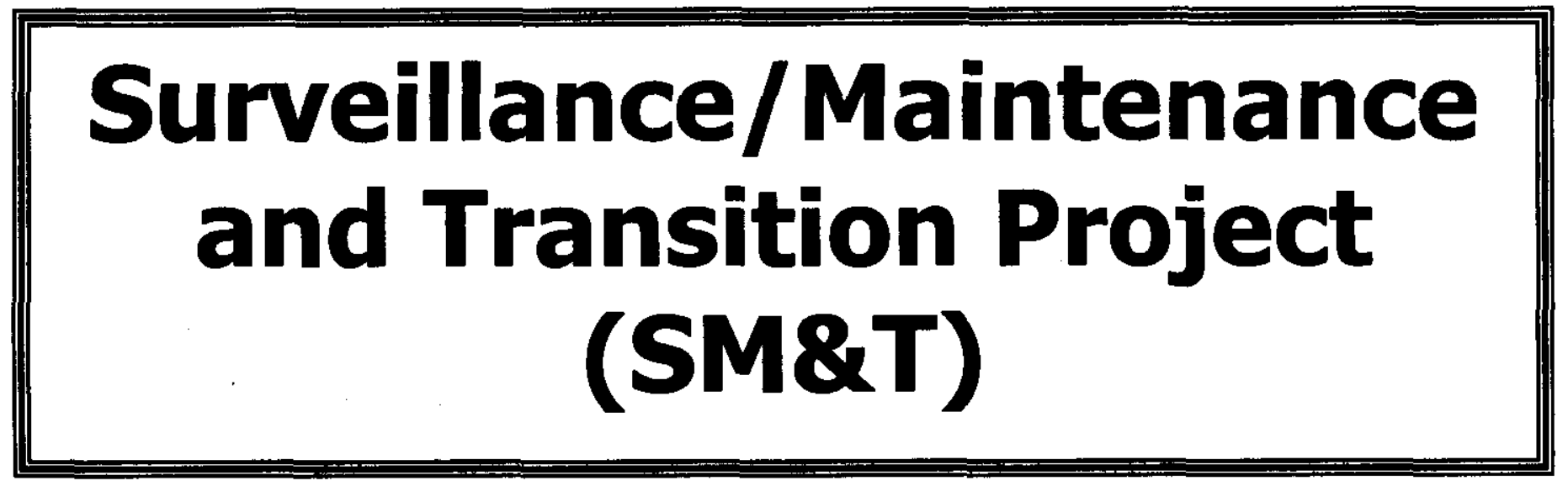




\section{ENVIRONMENTAL MANAGEMENT PERFORMANCE REPORT ENVIRONMENTAL RESTORATION AUGUST 2000}

\section{SECTION C - TRANSITIONING THE CENTRAL PLATEAU \\ Financial / Performance Measures data as of month-end June. All other data as of July 27, 2000 (unless otherwise noted). \\ Surveillance/Maintenance \& Transition Project (SM\&T): \\ ACCOMPLTSHMENTSF SHat}

Survelllance and Maintenance: S\&M activities that were performed in June to ensure inactive facility integrity and safety included the following:

- Completion of the readiness review for the REDOX Facility plutonium loadout hood work. Sample hood work and encapsulation were completed.

- Completion of all field work and final report associated with the REDOX miscellaneous contaminated area stabilization.

- Completion of the construction and startup of the $100 \mathrm{~N}$ Area water plant, and completion of Phase I deactivation of the old water plant.

- Completion of the KE/KW acid tank sample work activities. Tanks were sampled and found that they can be treated as noncontaminated waste.

- Completion of sealing all planned 84 passive vents source elimination at the RARA sites approximately three weeks ahead of schedule. The final report is in progress.

Canyon Disposition Initiative: Six cells were accessed during June in support of COI at the $U$ Plant (221-U Building) canyon facility. Only one cell remains to be opened and is scheduled for access. In order to open the remaining cell, two heavy lifts (greater than 45 metric tons [50 tons]) will be required to remove old $100 \mathrm{~N}$ Reactor fuel casks. A total of $38 \mathrm{cells}$ will have been accessed upon project completion. The railroad tunnel door was opened and surveyed. Concrete floor samples were then taken for characterization.

Preparation continued for remote coring sampling of the CDI cells utilizing the Brokk ${ }^{\text {TM }}$ coring concrete machine. A list of cells is being finalized that will be remotely sampled.

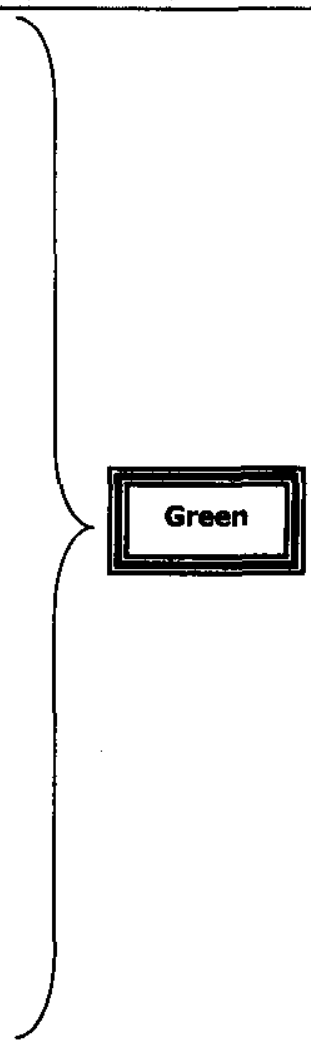

\section{SAFETY/ISMS/CONDUCT OF OPERATIONS: SMET}

See Executive Summary.

BREAKTHROUGHS/OPPORTUNTTES FOR IMPROVEMENT: SMAT

None identified at this time.

LONG-TERM (6 MONTHS PLUS) IMPORTANT ITEMS: SM\&T

None identified at this time.

MAJOR COMMITMENTS (FISCAL YEAR PLUS 6 MONTHS): SMRT

- DOE Secretarial:

None identified at this time.

- DOE EM Performance Agreement:

None identified at this time. 


\section{ENVIRONMENTAL MANAGEMENT PERFORMANCE REPORT ENVIRONMENTAL RESTORATION \\ AUGUST 2000}

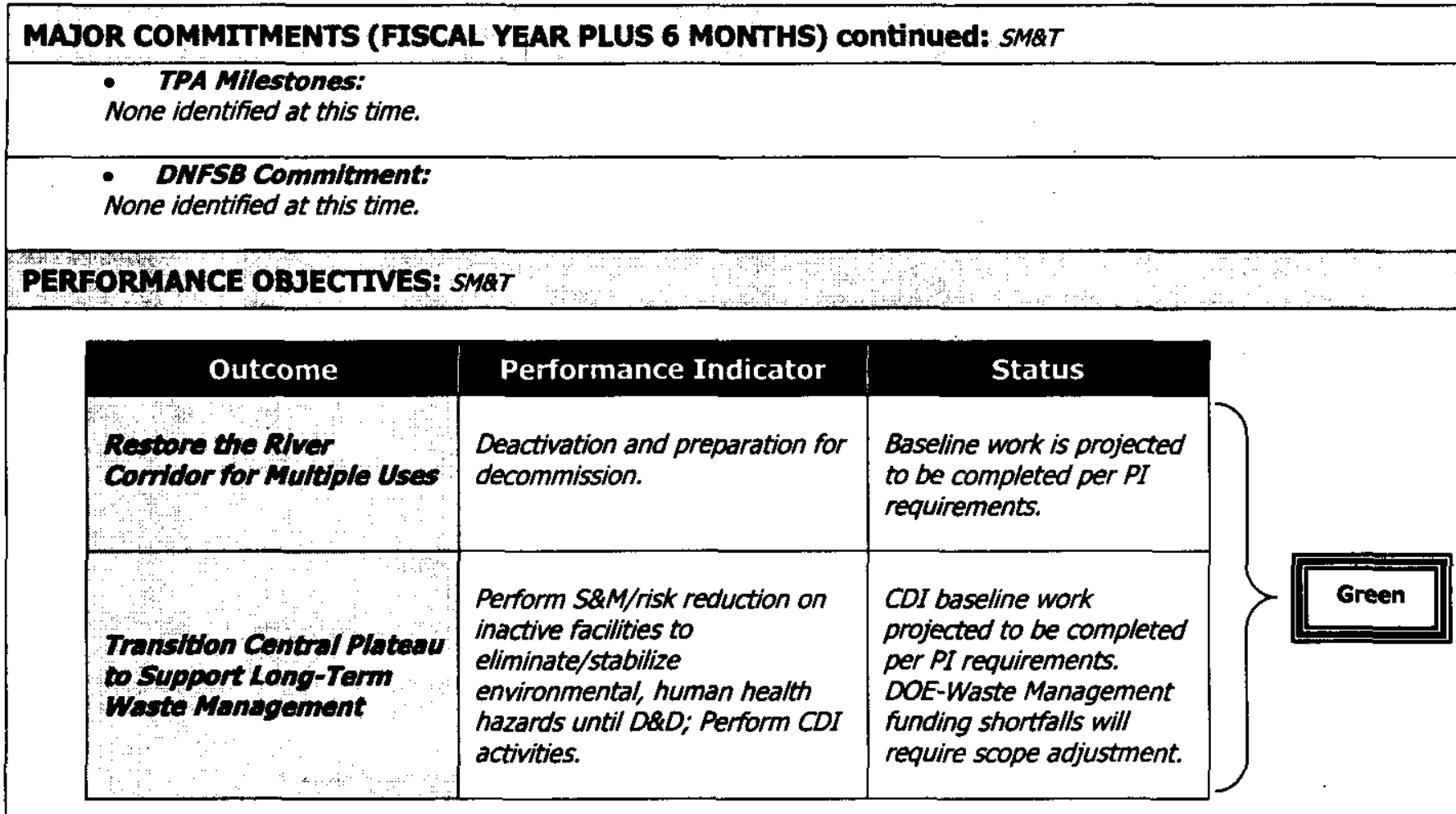

PERFORMANCE MEASURES: SMRT

None planned in FY 2000.

STRETCH AND SUPERSTRETCH GOALSI SMAT

\begin{tabular}{|c|c|c|}
\hline FY00 SM\&T "Stretch" Goals & $\begin{array}{l}\text { Scope Dollars } \\
\text { (K) }\end{array}$ & $\begin{array}{l}\text { Approved } \\
\text { BCPs (K) }\end{array}$ \\
\hline $\begin{array}{l}\text { Deactivate 183-N Water Treatment Plant } \\
\text { (Phase I) (BCP-20111) } \\
\text { Deactivate 183-N Water Treatment Plant } \\
\text { (Phase II) (BCP-20175) }\end{array}$ & $\begin{array}{l}\$ 131.0 K \\
\$ 159.0 K\end{array}$ & $\begin{array}{l}\$ 131.0 K \\
\$ 159.0 K\end{array}$ \\
\hline $\begin{array}{l}\text { Asbestas Abatement \& Repolrs (100, 200, } 8 \\
300 \text { Areas) }\end{array}$ & $\$ 470.0 K$ & $\$ 64.2 K$ \\
\hline $\begin{array}{l}\text { Complote the Cor Tectinical Work to Support } \\
\text { the Phase III Feaslbulity Study }\end{array}$ & $\$ 490.0 K$ & $\$ 0.0 K$ \\
\hline S/Total SM\&T -Facllth Transition Stretch Gaals: & $\$ 1,250.0 K$ & $\$ 354,2 K$ \\
\hline
\end{tabular}




\section{ENVIRONMENTAL MANAGEMENT PERFORMANCE REPORT ENVIRONMENTAL RESTORATION \\ AUGUST 2000}

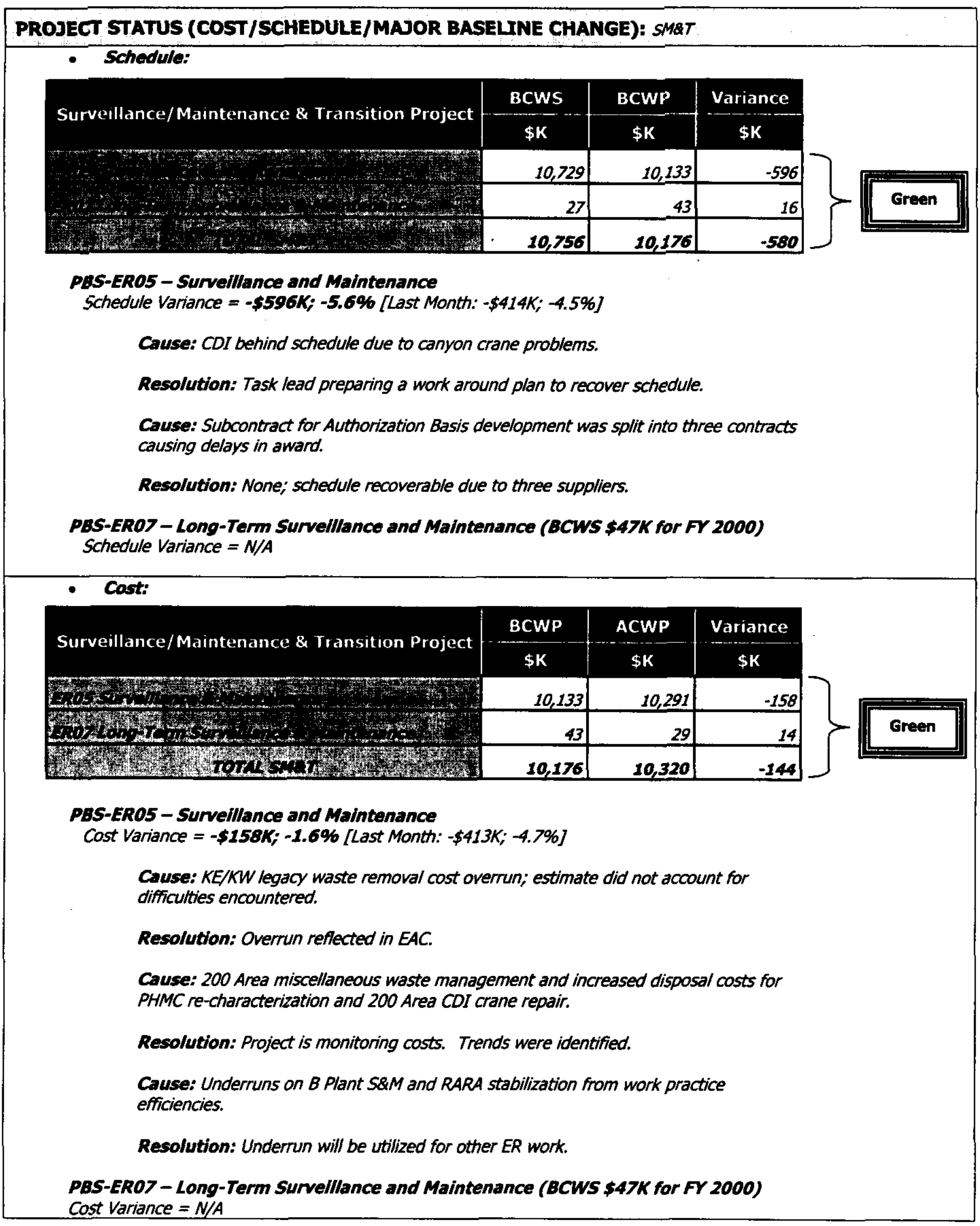

Cost Variance $=N / A$ 


\section{ENVIRONMENTAL MANAGEMENT PERFORMANCE REPORT ENVIRONMENTAL RESTORATION AUGUST 2000}

\section{REGULATORY ISSUES: SMBT}

None identified at this time.

EXTERNAL ISSUES (1.e. HAB, Congress, etc.): SM\&T

None identified at this time.

DOE-RL \& HQ ISSUES/REQUESTS (not covered elsewhere): SMRT

B Plant/PUREX Roof Funding: Ensure funding is provided by Facility Transition Project per MOUs to support roof repair commitments for B Plant and PUREX. Facilities were transitioned to ER with the commitment to fund these repairs from the releasing project.

Status: Funding for roof repairs have not been included within the current abovethe-line Integrated Priority List targets. The roof leaks based on last quarterly surveillance. There are past indications that the roofs leaks. A meeting is planned with $R L$ on August 9 to review roof issues. A letter (CCN\# 080327) was submitted to $R L$ on July 6 documenting BHI's recommendation for roof repair.

Hexone Tanks: A Notice of Correction was received from Ecology on May 26. In the notice, Ecology stated that the Hexone Tanks were inadequately inspected, and the waste designator on the tanks was not stated properly per Washington Administrative Code (WAC) 173-303, Dangerous Waste Regulations.

Status: A BCP was approved on June 5 to perform DQOs on the Hexone Tanks in FY 2000. The tank inspection frequency was changed to a daily basis for the nitrogen purge, and to a monthly basis for the purge system integrity. A response letter was submitted to RL on June 23. DQO kick-off was held on July 18.

\section{INTEGRATION ACTIVITIES: SMQT}

None identified at this time. 


\section{Pacific Northwest National Laboratory Environmental Management Performance Report}

August 2000

PREPARED FOR THE U.S. DEPARTMENT OF ENERGY, RICHLAND OPERATIONS OFFICE OFFICE OF ENVIRONMENTAL MANAGEMENT

Pacific Northwest National Laboratory

Operated for the U.S. Department of Energy by Battelle Memorial Institute 


\section{Table of Contents}

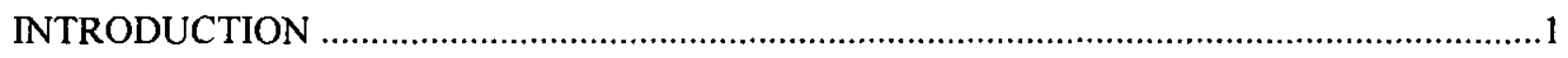

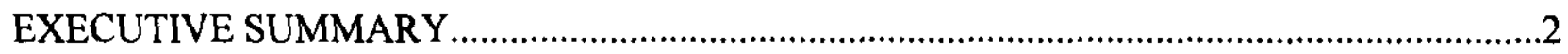

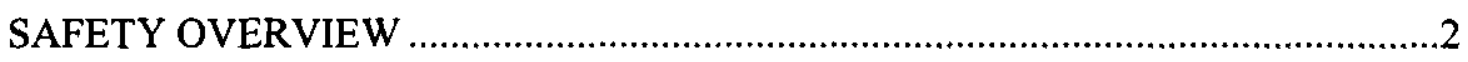

COST/SCHEDULE PERFORMANCE STOPLIGHT .........................................4

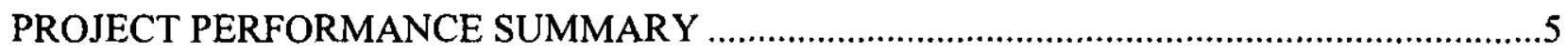

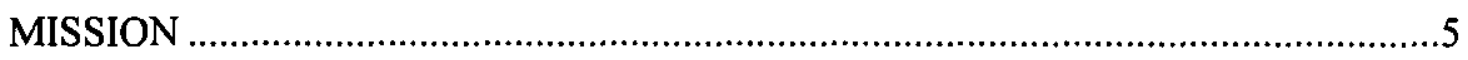

PERFORMANCE DATA AND ANALYSIS .................................................. 
$\mathrm{T}$ his document provides the Department of Energy Richland Operations Office (DOE-RL) with a report of the Pacific Northwest National Laboratory (PNNL) performance by Battelle Memorial Institute and its subcontractors.

In Section A, the Executive Summary, text and graphics report the safety metrics status for all PNNL activities. Senior management's overall performance assessment of all Environmental Management activities conducted at PNNL is presented in a stoplight chart.

Section B, Project Performance Summary, provides a brief summary of the month's performance for the PNNL lead activity, PNNL Waste Management (PBS RL-ST01). More detailed information can be found within PNNL-7911-105a, PNNL's Project Status Report for June 2000. Summary analyses pertaining to PNNL's support to other Project Baseline Summaries (PBSs) are addressed in the contractor's report having lead responsibility for that scope.

Unless otherwise noted, information in this report is current as of June 25, 2000. 
This section provides an executive-level summary of performance information and is intended to bring to management's attention that information considered to be most noteworthy. The section begins with overviews of safety, followed by a stoplight chart on overall performance.

\section{Safety Overview}

The focus of this section is on documenting trends in work-related injuries and illnesses rates. Improvements in these rates result from PNNL's continued implementation of the Integrated Environment, Safety, and Health Management System (ISMS), and the current development and implementation of the Voluntary Protection Program (VPP). Injury and illness statistical data are presented graphically in this section, followed by a summary of the completed and planned actions for the PNNL VPP.

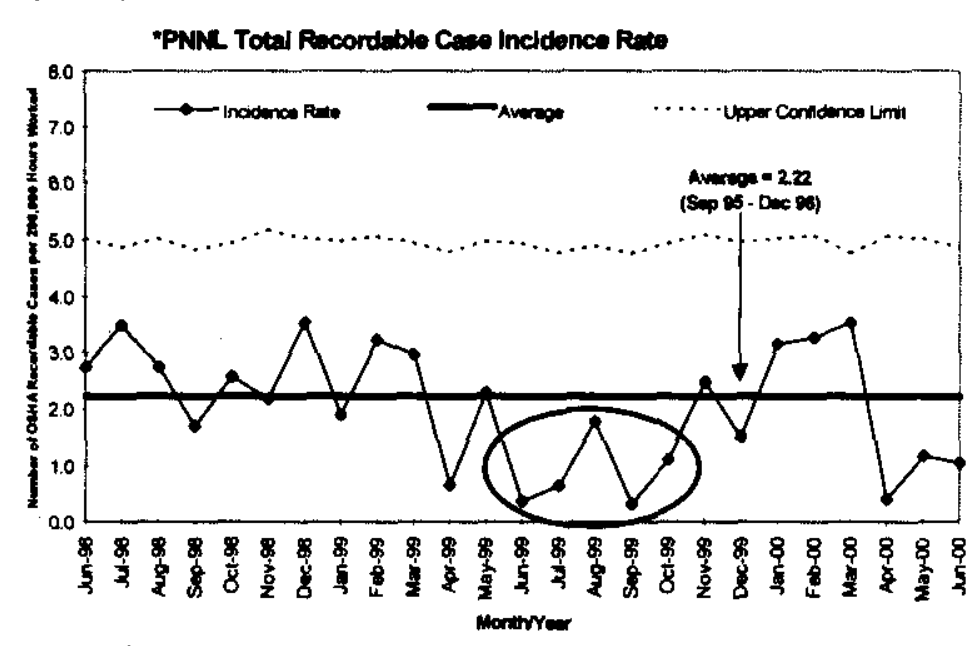

FY OORate Overview: Cumulative To Date $=1.98$ Lab Upper Limit $\leq 2.3$

This indicator has been generally stable over the long term. There was a decrease in the rates during the period of April 99 - October 99 followed by an increase back to the previous levels for the period of November 99 - March 00 followed by a return back to an expected randomly fluctuating pattern within the anticipated control limits. 
PNNL Lost Workday Case Incidence Rate

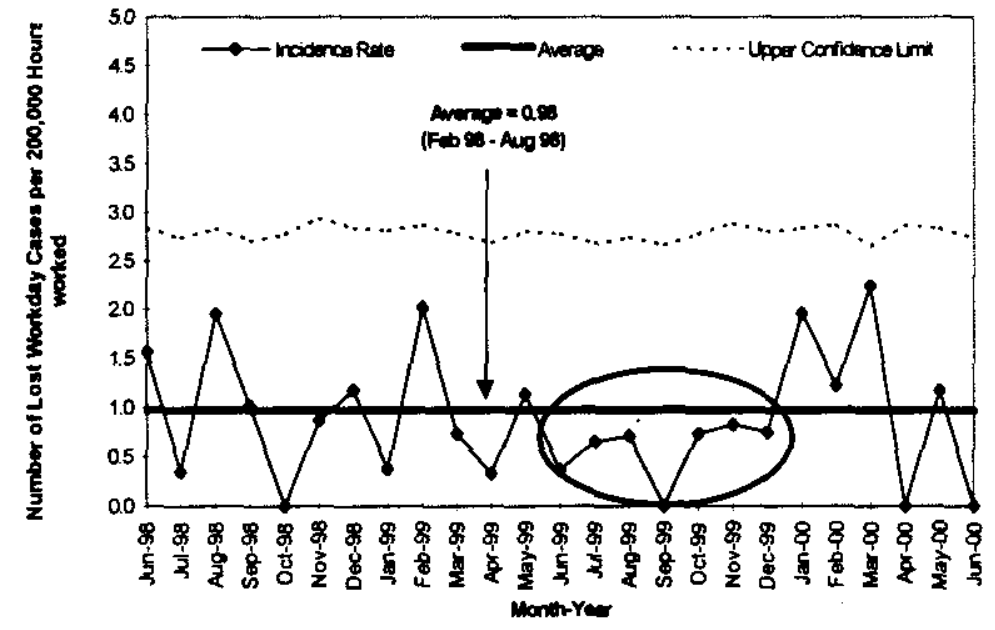

FY OORate Overview:

Cumulative To Date $=1.01$

Lab Upper Limit $\leq 1.2$

This indicator thas been generally stable over the long term. There was a temporary short-term decrease during the period of June 99 - December 99 followed by a retum back to an expected randomly fluctuating pattern within the anticipated control limits.
"PNMY Lost Workday Incidence Rate (Severity Rate)

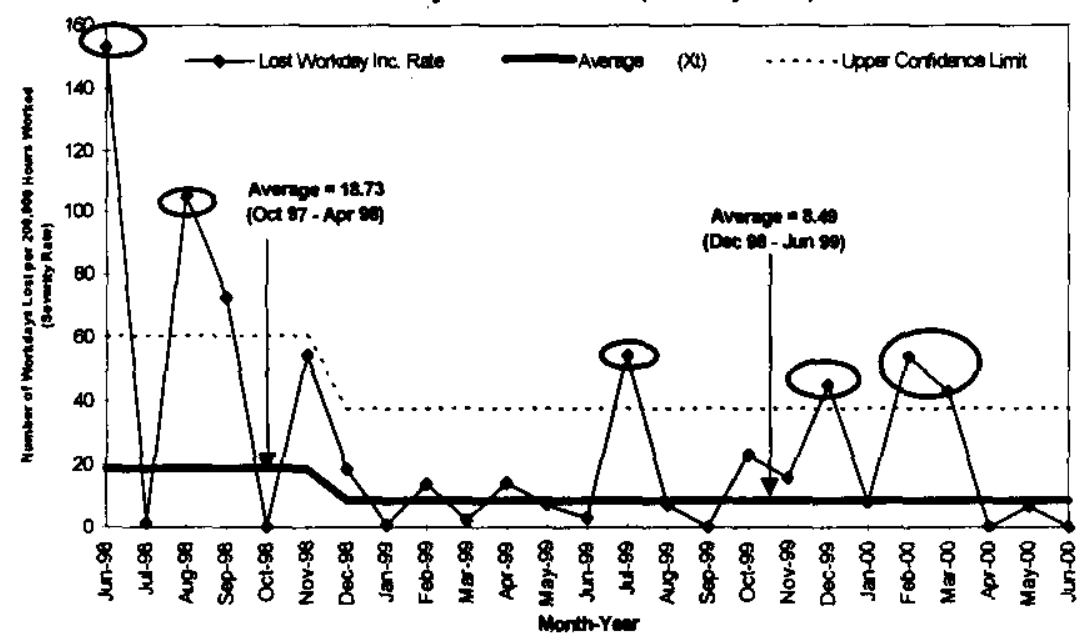

FY 00Rate Overview:

Cumulative To Date $=21.94$

Lab Upper Limit $\leq \mathbf{3 0 . 0}$

The data for the last three months have been randomly cycling within the normal anticipated control limits. The December 98 - June 99 baseline was adjusted because of further accumulation of lost workdays on cases which occurred within that time period. The months that are above the upper control limit with cases currently accurmulating lost workdays are June 98 and March 00. 


\section{Cost/Schedule Performance Stoplight}

The following rating reflects overall cost and schedule performance for activities conducted by PNNL. (Narrative not required when rating is green.)
Green: Satisfactory
Yellow: Significant improvement required
Red: Unsatisfactory 
$\mathrm{T}$ his section provides cost and schedule performance, any significant issues, and upcoming baseline change requests for the period covered. In fiscal year (FY) 2000, Battelle Memorial Institute has lead responsibility over PBS RL-ST01, PNNL Waste Management WBS 1.7.1.

\section{Mission}

WBS 1.7.1 provides PNNL with waste management services and compliant operations in support of science and technology development for the multiprogram needs of the U.S. Department of Energy (DOE) Complex. These services include;

- essential surveillance and maintenance of DOE laboratory facilities assigned to PNNL for safe containment of radioactive and hazardous materials

- infrastructure required to manage wastes and effluents currently generated at the PNNL

- operational compliance services to meet regulatory requirements and operating permits including environment, safety, and health regulations

- management of legacy wastes and contamination remaining from past PNNL research operations.

\section{Performance Data and Analysis}

As of June 25,2000 the cumulative costs are $\$ 9.5$ million with a positive cost variance of $\$ 0.4 \mathrm{M}$ and a cumulative schedule variance of negative $\$ 1.2 \mathrm{M}$. Though a majority of the schedule variance will be recovered prior to the end of the fiscal year a brief explanation of the activities that will not recover are described following the tables and chart.

\begin{tabular}{|l|c|c|c|}
\hline \multicolumn{5}{|c|}{ Cost Performance (\$M): } \\
\hline \multicolumn{5}{|c|}{ BCWP } & ACWP & Variance \\
\hline PNNL Waste Management & $\$ 9.9$ & $\$ 9.5$ & $\$ 0.4$ \\
\hline \multicolumn{5}{|c|}{ Schedule Performance (\$M): } \\
\hline & BCWP & BCWS & Variance \\
\hline PNNL Waste Management & $\$ 9.9$ & $\$ 11.2$ & $(\$ 1.2)$ \\
\hline
\end{tabular}

\section{FY 2000 Cost/Schedule Performance - All Fund Types Cumulative to Date Status - (\$000)}

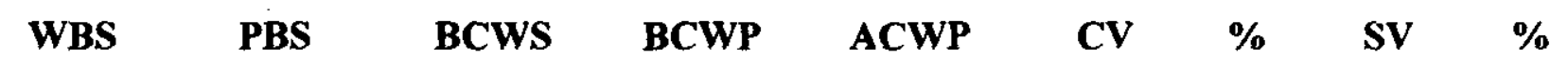

$\begin{array}{ccccccccc}1.7 .1 & \text { RL-ST01 } & \$ 11,171 & \$ 9,942 & \$ 9,529^{*} & \$ 413 & 4 & \$(1,229) & -11 \\ \begin{array}{c}\text { Total } \\ \text { * Numbers reflect PNNL only; } \$ 22 \mathrm{~K} \text { expended by }\end{array} & \begin{array}{c}\$ 11,171 \\ \$ 9,942\end{array} & \begin{array}{c}\$ 9,529^{*} \\ \text { Fluor bringing actuals to } \$ 9551 \mathrm{~K} .\end{array} & \$ 413 & 4 & \$(1,229) & -11\end{array}$


Cost / Schedule Performance Indices

FY $2000 \mathrm{Cum}$ to Date Status

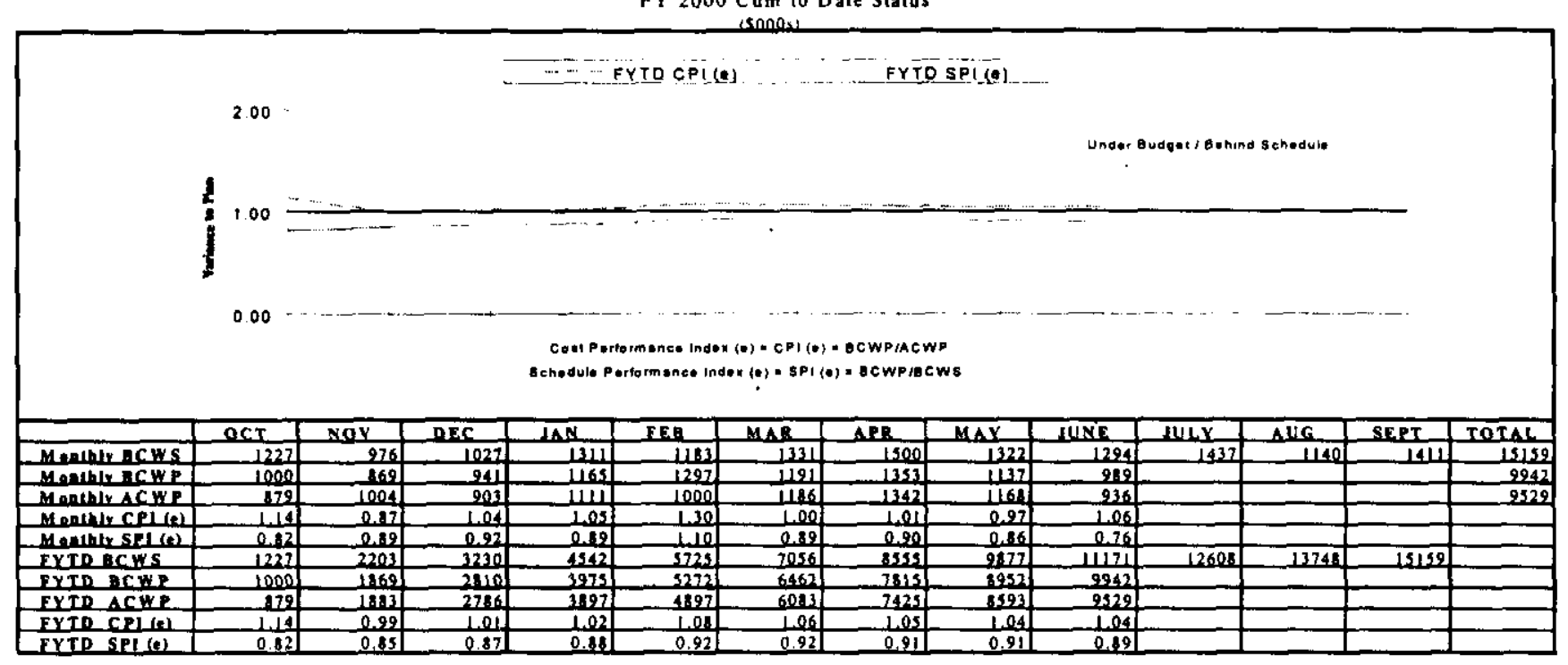

The positive cost variance of $\$ 0.4 \mathrm{M}$ results from reduced overhead rates and delayed billings. A change request was approved on July 17 to address building maintenance enhancements within Radiochemical Processing Laboratory (RPL) using programmatic underruns. These enhancements will reduce RPL annual expenditures by $\$ 25 \mathrm{~K}$. It is expected that the remaining programmatic baseline activities will be completed within the funding allocation.

The cumulative schedule variance has exceeded the reporting threshold by $1 \%$. The primary reasons for the cumulative schedule variance of negative $\$ 1.2 \mathrm{M}$ are described below:

- Difficulties in completing the final details in the high-dose waste container design delayed initiating fabrication of the drum-handling system. Delays will postpone shipments into first quarter of the next fiscal year. There is no impact associated with this delay. A baseline change request is in process to revise the schedule baseline.

- Planned LR-56 cask shipments to the 200 Area for final disposition are affected by the radioactive liquid waste system (RLWS) delay. One shipment of waste was deleted following approval and implementation of a change request. At this time, as much waste as possible is being held for the radioactive liquid waste tank (RLWT) when it comes on line. The remaining scheduled waste shipment affected by the RLWS delay may be deferred.

The integrity assessment of the RLWT-piping is currently on hold with no defined completion date. The integrity assessment was delayed because the 204-AR Facility (receiver facility) is not ready, and Pacific Northwest did not want to add any liquids to the tank to make it a radiologically controlled tank until the receiver facility is ready. The earliest the 204-AR Facility will receive waste via the LR-56 Truck is FY 2001. 


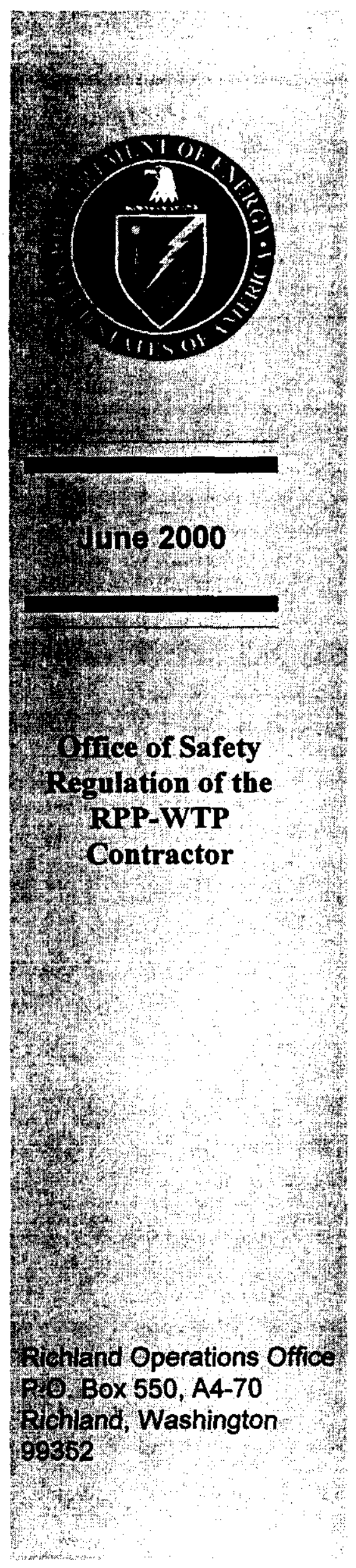

\section{Regulatory Unit}

\section{Monthly Performance Report}

\section{August 2000 \\ Environmental Management \\ Performance Report Submittal}




\section{Table of Contents}

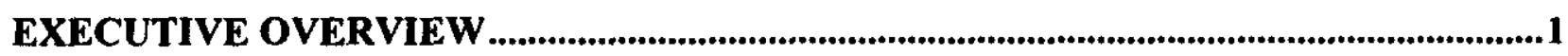

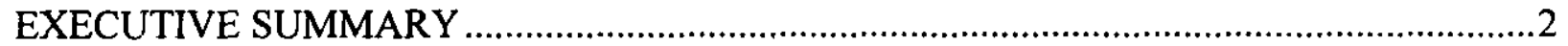

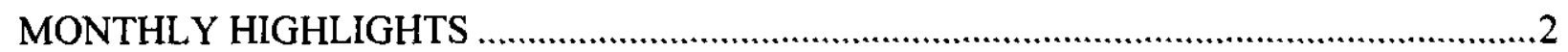

Position Paper on Interim Design Period Work Authorization ............................................ 2

Limited Construction Authorization Request Review .......................................................... 3

Review of the BNFL Non-radiological Worker Safety and Health Plan ............................... 3

Review of the BNFL QA Program and Implementation Plan............................................... 3

Review of BNFL Authorization Basis Amendment Requests .............................................. 3

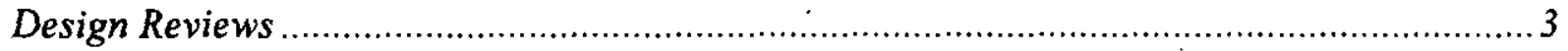

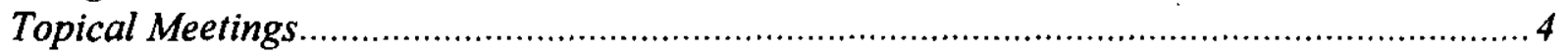

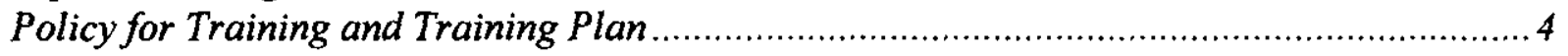

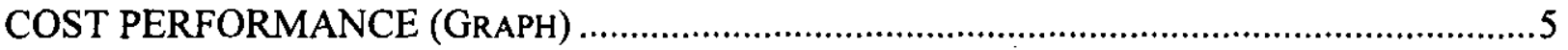

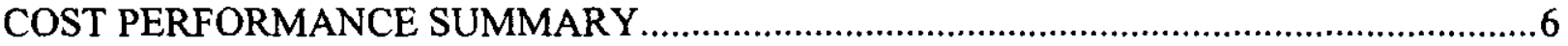

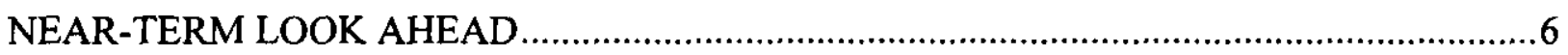

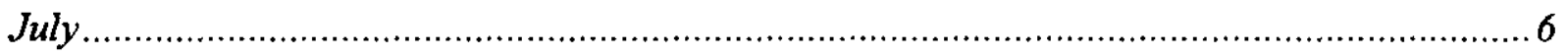

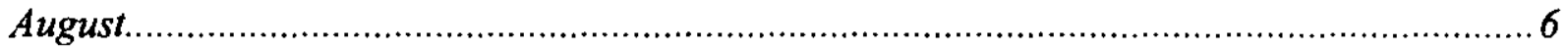

September

PROGRAM PERFORMANCE OVERVIEW …….............................................................

PERFORMANCE SUMMARY (ChART) - Program DiRection AND PROGRAM SUPPORT .......8

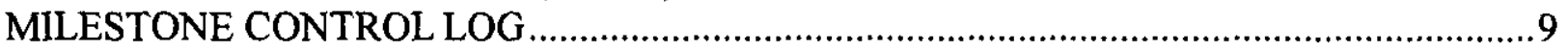

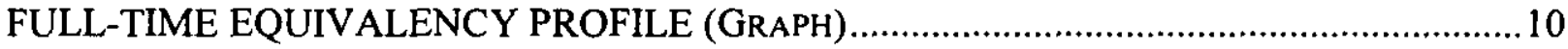

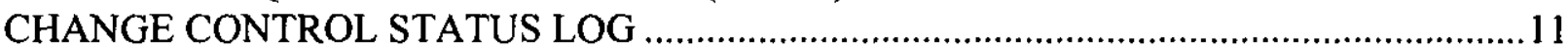




\section{EXECUTIVE OVERVIEW}




\section{EXECUTIVE SUMMARY}

In June 2000, DOE issued a notice of termination to BNFL Inc. (BNFL) for all work associated with Contract DE-AC27-96RL13308. The Department plans to transition the ongoing workscope to $\mathrm{CH} 2 \mathrm{M}$ Hill Hanford Group, Inc. (CHG) until the new design and construct contractor is in place. In the interim, the Regulatory Unit (RU) is meeting once a week with BNFL, CHG, and ORP to assure an effective and efficient transition of regulatory matters. These transition meetings will continue until the contract termination date of July $28,2000$.

Termination of the BNFL contract has impacted all in-progress RU review activities. The RU generated a list of preferred activities for BNFL to complete before the July 28,2000 , termination date; however, BNFL's current interpretation of the notice of termination permits the performance of termination activities only. To facilitate an efficient and effective transition, the RU has also provided the list to $\mathrm{CHG}$ for workscope costing and planning.

To conduct the transition of regulatory activities efficiently and effectively with CHG, the RU provided CHG with RL/REG-2000-20, Regulatory Unit Position on Important to Safety Work Authorization for the RPP-WTP Interim Design Period. In keeping with the EM-1 mandate that the independent role of the RU be incorporated in the bridging contract and the RFP, the Regulatory Official requested that ORP provide the RU with the appropriate contractual standing with $\mathrm{CHG}$ to provide an authorized mechanism for the RU to regulate safety activities. As of July 13, 2000, ORP has not provided the RU with the requested contract standing. The RU plans to continue to communicate with $\mathrm{CHG}$, until this issue is resolved with ORP.

Fiscal year-to-date efficiencies, work slowdowns and deferrals have resulted in a forecast underrun of approximately $\$ 1 \mathrm{M}$ to the current budget. Of this underrun $\$ 750 \mathrm{~K}$ is a result of efficiencies and is being made available for reprogramming to support other RL site priorities. A Class I change request will be processed to formally document these baseline changes.

Major RU activities during June are detailed below.

\section{MONTHLY HIGHLIGHTS}

\section{Position Paper on Interim Design Period Work Authorization}

Upon termination of the privatization contract, work may continue on River Protection Project Waste Treatment Plant (RPP-WTP) design during an interim design phase until such time that a new design and construction contract is in place. The interim design phase work, if any, will be performed by CHG. EM-1 has provided direction to maintain the RPP-WTP regulatory and authorization basis through contract transitions. In keeping with this direction, the RU developed RL/REG-2000-20 This paper describes revision of the authorization basis to accommodate important-to-safety RPP-WTP work performed by $\mathrm{CHG}$, and the authorization of $\mathrm{CHG}$ to perform that work. 


\section{Limited Construction Authorization Request Review}

The RU completed its acceptability review of the BNFL Limited Construction Authorization Request (LCAR) for the RPP-WTP, which was submitted on June 26, 2000. To reach a determination on continuing with a detailed review, RU reviewers assessed the submittal against the criteria of the LCAR Review Guidance that was previously provided to and commented on by BNFL. The RU determined that the LCAR was not acceptable for detailed review. In general, the RU found that only limited additional information was necessary for the RU to continue its review. Because BNFL does not plan to resubmit the LCAR prior to termination, the RU will conduct a detailed review of those parts of the LCAR that were acceptable for detailed review and provide $\mathrm{CHG}$ with questions and comments for their consideration in resubmitting the LCAR.

\section{Review of the BNFL Non-radiological Worker Safety and Health Plan}

The RU completed its review of this BNFL document and prepared a draft assessment report, RL/REG-2000-21, Regulatory Unit Assessment of the Non-radiological Worker Safety and Health Plan, which defines the BNFL construction safety program. The Report reflects the Contractor's response to two sets of questions from the RU. The Report will be issued in July for BNFL and public comment. BNFL plans to provide CHG with the Non-radiological Worker Safety and Health Plan and the $R U$ evaluation report during the transition.

\section{Review of the BNFL QA Program and Implementation Plan}

On June 26, 2000, BNFL submitted to the RU for review and approval its Quality Assurance Program and Implementation Plan (QAPIP) for Design and Construction. The RU completed its acceptability review of the Plan and determined the Plan was acceptable for detailed review. The RU was conducting its detailed review of the QAPIP when the termination of the BNFL Contract was announced. The RU plans to complete its review and provide its questions to BNFL prior to termination on July 28, 2000. BNFL will provide CHG with the Plan; the RU questions on the Plan, and the RU draft evaluation report as turnover documents. The Plan has been placed on the RU Website.

\section{Review of BNFL Authorization Basis Amendment Requests}

At the time of the notice of termination, the RU was reviewing 13 authorization basis amendment requests (ABARs). Several of the ABARs will be approved and the remainder will require additional information and revision. BNFL plans to provide $\mathrm{CHG}$ with the RU comments on the ABARs as part of the transition documents.

\section{Design Reviews}

The RU observed $11 \mathrm{BNFL}$ design reviews in June. The design media reviewed during June was more developed than that delivered to ORP on April 24 as part of the Part B-1 Contract deliverables. For example, some piping and instrumentation diagrams included control logic and identification of what instruments were classified as important to safety. Due to termination of the Contract, BNFL has discontinued the design reviews. 


\section{Topical Meetings}

The June Topical Meeting was held to disposition issues remaining open from previous meetings. In preparation for this meeting, the RU identified 15 priority issues that required resolution to expedite its review of the Construction Authorization Request. BNFL provided status on all 15 issues and addressed in detail the issues of hydrogen monitoring, cesium storage tank cooling, chemical hazards evaluation, and standards selection. Due to time constraints, BNFL's presentation on the control strategy for nitrogen oxide accumulation in the low activity waste melter and its associated off-gas system were rescheduled for July 13,2000. However, due to the notice of termination, BNFL has cancelled this meeting and the Topical Meeting scheduled in July 2000.

\section{Policy for Training and Training Plan}

The RU completed an update to RL/REG-97-07, Regulatory Unit Policy for Training and Training Plan. The RU Training Policy emphasizes competence to perform assigned duties and a systematic approach to training (SAT) to maintain such competence. The training framework is based on conformance with the internal processes of $R L$. 

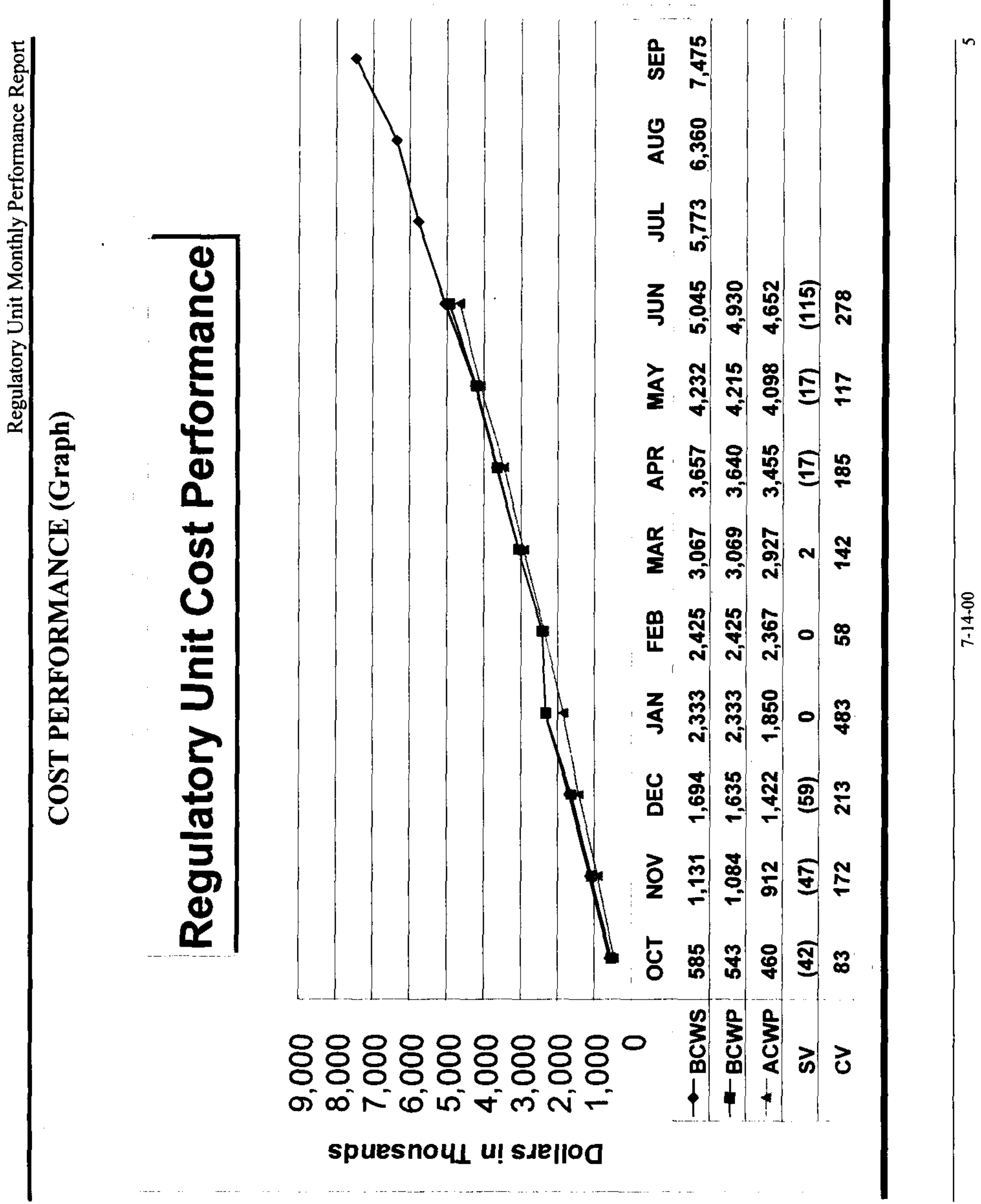


\section{COST PERFORMANCE SUMMARY}

The fiscal year-to-date performance through June reflects a favorable cost variance of $\$ 278 \mathrm{~K}$ and an unfavorable schedule variance of $\$ 115 \mathrm{~K}$. The favorable cost variance is a result of lower than anticipated costs associated with observing Design Reviews, providing training for RU staff, development of CAR review handbooks, and writing inspection procedures. The unfavorable schedule variance is primarily due to BNFL withdrawing their Radiation Protection Program (RPP), which was determined to be unacceptable by the RU after a one-week acceptability review.

\section{NEAR-TERM LOOK AHEAD}

The termination of the BNFL contract impacted a majority of FY 2000 RU work activities. Many of these activities, as shown below, had major milestones associated with their completion dates. Until a new baseline is approved, these dates will be shown as "TBD".

July

Planned Due Date

- Begin review of Contractor's resubmitted RPP for Design and Construction TBD

- Conduct QA Inspection

- Issue AR on BNFL Non-Radiological Worker Safety and Health Plan

7-21-00

- Conduct Topical Meeting on Seismic PRA

TBD

- Issue SAP Review Handbook

$7-31-00$

August

- Conduct ALARA Inspection

- Present $15^{\text {th }}$ Quarterly Briefing to Headquarters

- Issue QA Inspection Report

TBD

- Issue ER on BNFL QAPIP

September

- Commence Review of BNFL ISMP Revision

TBD

- Issue ALARA Inspection Report

TBD

- Conduct Configuration Management Inspection

TBD

- Commence Review of BNFL HAR Revision

TBD

- Issue CAR Review Handbook

TBD

- Issue FY 2001 Program Management Plan

9-29-00 


\section{PROGRAM PERFORMANCE OVERVIEW}




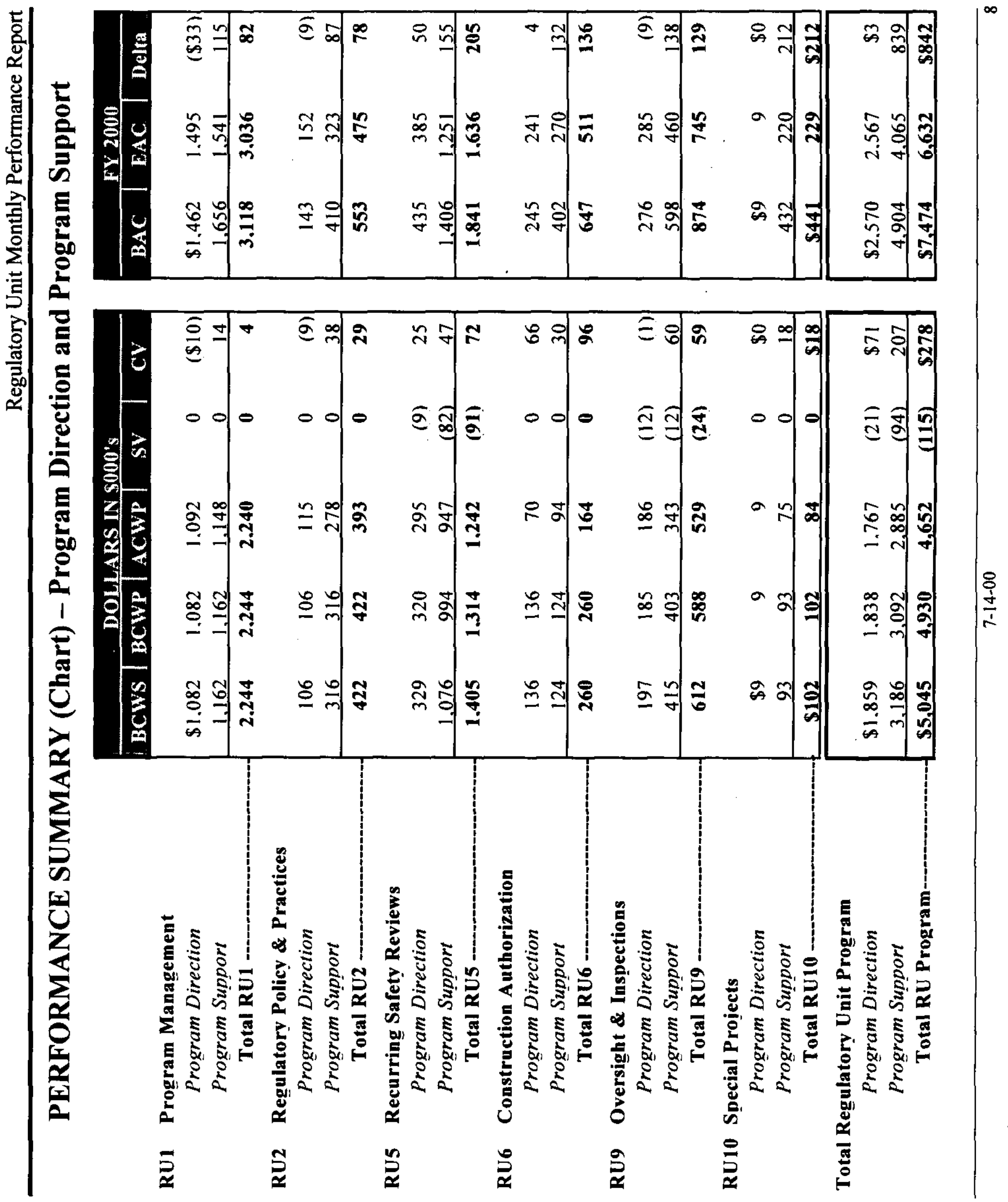




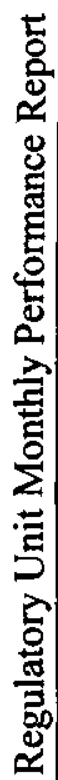

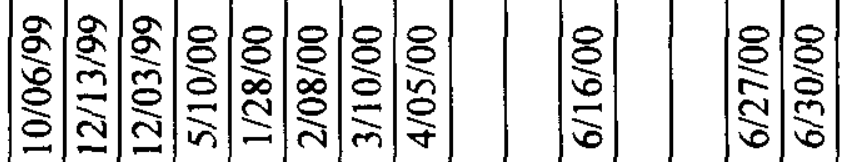

$\frac{\wp}{\infty}$

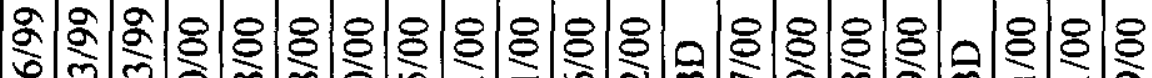
ஓ)

w

85

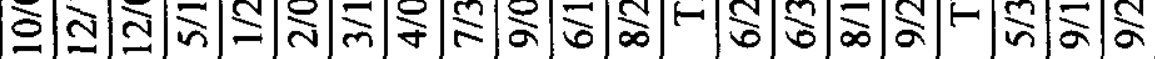

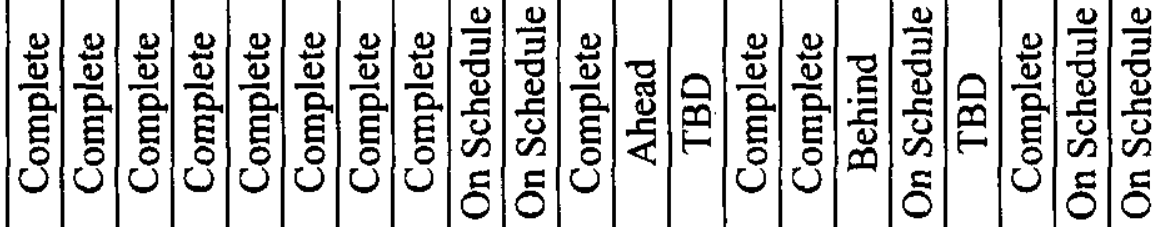

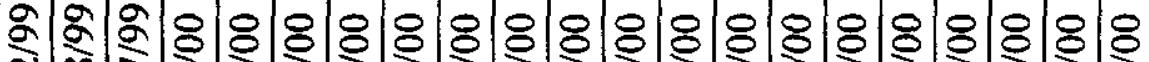

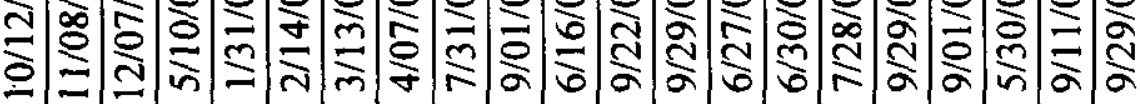

$8 \%$

40

i

$\leq$

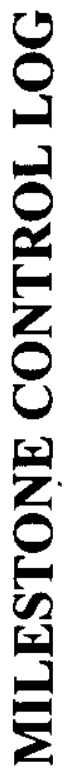

(4)

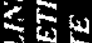

둥응

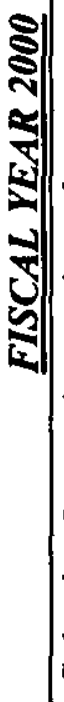

궁

范

$\stackrel{2}{2} \stackrel{2}{2}$

들 흘

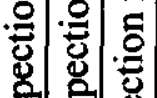

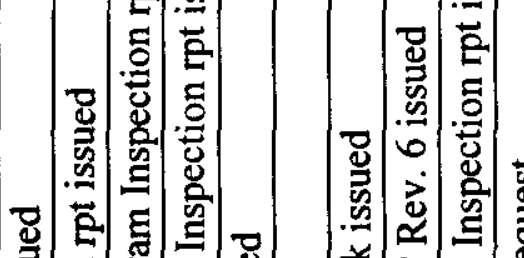

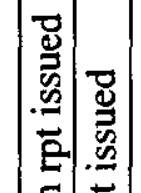

密 总

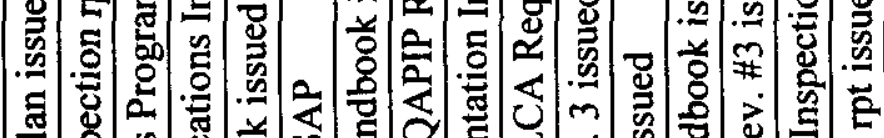

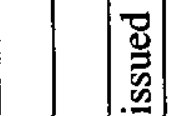

㲅

믹

8

a.

电.

a

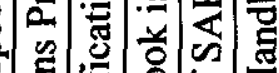

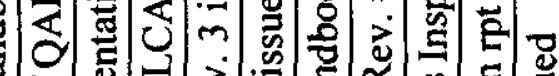

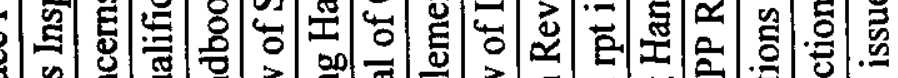

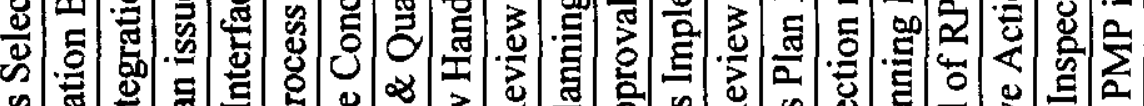

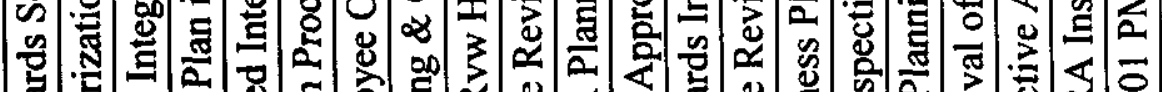

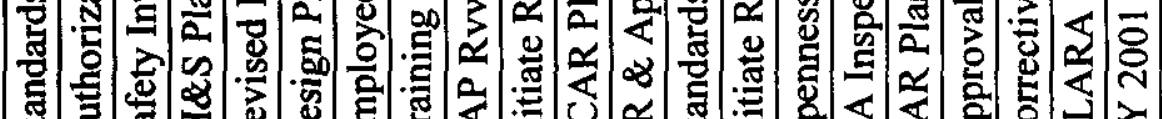

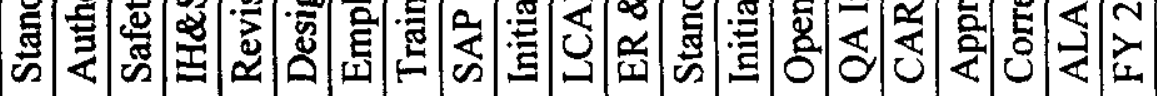

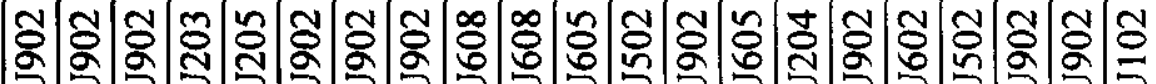

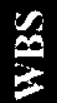

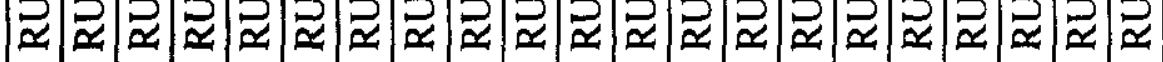

苫 官

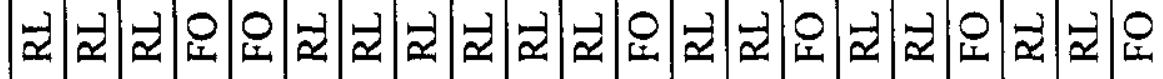



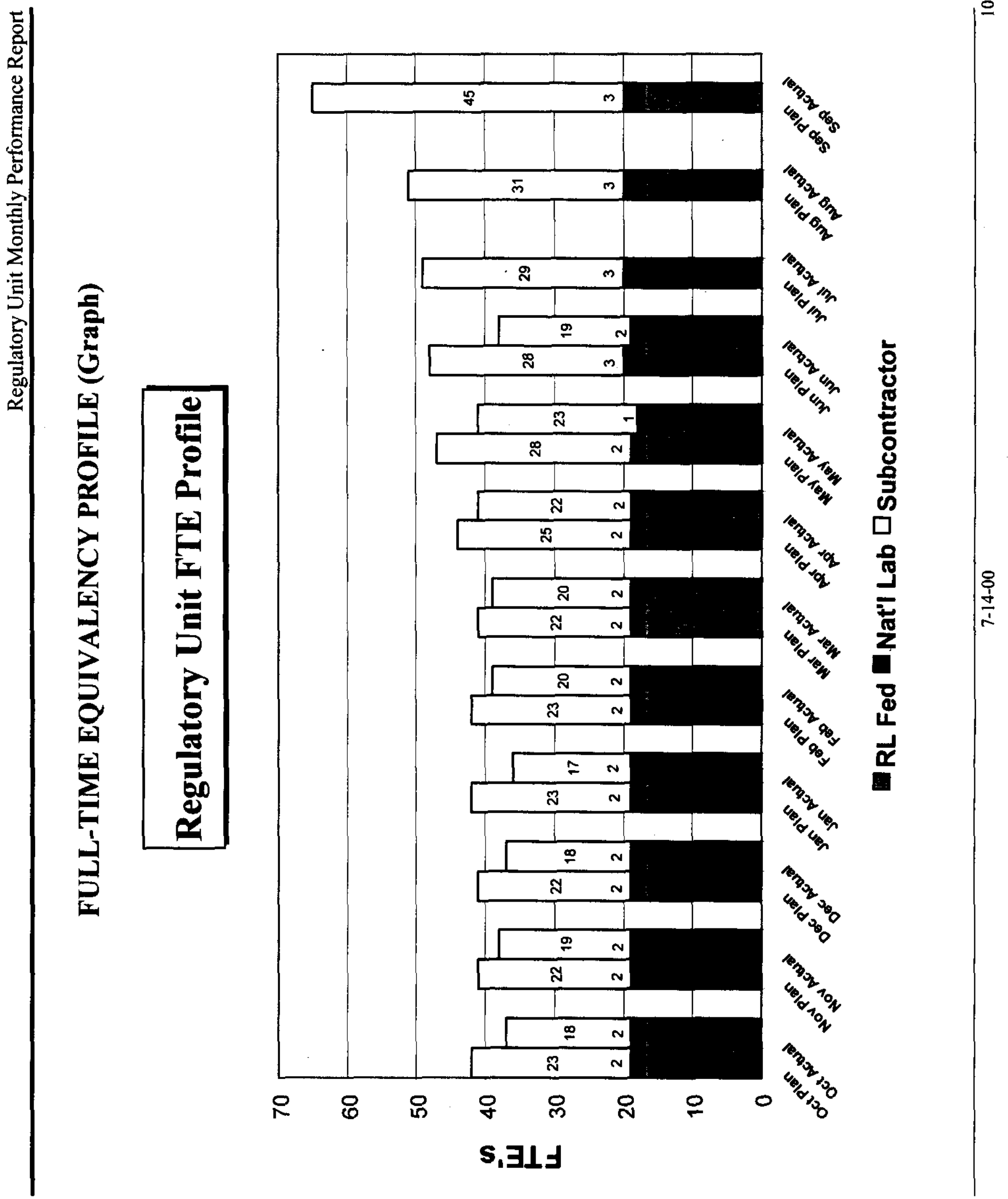

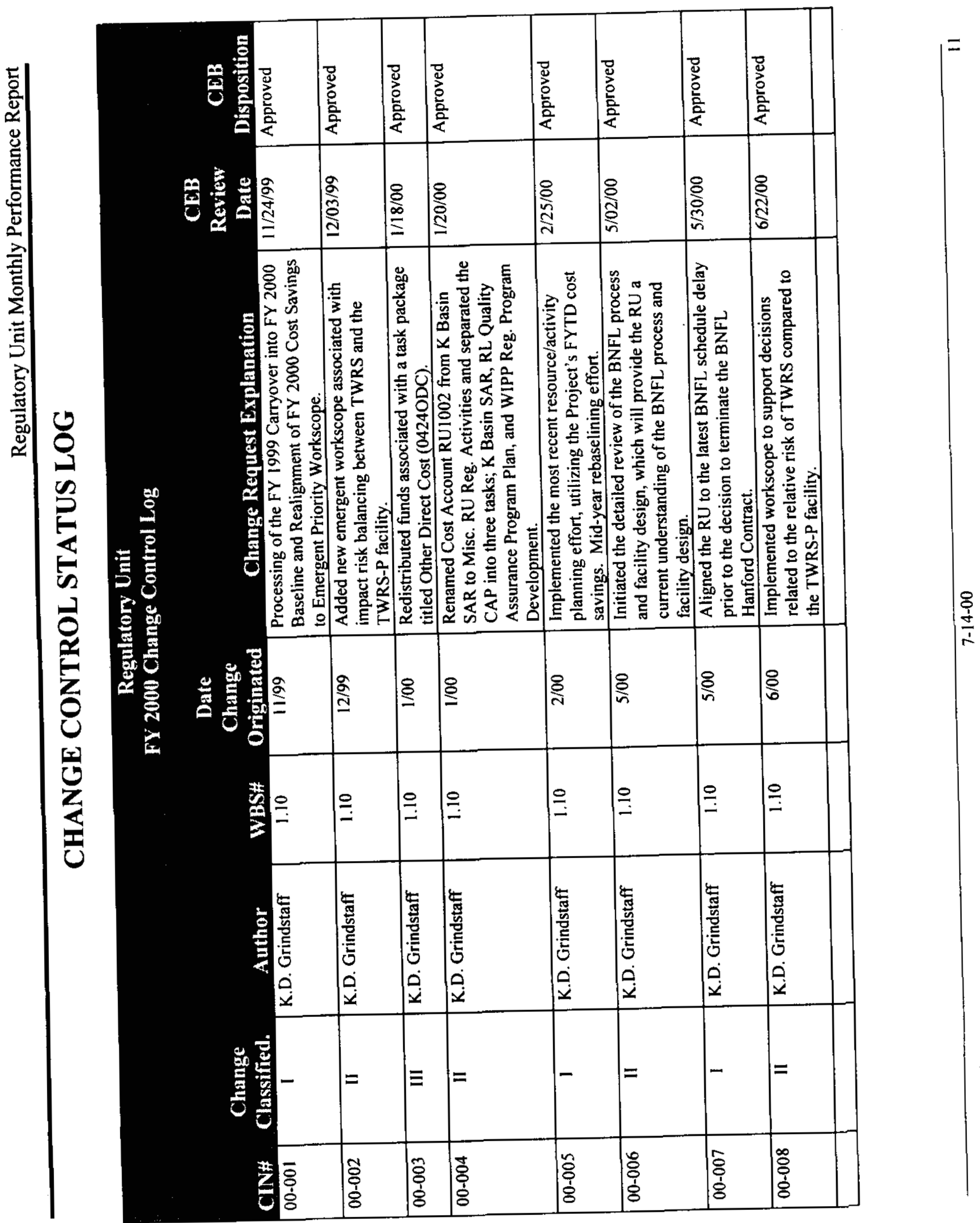


\section{GLOSSARY}

Actual cost of work performed (ACWP): The actual cost incurred and applied or distributed for the work performed within a given time period. It includes all labor categories, material, any other direct costs, subcontract work, and function overhead.

Approved baseline: The budget authorized to perform the workscope that has been agreed upon by the customer and the contractor(s). It is portrayed in the Multi-Year Work Plan with all approved changes. This baseline may or may not be fully funded, and could be more or less than the compliance baseline.

Budget at completion (BAC): The sum of budgets established to complete a program and/or project or any component of a program and/or project.

Budgeted cost of work performed (BCWP): The value for completed work measured in terms of the planned budget for that work. It is synonymous with earned value.

Budgeted cost of work scheduled (BCWS): The time-phased budgeted value of work scheduled to be accomplished over a given time period. The BCWS for a total cost account through its entire period of performance is equal to the $\mathrm{BAC}$ for the cost account.

Carryover Workscope: The estimated dollar amount of the workscope that was not completed during the fiscal year and which will be carried over and completed in the next fiscal year.

Compliance baseline: The budget that is required to perform the workscope necessary to be in compliance with State and Federal regulations, enforceable agreement milestones, and DNFSB milestones. The level of activity required to be in compliance assumes sufficient funding. Note: Because approved baselines are considered to be compliant, this column will likely be eliminated.

Contract Inherited: The assumed budget for the planned scope of work at the time a new contract is signed by the company responsible for performing the work.

Cost variance (CV): The difference between $B C W P$ and $A C W P(C V=B C W P-A C W P)$. At any time, it shows whether the work actually performed has cost more or less than the amount budgeted for the same work.

Cost Performance Indicator (CPI): The CPI is the ratio of BCWP to ACWP, or (BCWP/ACWP).

Earned value (EV): The periodic, consistent, and objective measurement of work performed in terms of the budget planned for that work. The EV is synonymous with the BCWP and it is compared to the BCWS to obtain schedule performance and to the ACWP to obtain cost performance. 


\section{GLOSSARY (CONTINUED)}

Estimate at completion (EAC): Cost allocated to the work breakdown structure element to date, plus the estimate of costs for authorized work remaining. Authorized work remaining includes any undistributed budget.

Fiscal Year Spending Forecast (FYSF): The estimated total that will be spent from October through September (current Fiscal Year).

Funding carryover and new Budget Authorization (BA): This funding represents both the funding allocated to perform workscope planned in the prior fiscal year, not completed, and approved to be performed in the current fiscal year, as well as new BA to perform the approved baseline workscope.

Funding target: The level of funding that is anticipated (as a result of the Integrated Priority List process) in a given Fiscal Year based on an assumed funding level for the Site.

Multi-Year Work Plan - 10/1/XX: The Project's approved cost/schedule/technical baseline at the beginning of the fiscal year.

Project Execution Module (PEM): The Project Execution Module (PEM) of the Integrated Planning, Accountability, and Budgeting System-Information System (IPABS-IS) replaces the Progress Tracking System (PTS) as EM Headquarters' centralized system for reporting financial, milestone, performance, and other execution-year information for PBSs, sub-PBSs, TTPs, and line item construction projects. In addition, this module collects mid-year and year-end actual performance information against the agreed upon management commitments for the current execution year.

Schedule Performance Indicator (SPI): The SPI is the ratio of BCWP to BCWS, or (BCWP/BCWS).

Schedule variance (SV): The difference between BCWP and BCWS (SV = BCWP - BCWS). At any time, or for a given period of time, it represents the difference between the planned dollar value of work actually accomplished and the value of the work scheduled to be accomplished.

Work breakdown structure (WBS): A product-oriented family tree division of real estate, hardware, software, services, and data products that organize, define, and display all of the work to be performed in accomplishing the program and/or project objectives. 